University of Nebraska - Lincoln

DigitalCommons@University of Nebraska - Lincoln

January 2008

\title{
American Indian treaties in the Courts of Claims: A guide to treaty citations from opinions of the United States Courts of Claims
}

Charles D. Bernholz

University of Nebraska-Lincoln, cbernholz2@unl.edu

Robert Weiner

Syracuse University College of Law, rjweiner@law.syr.edu

Follow this and additional works at: https://digitalcommons.unl.edu/libraryscience

Part of the Library and Information Science Commons

Bernholz, Charles D. and Weiner, Robert, "American Indian treaties in the Courts of Claims: A guide to treaty citations from opinions of the United States Courts of Claims" (2008). Faculty Publications, UNL Libraries. 148.

https://digitalcommons.unl.edu/libraryscience/148

This Article is brought to you for free and open access by the Libraries at University of Nebraska-Lincoln at DigitalCommons@University of Nebraska - Lincoln. It has been accepted for inclusion in Faculty Publications, UNL Libraries by an authorized administrator of DigitalCommons@University of Nebraska - Lincoln. 
Published in Government Information Quarterly 25 (2008), pp. 313-327;

doi:10.1016/j.giq.2006.07.015 Copyright (C) 2006 Elsevier Inc. Used by permission.

http://www.sciencedirect.com/science/journal/0740624X

Published online May 8, 2007.

\title{
American Indian treaties in the Courts of Claims: A guide to treaty citations from opinions of the United States Courts of Claims
}

\author{
Charles D. Bernholz ${ }^{\mathrm{a}, *}$ and Robert J. Weiner Jr. ${ }^{\mathrm{b}, 1}$ \\ ${ }^{a}$ Love Memorial Library, University of Nebraska-Lincoln, \\ Lincoln, NE 68588, USA \\ ${ }^{\mathrm{b}} \mathrm{H}$. Douglas Barclay Law Library, Syracuse University College of Law, \\ Syracuse, NY 13244, USA \\ * Corresponding author. fax: 402 472-5131; email: cbernholz2@unl.edu
}

\begin{abstract}
Since 1855, the federal Courts of Claims have provided relief for citizens in cases against the United States. President Abraham Lincoln, in his first annual message in 1861, declared his support for such a process: "It is as much the duty of government to render prompt justice against itself, in favor of citizens, as it is to administer the same between private individuals" [Message of the President. (1862). Appendix to The Congressional Globe, 37th Congress, $2 \mathrm{~d}$ session, 3 December 1861, p. 2]. Among the Courts' cases, 240 of 375 recognized American Indian treaties have been cited 992 times in 342 opinions between the years 1884 and 2004 . The reliance upon so many of these instruments - more than the number referenced before the United States Supreme Court-demonstrates their importance within the federal courts.
\end{abstract}

Keywords: American Indian treaties, United States Court of Claims

The Court of Claims, and successor courts, have served as the primary judicial arena for "all petitions and bills praying or providing for the satisfaction of private claims

${ }^{1}$ Fax: 315 443-9567; email: rjweiner@law.syr.edu 
against the Government, founded upon any law of Congress, or upon any regulation of an executive department, or upon any contract, express or implied, with the Government of the United States" (An act to amend "An act to establish a court for the investigation of claims against the United States," 1863). This mandate was an extension of the initial act (An act to establish a court for the investigation of claims against the United States, 1855). Shimomura (1985) has shown that the bases for the Court of Claims reach back to the legislative traditions in 17th century England and - regardless of whether or not the authority orientation evolved into a more judiciary one - the primary concern was for an individual "to be able to petition his government for a redress of [his] grievance" (p. 626). ${ }^{2}$ This article will enumerate, in part, the grievances brought before the Court by Indian tribes against the federal government, in claims that were based upon treaty parameters.

Congress had suffered through the punishing task of legislatively addressing the private claims that had choked it since the beginning of the Nation: all 900+ pages of volume 6 of the Statutes at Large are filled with such claims or requests for special status between the years 1789 and 1845 (Peters, 1862) tackling everything from indemnification for ransom (6 Stat. 54; 26 March 1804); to two requests for military medals for crew members of the USS Constitution and of the USS Hornet for their captures of British vessels (6 Stat. 181; 22 February 1816); to the duty-free importation of iron steamboats (6 Stat. 739; 7 July 1838). ${ }^{3}$

It was precisely these types of encumbering issues under a legislative model that were reported by the Committee of Claims (Board of Claims, 1838) to demonstrate the everincreasing caseload and its impediment upon Congress. These points were reiterated in a report 10 years later (Claims Against the United States, 1848), but even with these additional difficulties, Congress remained opposed to relinquishing control of these financial matters. ${ }^{4}$ Further, various opportunities for exploitation had developed over the years, to such an extent that the Senate created another committee to "inquire into abuses, bribery, or fraud, in the prosecution of claims before Congress" (Abuses in the Prosecution of Claims, 1852, p. 2100). Richardson (1885) provided a particularly rich description of the evolution of the Court up to 1885 .

In 1855, the foundation for the Court of Claims was created (An act to establish a court for the investigation of claims against the United States, 1855), although the precise mechanics of operating as a true court or as an advisory panel for the Congress remained obscure, and in the following years, Congress - while being advised by the new Courtremained mired in the responsibilities that adhered to a legislative model for claims adjudication. The 1863 Act (An act to amend "An act to establish a court for the investigation of

${ }^{2}$ The article by Shimomura provides an exceptional history of the claims process in both England and the United States.

${ }^{3}$ The first entry in this volume (6 Stat. 1; 29 September 1789) allowed the payment at the rank of Captain in the Army to Baron de Glaubeck for his Revolutionary War service, while the final entry in the compilation (6 Stat. 942; 3 March 1845) sustained the payment of annuities due to a number of Miami Indian tribe members.

${ }^{4}$ The final remarks in the report included the statement that: "Some of the members of the committee suggested the expediency of a reference of the whole matter to the court of the United States, under such regulations as might be adopted by Congress, but the committee did not think that all the subjects brought to the consideration of Congress were proper subjects of decision by judicial tribunals" (Claims Against the United States, 1848, p. 8; emphasis added). 
claims against the United States") moved partially towards a judicial model by administering contract and selected federal claims (Sections 2 and 3). As a further restriction on the latitude afforded this new court/committee, Section 14 (12 Stat. 765, 768) stated: "That no money shall be paid out of the treasury for any claim passed upon by the court of claims till after an appropriation therefor[e] shall be estimated for by the Secretary of the Treasury," but this caused difficulties, including the rejection by the Supreme Court to hear an appeal of a Court of Claims case for want of appellate jurisdiction (Gordon v. United States, 1864). This Treasury restriction was repealed in 1866 (An act in relation to the Court of Claims), and the Court of Claims commenced full operations as a court to hear cases that could be appealed to the United States Supreme Court. ${ }^{5}$ This was followed in 1887 with final, full approval for the Court of Claims to adjudicate all claims against the United States, except for pension or tort claims, or for claims resulting from the Civil War (An act to provide for the bringing of suits against the government of the United States, 1887).

The findings in the United States v. Realty Co. (1896) case before the Supreme Court had far-reaching effects. In that opinion, it was determined that both legal as well as moral claims against the United States were recoverable though Congress and, if need be, through the courts. This eased addressing issues that had separated Indian tribes from the federal government, but as Bradford (2002) has shown, the process of reparations for past events can be less than straightforward. ${ }^{6}$

The range of legal topics had been expanded when "An act to provide for the adjudication and payment of claims arising from Indian depredations" was made into law in $1891 .^{7}$ Tribes had been restricted since 1863 from filing suit because the Act that adjusted the establishment of the Court of Claims also constrained future applications. ${ }^{8}$ Claims could be raised, but before 1946, Congress was required to authorize the Court of Claims

${ }^{5}$ See United States v. Klein (1871) for remarks upon this jurisdiction, given the repeal of Section 14.

${ }^{6}$ The perceived restriction that Indian tribes lacked their own capability to bring suit without relying upon the United States as their guardian was removed only in 1966 with the addition of $\S 1362$ to the United States Code: "The district courts shall have original jurisdiction of all civil actions, brought by any Indian tribe or band with a governing body duly recognized by the secretary of the Interior, wherein the matter in controversy arises under the Constitution, laws, or treaties of the United States" (80 Stat. 880; emphasis added).

${ }^{7}$ Skogen (1996) presented the entire history of depredation claims in the United States, and see Toelle (1926), who declared that "litigation under this heading may perhaps be regarded as only quasi-international" (p. 682, emphasis added).

${ }^{8}$ Section 9 of the Act stated: "That the jurisdiction of the said court shall not extend to or include any claim against the Government not pending in said court on the first day of December, Anno Domini eighteen hundred and sixty-two, growing out of or dependent on any treaty stipulation entered into with foreign nations or with Indian Tribes" (12 Stat. 765, 767). Newton (1992, p. 770) noted that this focus on "any treaty stipulation" inhibited efforts "to permit claims by tribes not based on treaties to proceed in the Court of Claims" (emphasis added).

${ }^{9}$ Richardson (1885), writing in 1885 as the Chief Justice of the Court of Claims, commented that "[i]n cases growing out of treaties with foreign nations or Indian tribes, not now within the jurisdiction of the court, and other like cases, Congress may refer the matters in controversy by special acts, as it frequently has done, for final adjudication and judgment" (pp. 12-13, emphasis added). Barney (1955) identified "An act for the ascertainment of the amount due the Choctaw Nation" (21 Stat. 504 [1881]) as an early example of such "special jurisdictional acts" that allowed tribes to file in the Court of Claims. Rosenthal (1990, p. x) stated that Congress "brought forth 200 such acts by 1946." 
to hear each case through the passing of a special jurisdictional act. ${ }^{9}$ Cowen, Nichols, and Bennett (1978, p. 99) reported "only 142 claims under such statutes were adjudicated by the court prior to 1946, although many were large and important." ${ }^{10}$ Wilkinson (1966) in particular illuminated these procedural problems by describing the sixty-year journey through the courts by the Turtle Mountain Band of Chippewa.

The obstacles were many, however, and constant interactions between the tribes and Congress - frequently after an unsuccessful excursion through the courts - caused even more problems and delays. Yet in victory, the awards were regularly reduced through the application of a government setoff against the initial sum, even under findings of unconscionable consideration. ${ }^{11}$ Wilkinson (1966) offered two 1935 cases (Blackfeet Nations or Tribes of Indians v. United States and Shoshone Tribe of Indians of Wind River Reservation v. United States) to demonstrate this effect. The recoverable amounts of these two multi-million dollar awards to the tribes in these proceedings yielded only $10 \%$ and $32 \%$, respectively, after the setoff. These inequities were attenuated by further legislation that defined more clearly the acceptable applications of setoffs (see Section 2 on p. 596 in An act making appropriations to supply deficiencies, 1935). ${ }^{12}$

The special jurisdictional act impediment was removed in 1946 (An act to create an Indian Claims Commission) with the establishment of the Indian Claims Commission (ICC). ${ }^{13}$ The administrative decisions of the ICC were reviewed by the Court of Claims, with an opportunity of appeal to the United States Supreme Court. The Court was careful to avoid some of the previous, hampering problems. The classes of claims constructed for the ICC, described in Section 2 of the 1946 act, were examined closely; in particular, the

\footnotetext{
${ }^{10}$ Strickland (1982, p. 563) states, as well, that "[b]etween 1836 and 1946 Congress enacted 142 such acts."
}

${ }^{11}$ Ross (1973, p. v) supplied a definition for unconscionable consideration: "A determination of unconscionable consideration is a finding that the compensation originally paid by the Government for the Indian lands ceded by treaty or agreement was so low when compared to the market value at the time as to shock the conscience and entitle the tribe to recover, subject to gratuitous offsets, if any." Laurie (1978, p. 103) concluded that: "The major justification for offsets is that if Indians had received proper compensation for their lands initially they would not have needed subsequent gratuities."

12 Similarly, there were Senate adjustments (Compensating the Indians of California for the Value of Land Erroneously Used as an Offset in a Judgment Against the United States Obtained by Said Nations, 1969) to a Court of Claims judgment for an Indians of California suit (The Indians of California, 1944) that, due to offsets, had been reduced by $71 \%$. The original suit, brought by 23,571 census enrollees (The Indians of California v. the United States, 1942, p. 586), had been filed in part "to determine, adjudicate and render final decree in the matter of all equitable claims relating to the loss sustained by these Indians on account of their failure to secure and receive the lands, personal property, services, facilities, aids, improvements, and compensation provided for or proposed in those eighteen unratified treaties executed by certain chiefs and headmen of the several tribes and bands of Indians of California and commissioners representing the United States, between March 19, 1851 and January 7, 1852" (p. 585). A joint Congressional effort ([Defining "Gratuities"-Five Civilized Tribes, 1939] and [Defining "Gratuities"-Five Civilized Tribes, 1940]) struggled with offset issues affecting the Five Civilized Tribes suits (e.g., Seminole Nation v. United States (1935)) that cited ratified treaty number 303 and 352) before the Court. Previous legislation had empowered the tribes to approach the Court of Claims (Joint Resolution Authorizing the Cherokee Indians, 1926).

${ }^{13}$ See Pierce (1977) for a brief history. 
thresholds for claimant inclusion and the determination of "fair and honorable dealings" and "unconscionable consideration" within treaty or agreement contexts were carefully considered. The latter factor - unconscionable consideration — was the basis for most ICC claims (Ross, 1973).

Initially, the broad language of the "fair and honorable dealings" clause appeared to provide the impetus to expand the scope of claims beyond the confines established by treaties and other agreements (Newton, 1992). Indeed, Newton pointed to a Congressional committee report (Creating an Indian Claims Commission, 1945) to document the legislative intent behind this broad language. ${ }^{14}$ However, case results have seen mostly restricted interpretations, including Fort Sill Apache Tribe v. United States (1973), holding that the clause "is limited to somewhat fewer situations than a literal reading would imply” (p. 640).

Case decisions, including the Fort Sill Apache Tribe case, have shown "that recovery under [the clause] ... required the existence of a special undertaking by the government or a special relationship between the government and the [tribe]" (McDaniel, 1979, p. 692). The treaties were often the only tangible instruments by which to demonstrate a "special undertaking" or "special relationship." Ultimately, Newton (1992) concluded that the clause was "reduced ... to nothing more than a statutory or treaty claim, duplicating claims adjudicated under other provisions of the ... Act" (p. 783).

While the Act presented a moral façade with "fair and honorable dealings" and "unconscionable consideration," the continued use of offsets, and in fact, the inclusion of "gratuitous" offset provisions, generally succeeded in mitigating any intended obligation. Price (1973, p. 493), Newton (1992), and others ${ }^{15}$ provide numerous depictions of the continued effects of offsets on claims reparations since 1946. Newton (p. 819) characterized the rationales for permitting offsets as "rather dubious," and in some cases, as "laughable."

Rosenthal (1990) provided a complete history of the ICC as well as of the decades preceding this Court. He referred, in the section on the early history of claims administration, to attempts in the 1850 s by the federal government to include within treaty negotiations articles that waived all claims based on previous treaties. For example, the Omaha "relinquish[ed] to the United States all claims, for money or other thing, under former treaties, and likewise all claim which they may have heretofore, at any time, set up, to any land, on the east side of the Missouri River" (Treaty with the Omaha, 1854; Kappler, 1904, pp. 611-612). This orientation persevered well into the 20th century with the special jurisdictional act requirement to access the Court and the non-citizenship status of Indians until 1924. Rosenthal noted that "[f]rom 1881 to 1946, 219 claims were filed with the Court of Claims. Of these cases only thirty-five won awards" (p. 24). In comparison, the Court of Claims addressed 10,841 depredation claims between 1891 and 1920 (Sko-

${ }^{14}$ The purpose of the Indian Claims Commission was made quite clear in this Report: "The bill in its present form is primarily designed to right a continuing wrong to our Indian citizens for which no possible justification can be asserted" (p. 1), and "In order that the decisions reached under the proposed legislation shall have finality it is essential that the jurisdiction to hear claims which is vested in the Commission be broad enough to include all possible claims. If any class of claims is omitted, we may be sure that sooner or later that omission will lead to appeals for new special jurisdictional acts" (p. 10).

${ }^{15}$ See, for example, White (1978). 
gen, 1996). With the establishment of the ICC, Ross (1973) reported that the number of initial tribal petitions grew to 370 , and that these petitions were separated into 611 claims, each with unique ICC docket numbers. ${ }^{16}$ The initial legislation in 1946 provided for a 10year judicial period, but the Commission's tenure was extended until 30 September 1978, at which time all remaining cases were transferred to the Court of Claims.

The Court of Claims continued until 1982 at which time the Court's name was adjusted to the United States Claims Court (An act to establish a United States Court of Appeals for the Federal Circuit, 1982). The new Court retained the original jurisdiction of the Court of Claims. Table 1 contains 63 citations from 21 cases before this specific Court. ${ }^{17}$

Ten years later, through the Federal Court Administration Act of 1992 (An act to implement the recommendations of the Federal Courts Study Committee), the Court's name was changed to the United States Court of Federal Claims, and the eight cases between 1993 and 2004 are referenced in Table 1 by 20 citations.

In total, for the years following the creation of the ICC $^{18}$ - i.e., specifically for the interval 1950 through 2004-Table 1 contains 574 citations to 187 cases brought either initially to the Court or to it on appeal from the ICC. This is $58 \%$ of all citations and $55 \%$ of all cases before all three Courts of Claims.

\section{Table 1 and case selection}

In this study, there were two possible sources for relevant cases. First, the Checklist of United States Public Documents, $1789-1909$ (1911, pp. 604-605) identifies those United States Congressional Serial Set volumes that contain the first 295 Court of Claims decisions. ${ }^{19}$ Second, the Checklist also reveals that the Court of Claims Reports reporter commenced in 1867 , identifying Court of Claims opinions beginning in $1863 .{ }^{20}$ This latter resource contin-

${ }^{16}$ Docket number 1 pertained to the case of the Loyal Creek Band or Group and Claimant's Committee (Ross, 1973, p. 1), while docket number 370 was submitted by the Natives of Palmer, Alaska (p. 15). Barney (1955) noted that the Loyal Creek were an early example of a tribal "identifiable group" that could file suit as a separate claimant. The United States Indian Claims Commission Final Report (1979, p. iii) reports 617 dockets.

${ }^{17}$ There are 50 citations in Table 1, involving 19 unique cases between the years 1978 to 1981, that are identified with the LexisNexis electronic file designator. For example, the 1978 case Navajo Tribe of Indians v. United States cited ratified treaty number 86; this case is referenced as "1978 U.S. Ct. Cl. Lexis 644."

${ }^{18}$ Western (Old Settler) Cherokee Indians and Eastern (Emigrant) Cherokee Indians v. United States (1948) was the first case decided by the ICC.

${ }^{19}$ The Checklist notes that the case reports are numbered 1 through 296, but that the House of Representatives never received Report number 42. See Bernholz and Ellis (2006) for an investigation into Court of Claims Report 42.

${ }^{20} \mathrm{An}$ act in relation to the Court of Claims (1866) mandated this formal printing requirement. Section 3 specifies that "a copy of the decisions" was to be sent to various officials at the end of each term of the Court of Claims. Richardson $(1885$, p. 16) states that "Judge [Charles C.] Nott, in connection with the clerk, commenced in the year 1867 the regular publication of reports, under the title of 'Court of Claims Reports." 
ued as the main legal reporter of subsequent final decisions of the Court of Claims.

- Early cases (1855-1862)

The Readex United States Congressional Serial Set ${ }^{21}$ database was used to search for appropriate cases in the following manner. First, all 295 Court of Claims reports were retrieved with the "Publication Search" option; the final case in this series, William G. Brown was dated 23 December 1862. This subset was then re-examined for the incidence of the term "treaty OR treaties" and of the term "Indian OR Indians OR tribe" in the text of the report. Twenty-six possible cases were acquired in this manner and of these, 12 cases made 44 citations to a recognized Indian treaty ${ }^{22}$ or treaty supplement. ${ }^{23}$ Each of these final cases has been placed in Table 1 in the case title and in the citation columns as, for example, "John C. Hale (1856)" and "C.C.Rpt. 19." The Serial Set citation for each such case is listed in this footnote in Court of Claims Report number order. ${ }^{24}$

- Later cases (1863-present)

Those cases after 1862 from the various Courts of Claims were selected by using each

${ }^{21}$ See the product description at http://www.newsbankonline.com/readex/.

${ }^{22}$ The Department of State ratified treaty numbering system identifies those treaties that have been recognized by the federal government. All the 374 ratified treaties in that formal numbering systemplus the never formally promulgated Treaty of Fort Laramie with Sioux, etc., 1851 (Kappler, 1904, pp. 594-596) that has been assigned the fictitious ratified treaty number 999-were examined here. The United States Court of Claims itself ruled that, although never formally proclaimed or given a ratified treaty number by the Department of State, the Treaty of Fort Laramie with Sioux, etc., 1851 "is binding upon the parties" (Royv. United States, 1910). The texts and images of the original treaties may be examined in the microfilm collection Ratified Indian Treaties, 1722-1869 (1966). Legislation in 1871 ended treaty making: "Provided, further, that nothing herein contained shall be construed to invalidate or impair the obligation of any treaty heretofore lawfully made and ratified with any such Indian nation or tribe" (16 Stat. 544, 566).

${ }^{23}$ Treaty supplements affected parameters of previously negotiated instruments, and occurred in two general forms: supplemental articles and supplementary treaties (Bernholz, 2006). These are entered in Table 1 as decimal additions to the ratified treaty number of the affected document. For example, the first occurrence is under ratified treaty number 103.1, the Treaty with the Delawares, 1829 (Kappler, 1904, pp. 304-305), a supplementary treaty that modified aspects of ratified treaty number 103, the Treaty with the Delawares, 1818 (pp. 170-171). In Table 1, there are 16 individual supplementals: six supplemental articles (ratified treaty number 161.1, 173.1, 189.1, 191.1, 199.2, 308.1, and 309.1) and nine supplementary treaties (ratified treaty number 103.1, 123.1, 152.1, 253.1, 265.1, 291.1, 293.1, 306.1, and 327.1). Supplemental articles number 308.1 and 309.1 are the same 1860 document (Right and title of certain bands of Sioux Indians, to lands embraced in reservation on the Minnesota River; Kappler, 1904, p. 789) that changed the 1858 treaties of the Mdewakanton and Wahpekute (pp. 781-785), and the Sisseton and Wahpeton (pp. 785-789) bands of Sioux, respectively.

${ }^{24}$ The twelve cases are as follows: James M. Lindsay (1856); John C. Hale (1856); J. K. Rogers (1857); Robert Harrison (1857); Neal Smith, administrator of William Turvin (1857); Joshua J. Guppey, county judge of Columbia County, Wisconsin, as trustee for the settlers and occupants of "Portage City" (1858); State of Alabama (1858); Doctor James Thacher - Heirs of (1859); Charles V. Stuart (1859); James Preston Beck, administrator of Preston Beck, Jr. (1861); Stephen Johnston and others, heirs-atlaw of Stephen Johnston (1861); and James L. Johnson, surviving partner of the firm of Beck \& Johnson (1862).

${ }^{25}$ Volumes of Statutes at Large are now available on the Library of Congress's Century of Lawmaking for a New Nation page at http://memory.loc.gov/ammem/amlaw/lwsl.html. The texts of all treaties in Table 1 are available at this site. 
treaty's Statutes at Large reference ${ }^{25}$ to identify case entries in the volumes of Shepard's Federal Statute Citations. ${ }^{26}$ In addition, each treaty's Statutes at Large notation was re-examined with the full LexisNexis online database to identify any case not reported in Shepard's Federal Statute Citations. The same suite of Statutes at Large references was submitted to the Web-based Westlaw Campus system as well.

By combining these early and late cases, Table 1 was constructed to identify the 992 citations to 240 of 375 recognized Indian treaties or to 16 supplements found in 342 Court opinions between the years 1884 (Chickasaw Nation v. United States and Connor v. United States) and 2004 (Wolfchild v. United States).

Table 1 is an aggregate of the following data:

- The ratified treaty number, assigned by the Department of State, ${ }^{27}$ of each of the relevant treaties or supplements that has been cited in the opinion of any Claims court;

- The name(s) of the participating tribe(s), with an expansion of the "etc." found in the titles of many treaties in Kappler's work into a complete list of parties. For example, ratified treaty number 9 is the Treaty with the Six Nations, 1784 (Kappler, 1904, pp. 5-6) and the entry for this document in Table 1 identifies as signatories the Cayuga, Mohawk, Oneida, Onondaga, Seneca, and Tuscarora;

- The signing date of the treaty, taken from each treaty's entry in volume 2 of Kappler's Indian Affairs: Laws and Treaties (1904), or in the case of the sole pre-Revolutionary War document, the date in an alternate source; ${ }^{28}$

- The treaty page number in Indian Affairs: Laws and Treaties (1904);

- The Statutes at Large citation for the treaty; ${ }^{29}$

- The case title and year of the citing case; and

- The reporter citation for this case.

One final note is required. (Bernholz, 2001) and (Bernholz, 2002) identified those treaties that had never appeared in the opinion of any federal court. Ratified treaty number 141 - the Treaty with the Pawnee Tribe, 1825 (Kappler, 1904, pp. 258-260)—was among those documents. As part of the Westlaw Campus analysis of Statutes at Large citations for this study, Pawnee Indian Tribe of Oklahoma v. United States (1953) was retrieved. The use of this treaty in that Claims case thereby reduces to 80 the total number of recognized American Indian treaties that have never been cited in federal jurisdictions.

${ }^{26}$ Shepard's Federal Statute Citations (1996), Shepard's Federal Statute Citations: Statute Edition Supplement, 1996-2001 (2001), and Shepard's Federal Statute Citations: Statute Edition Supplement, 2001-2003 (2003) were used in this study. Cumulative soft-covered issues update these bound permanent volumes.

${ }^{27}$ See Ratified Indian Treaties, $1722-1869$ (1966). There is also a list of these assigned numbers in Appendix B of Francis Paul Prucha's American Indian Treaties: The History of a Political Anomaly (1994). The latter list does not include the first seven recognized treaties that were created by the British before the Revolutionary War.

${ }^{28}$ Ratified treaty number 7, the Treaty of Fort Stanwix, or The Grant from the Six Nations to the King and Agreement of Boundary Line-Six Nations, Shawnee, Delaware, Mingoes of Ohio, 1768, does not appear in the Statutes at Large. It is entered in the "Kappler Page Number" column of Table 1 as "EAID 10, 541" to denote page 541 in Vaughan and Graymont (2001).

${ }^{29}$ Ratified treaty number 28 appears only on page 641 of the first volume of the American State Papers: Indian Affairs (1832). This document is identified in the "Statutes at Large" column as "ASP:IA 1, 641." 


\section{Conclusions}

In the first digest of the cases before the Court (Devereux, 1856, p. 12), the Presiding Judge — John James Gilchrist ${ }^{30}$ — noted in a letter dated 23 June 1856 to the Senate and the House of Representatives that "[u]ntil the institution of this court, there had never been anything like a systematic inquiry into the modes of action by the government through the executive departments, or the relation in regard to contracts and the liabilities arising therefrom which the government bore to the citizens." The James M. Lindsay (1856) case in Table 1 was one of the "[c]ases involving the proper construction of treaties" (p. 13) that came before the Court, and digest items 349 through 353, under the subject heading of "Indians" (pp. 92-93) resulted from the Lindsay case.

In her final sentence describing government negotiations with their respective tribes during the late 1860s in both the United States and in Canada, St. Germain (2001) concluded that: "the means that they chose - treaties - in both cases ensured a rebirth for the very peoples they had sought to absorb, this time around in courts of law and firmly based on the legal instruments nineteenth-century governments had sought to employ to their own advantage" (p. 165). The 342 Court of Claims opinions noted in this article-in concert with the more than 600 dockets from the Indian Claims Commission era-firmly substantiate her claim of such a "rebirth," but these claims proceedings also include the use by non-tribal members of these documents. In the early digest of Court of Claims cases, Judge Gilchrist stated that the Court "decided that in order to justify a decision in favor of a claimant, his claim must in all cases be founded on some legal right" (p. 12). He acknowledged the Lindsay proceedings as one such exemplar.

The Lindsay case has added significance. In terms of the cases presented here, it was one of the two earliest ${ }^{31}$ Court of Claims proceedings to cite an Indian treaty. Lindsay had purchased property that had been part of reserved Creek lands. The Treaty with the Creeks, 1814 (Kappler, 1904, pp. 107-110) stipulated that any reserved lands that were subsequently left unoccupied "shall devolve to the United States" (p. 108). With the operational status of the court in 1856 centered more upon an advisory instead of upon a judicial process, court opinions were delivered to Congress more as proposals for consideration than as legal decisions. As a result of this orientation, the court reported to the House Committee their findings that-based on the parameters of the Creek treatyLindsay had "no legal cause of action against the United States" (James M. Lindsay, 1856 , p. 16) and so the government was not required to convey the land to him, even if he and his predecessors had purchased it in good faith from tribal members. However, the court noted as well that "[i]t can make no difference to the United States whether the fee is in the heirs of the reservees or in the petitioner; and there would seem to be no necessity that, in a matter so important to the petitioner, and so unimportant to the United States, they should avail themselves of what is a strict legal right" (p. 17). Similar, successful private land claims, that had involved previously the same treaty, were enumerated by the court and, with these court suggestions in hand, Congress - in a joint res-

${ }^{30}$ See a brief biography of Gilchrist in Bennett (1976, pp. 1-3).

${ }^{31}$ The John C. Hale (1856) case, Court of Claims Report 19, was dated 16 May 1856, just as the Lindsay one. Lindsay is Court of Claims Report 10. 
olution 3 months later-confirmed Lindsay's claim (An act for the relief of James M. Lindsay, 1856).

The quest for Judge Gilchrist's true "systematic inquiry" within the Court of Claims could only occur, however, if the court could make decisions that were not overturned or diluted in some manner by a Congressional committee. The most recent case in Table 1 in this article-Wolfchild v. United States (2004) before the Federal Claims Court-shows the growth of empowerment that resulted from later legislative adjustments to the Claims Court. This action cited three annuity-granting treaties: the Treaty with the Sioux, 1837, the Treaty with the Sioux - Sisseton and Wahpeton Bands, 1851, and the Treaty with the Sioux-Mdewakanton and Wahpakoota Bands, 1851 (Kappler, 1904, pp. 493-494, 588590, and 591-593). The government, as partial punishment for the 1862 Minnesota Sioux Outbreak, withdrew the annuities from the perpetrators. ${ }^{32}$ Those band members whom had remained loyal to the United States were permitted to stay on the land defined within the treaties. Later legislation in 1888, 1889, and 1890 created a program for allotment of up to 80 acres per loyalist, and for financial considerations. The Department of the Interior, however, kept under trust the title to the land and the government managed these lands until, in 1980, they were disbursed to three Indian groups formed through the Indian Reorganization Act of 1934: the Lower Sioux Indian Community in Minnesota, the Shakopee Mdewakanton Sioux (Dakota) Community, and the Prairie Island Indian Community in Minnesota. These three communities were mostly non-descendants of the loyalists. In Wolfchild, more than 250 lineal members of the original loyalists filed for breach of fiduciary duty and contract by the United States, caused, in part, by the "extraordinarily poor drafting reflected in the 1980 Act" (Wolfchild v. United States, 2004, p. 532). However, the judicial process in this case was very different from that seen in Lindsay. The inability, between 1863 and the onset of the Indian Claims Commission in 1946, to raise treaty-based claims meant that few tribal claims questions could be answered, even if the changes in 1863 made the court a more judicial than an advisory one. As noted, special jurisdictional acts were required during this period, as they were for the Sisseton and Wahpeton Bands of Indians and the Medawakanton and Wahpakoota Bands of Sioux Indians cases.

In Wolfchild, the same fundamental type of treaty-specific questions prevailed, and the court granted, in part, that "(1) a trust was created in connection with and as a consequence of the 1888, 1889, and 1890 Appropriation Acts for the benefit of the loyal Mdewakanton and their lineal descendants, which trust included land, improvements to land, and monies as the corpus, (2) such trust was neither extinguished nor terminated by the 1980 Act, and (3) such trust was breached by the United States through actions taken in December 1980 and thereafter" (Wolfchild v. United States, 2004, p. 555).

\footnotetext{
${ }^{32}$ Two later Court of Claims cases were authorized to address this annuity loss. The Sisseton and Wahpeton Bands received \$788,971.53 (Sisseton \& Wahpeton Bands of Indians v. United States, 1907), while the Mdewakanton and Wahpakoota Bands recovered \$386,597.89 (Medawakanton \& Wahpakoota Bands of Sioux Indians v. United States, 1922). The two cases are listed as well in Table 1 under the three ratified treaty numbers - 224, 258, and 259 — cited in Wolfchild. The bands cited additional treaties to substantiate their claims: ratified treaty number 360 by the Sisseton and Wahpeton Bands, and ratified treaty number 308, 309, 360, and 369 by the Mdewakanton and Wahpakoota.
} 
In this later decision, the court reached beyond the uneven early days of the Court of Claims and demonstrated the continuing relevance and usefulness of the treaties created between the Indian Nations and the federal government. The proposals found in the Lindsay opinion rested more upon the private acts, grounded in the same claims-treaty conditions as Lindsay, that Congress had enacted previously, while Wolfchild exposed a trust responsibility that developed from federal legislative acts constructed after the cited treaties had been consummated. These two opinions, pronounced a century and a half apart, were one of the earliest, and then one of the most recent, positive demonstrations of the court's mandate. In the years between these two cases, the Indian Claims Commission attempted to address hundreds of cases of unconscionable considerations that adhered to the Indian land cessions conveyed by treaty.

Many of the other cases in Table 1-some impeded by, and some freed from, the constraint of acquiring a special jurisdictional act to proceed - might never have been heard, had it not been for this forum. In addition, the ability to appeal Court of Claims decisions to the United States Supreme Court meant that there was another opportunity for consideration. Many important Court of Claims cases involving Indian treaties later came before the Supreme Court. ${ }^{33}$

In the case of proceedings delayed by the need to acquire special jurisdictional acts, Congress took almost 20 years to create the Indian Claims Commission, even after the admonition raised about this organizational hindrance in the 1928 Institute of Government Research survey report for the Department of Interior entitled The Problem of Indian Administration. ${ }^{34}$ In Chapter 13, on the topic of "Legal Aspects of the Indian Problem," the survey was concerned that " $\mathrm{t}]$ he necessity for such congressional action introduces political considerations into what should be solely a judicial question" (The Problem of Indian Administration, 1928, p. 805). It was declared also that "[m]any tribal claims are in process of adjudication, but some have not yet reached the preliminary stage of being approved by Congress for presentation to the Court of Claims. It is extremely important that all claims be settled at the earliest possible date. It is therefore recommended that a special commission be appointed to study the remaining claims and to submit recommendations to the Secretary of the Interior regarding their merits, so that those which are meritorious may be submitted to Congress with a draft of a suitable bill authorizing their settlement before the Court of Claims" (p. 748, emphasis added).

Congress, however, did feel the need to address past transgressions, as well as to acknowledge the contributions of tribal members for their service in the two world wars. ${ }^{35}$ In 1924, national citizenship was conferred by Congress on "all non-citizen Indians born within the territorial limits of the United States" (An act to authorize the Secretary of the Interior to issue certificates of citizenship to Indians, 1924). Moreover, while offset pro-

\footnotetext{
${ }^{33}$ See Strickland's (1982, pp. 562-574) discussion of tribal claims and examples of actions that appeared before both courts.

34 This publication is known also as the Meriam Report, named after the Technical Director of the study's Survey Staff, Lewis Meriam.

${ }^{35}$ See specifically pp. 1-2 of Creating an Indian Claims Commission (1945) for a "History of the Legislation."
} 
visions and narrow interpretations of "fair and honorable dealings" and "unconscionable consideration" often significantly impaired reparations, the creation of the Indian Claims Commission can be seen as another effort by 20 th century government to make amends.

There were subsequent questions before the court, after the termination of the Indian Claims Commission, that dealt specifically with treaty parameters and other episodes of unconscionable consideration for ceded land, or with tribal fund management shortcomings, or with legislation issues like those in Wolfchild, that were released from such procedural burdens. Pawlitz (2001, p. 1361), in his article on the issue of the indispensability of the federal government in Indian land claims proceedings, pointed out that even today, government control "when combined with Indians' unique position within the federal system, closely links the protection of Indian rights to the United States' willingness to allow or become a party to litigation on the Indians' behalf." He concluded that careful consideration of this indispensability matter will "ensure that the courts are not responsible for yet another injustice to be borne by American Indians" (p. 1388).

By creating the Court of Claims and its successors, the federal government did allow itself to "become a party to litigation on the Indians' behalf." In the cases before this jurisdiction that distinctively pertained to Indian treaty issues, the courts endeavored to invoke the kernel of responsibility that President Abraham Lincoln had remarked upon in his first annual message in 1861: "It is as much the duty of government to render prompt justice against itself, in favor of citizens, as it is to administer the same between private individuals" (Message of the President, 1862).

\section{Acknowledgment}

We thank Francis Paul Prucha, S. J., for his constructive comments regarding this article.

Supplementary Data — Table 1 appears here on pages 328-394.

\section{References}

Abuses in the prosecution of claims. (1852). The Congressional Globe, 32d Congress, 1st session, $6 \mathrm{Au}-$ gust 1852, 2100-2101.

American State Papers: Indian Affairs: Vol. 1. (1832). Washington, DC: Gales and Seaton.

An act for the relief of James M. Lindsay. (1856). 11 Stat. 483.

An act in relation to the Court of Claims. (1866). 14 Stat. 9.

An act making appropriations to supply deficiencies in certain appropriations for the fiscal year ending June 30, 1935, and for prior fiscal years, to provide supplemental appropriations for the fiscal years ending June 30, 1935, and June 30, 1936, and for other purposes. (1935). 49 Stat. 571.

An act to amend "An act to establish a court for the investigation of claims against the United States," approved February twenty-fourth, eighteen hundred and fifty-five. (1863). 12 Stat. 765.

An act to authorize the Secretary of the Interior to issue certificates of citizenship to An act to authorize the Secretary of the Interior to issue certificates of citizenship to Indians. (1924). 43 Stat. 253.

An act to create an Indian Claims Commission, to provide for the powers, duties, and functions thereof, and for other purposes. (1946). 60 Stat. 1049.

An act to establish a court for the investigation of claims against the United States. (1855). 10 Stat. 612.

An act to establish a United States Court of Appeals for the Federal Circuit, to establish a United States 
Claims Court, and for other purposes. (1982). 96 Stat. 25.

An act to implement the recommendations of the Federal Courts Study Committee, and for other purposes. (1992). 106 Stat. 4506.

An act to provide for the adjudication and payment of claims arising from Indian depredations. (1891). 26 Stat. 851.

An act to provide for the bringing of suits against the government of the United States. (1887). 24 Stat. 505.

Barney, R. A., Legal problems peculiar to Indian claims litigation, Ethnohistory 2 (1955), pp. 315-325.

Bennett, M. T. (1976). The United States Court of Claims: A History, Part I: The Judges: 1855-1976. Washington, DC: Committee on the Bicentennial of Independence and the Constitution of the Judicial Conference of the United States.

Bernholz, C. D. The absent American Indian treaties: A guide to treaties never referenced at the federal court level, Journal of Government Information 28 (2001), pp. 171-178.

Bernholz, C. D., The absent American Indian treaties: An update, Journal of Government Information 29 (2002), pp. 39-41.

Bernholz, C. D. (2006). Adjusting American Indian treaties: A guide to supplemental article and supplementary treaty citations from opinions of the Federal, State, and Territorial Court Systems. Submitted to Government Information Quarterly.

Bernholz, C. D., and W.R. Ellis, The missing Court of Claims Report: Is Letitia Humphreys Court of Claims Report 42?, Government Information Quarterly 23 (2006), pp. 309-324.

Blackfeet Nations or Tribes of Indians v. United States, 81 Ct. Cl. 101 (1935).

Board of Claims. (1838). House of Representatives. 25th Congress, 2d session. House of Representatives Report No. 730, Serial Set 335. Washington, DC: Thomas Allen.

Bradford, W., "With a very great blame on our hearts:" Reparations, reconciliation, and an American Indian plea for peace with justice, American Indian Law Review 27 (2002), pp. 1-90.

Charles v. Stuart. (1859). 35th Congress, 2nd Session. Court of Claims Report 190, Serial Set 1021. Washington, DC: James B. Steedman.

Checklist of United States Public Documents, 1789-1909. (1911). Washington, DC: Government Printing Office.

Chickasaw Nation v. United States, 19 Ct. Cl. 133 (1884).

Claims Against the United States. (1848). House of Representatives. 30th Congress, 1st session. House of Representatives Report No. 498, Serial Set 526. Washington, DC: Wendell and Van Benthuysen.

Compensating the Indians of California for the Value of Land Erroneously Used as an Offset in a Judgment Against the United States Obtained by Said Nations. (1969). Senate. 91st Congress, 1st session. Senate Report No. 91-381, Serial Set 12834-3. Washington, DC: Government Printing Office.

Connor v. United States, 19 Ct. Cl. 675 (1884).

Cowen, W., Nichols, P., \& Bennett, M. T. (1978). The United States Court of Claims: A History, Part II: Origin-Development-Jurisdiction 1855-1978. Washington, DC: Committee on the Bicentennial of Independence and the Constitution of the Judicial Conference of the United States.

Creating an Indian Claims Commission. (1945). House of Representatives. 79th Congress, 1st session. House of Representatives Report No. 1466, Serial Set 10936. Washington, DC: Government Printing Office.

Defining "Gratuities"-Five Civilized Tribes. (1939). Senate. 76th Congress, 1st session. Senate Report No. 860, Serial Set 10295. Washington, DC: Government Printing Office.

Defining "Gratuities"-Five Civilized Tribes. (1940). House of Representatives. 76th Congress, 3d session. House of Representatives Report No. 1991, Serial Set 10441. Washington, DC: Government Printing Office.

Devereux, J. C., Court of Claims: Reports and Digest of Opinions Delivered Since the Organization of the Court, Banks, Gould, \& Co., New York (1856). 
Doctor James Thacher-Heirs of. (1859). 35th Congress, 2nd Session. Court of Claims Report 185, Serial Set 1021. Washington, DC: James B. Steedman.

Fort Sill Apache Tribe v. United States, 201 Ct. Cl. 630 (1973).

Gordon v. United States, 69 U.S. 561 (1864).

J. K. Rogers. (1857). 34th Congress, 3rd Session. Court of Claims Report 46, Serial Set 915. Washington, DC: Cornelius Wendell.

James L. Johnson, surviving partner of the firm of Beck \& Johnson. (1862). 37th Congress, 2nd Session. Court of Claims Report 290, Serial Set 1146. Washington, DC: Government Printing Office.

James M. Lindsay. (1856). 34th Congress, 1st Session. Court of Claims Report 10, Serial Set 871. Washington, DC: Cornelius Wendell.

James Preston Beck, administrator of Preston Beck, Jr. (1861). 37th Congress, 2nd Session. Court of Claims Report 282, Serial Set 1146. Washington, DC: Government Printing Office.

John C. Hale. (1856). 34th Congress, 1st Session. Court of Claims Report 19, Serial Set 871. Washington, DC: Cornelius Wendell.

Joint resolution authorizing the Cherokee Indians, the Seminole Indians, the Creek Indians, and the Choctaw and Chickasaw Indians to prosecute claims, jointly or severally, in one or more petitions, as each of said Indian nations or tribes may elect. (1926). 44 Stat. 568.

Joshua J. Guppey, county judge of Columbia County, Wisconsin, as trustee for the settlers and occupants of "Portage City." (1858). 35th Congress, 1st Session. Court of Claims Report 166, Serial Set 972. Washington, DC: James B. Steedman.

Kappler, C. J., Indian Affairs: Laws and treaties: Vol. 2. Treaties, Government Printing Office, Washington, DC (1904).

Laurie, N. O., The Indian Claims Commission, Annals of the American Academy of Political and Social Science 436 (1978), pp. 97-110.

McDaniel, B., Annotation: Application and effect of "fair and honorable dealings" clause of Indian Claims Commission Act (25 USCS § 70a (5)) to claims of Indians against United States, American Law Reports Annotated, Federal 45 (1979), pp. 680-714.

Medawakanton and Wahpakoota Bands of Sioux Indians v. United States, 57 Ct. Cl. 357 (1922).

Message of the President. (1862). Appendix to The Congressional Globe, 37th Congress, $2 \mathrm{~d}$ session, 3 December 1861.

Neal Smith, administrator of William Turvin. (1857). 35th Congress, 1st Session. Court of Claims Report 134, Serial Set 971. Washington, DC: James B. Steedman.

Newton, N. J., Indian claims in the courts of the conqueror, American University Law Review 41 (1992), pp. 753-854.

Pawlitz, A. L., The United States' indispensability in Indian land claims: The proper application of Provident Tradesmens, St. Louis University Law Journal 45 (2001), pp. 1349-1387.

Pawnee Indian Tribe of Oklahoma v. United States, 124 Ct. Cl. 324 (1953).

Peters, R., Editor, Private Statutes at Large of the United States of America, Little, Brown and Co., Boston, MA (1862).

Pierce, M. H., The work of the Indian Claims Commission, American Bar Association Journal 63 (1977), pp. 227-232.

Price, M. E., Law and the American Indian: Readings, notes and cases, Bobbs-Merrill, New York (1973).

Prucha, F. P., American Indian Treaties: The History of a Political Anomaly, University of California Press, Berkeley, CA (1994).

Ratified Indian Treaties, 1722-1869. (1966). Washington, DC: National Archives and Records Service.

Richardson, W. A., History, Jurisdiction, and Practice of the Court of Claims, Government Printing Office, Washington, DC (1885).

Robert Harrison. (1857). 35th Congress, 1st Session. Court of Claims Report 127, Serial Set 971. Washington, DC: James B. Steedman. 
Rosenthal, H. D., Their Day in Court: A History of the Indian Claims Commission, Garland Publishing, New York (1990).

Ross, N. A., Editor, Index to the Decisions of the Indian Claims Commission, Clearwater Publishing, New York (1973).

Roy v. United States, 45 Ct. Cl. 177 (1910).

St. Germain, J., Indian Treaty-making Policy in the United States and Canada, 1867-1877, University of Nebraska Press, Lincoln, NE (2001).

Seminole Nation v. United States, 82 Ct. Cl. 135 (1935).

Shepard's Federal Statute Citations: Vol. 6 (8th ed.). (1996). Colorado Springs, CO: Shepard's/McGrawHill Inc.

Shepard's Federal Statute Citations: Statute Edition Supplement, 1996-2001: Vol. 4. (2001). Colorado Springs, CO: Lexis Publishing.

Shepard's Federal Statute Citations: Statute Edition Supplement, 2001-2003: Vol. 2. (2003). Colorado Springs, CO: Lexis Publishing.

Shimomura, F. D., The history of claims against the United States: The evolution from a legislative toward a judicial model of payment, Louisiana Law Review 45 (1985), pp. 625-700.

Shoshone Tribe of Indians of Wind River Reservation v. United States, 82 Ct. Cl. 23 (1935).

Sisseton and Wahpeton Bands of Indians v. United States, 42 Ct. Cl. 416 (1907).

Skogen, L. C., Indian Depredation Claims: 1796-1920, University of Oklahoma Press, Norman, OK (1996).

State of Alabama. (1858). 35th Congress, 2nd Session. Court of Claims Report 181, Serial Set 1021. Washington, DC: James B. Steedman.

Stephen Johnston and others, heirs-at-law of Stephen Johnston. (1861). 37th Congress, 2nd Session. Court of Claims Report 286, Serial Set 1146. Washington, DC: Government Printing Office.

Strickland, R. (Ed.). (1982). Felix S. Cohen's Handbook of Federal Indian Law (1982 ed.). Charlottesville, VA: Michie.

The Indians of California, 102 Ct. Cl. 837 (1944).

The Indians of California v. United States, 98 Ct. Cl. 583 (1942).

The Problem of Indian Administration. (1928). Baltimore, MD: Johns Hopkins Press.

Toelle, J. H., The Court of Claims: Its jurisdiction and principal decisions bearing on international law, Michigan Law Review 24 (1926), pp. 675-697.

United States Indian Claims Commission Final Report. (1979). Washington, DC: Government Printing Office.

United States v. Klein, 80 U.S. 128 (1871).

United States v. Realty Co., 163 U.S. 427 (1896).

Vaughan, A. T., \& Graymont, B. (Eds.). (2001). Early American Indian Documents: Treaties and Laws, 1607-1789, vol. 10: New York and New Jersey Treaties, 1754-1775. Bethesda, MD: University Publications of America.

Western (Old Settler) Cherokee Indians and Eastern (Emigrant) Cherokee Indians v. United States, 1 Ind. Cl. Comm. 1 (1948).

White, J. R., Barmecide revisited: The gratuitous offset in Indian claims cases, Ethnohistory 25 (1978), pp. 179-192.

Wilkinson, G. A., Indian tribal claims before the Court of Claims, Georgetown Law Journal 55 (1966), pp. 511-528.

William G. Brown. (1862). 37th Congress, 3rd Session. Court of Claims Report 296, Serial Set 1173. Washington, DC: Government Printing Office.

Wolfchild v. United States, 62 Fed. Cl. 521 (2004). 


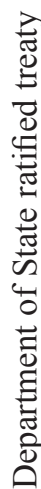
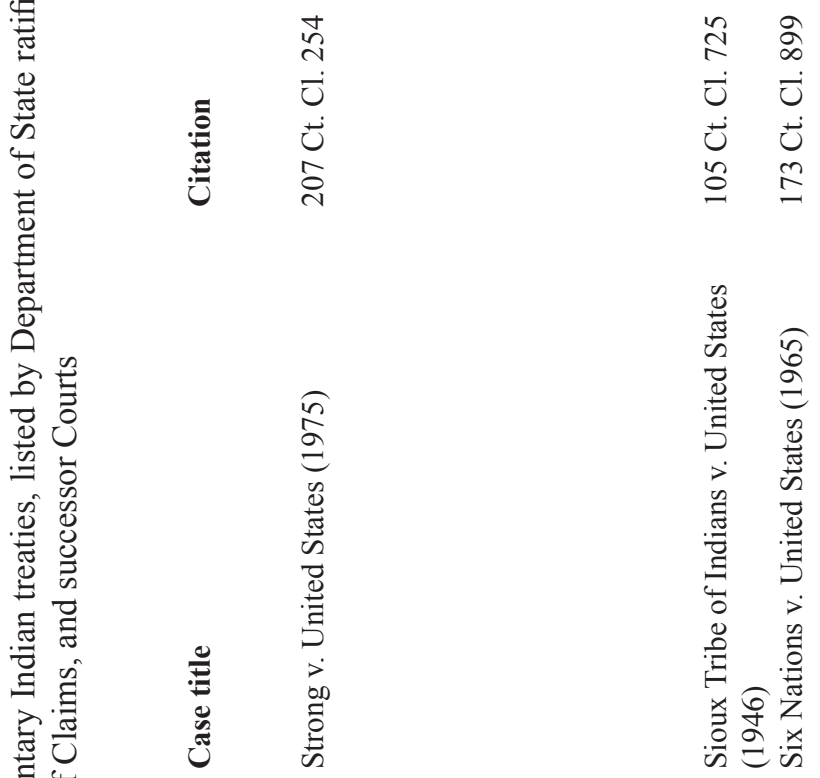

초ํㅇำ

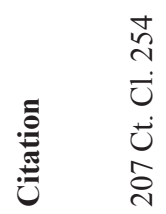

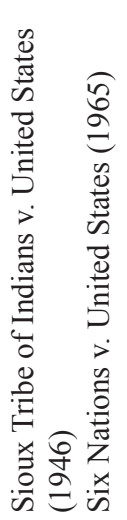

$\dot{U} \quad \dot{U} \dot{U} \dot{U}$

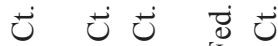

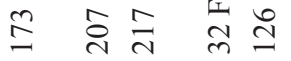

范

월

吾语

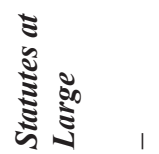

$\begin{array}{ll}n & n \\ \text { 焉 } & \text { 离 } \\ r & n\end{array}$

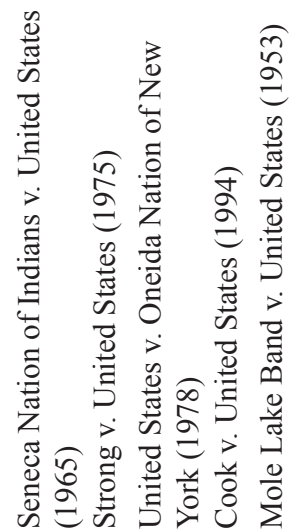

氖兽

胥急

오 음

$\frac{0}{0} \cdot \frac{0}{0}$

总 表

एँ

产音过

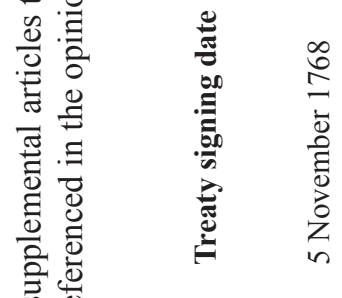

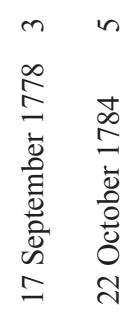

$\because 2 n$ 는

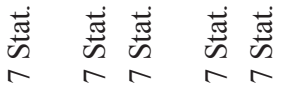

की

$\stackrel{0}{0}$

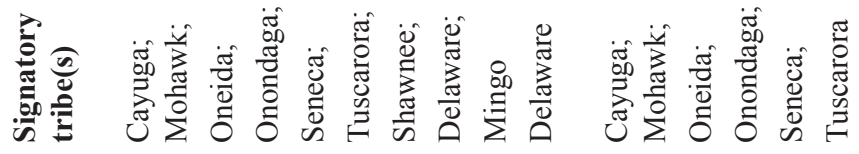

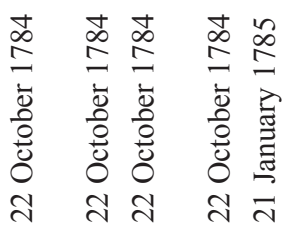

크

丞

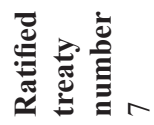

它

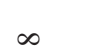



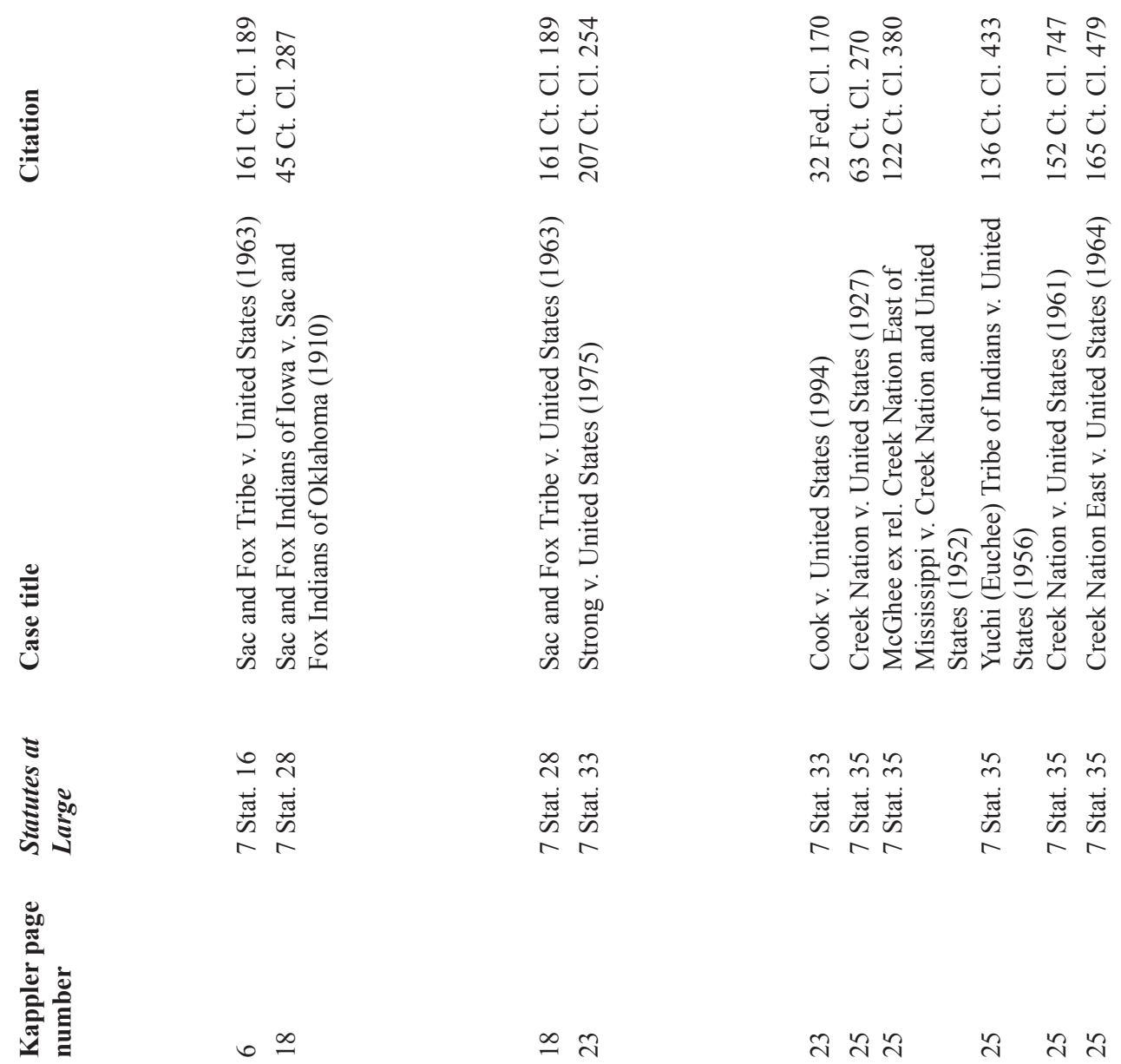

$0 \stackrel{\infty}{-}$

$\stackrel{2}{\sim}$

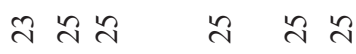

节

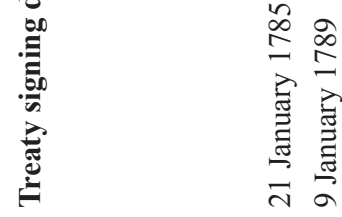

$\stackrel{\infty}{\infty} \stackrel{\infty}{=}$

ஓ̊ 욛

壳 志

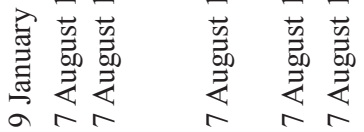

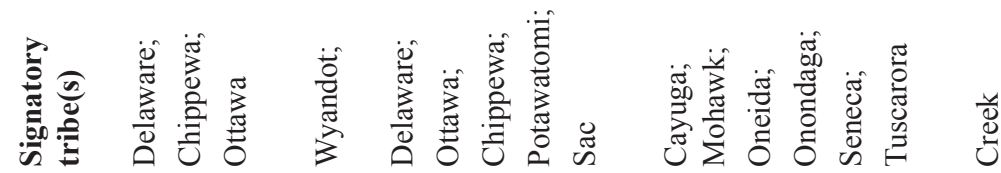
莺 莺

$ㅇ$

$\cong 0$

드 $こ I$ 


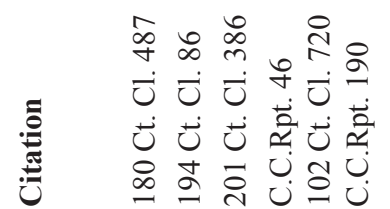

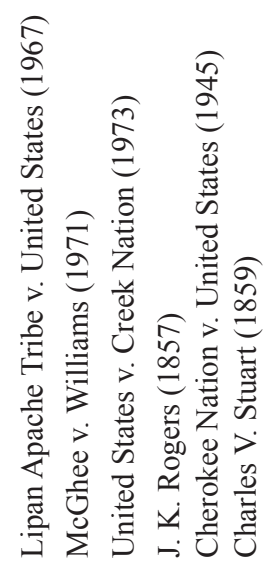

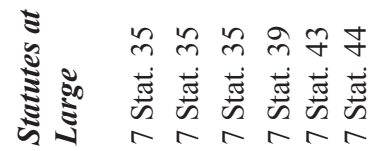

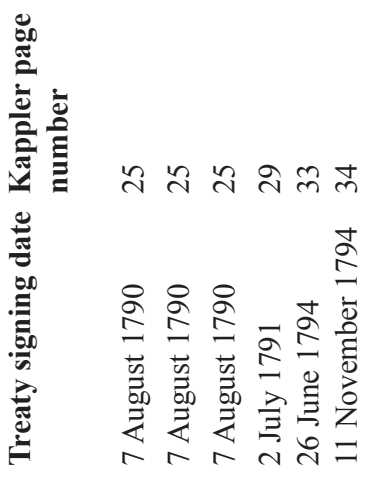

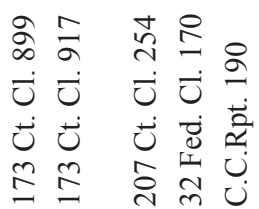

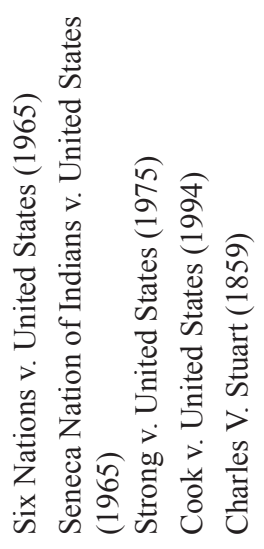

オす オす守

志恋志芯志

से फें ले

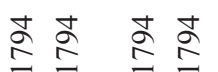

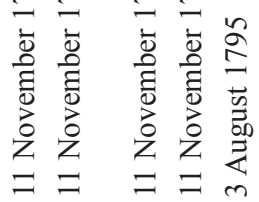
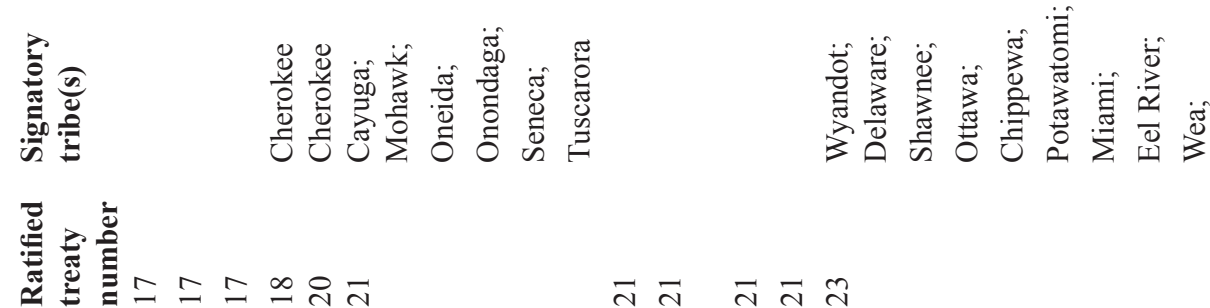

$\vec{\sim} \vec{\sim} \approx$ 


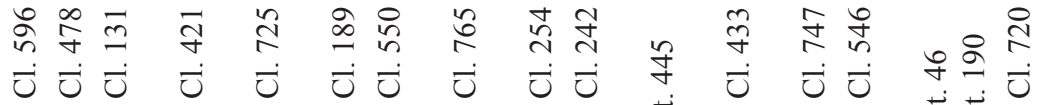

:

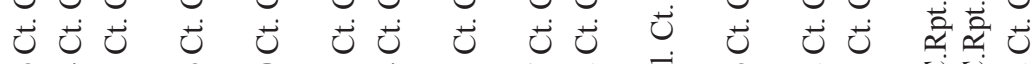

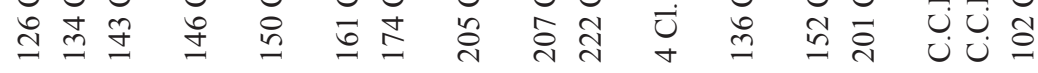

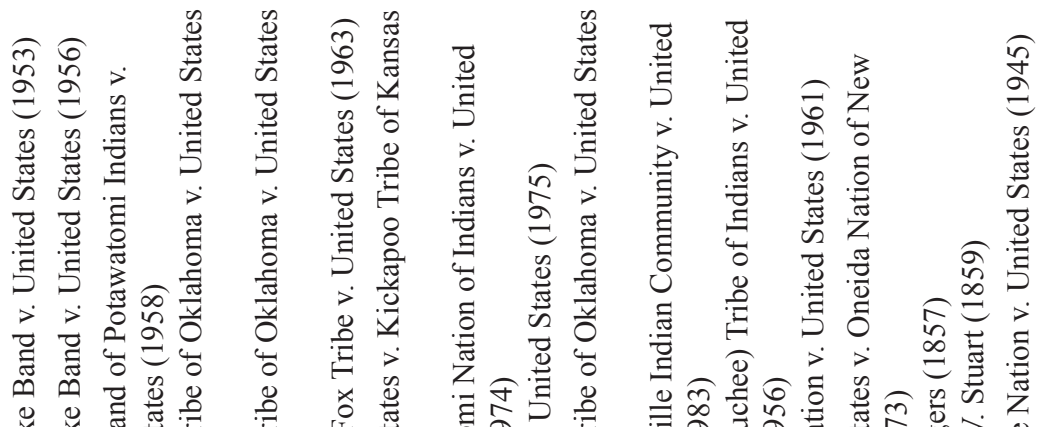

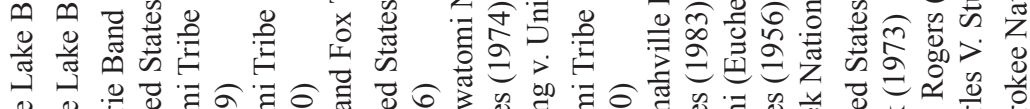

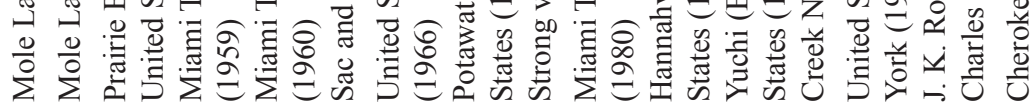

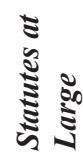

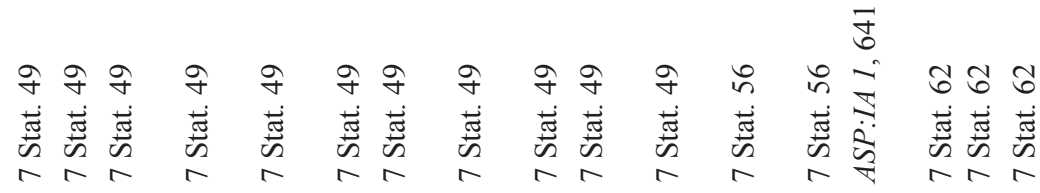

要

䒕

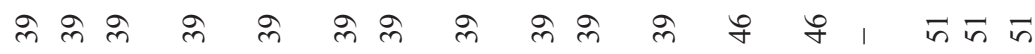

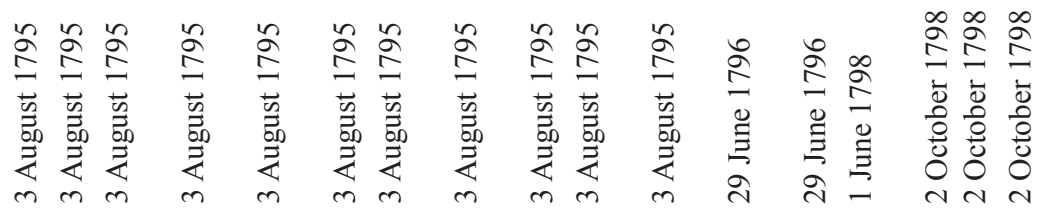

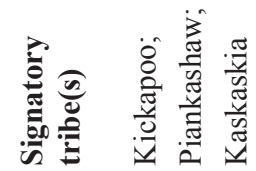

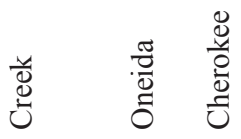

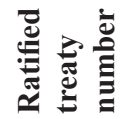

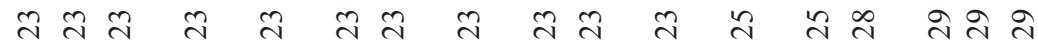




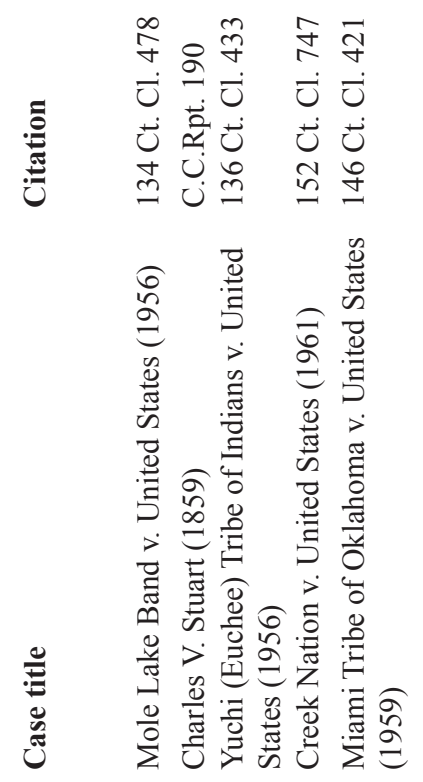

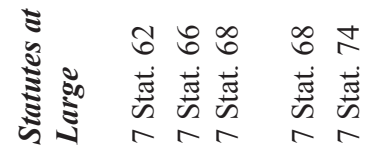

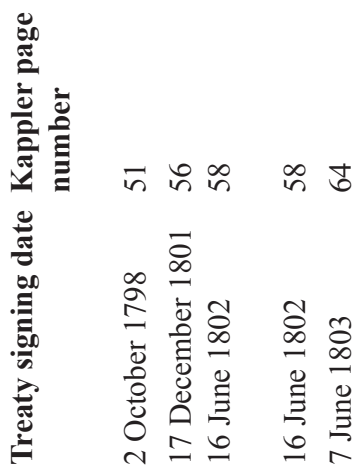

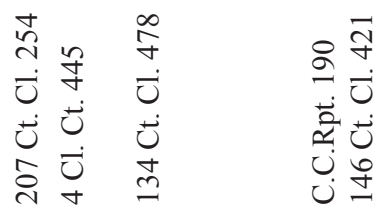
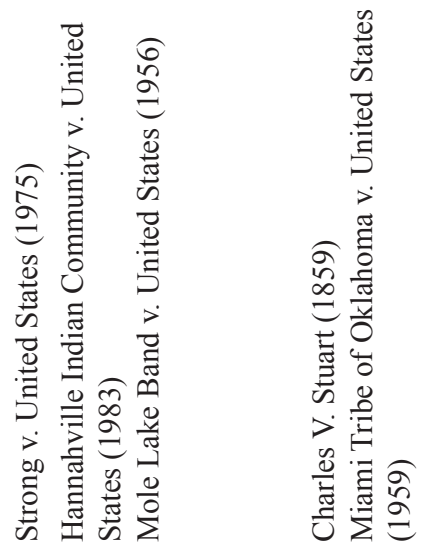

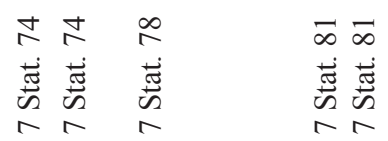

A t

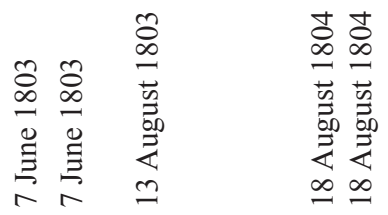
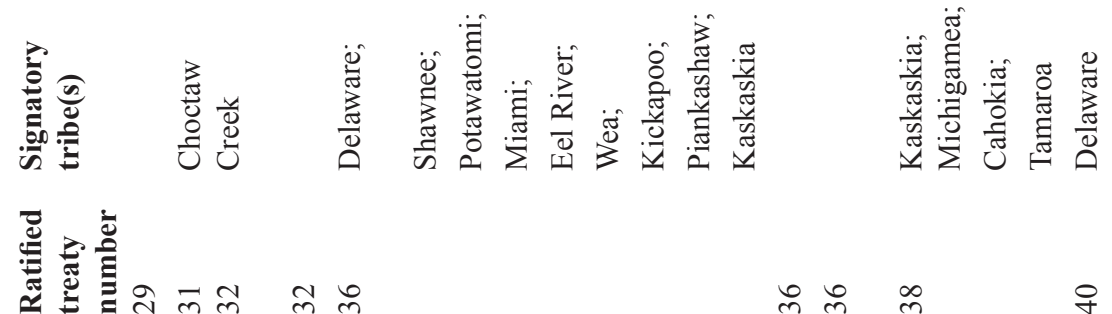

일 $\infty$ 웅 

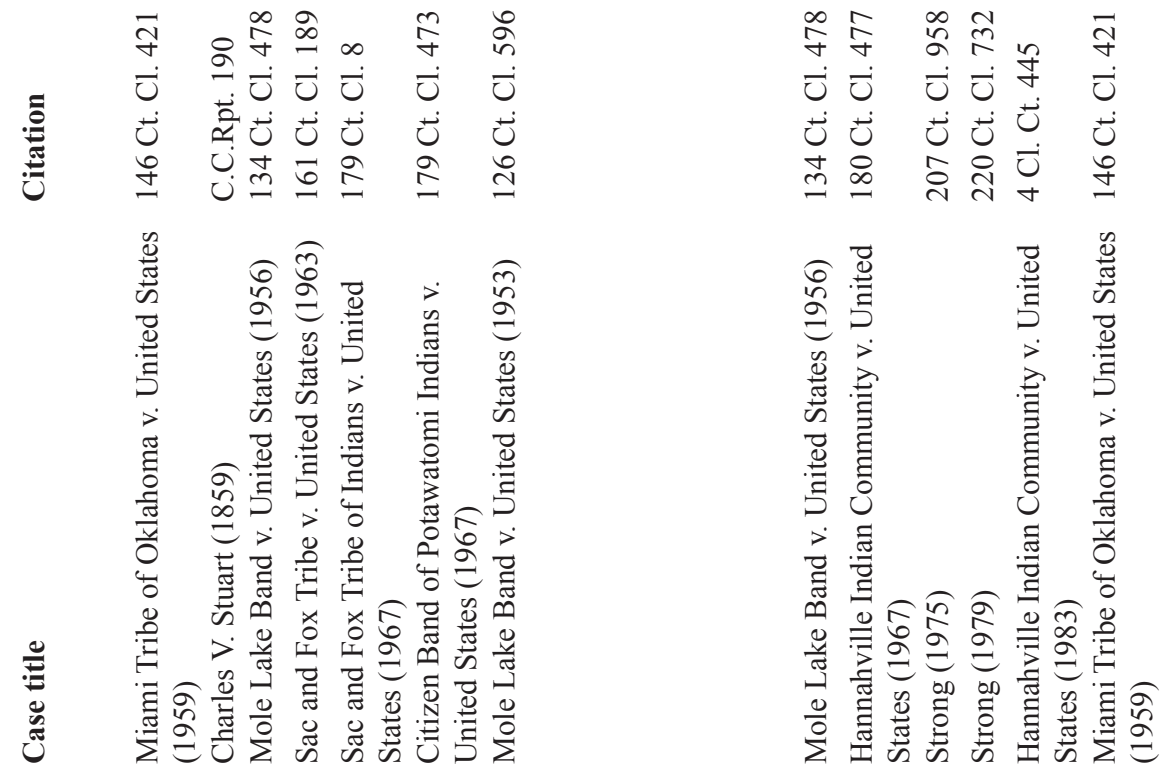

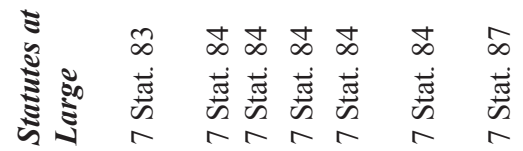

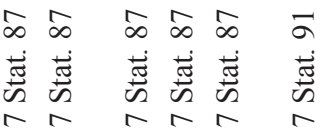

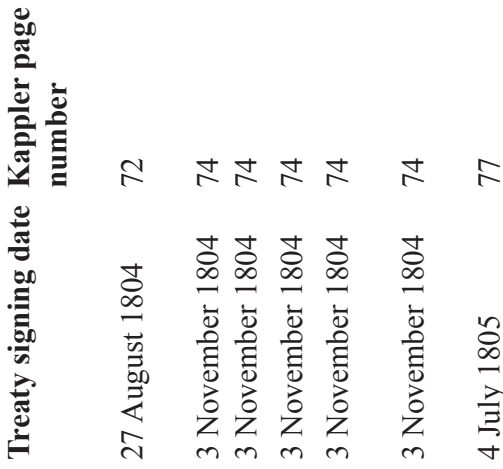

トลトลト

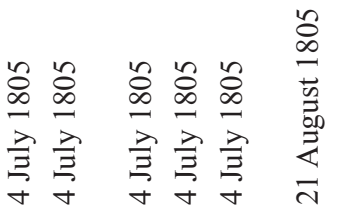
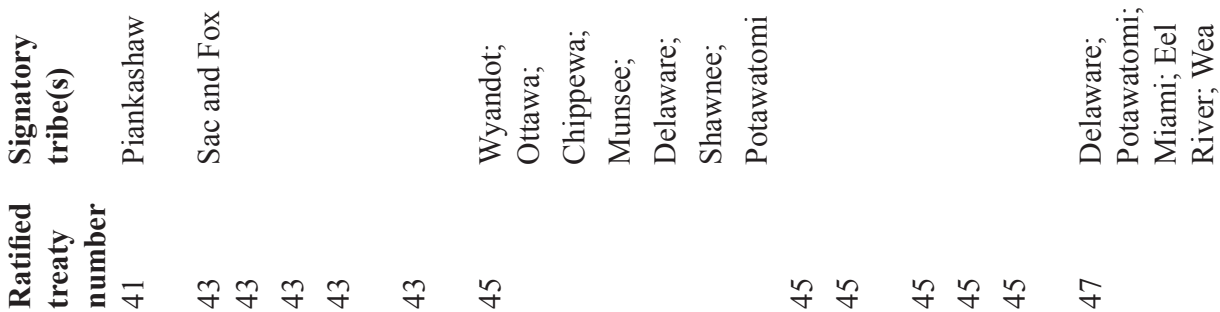

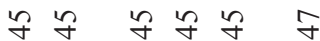




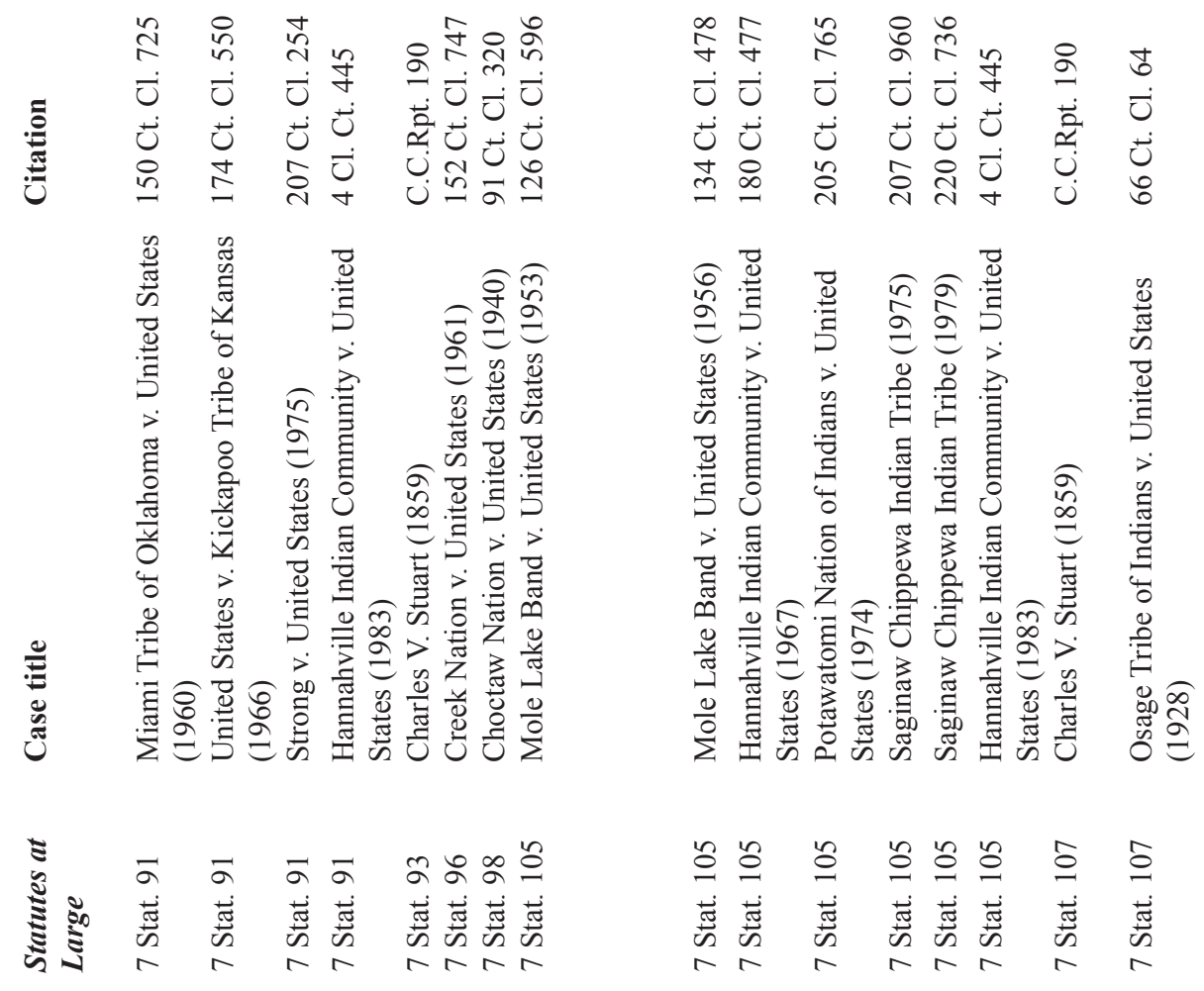

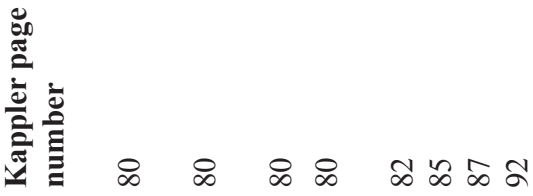

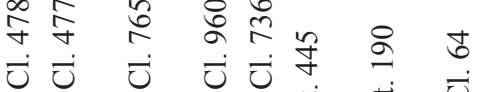

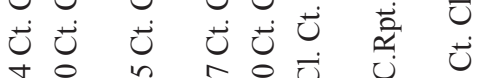

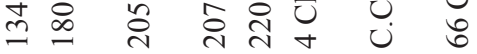

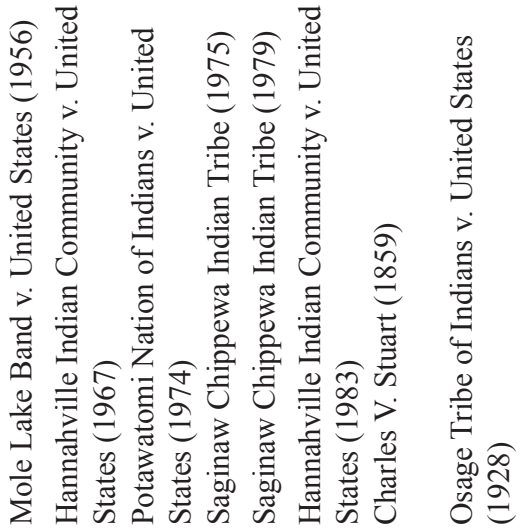

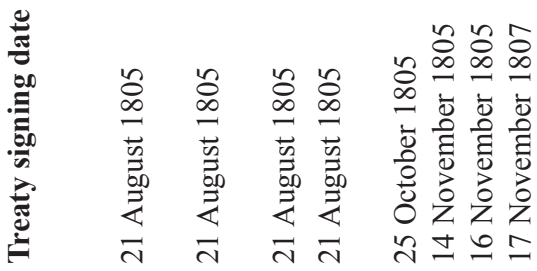

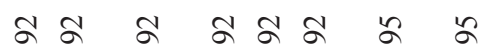

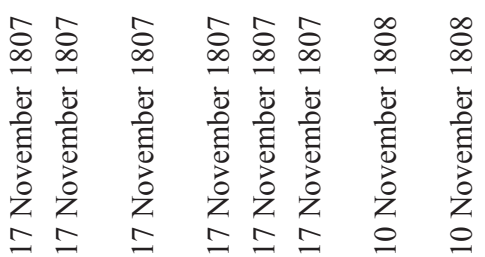

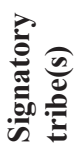

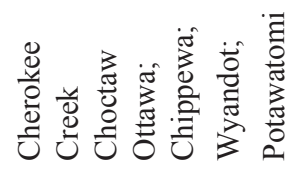

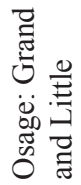

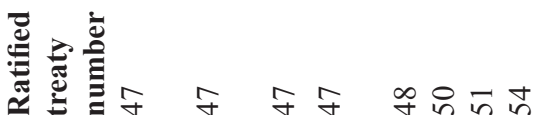

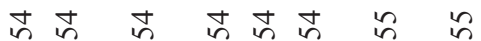




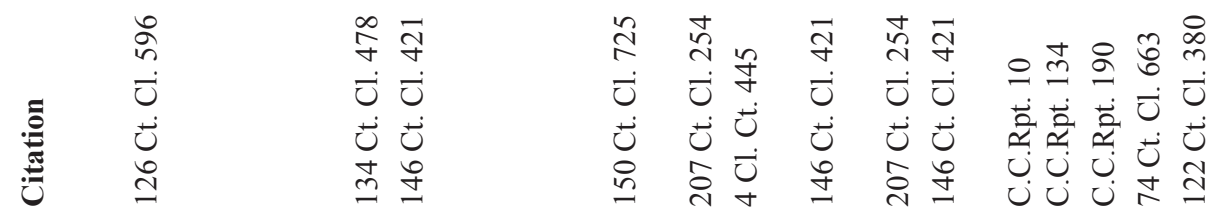
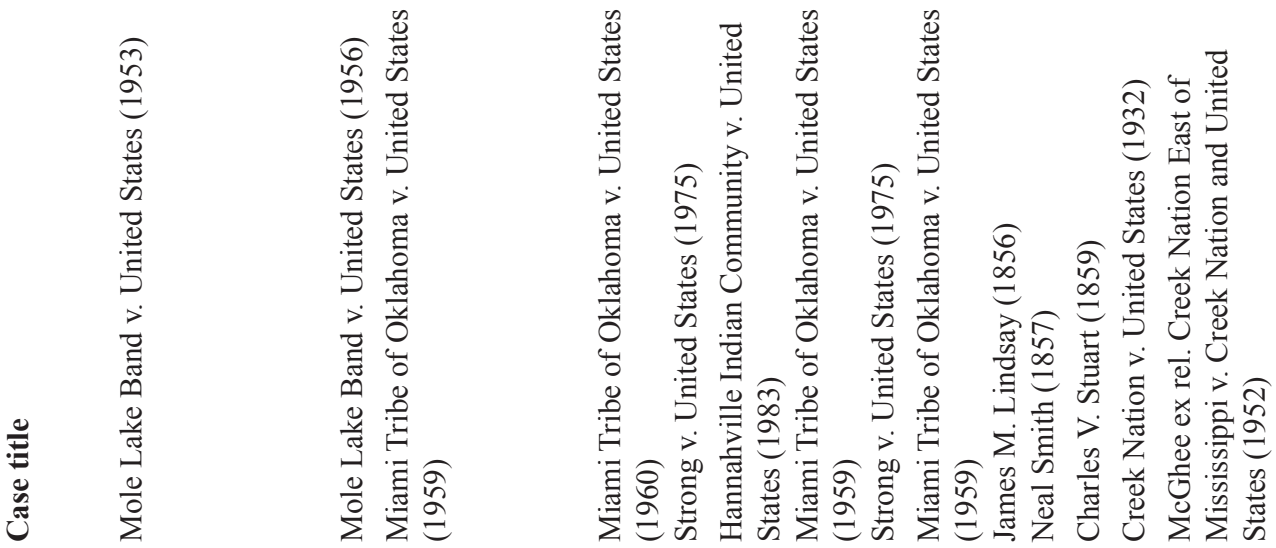

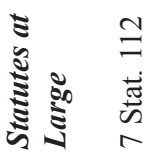

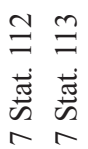

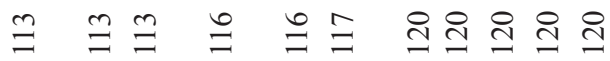

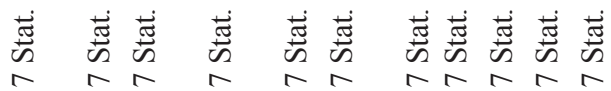
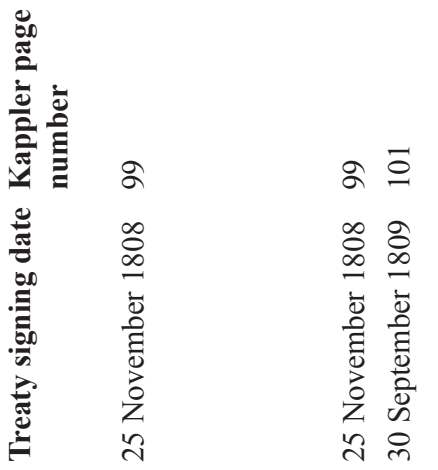

흐응 응 흥ㅎㅇ

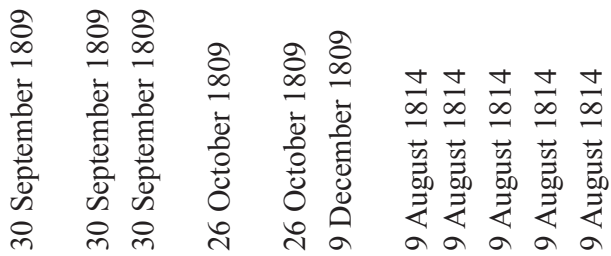

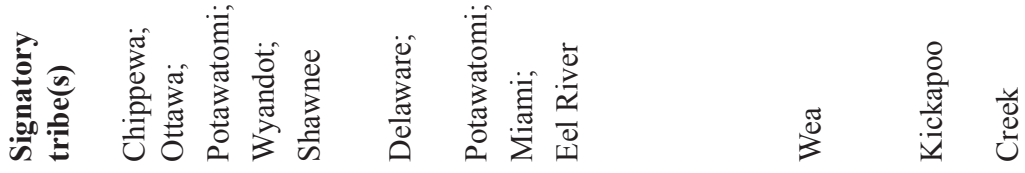

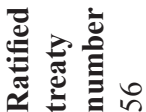

in

in in in in in $\overrightarrow{0} \vec{\sigma} \vec{\sigma} \vec{\sigma} \vec{\sigma}$ 

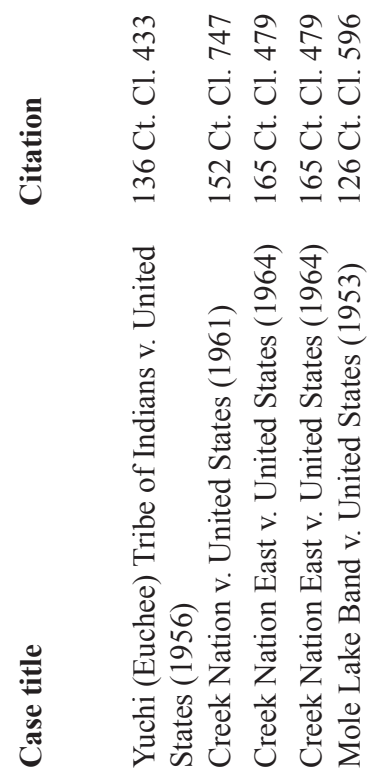

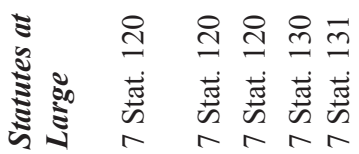

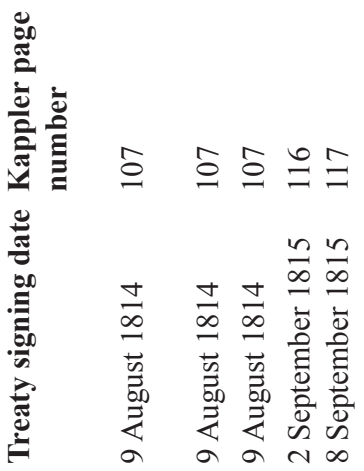

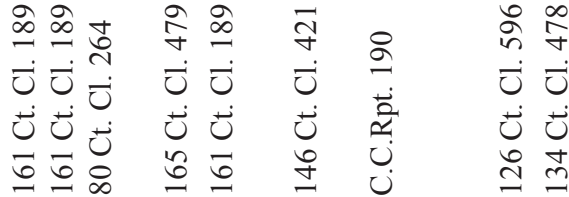

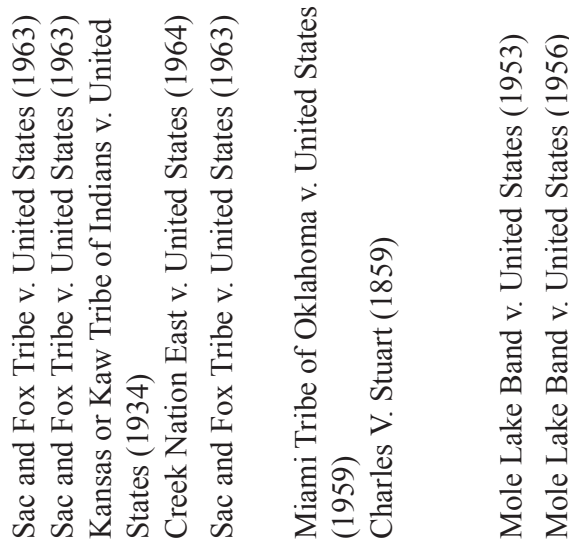

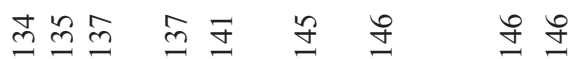

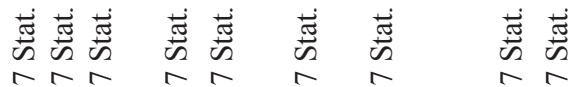

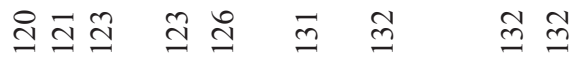

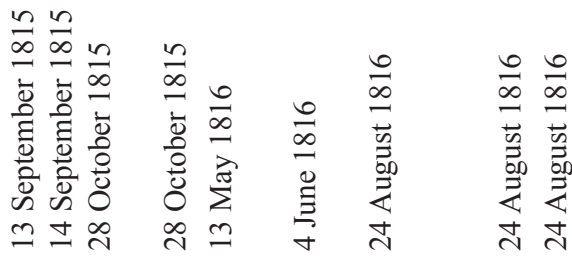

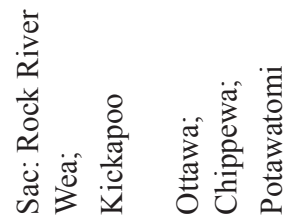

$\tilde{\infty}$ 


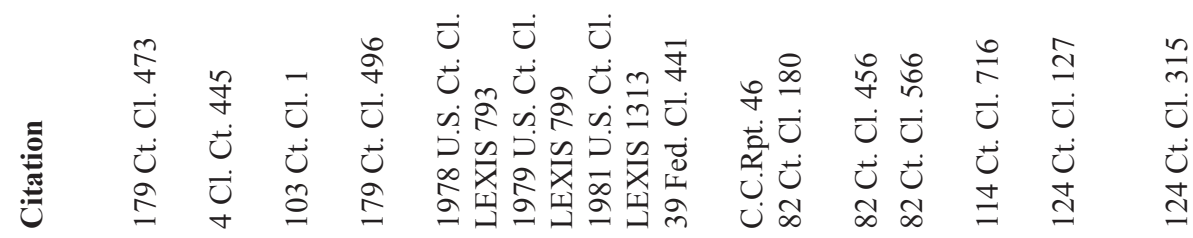

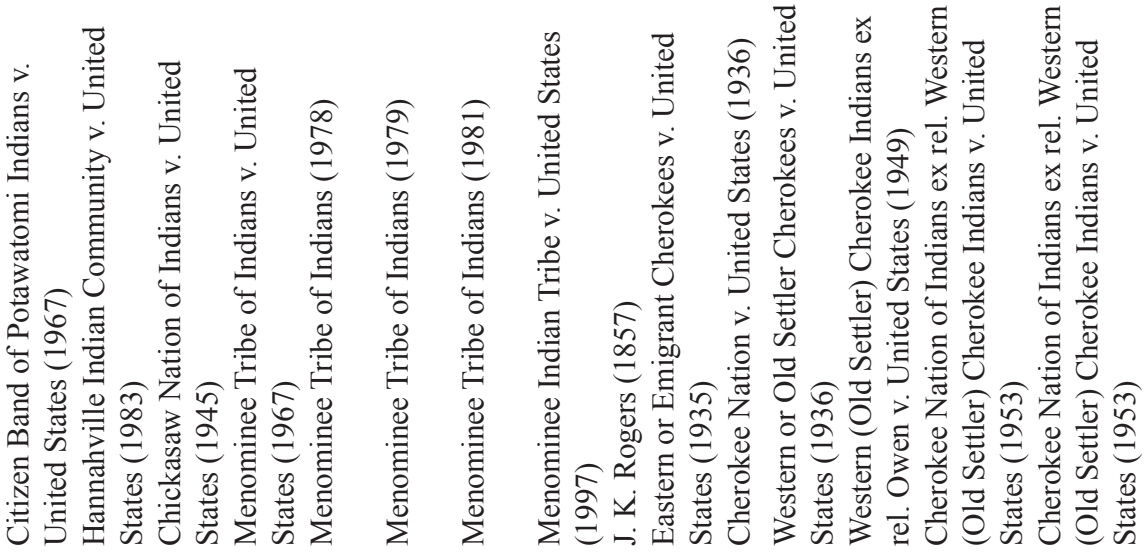

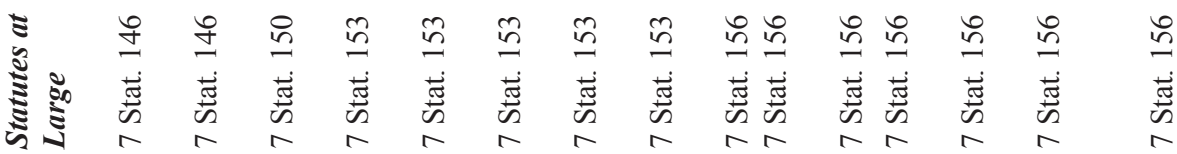

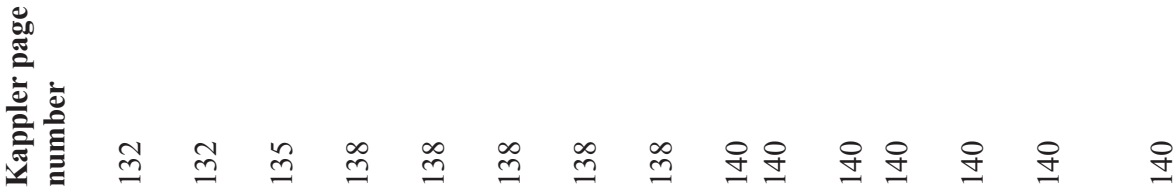

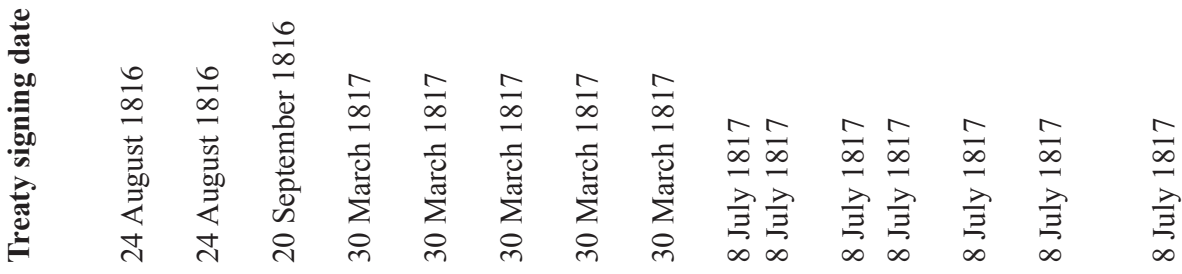
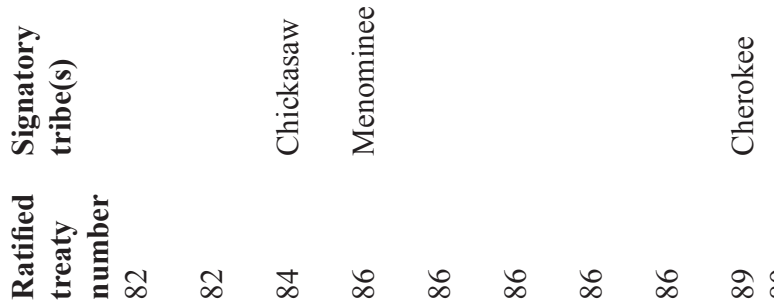

$\begin{array}{lllllllllllllll}1 & \infty & \infty & \infty & \infty & \infty & 0 & 0 & \infty & \infty & \infty & \infty & \infty & \infty & \infty\end{array}$ 


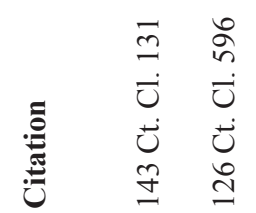

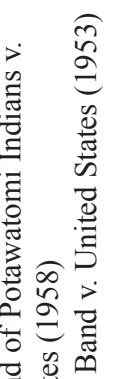

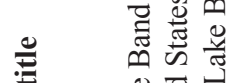

U

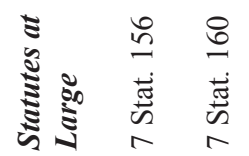

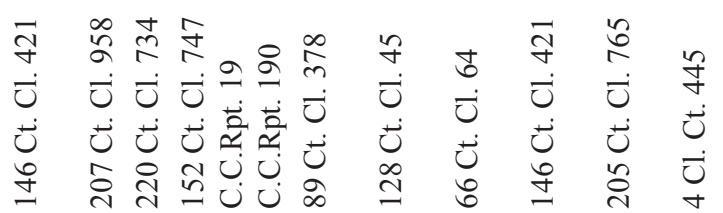

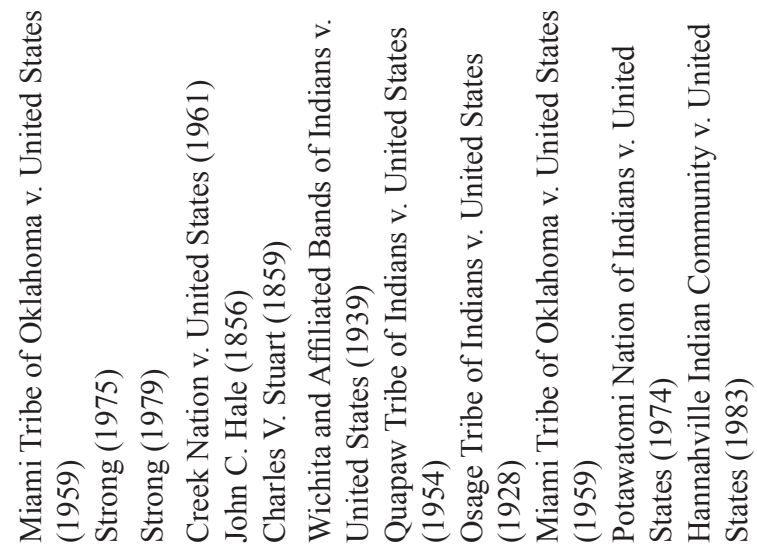

-

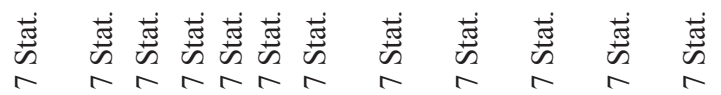

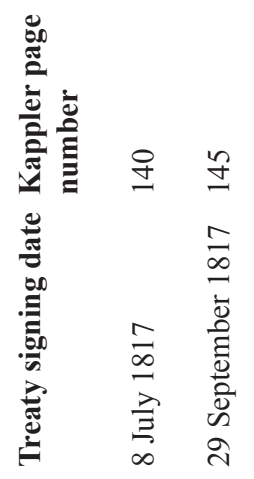

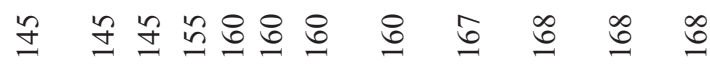

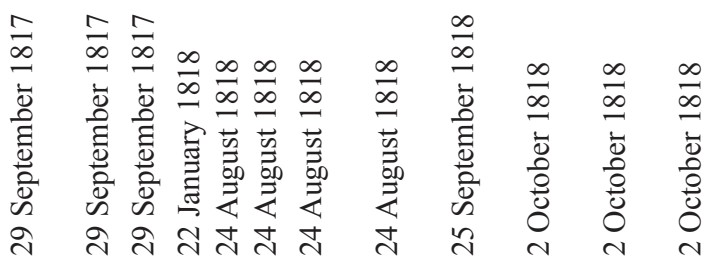
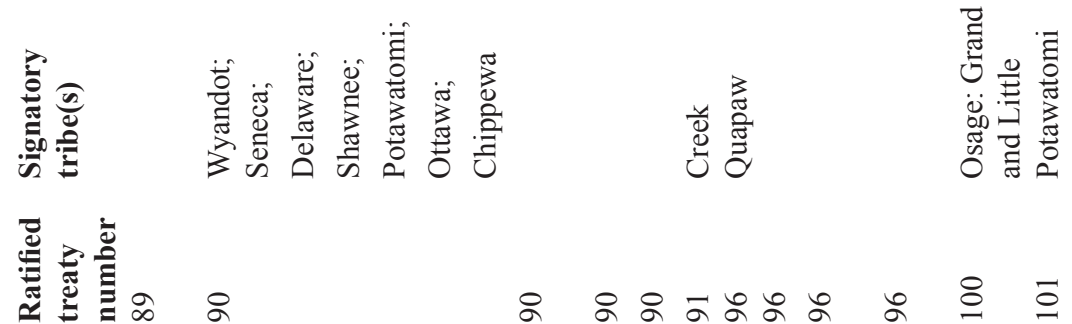

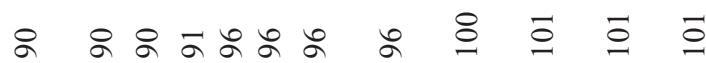




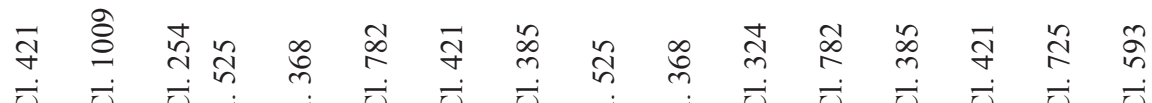

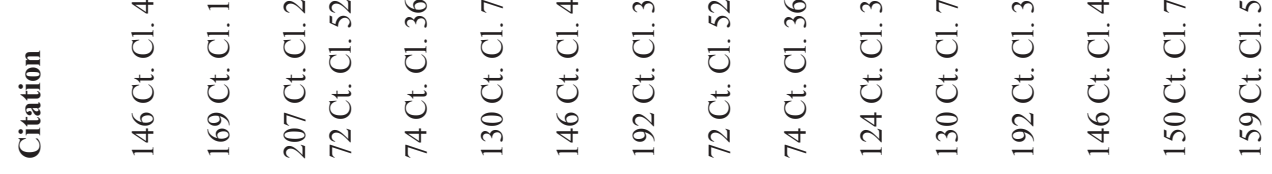

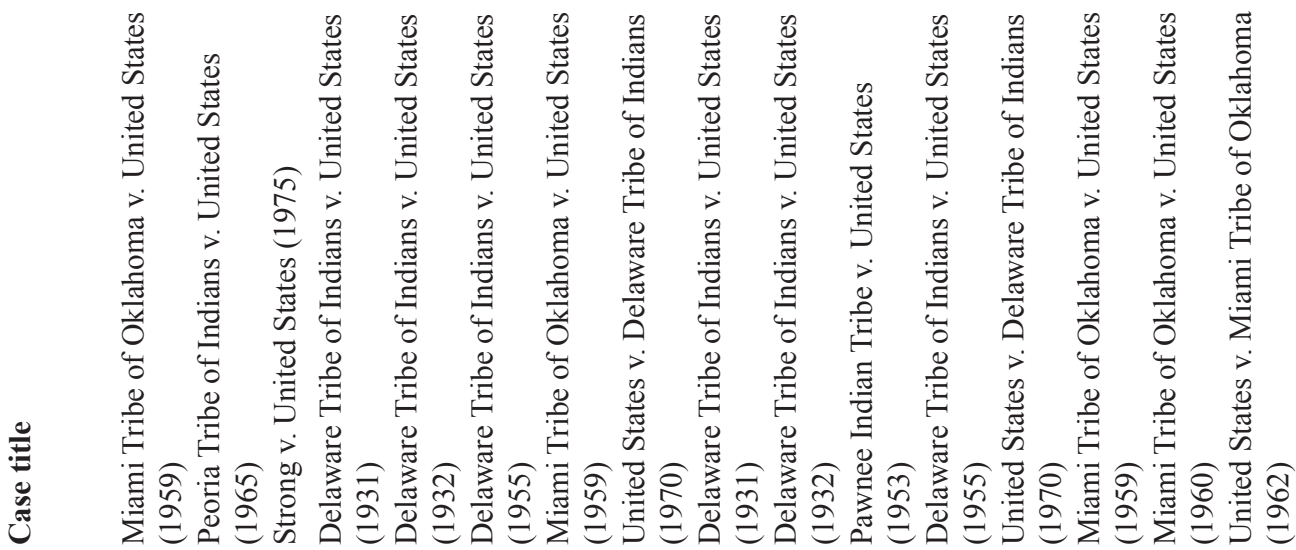

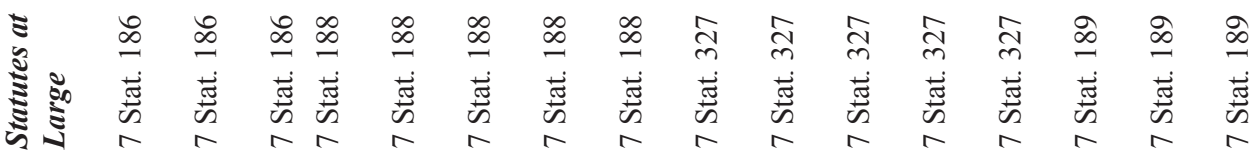

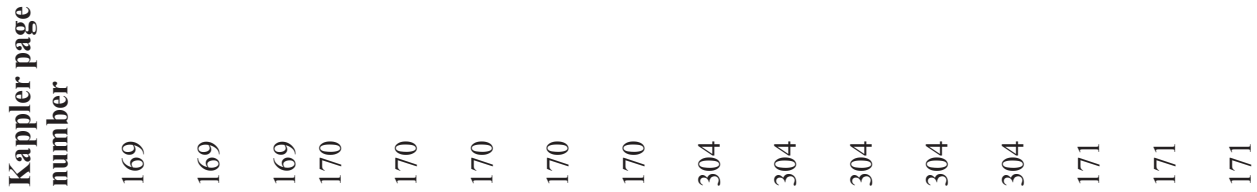

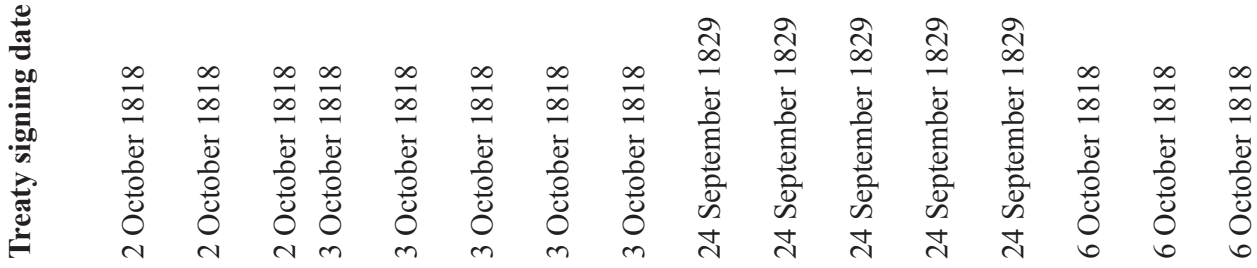<smiles>[Te][Te]=C1CC1</smiles>

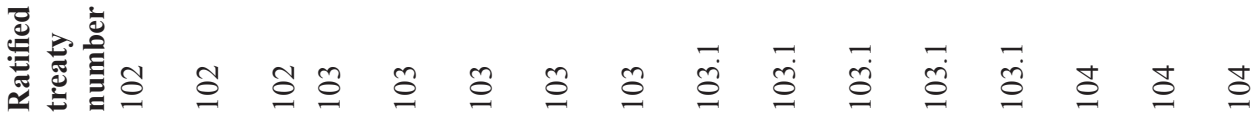



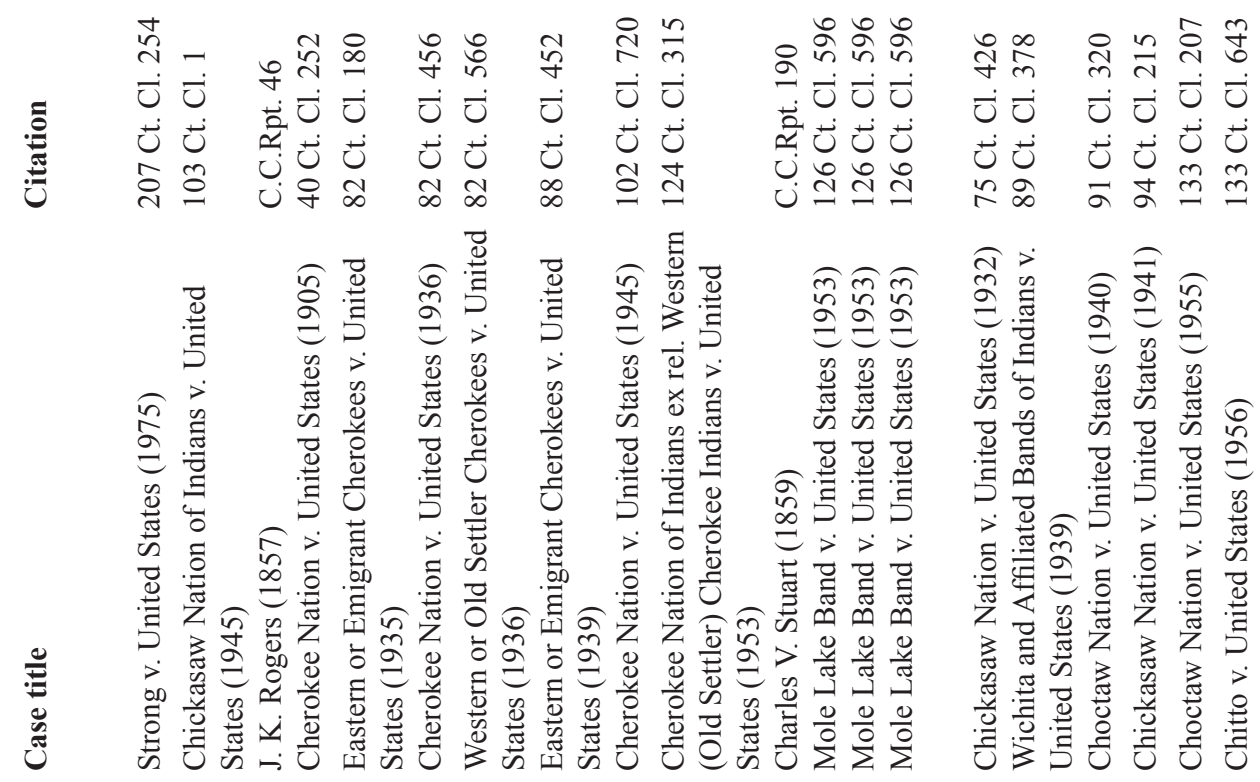

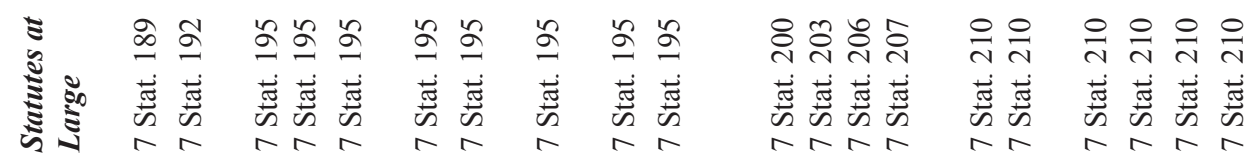

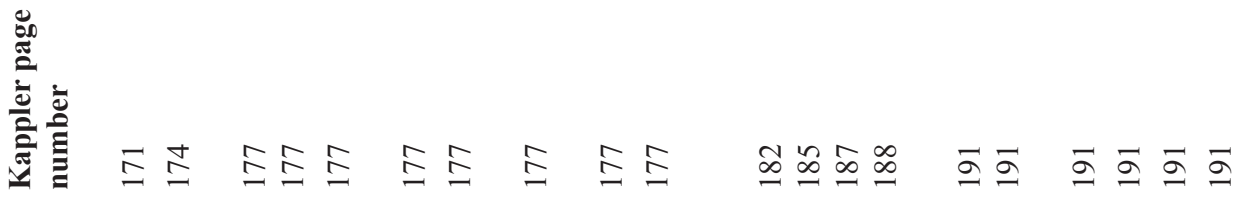

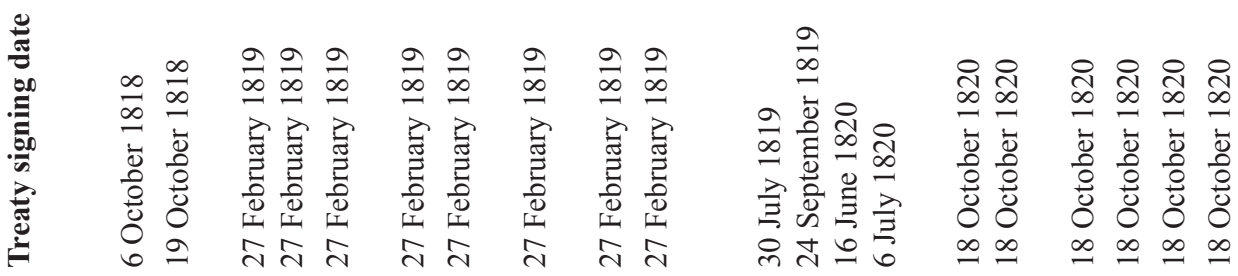
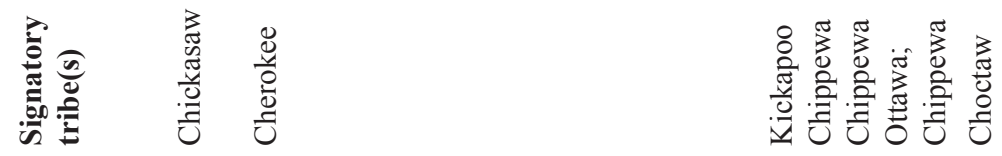

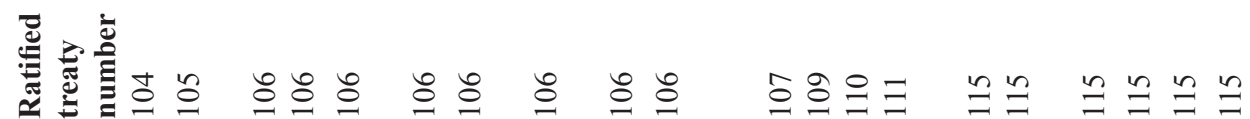




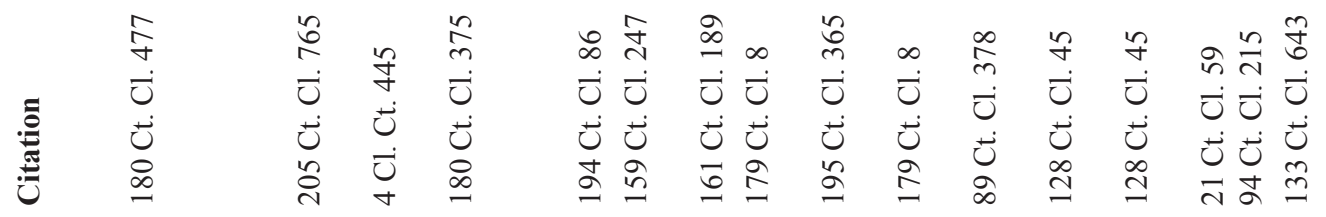

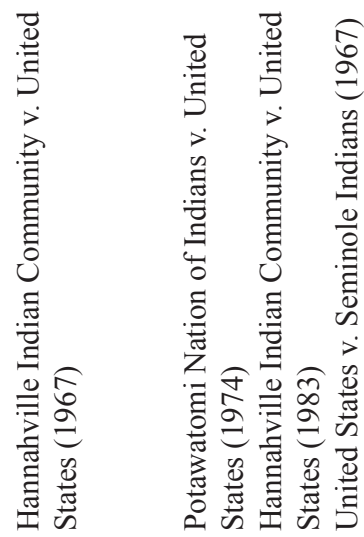

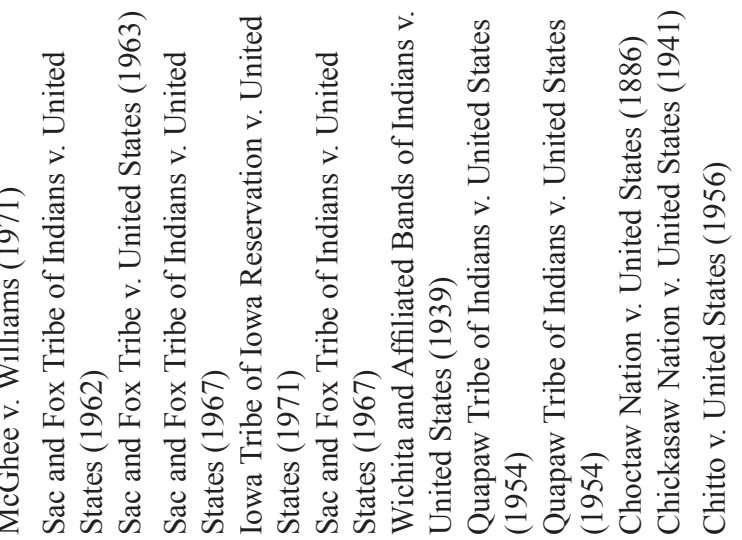

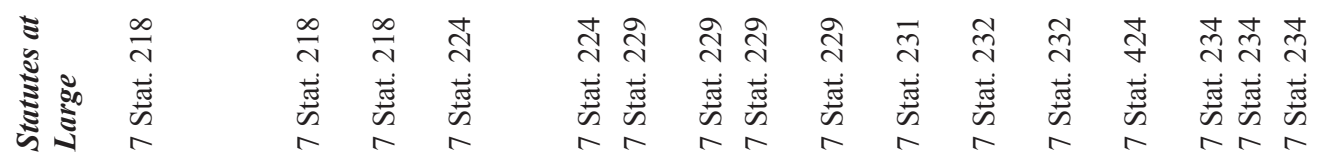

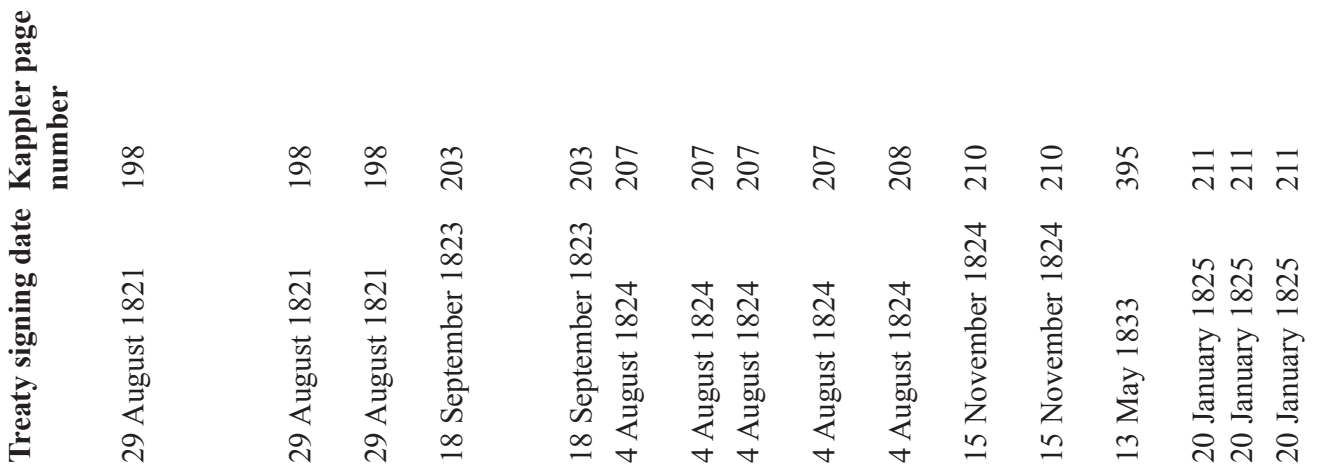

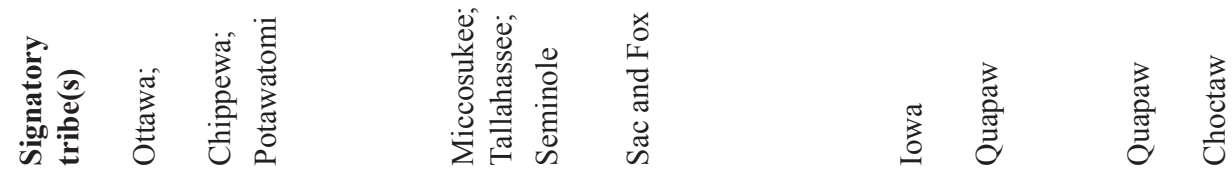

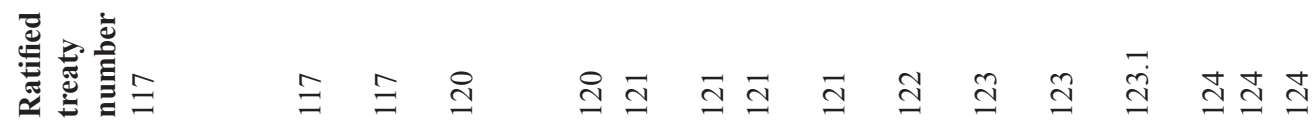




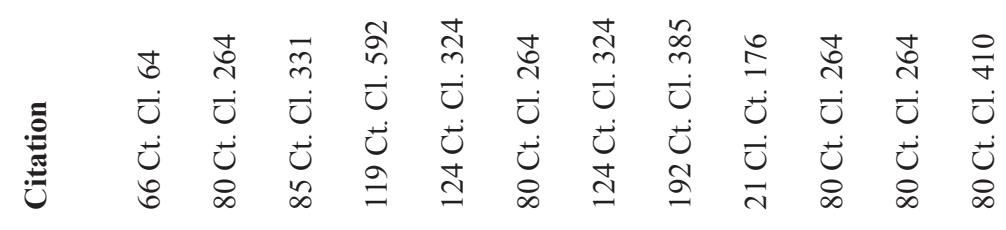

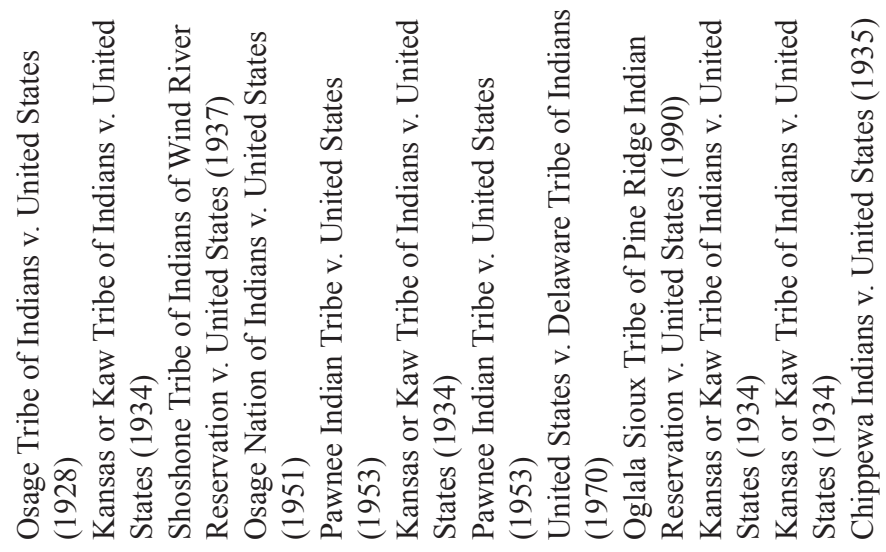

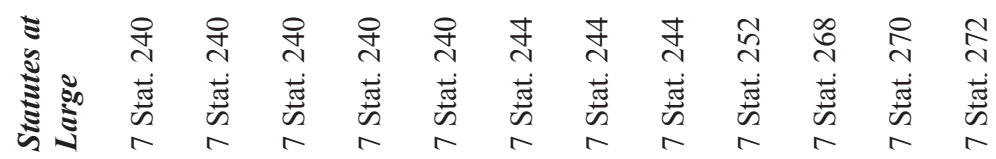

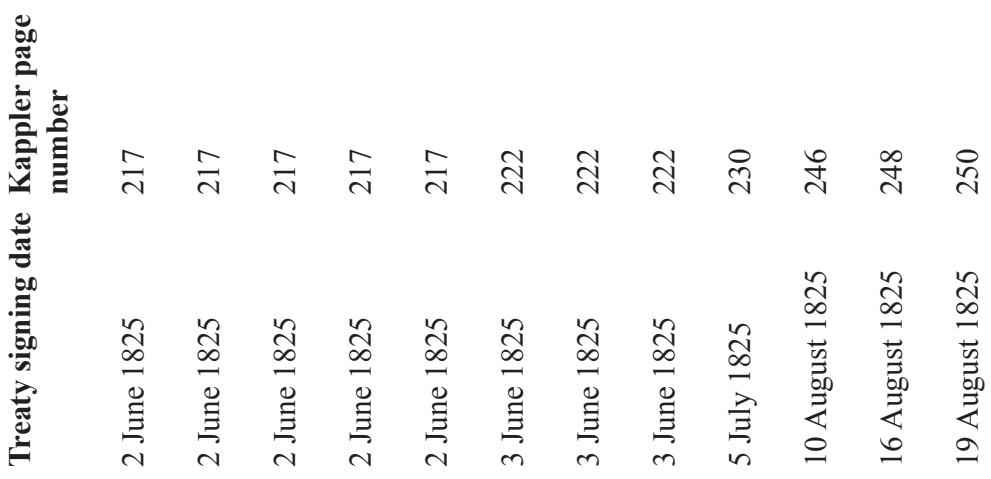

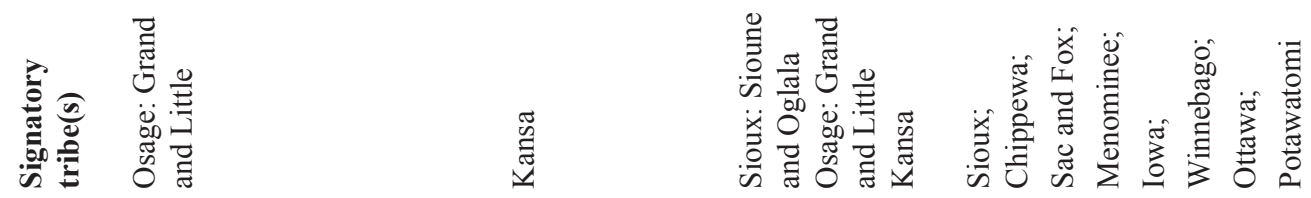

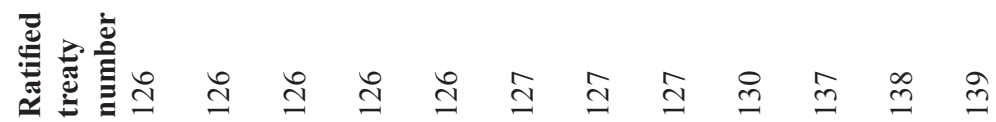




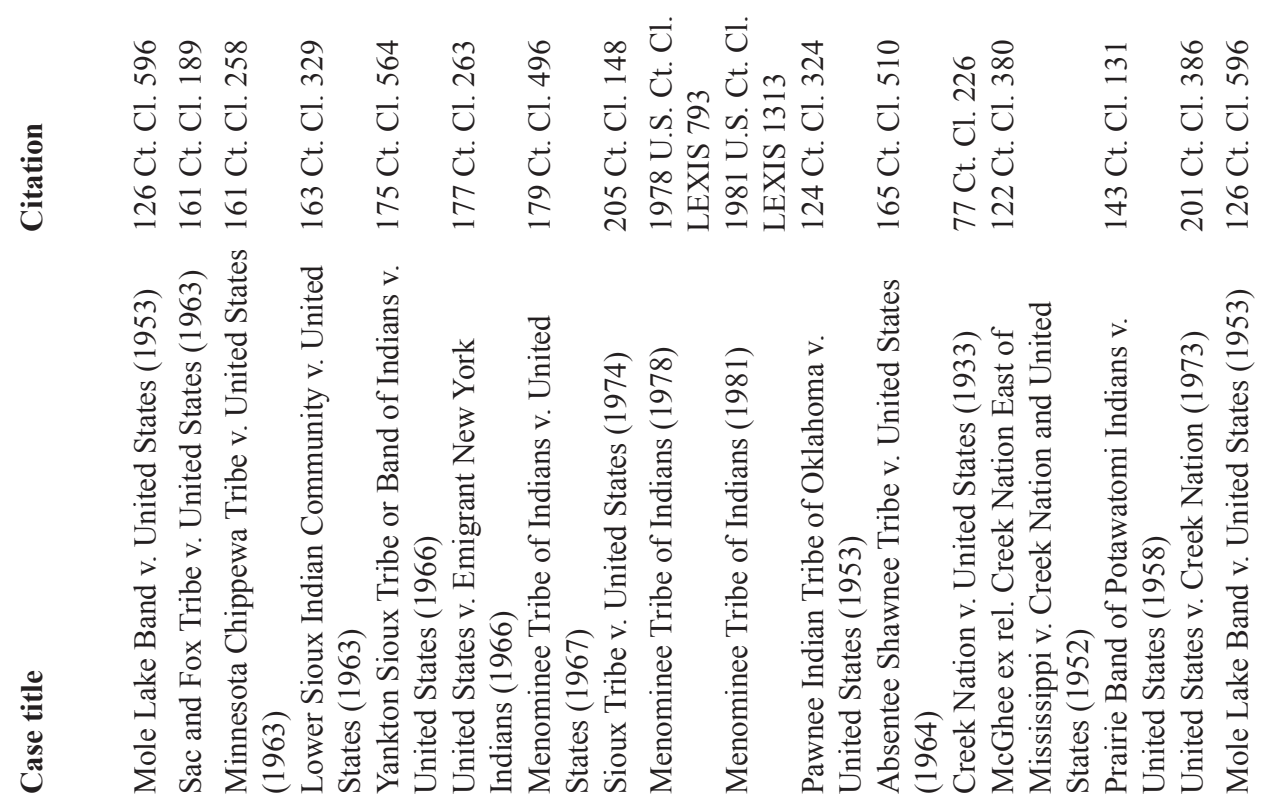

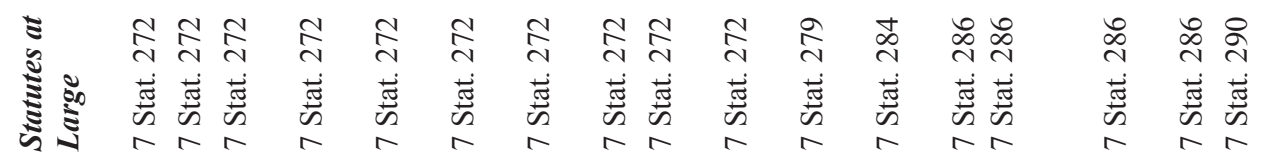

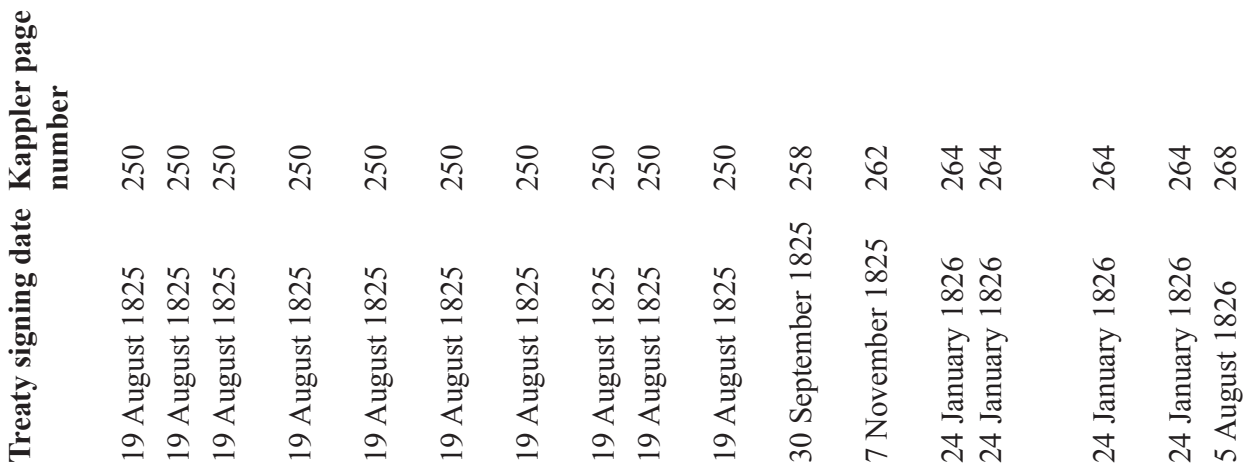

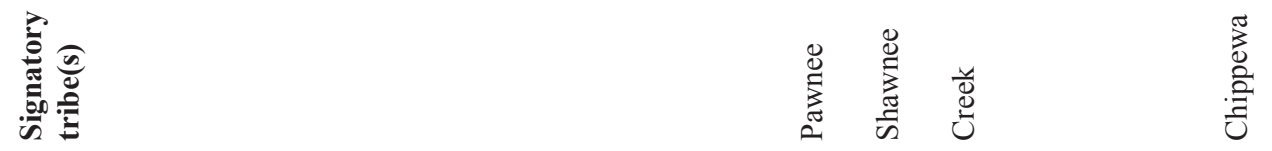

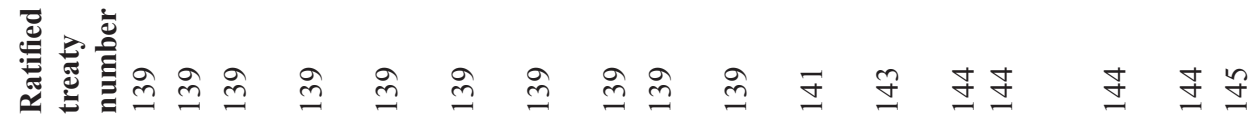




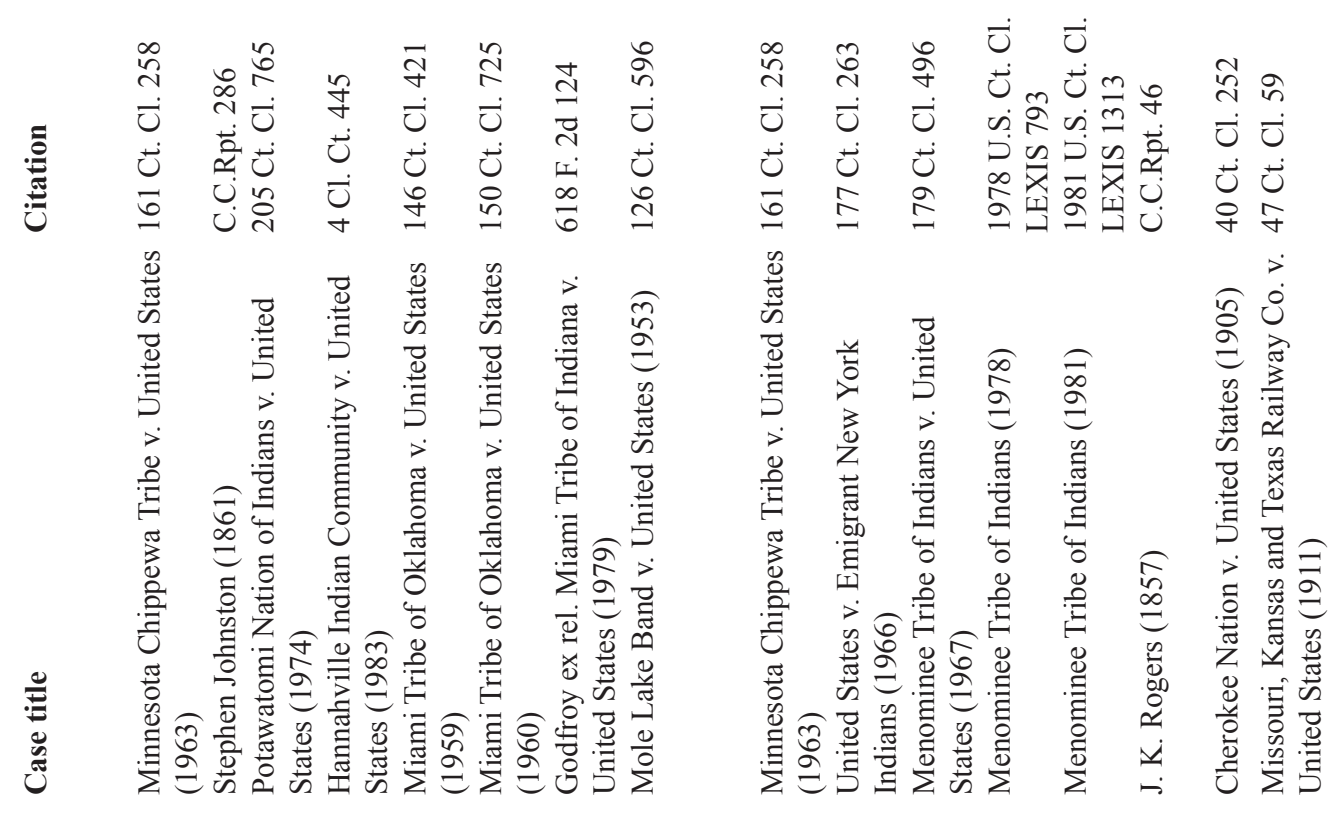

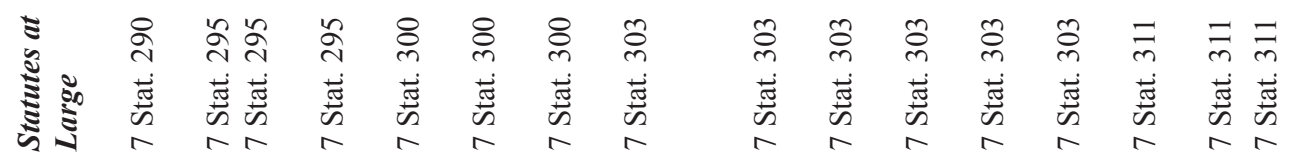

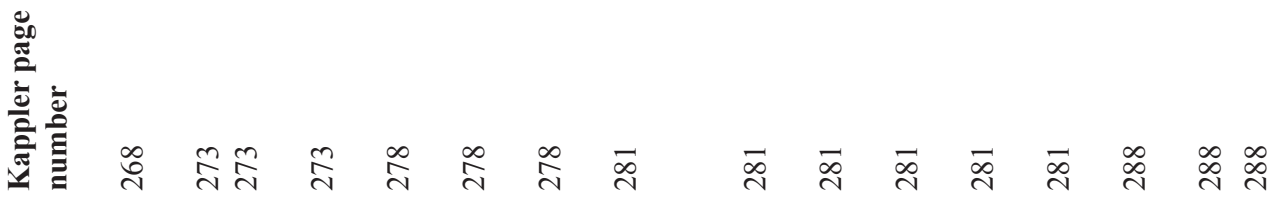

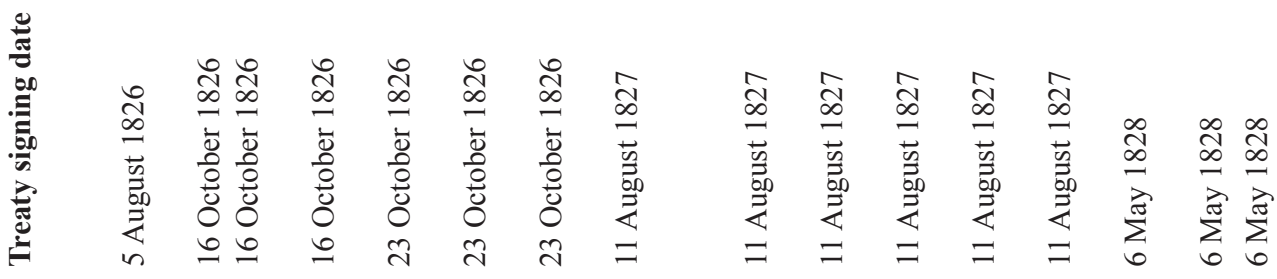

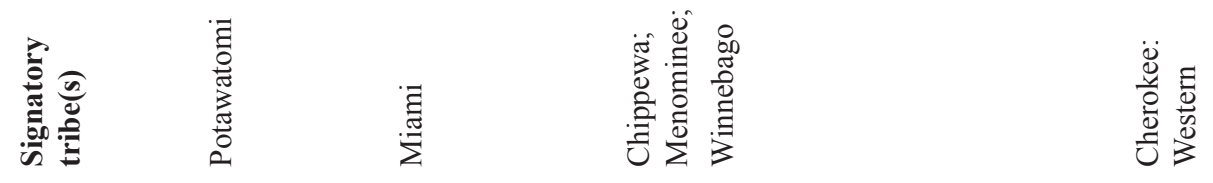

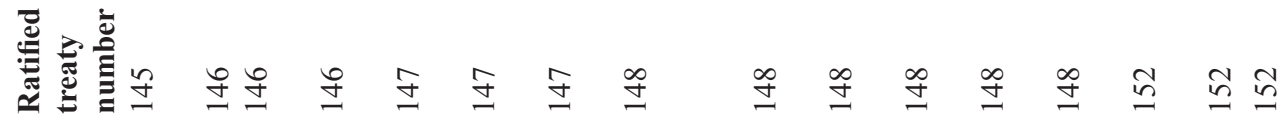




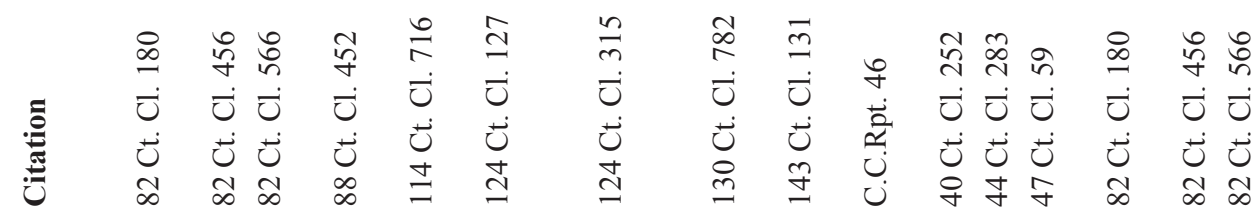

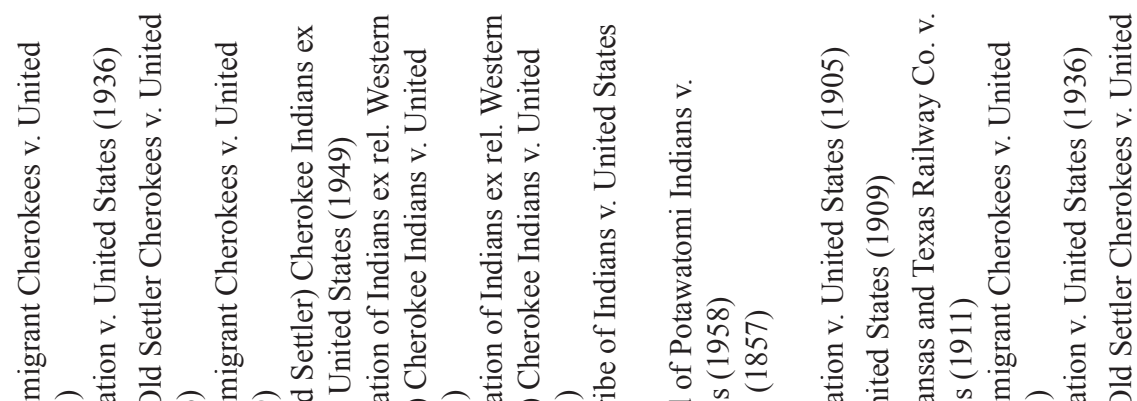

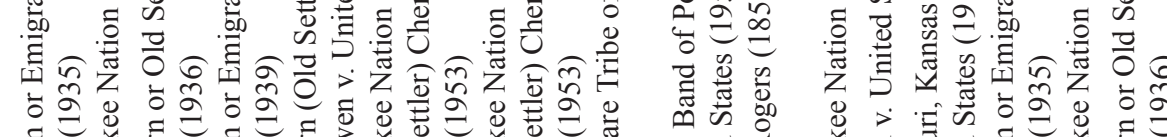

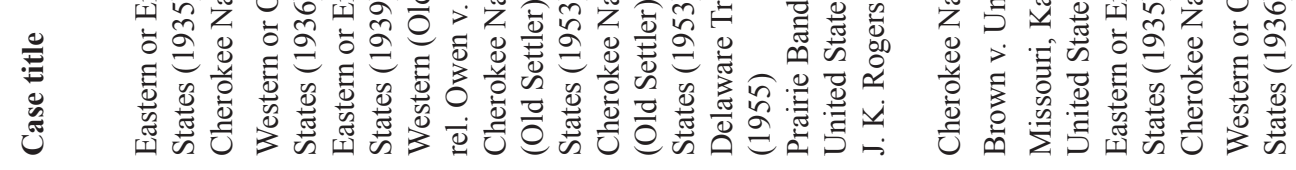

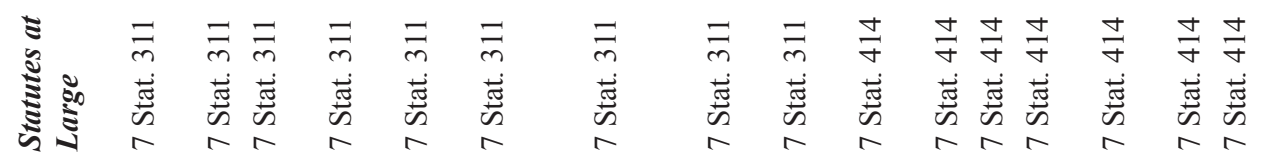

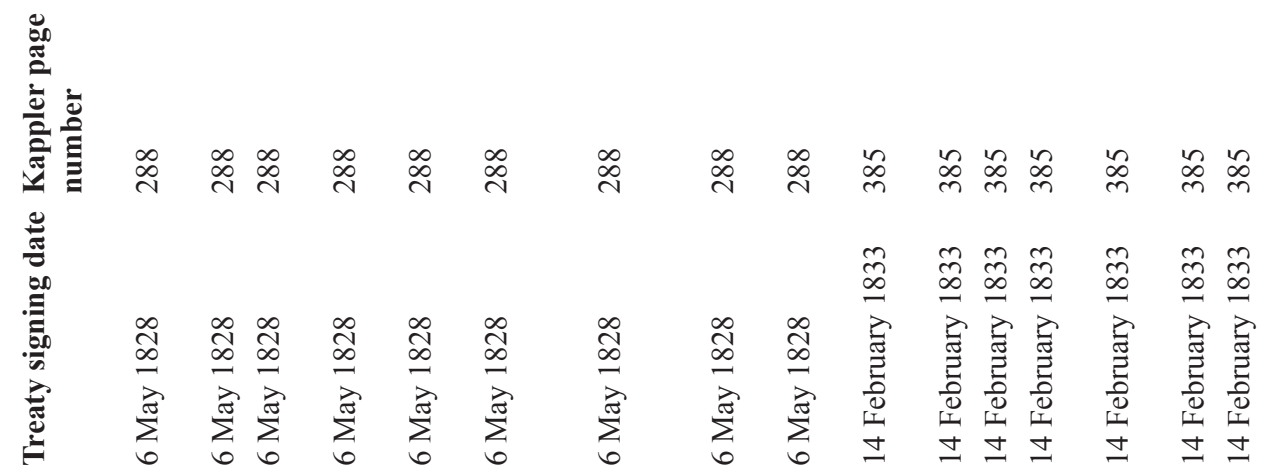
总

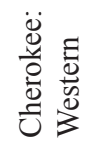

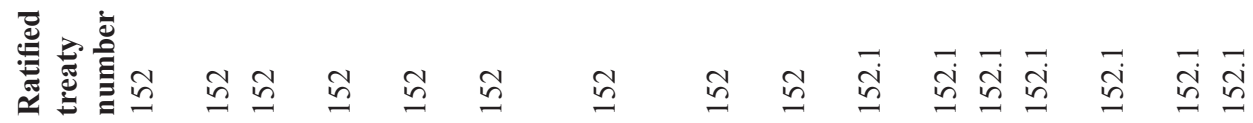




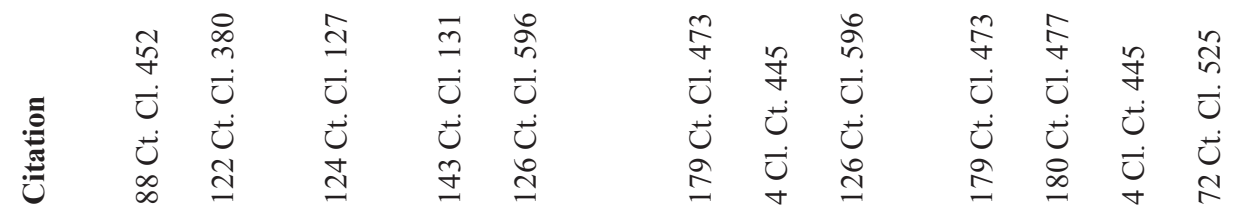
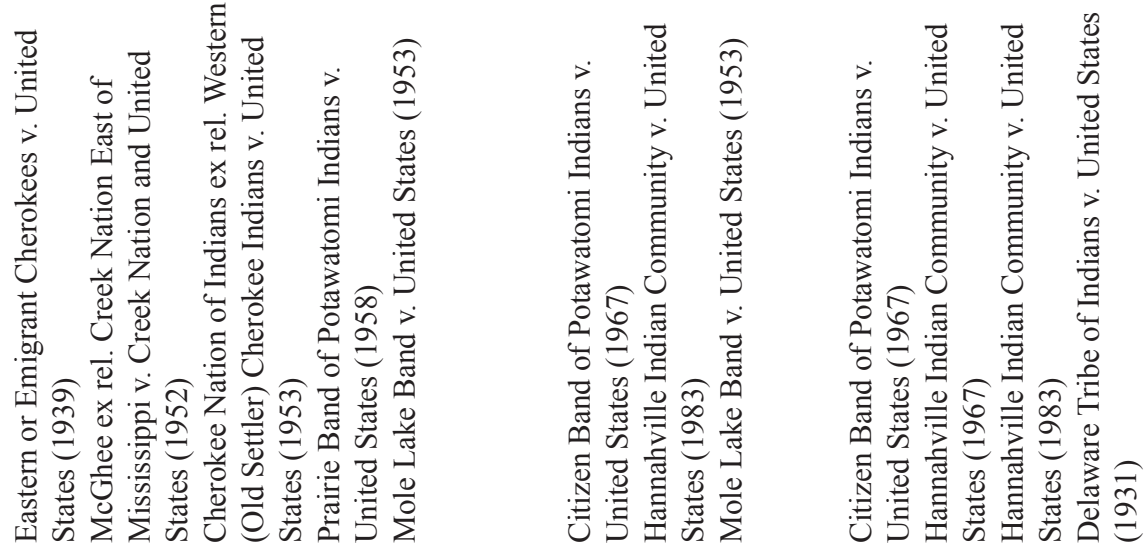

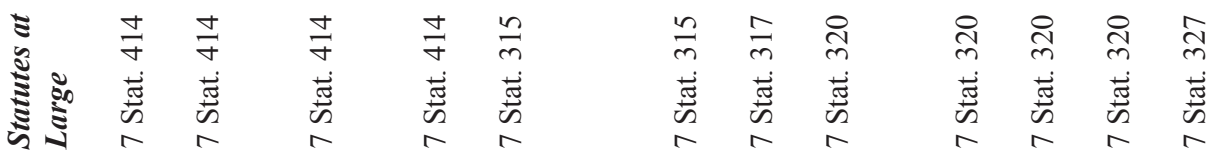
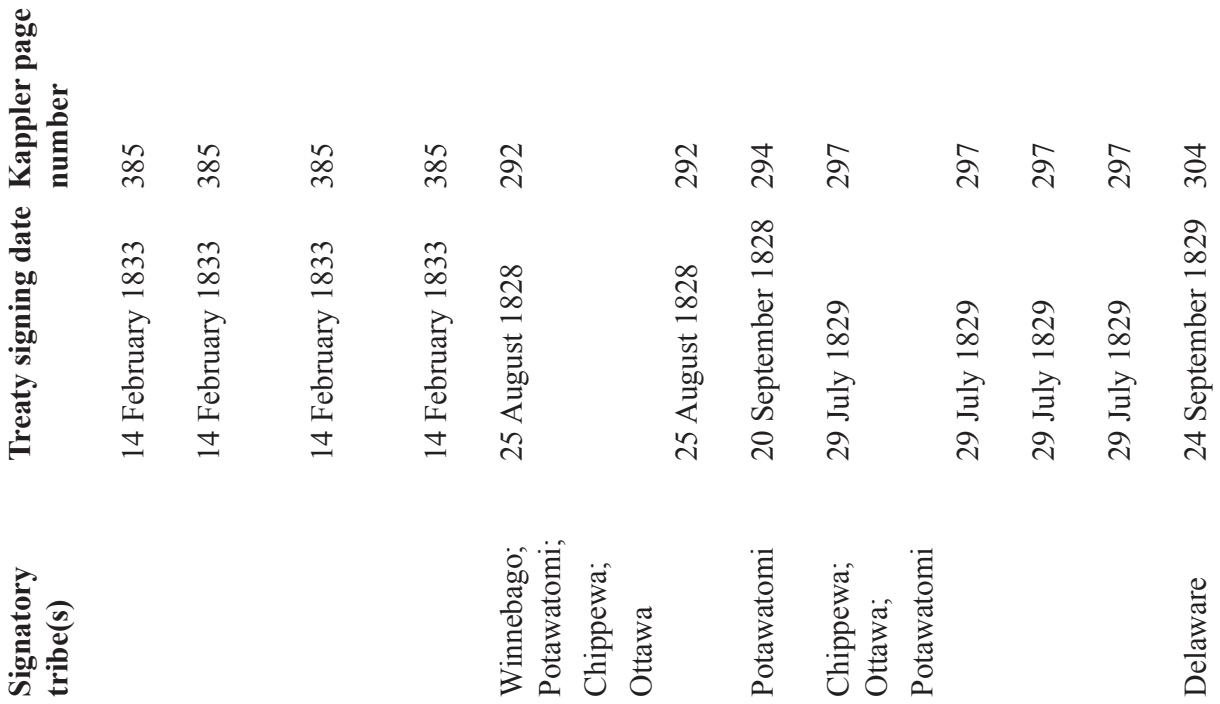

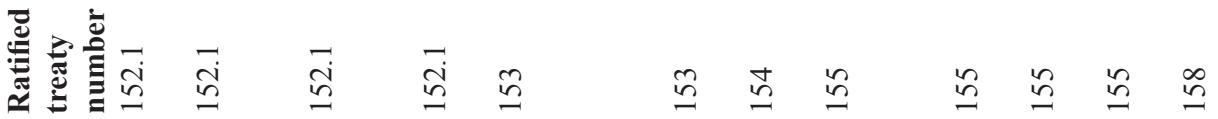




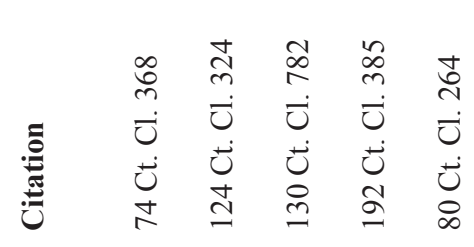

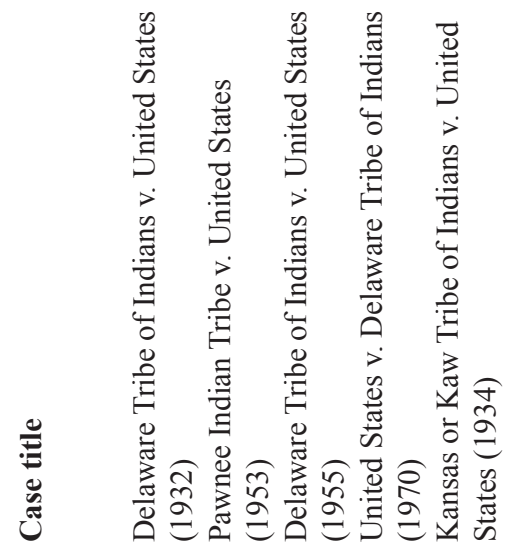

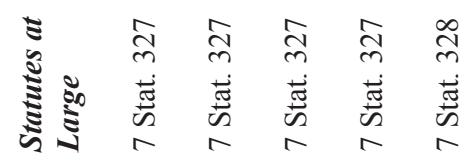

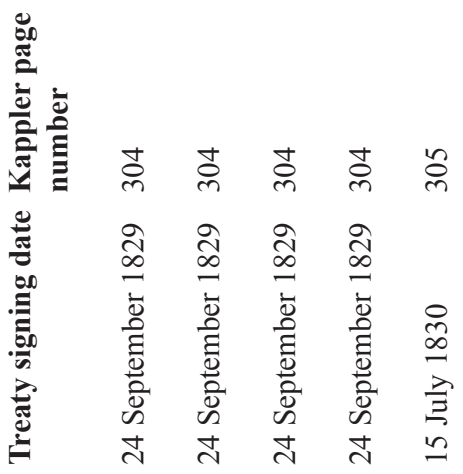

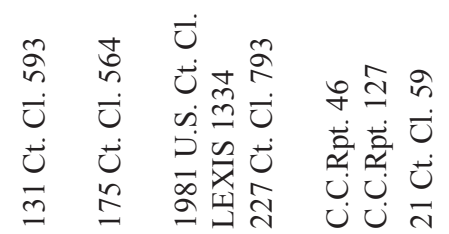

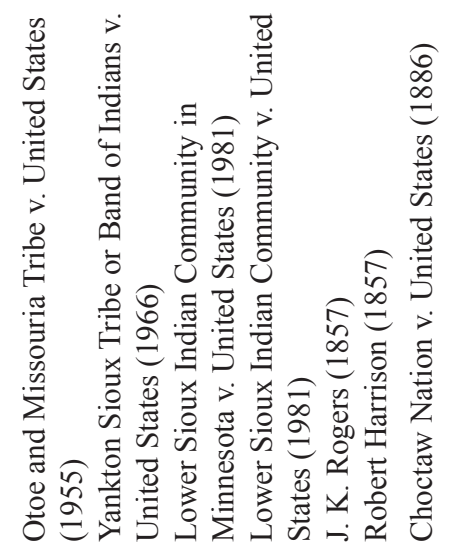

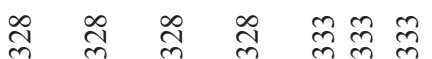

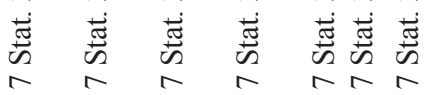

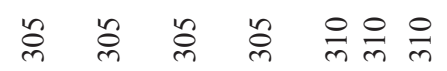

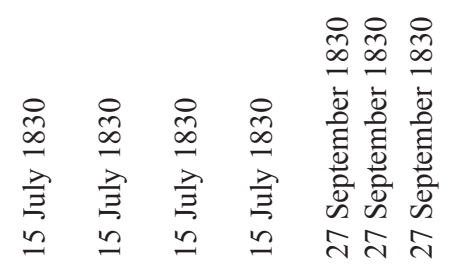

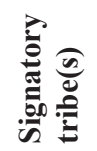

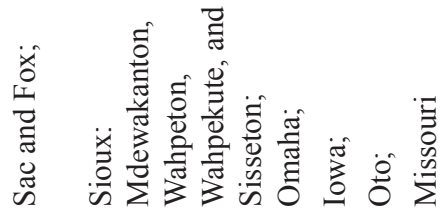




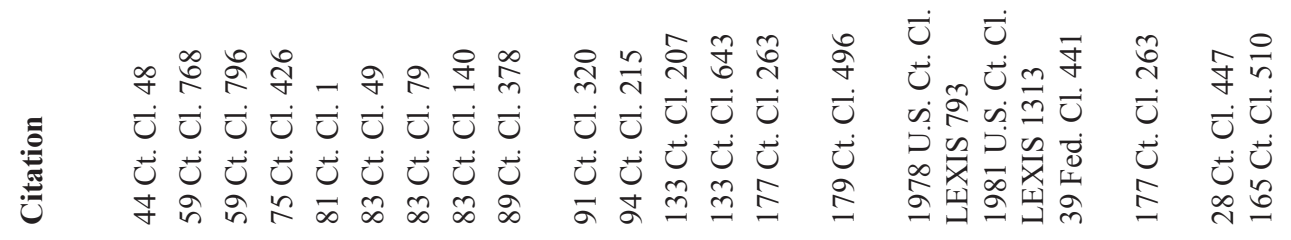

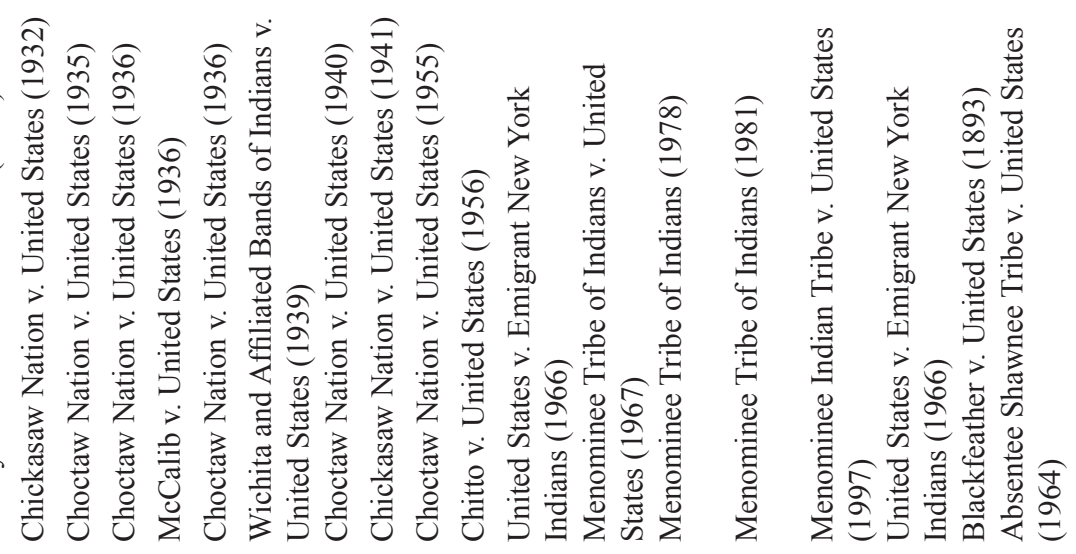

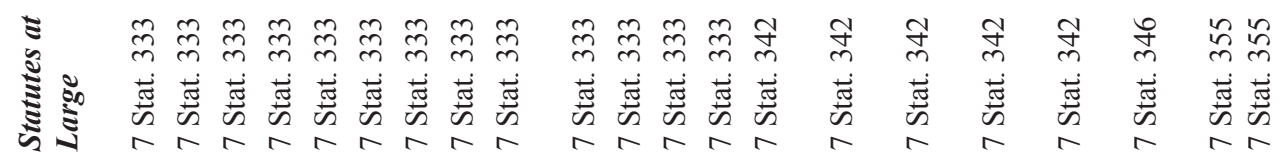

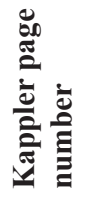

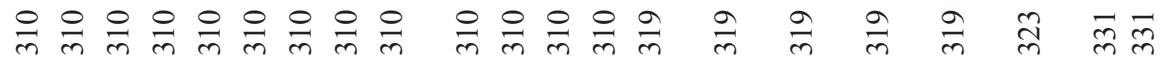

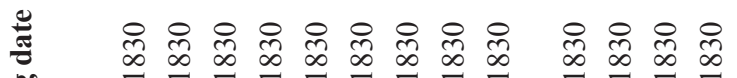

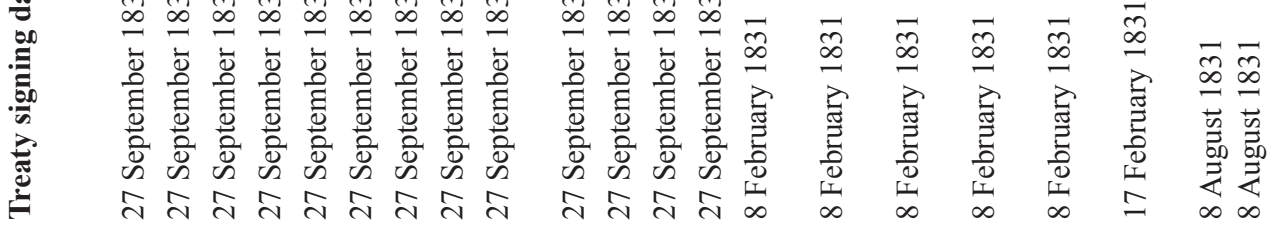

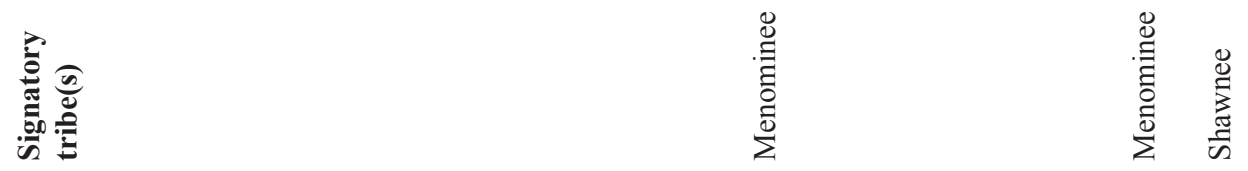

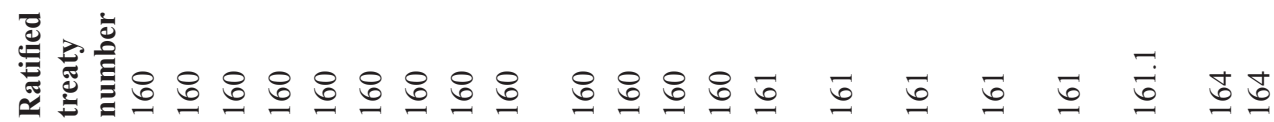




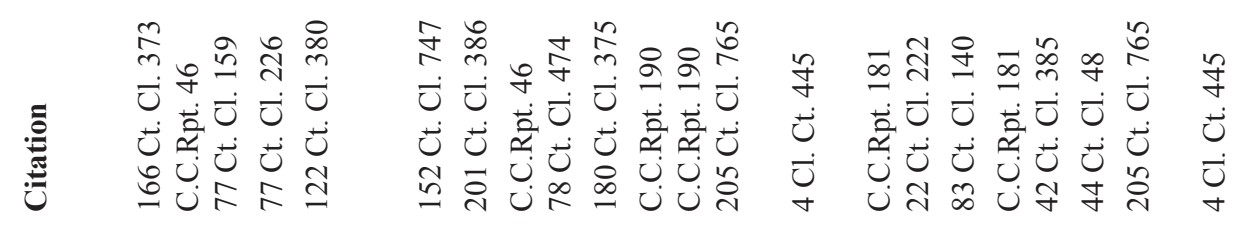

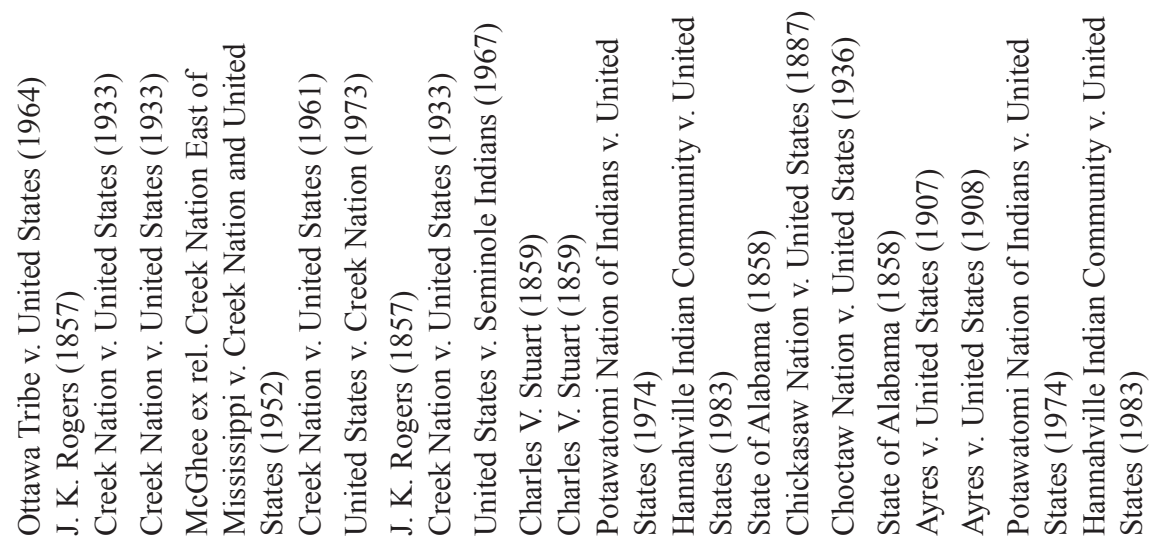

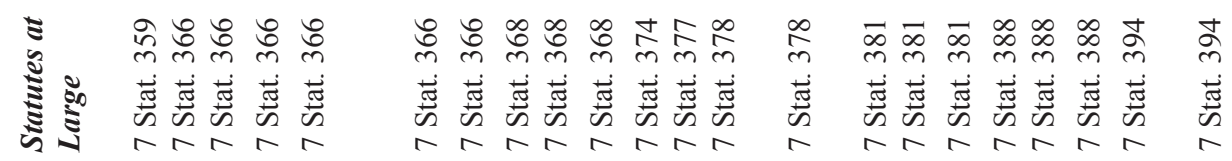
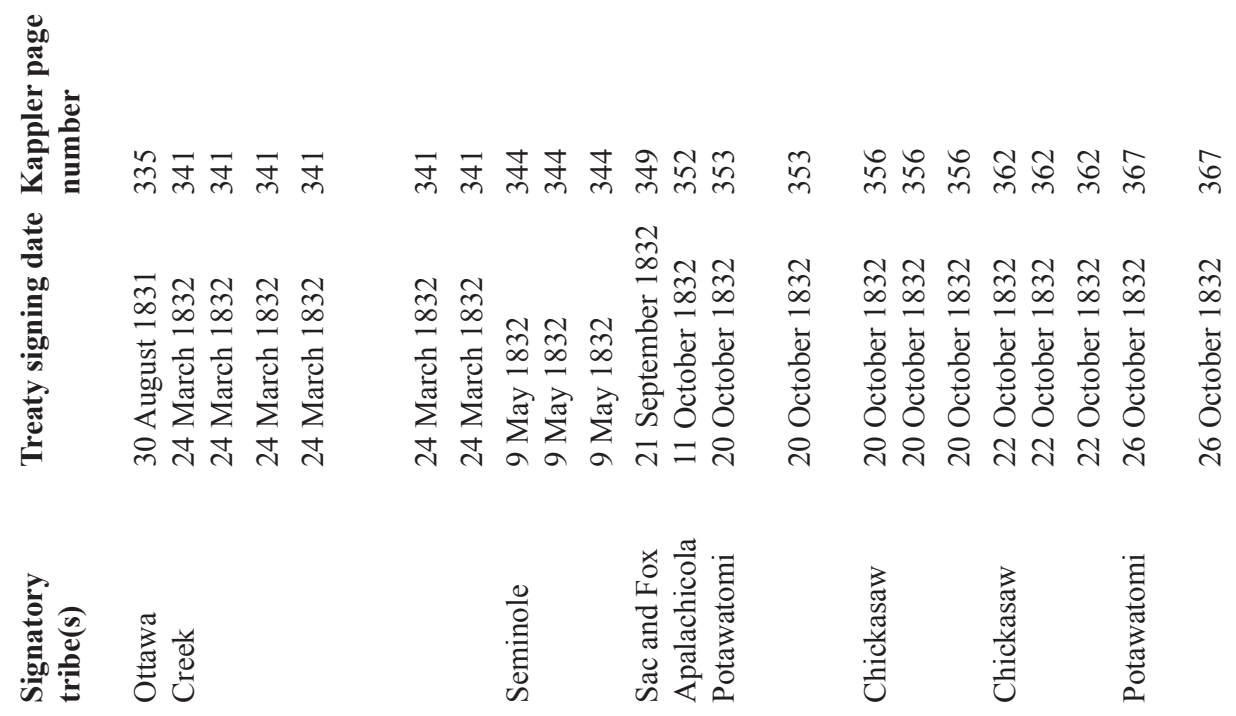

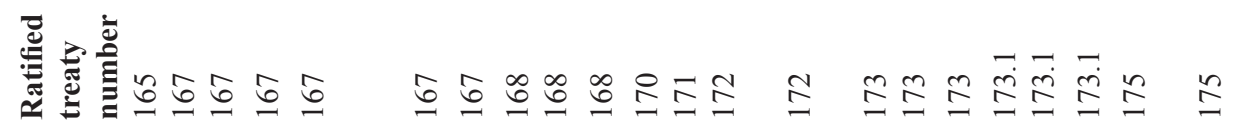




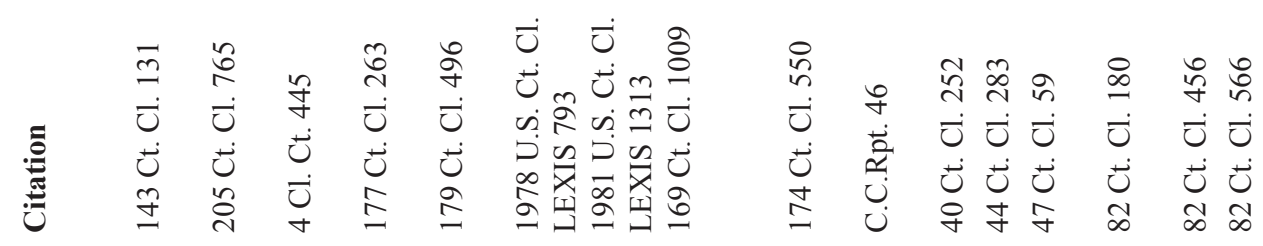

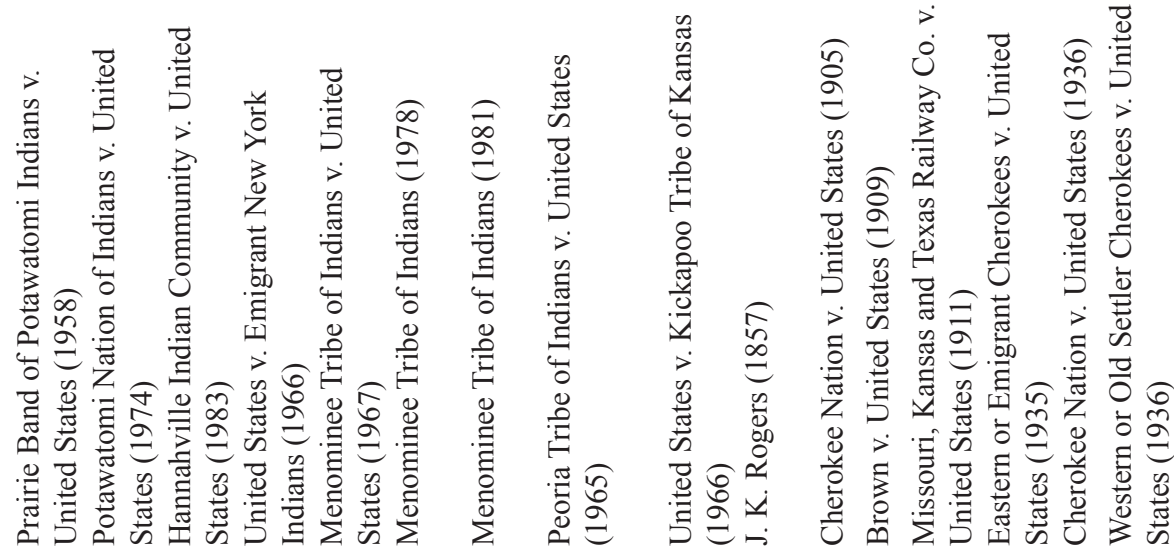

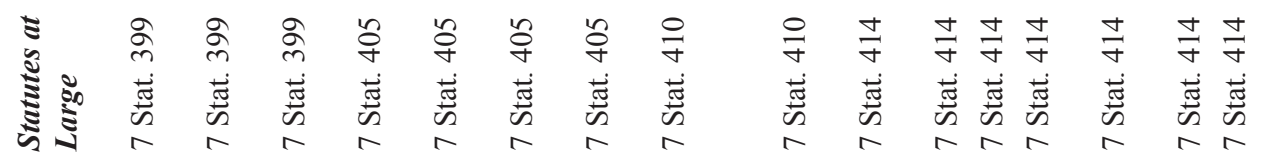
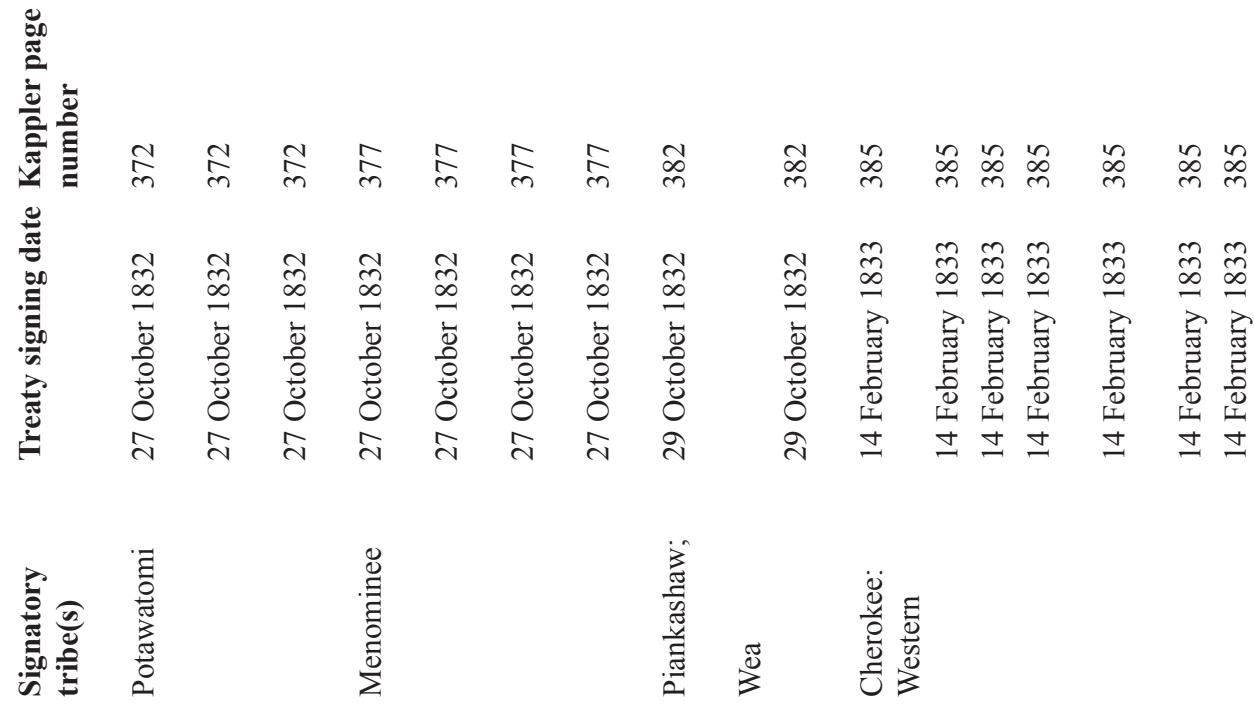

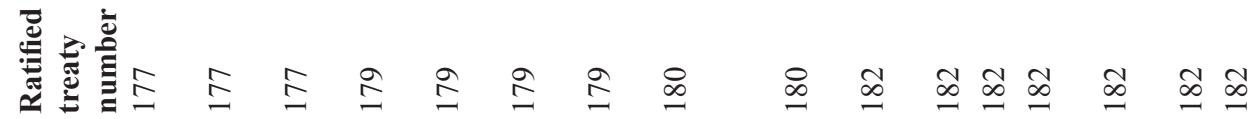




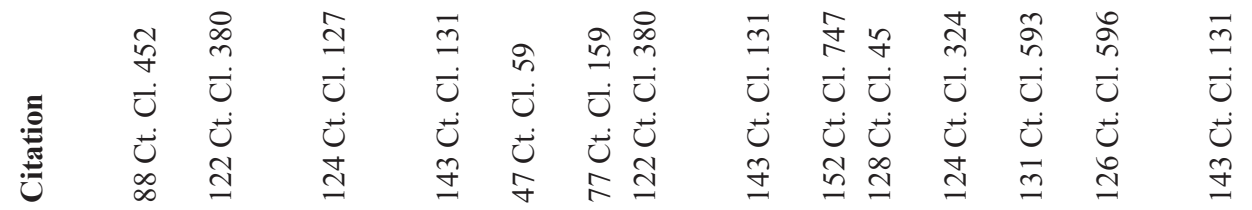

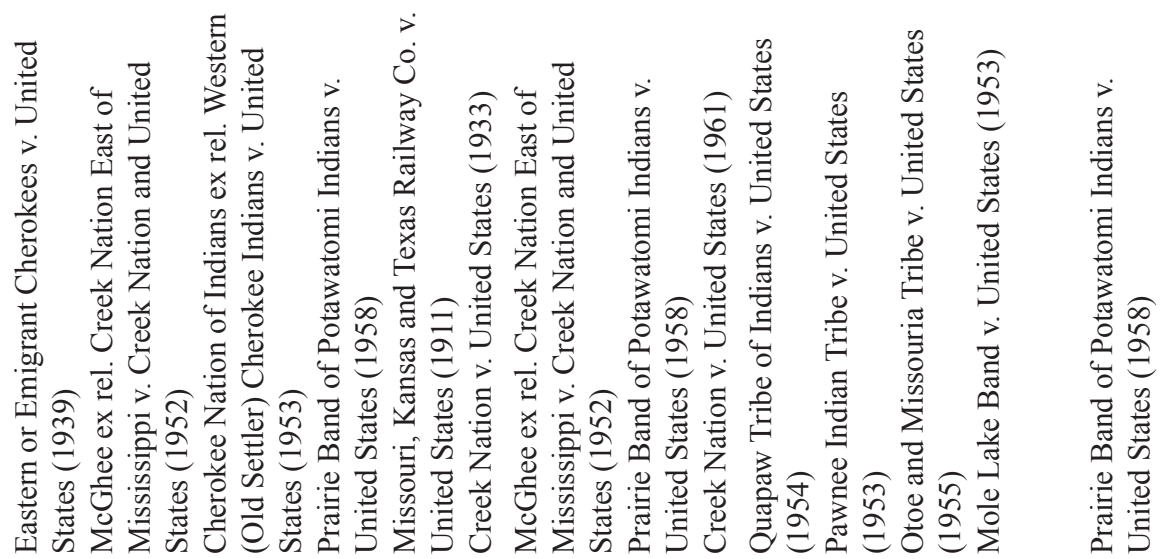

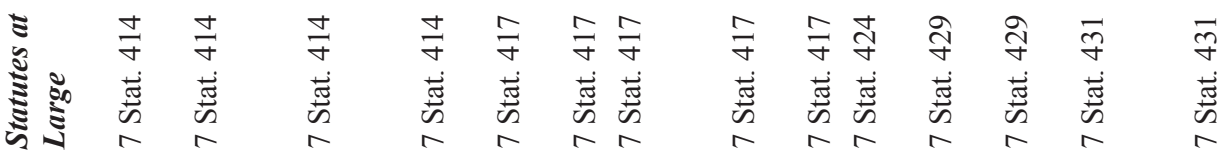

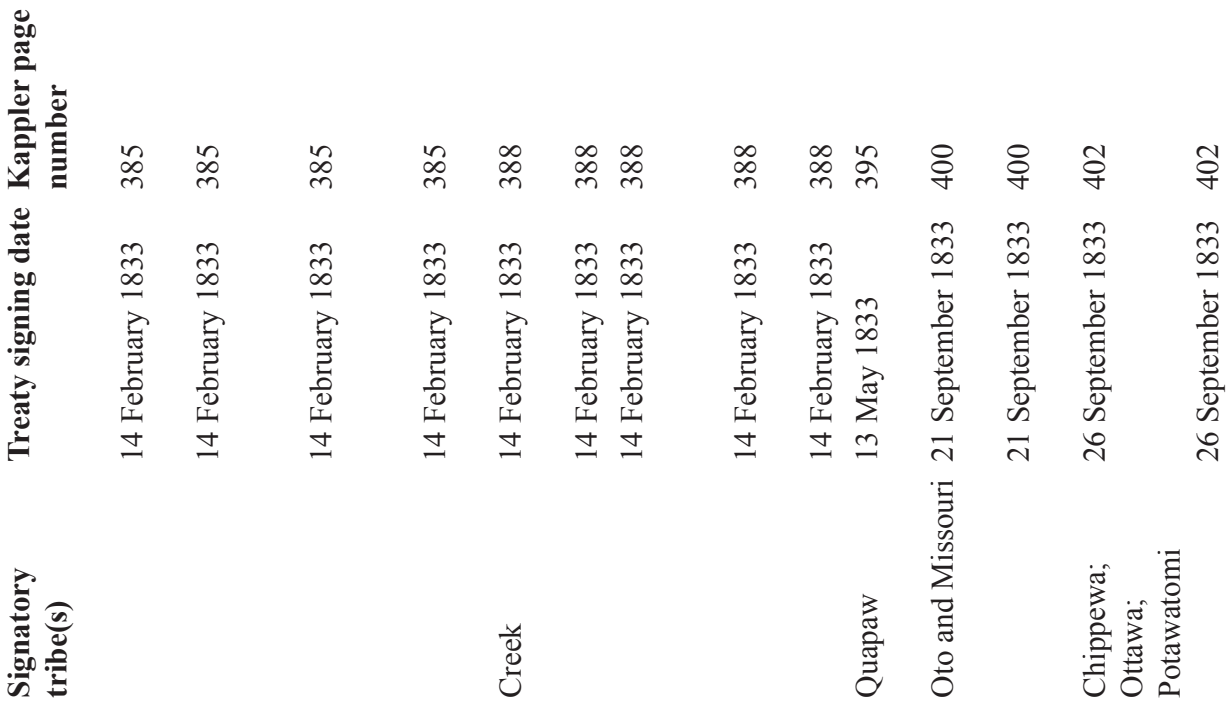

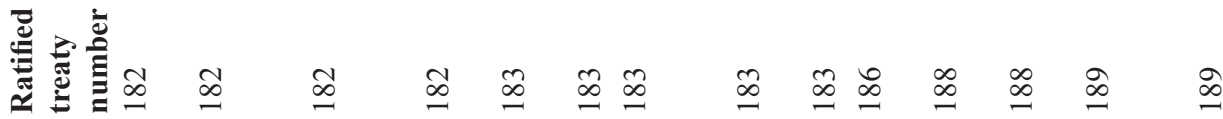




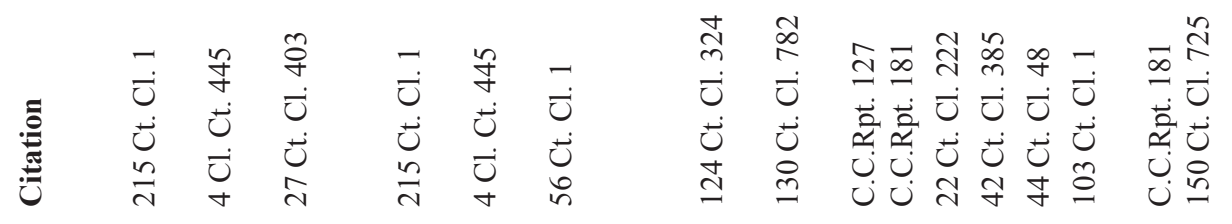

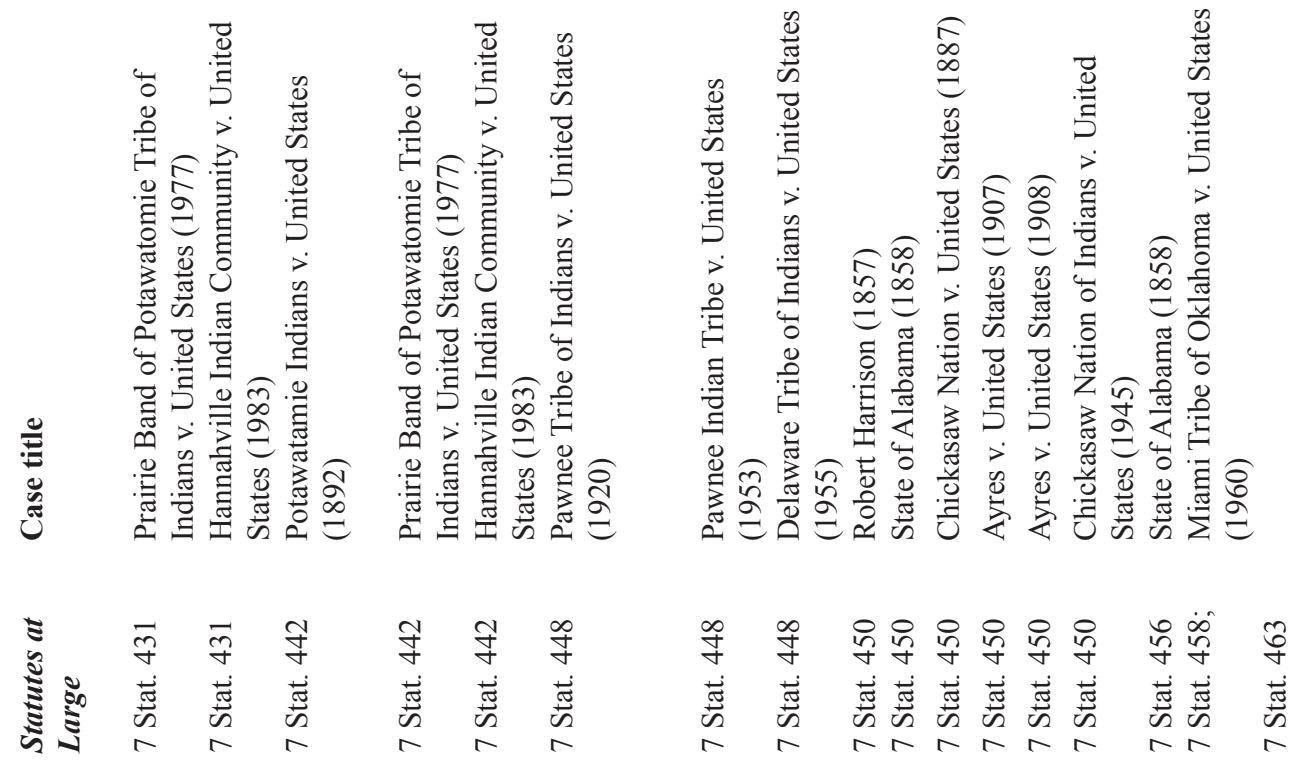
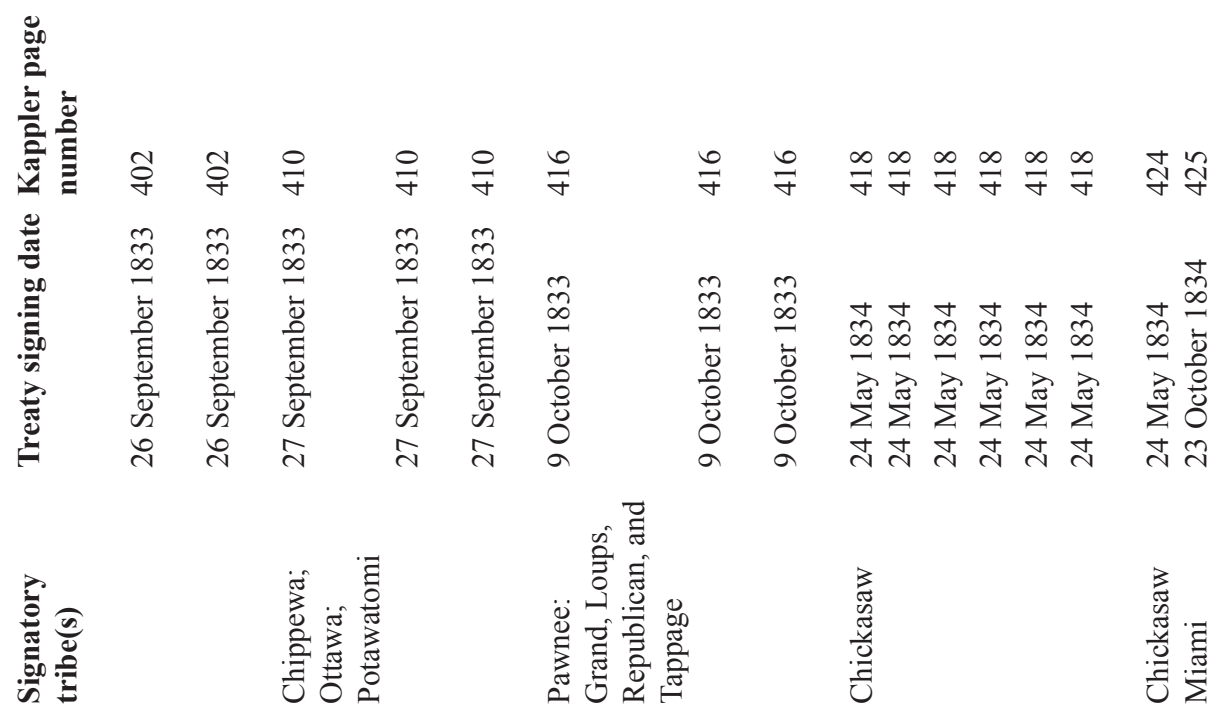

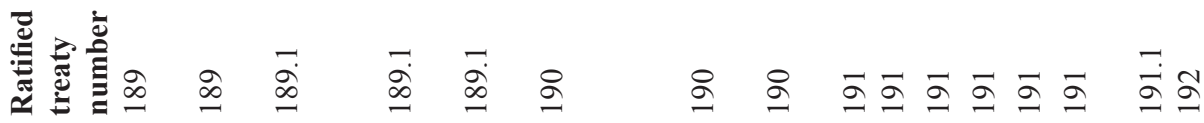




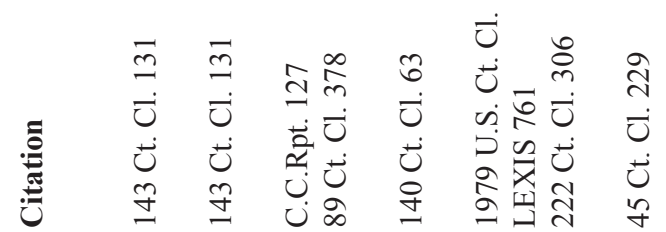

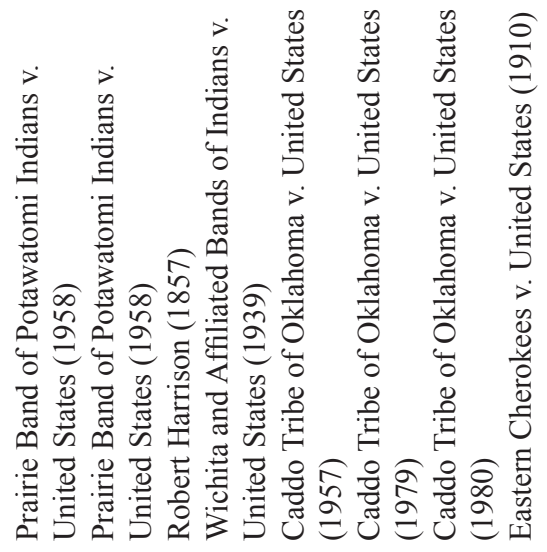

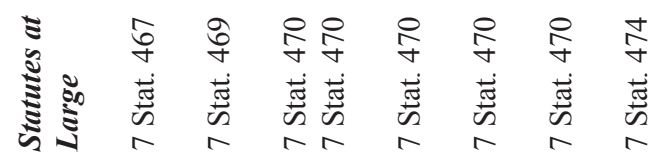
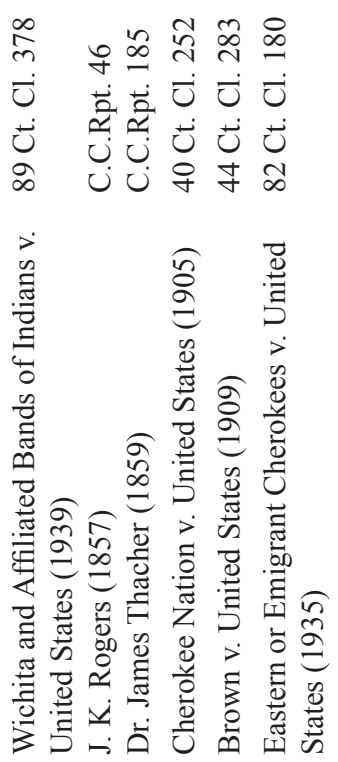

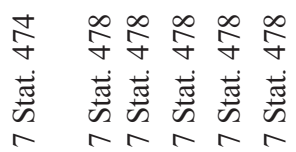

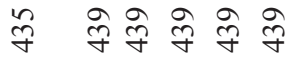

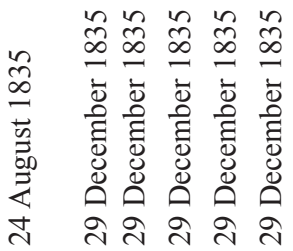

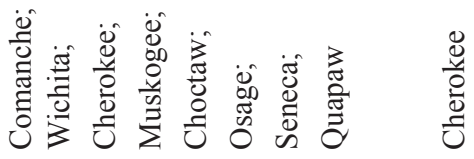




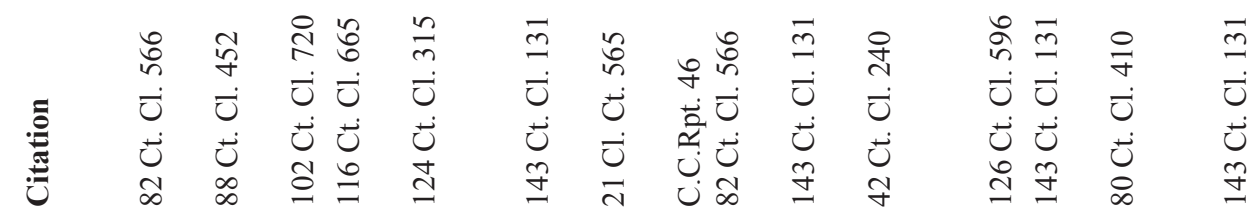

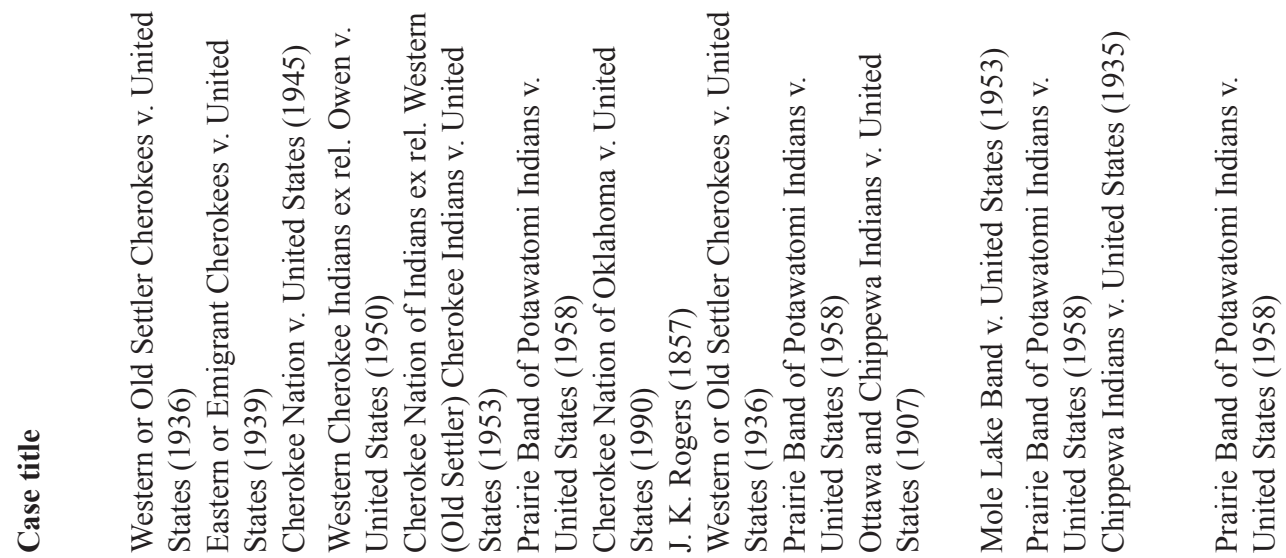

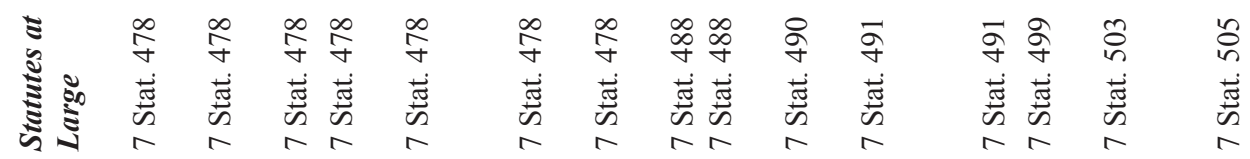

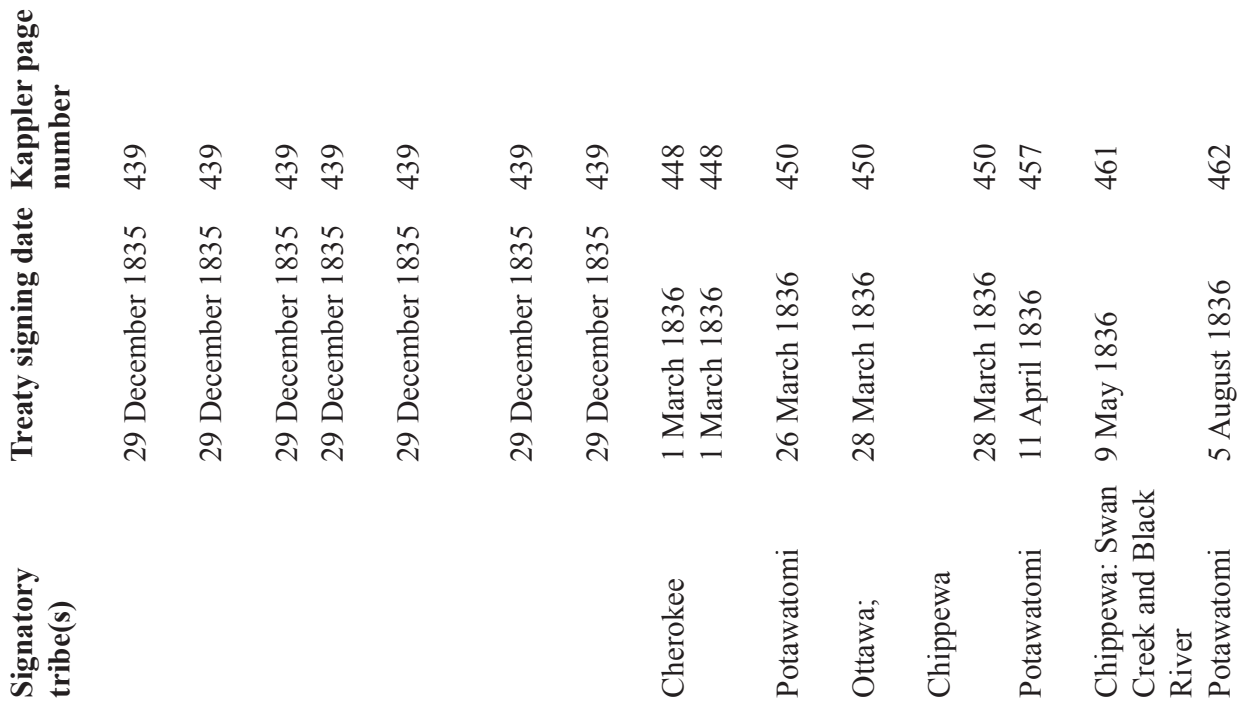

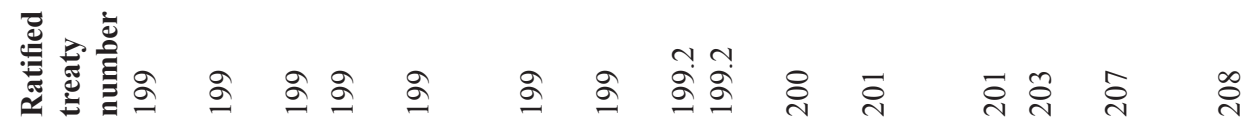




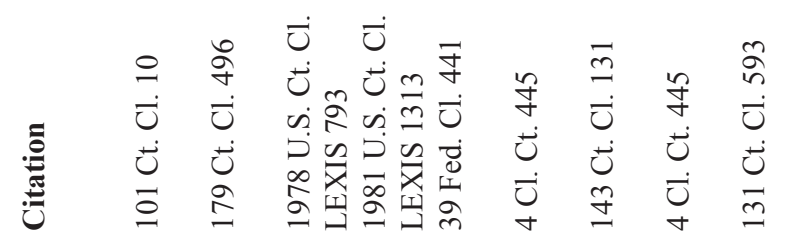

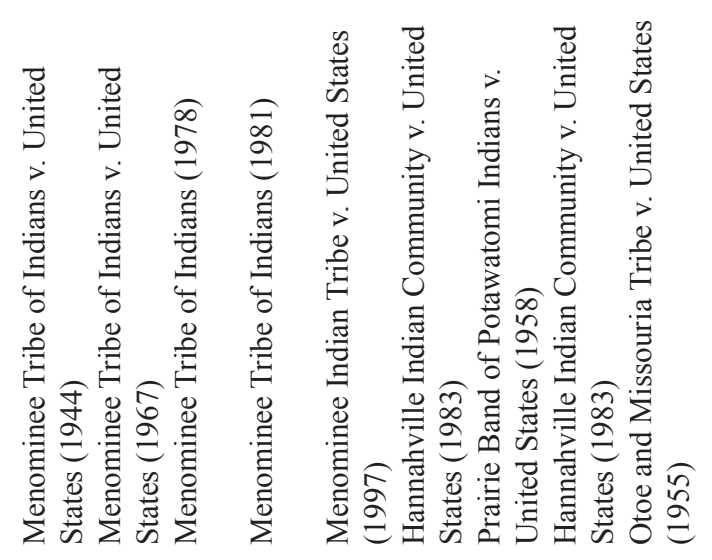

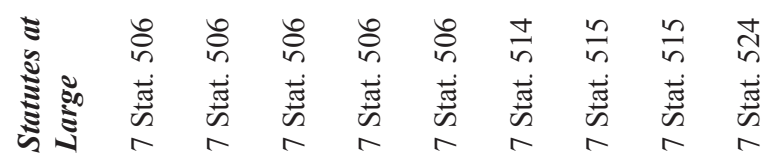

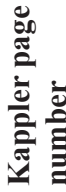

ปั.

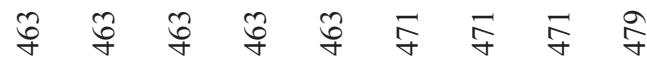

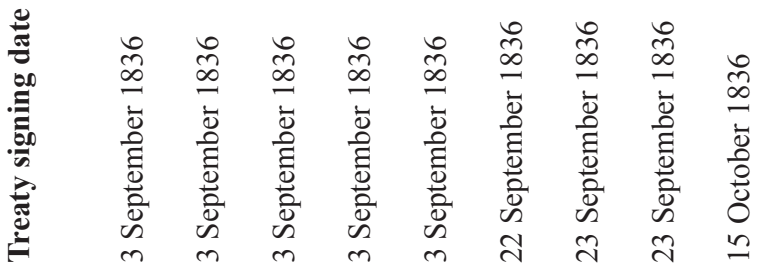
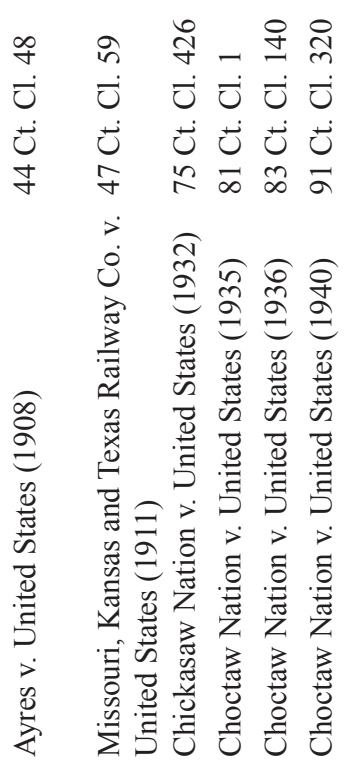

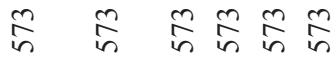

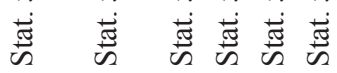

$\exists=\exists \Xi \exists=$

文

$\hat{\infty} \underset{\infty}{\infty} \hat{\infty} \infty \hat{\infty} \tilde{\infty}$

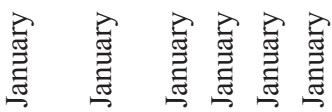

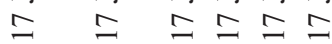

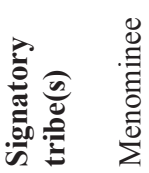

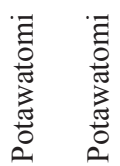

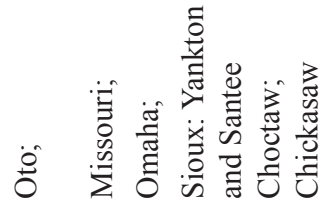




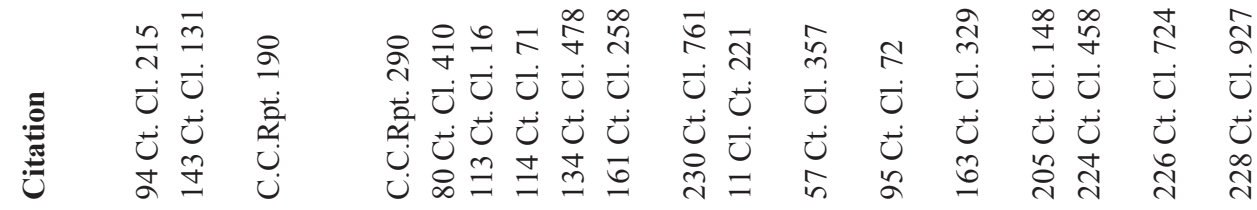

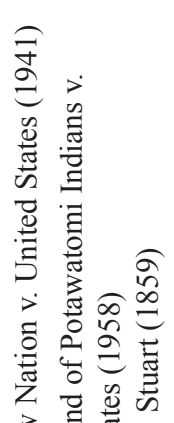

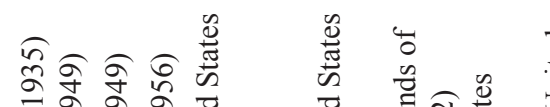

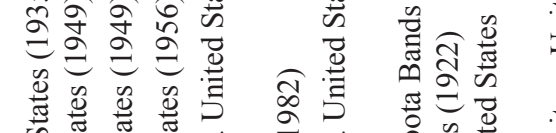

总 $\quad$ 营

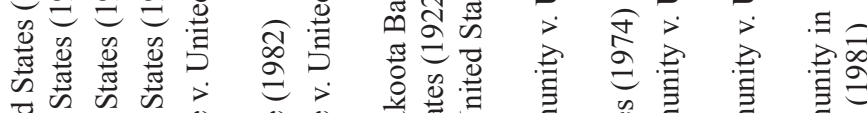

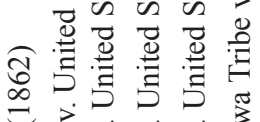
D 0

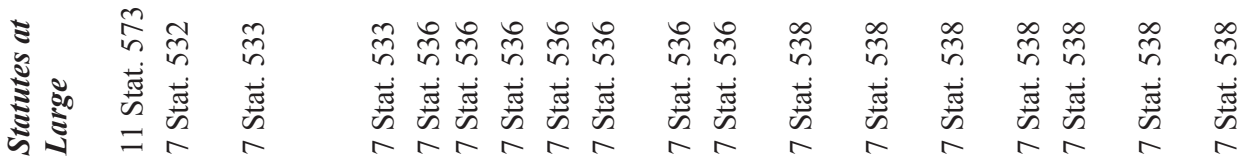

离

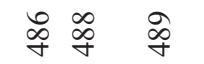

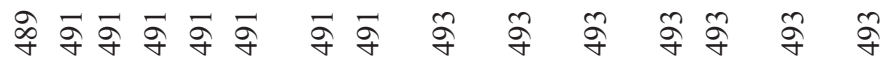

节

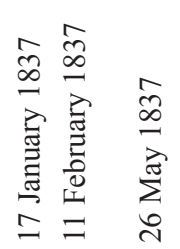

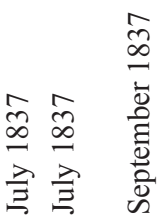

$\hat{\infty} \hat{\infty} \hat{\infty} \hat{\infty} \hat{\infty} \hat{\infty} \hat{\infty}$

量

$\hat{\infty} \hat{\infty} \tilde{\infty} \hat{\infty} \hat{\infty} \hat{\infty} \hat{\infty}$

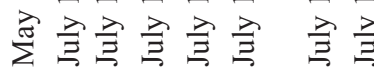

ते ते ते वे वे

ते ते

ลे จ
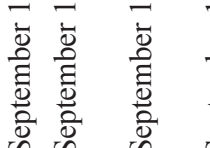

跣

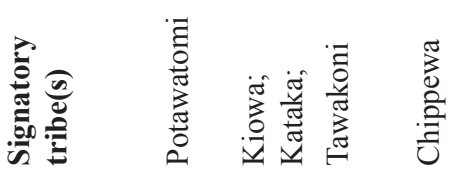

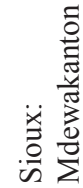

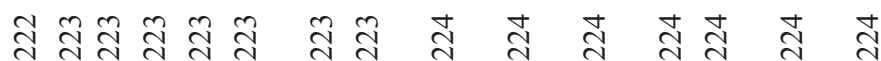



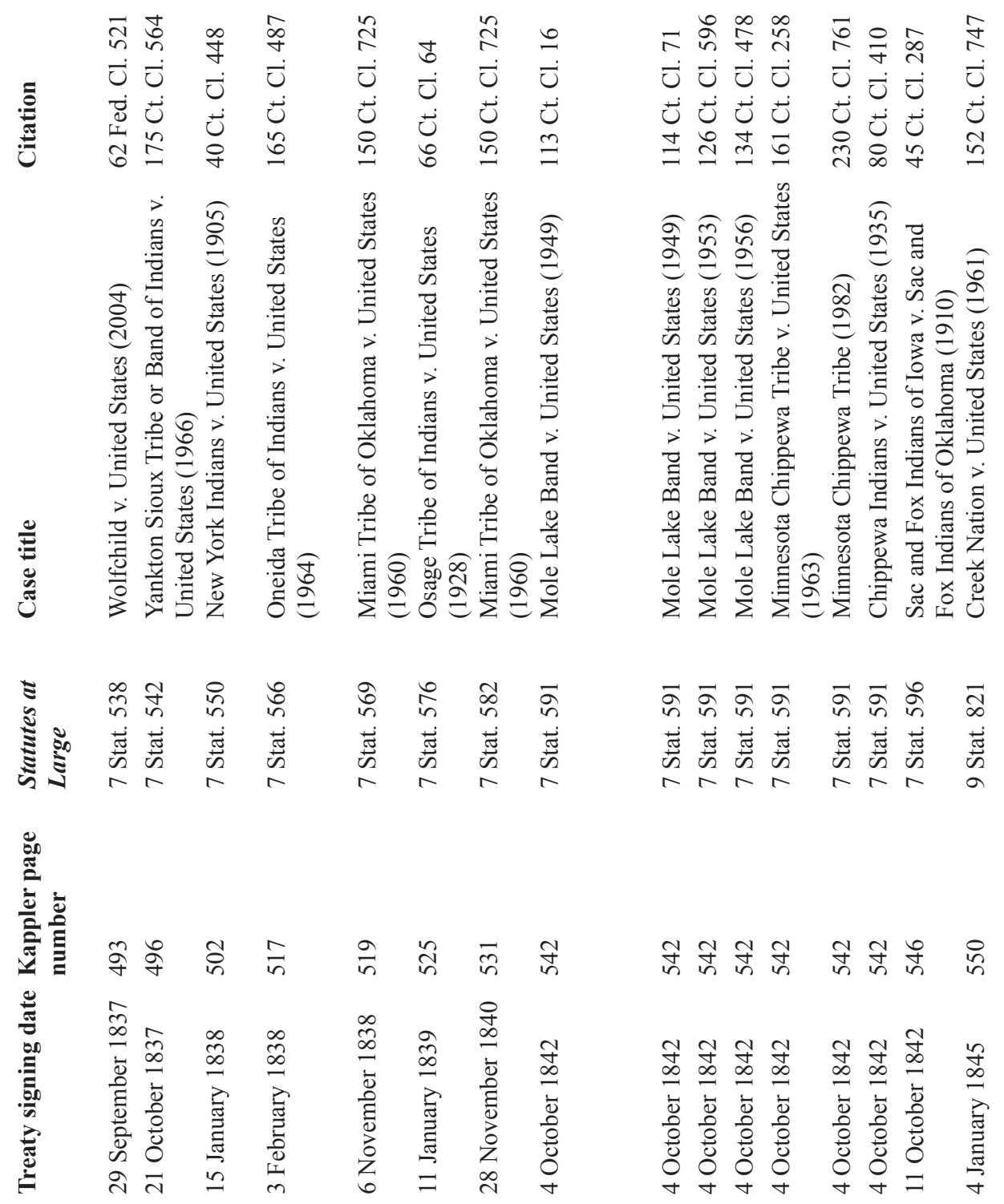

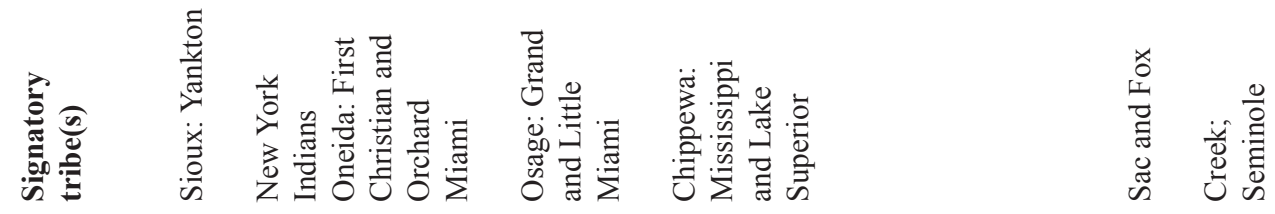

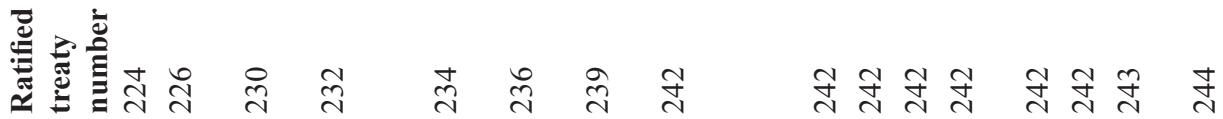




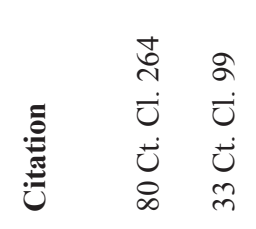

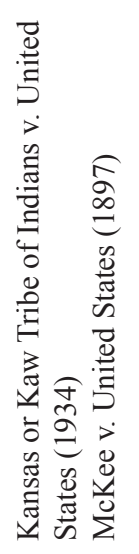

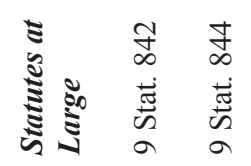
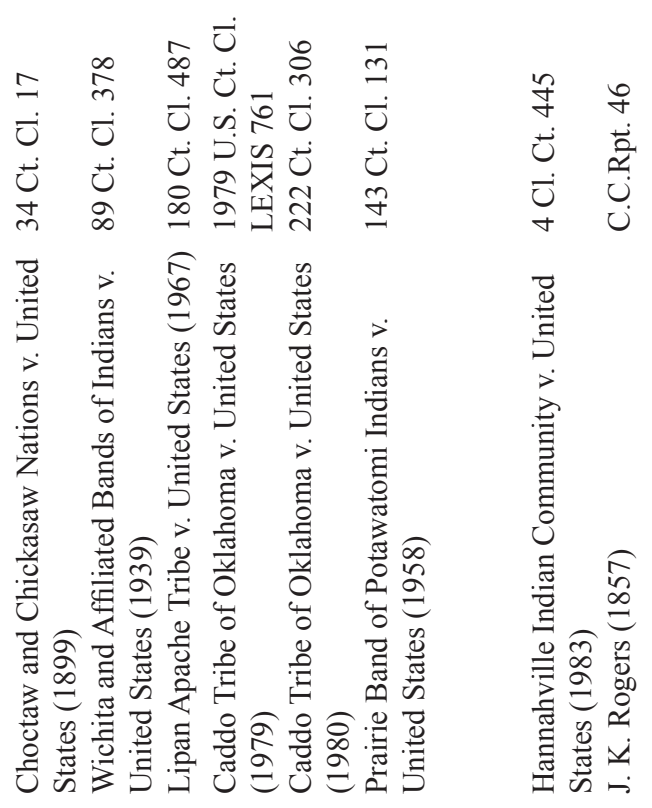

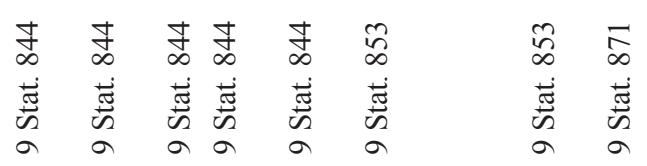

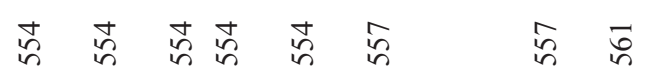

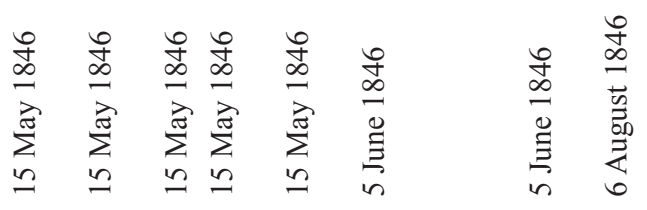

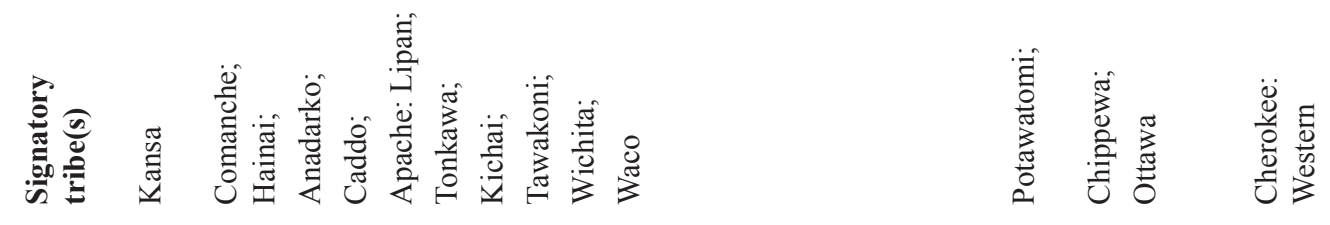

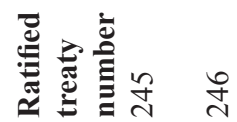

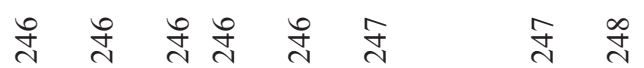




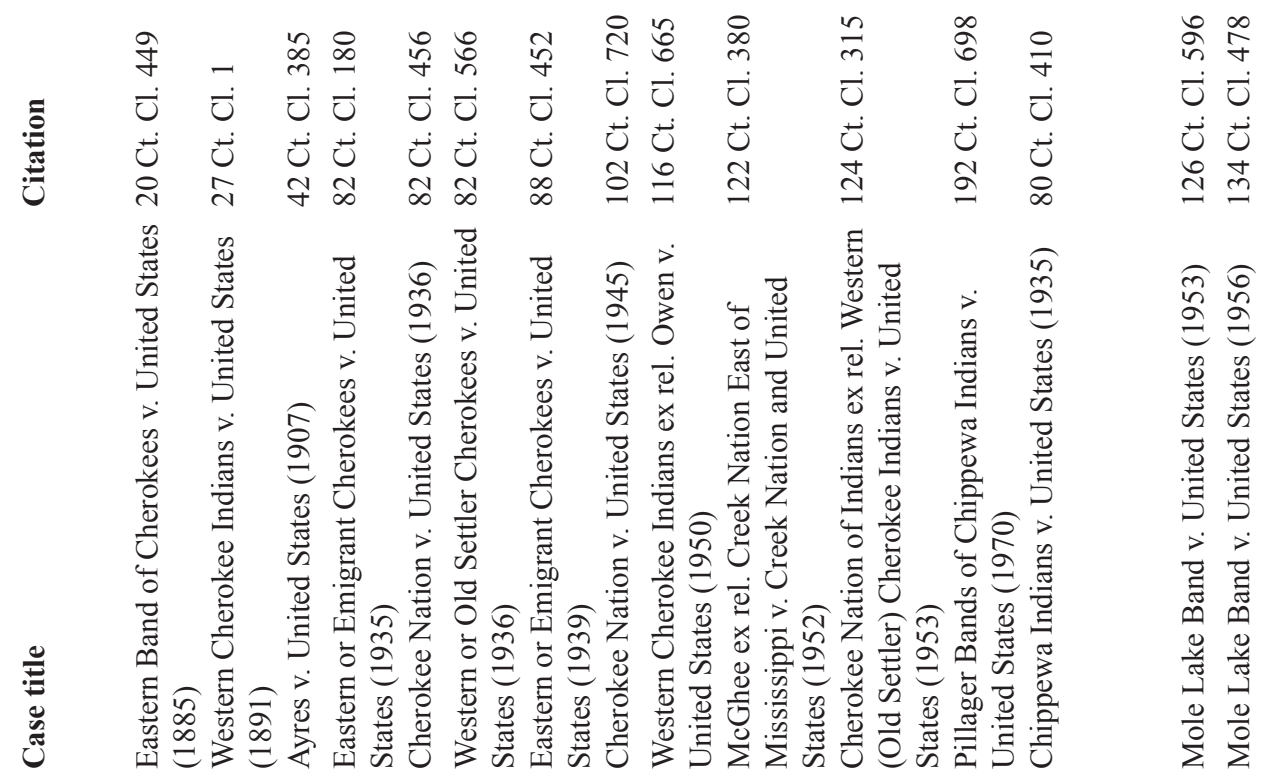

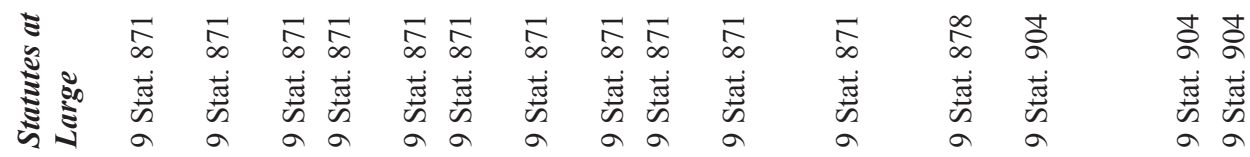

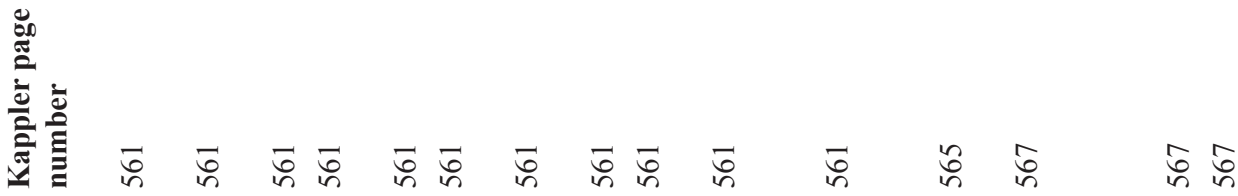

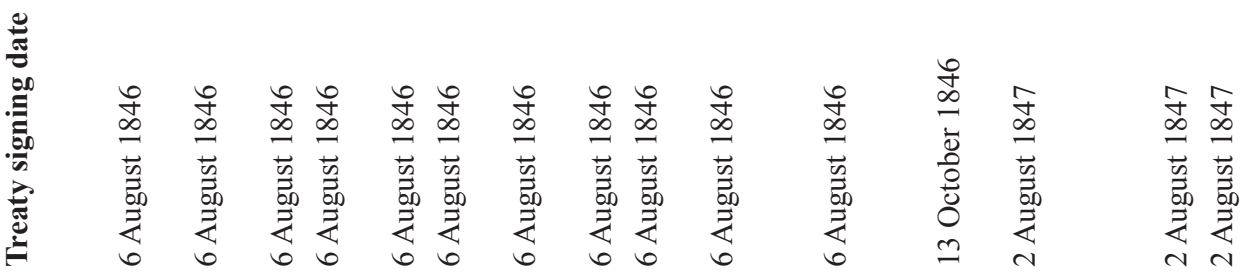
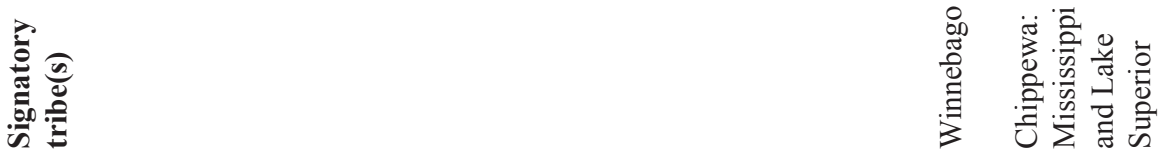

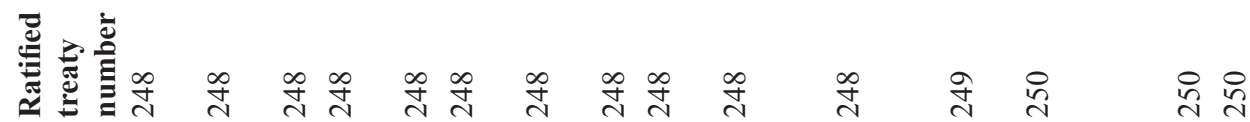



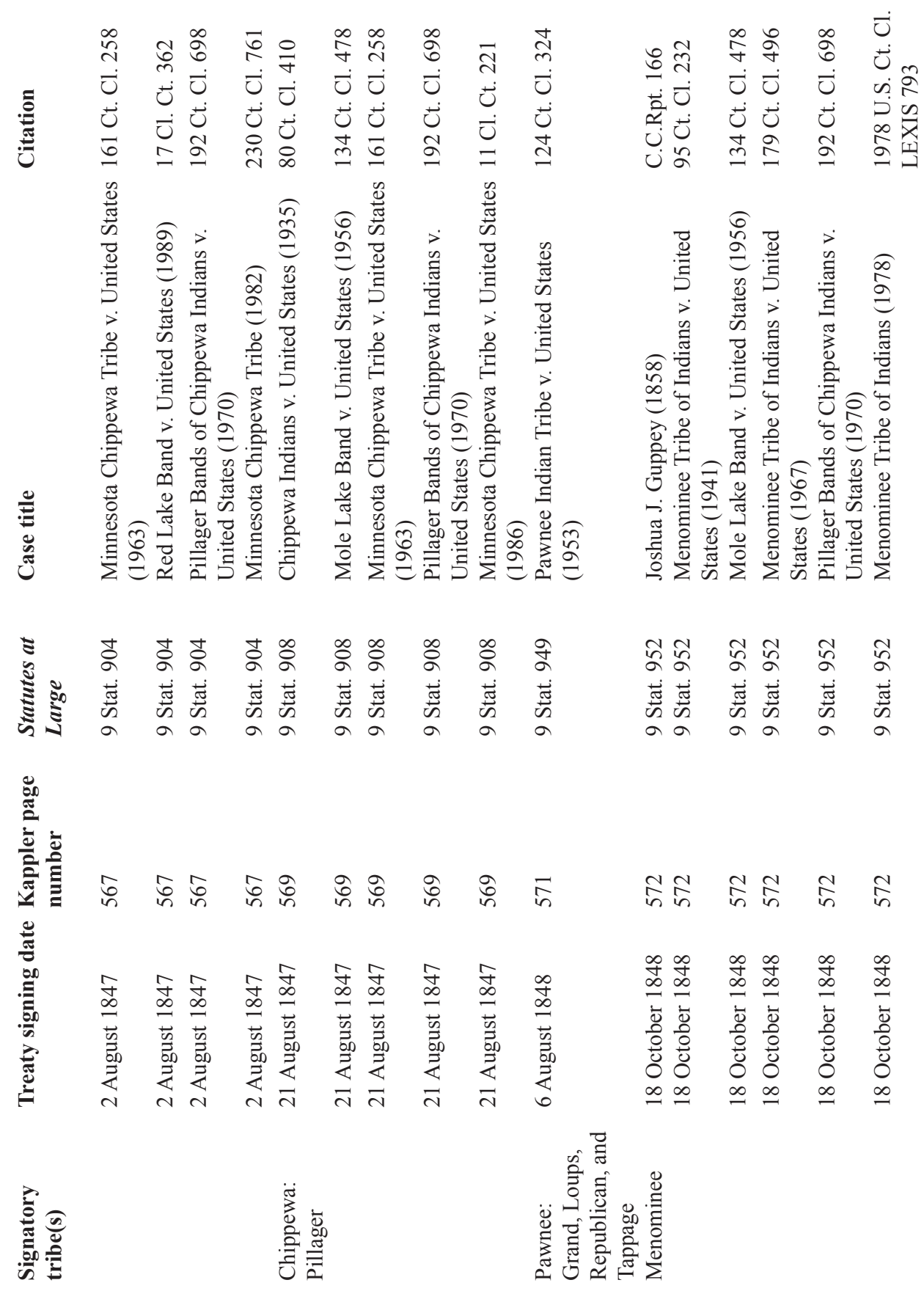

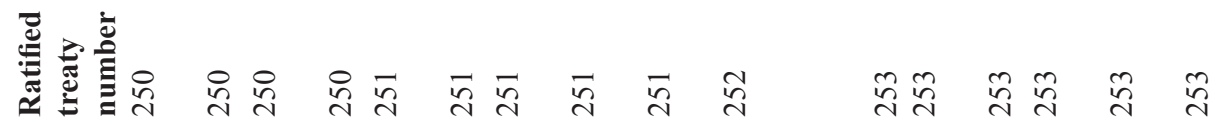




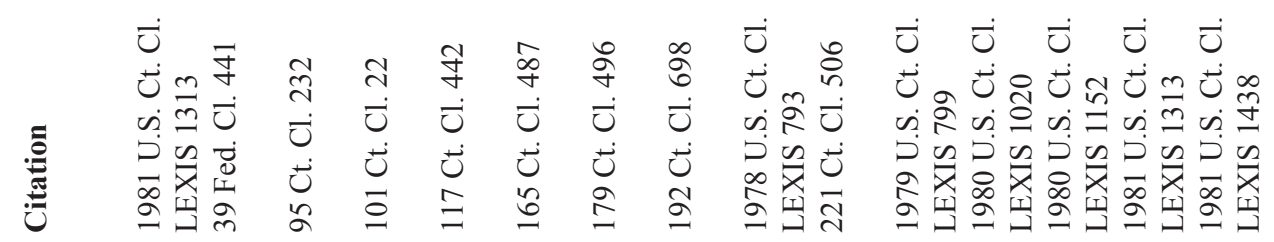

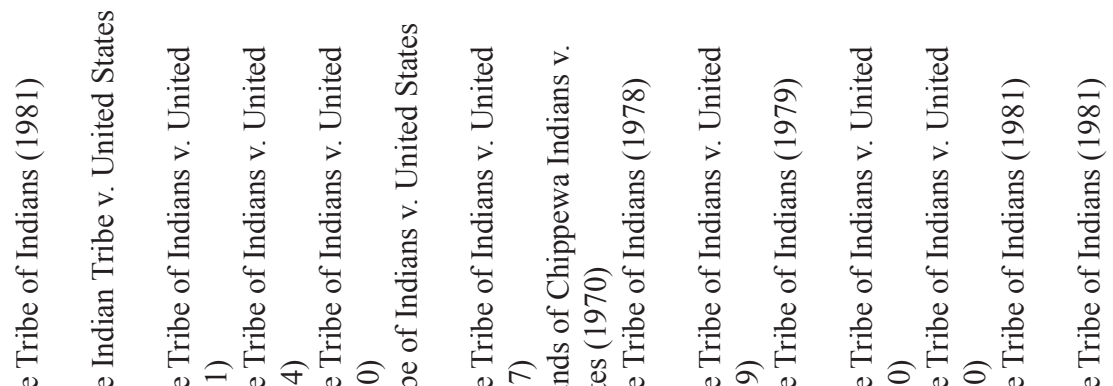

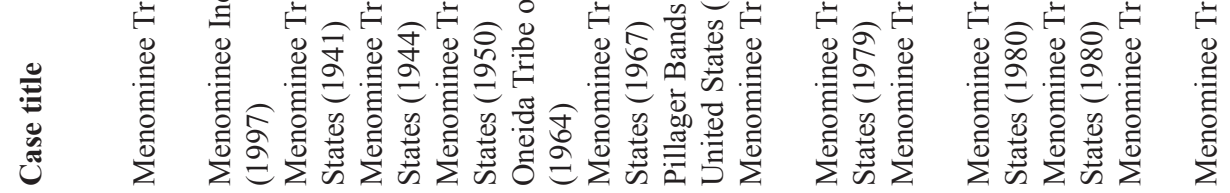

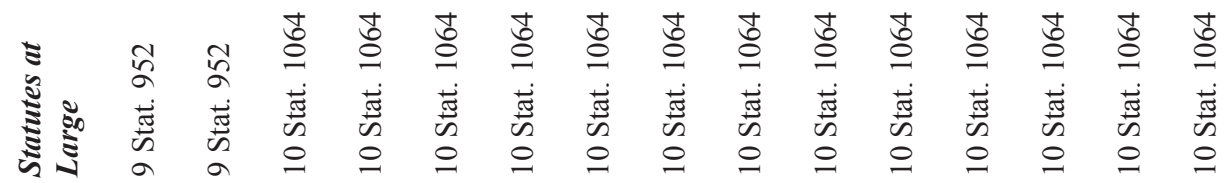

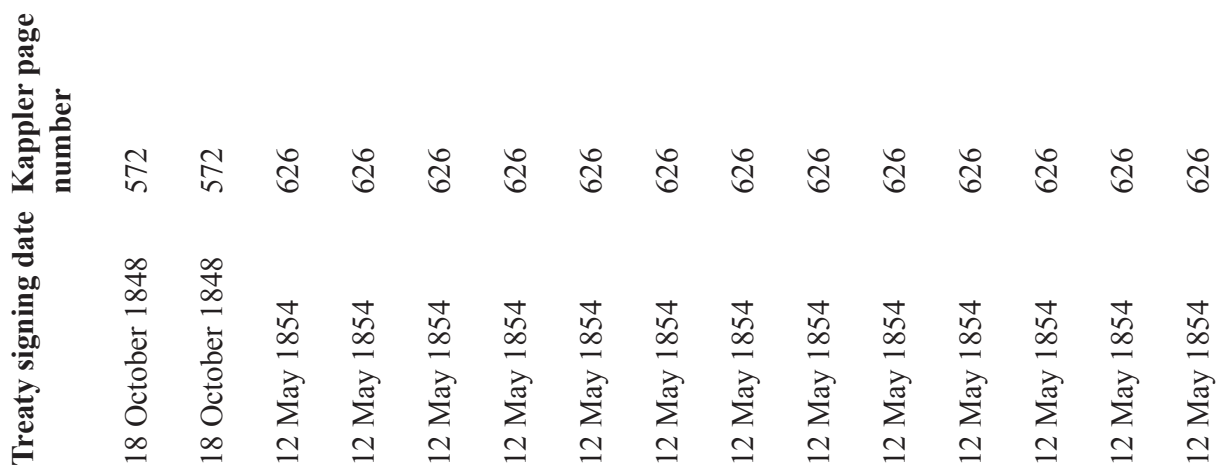

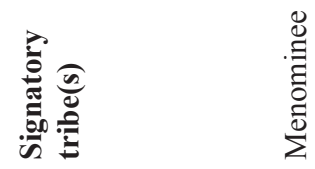

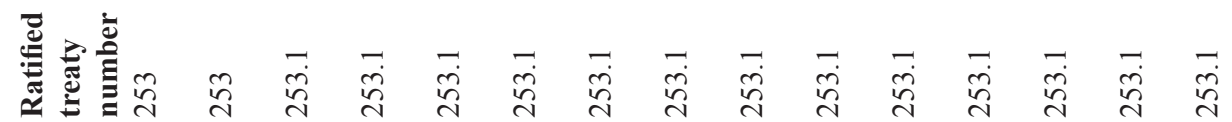




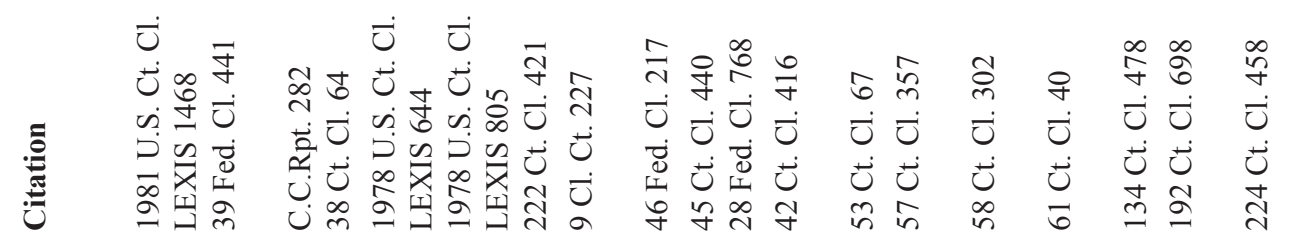

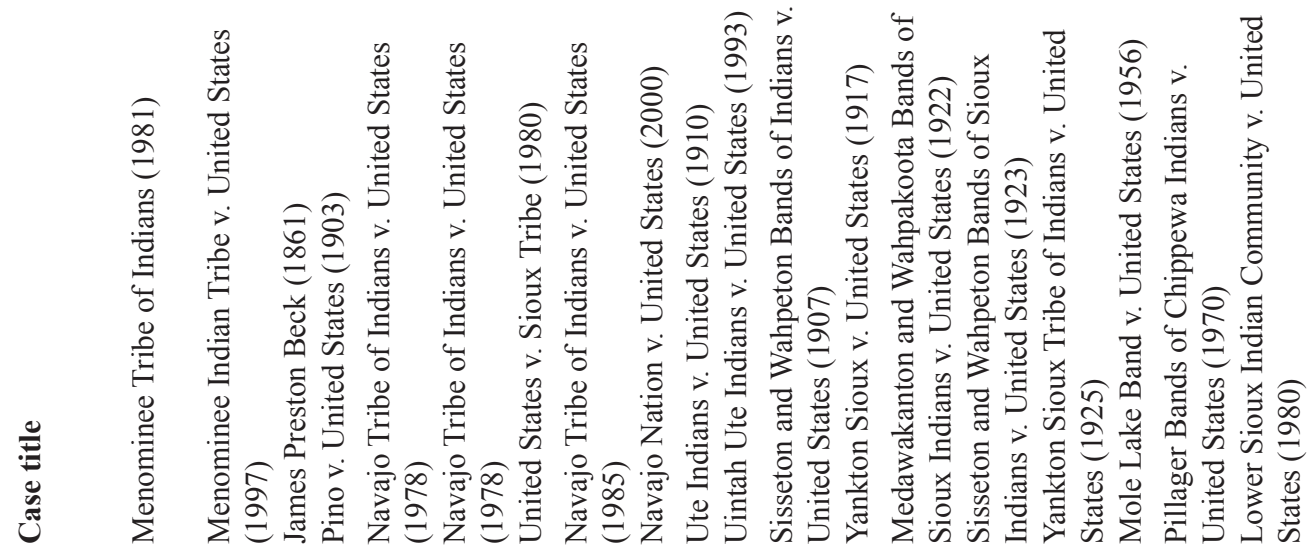

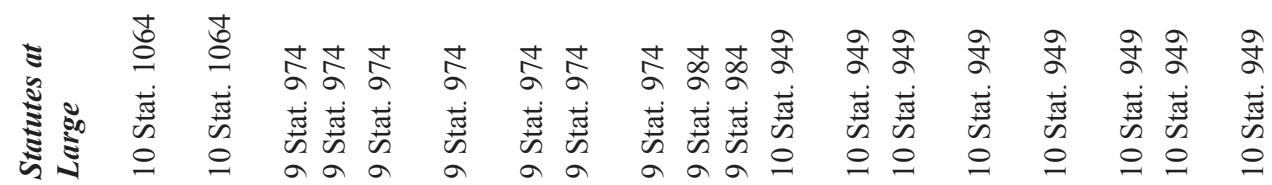

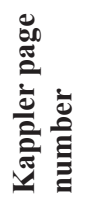

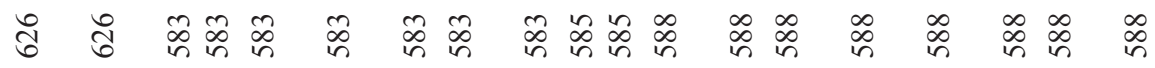

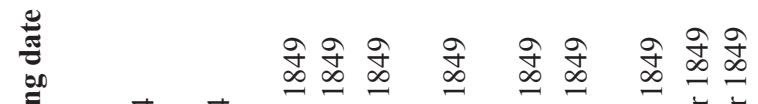

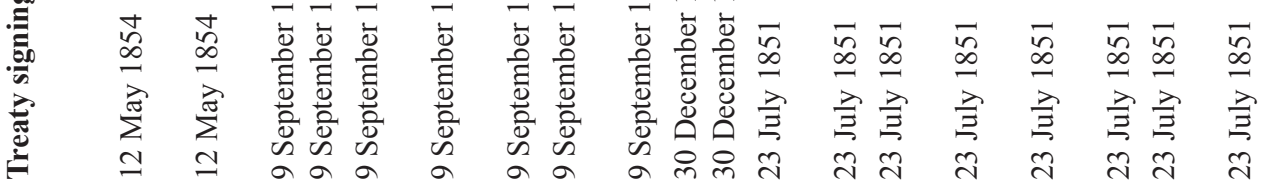

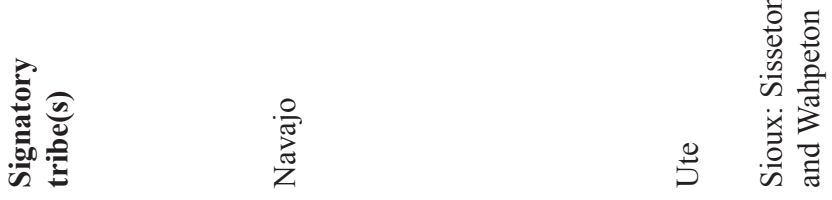

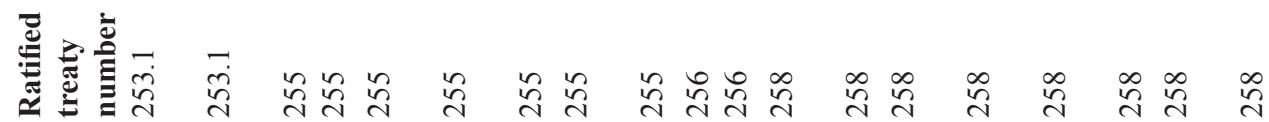




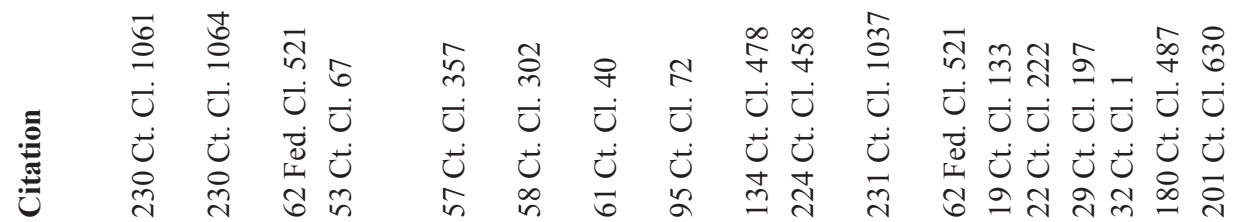

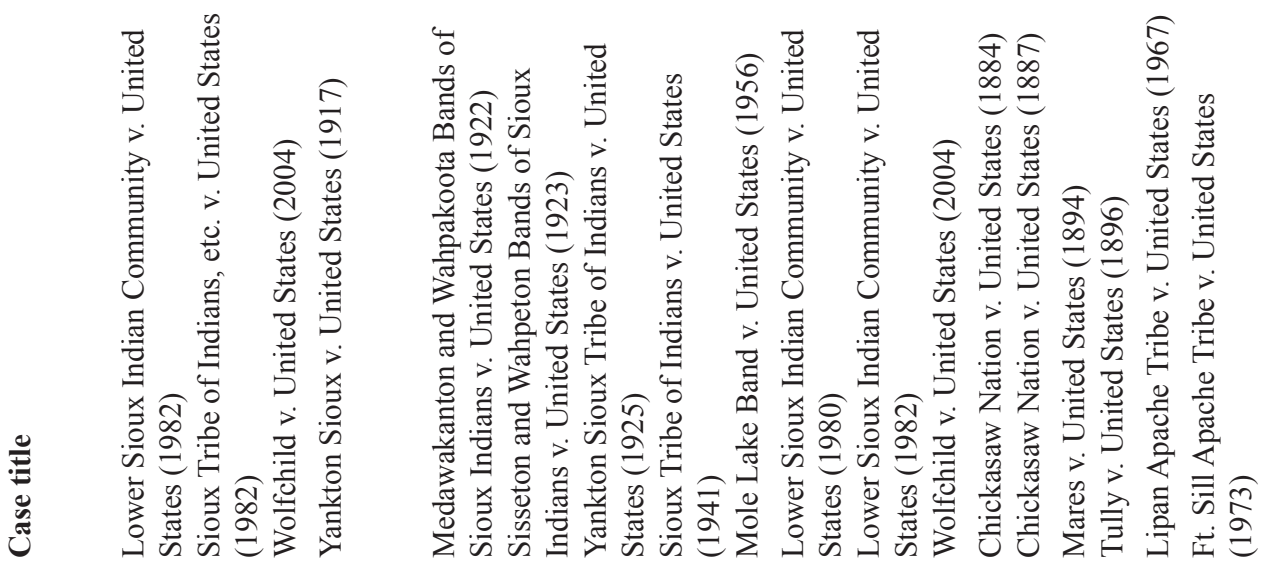

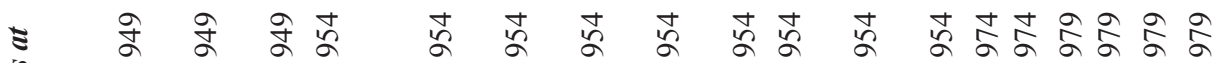

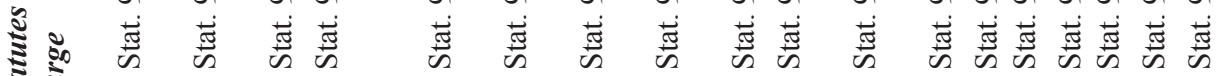

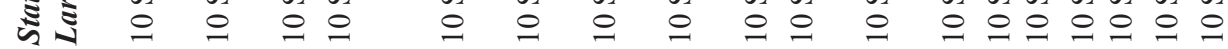

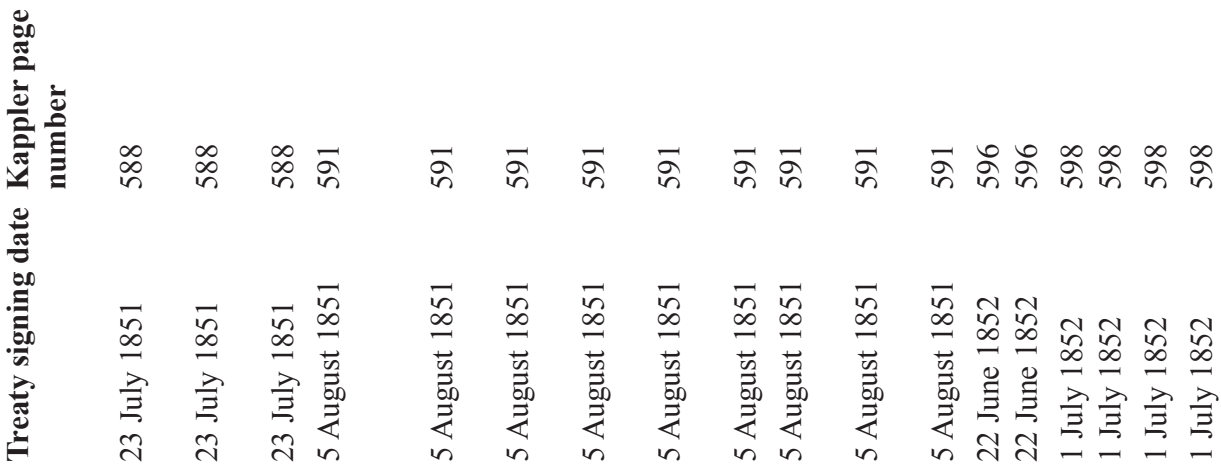
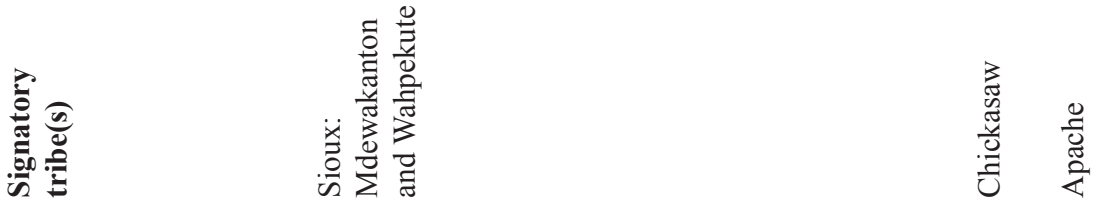

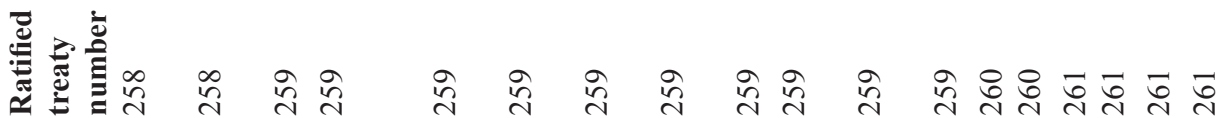




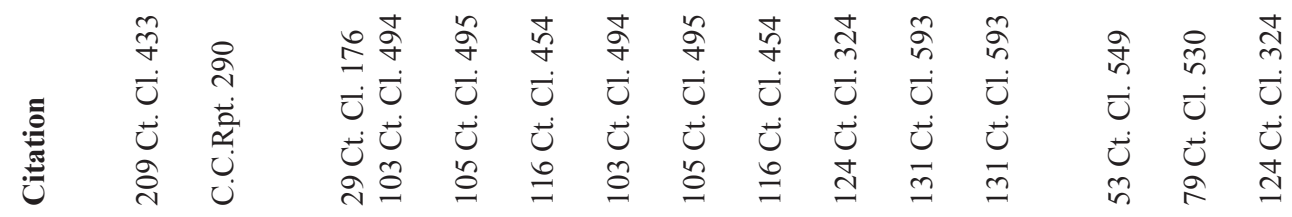

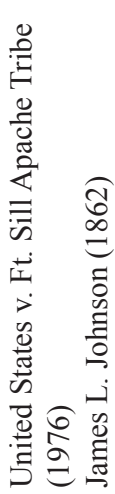

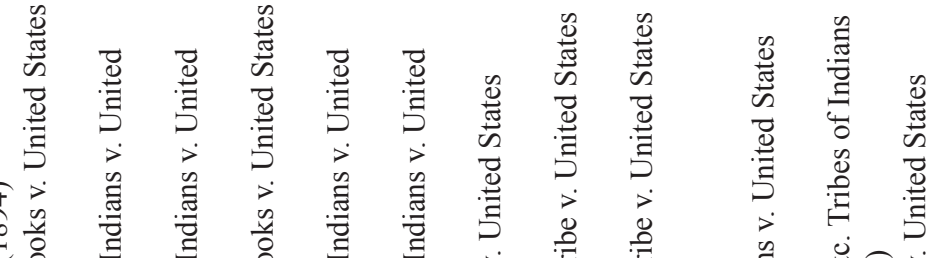

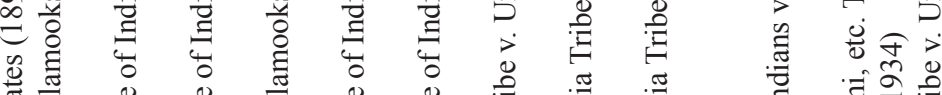

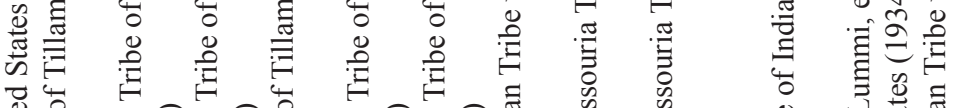

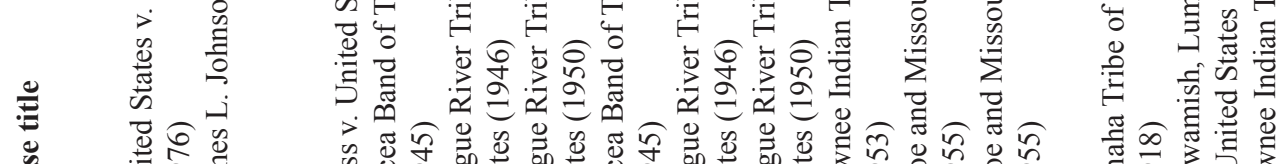

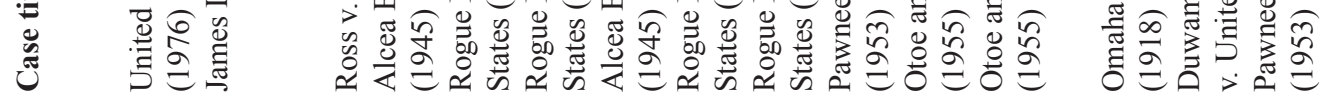

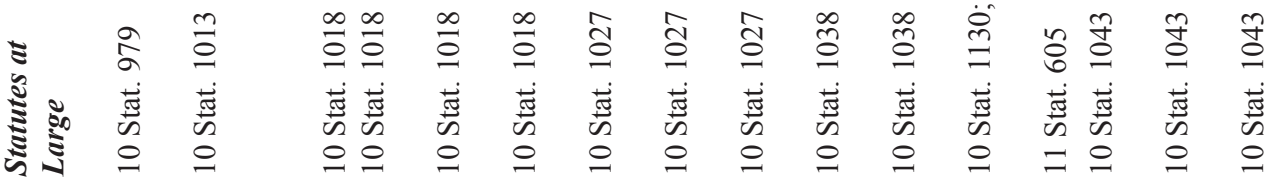

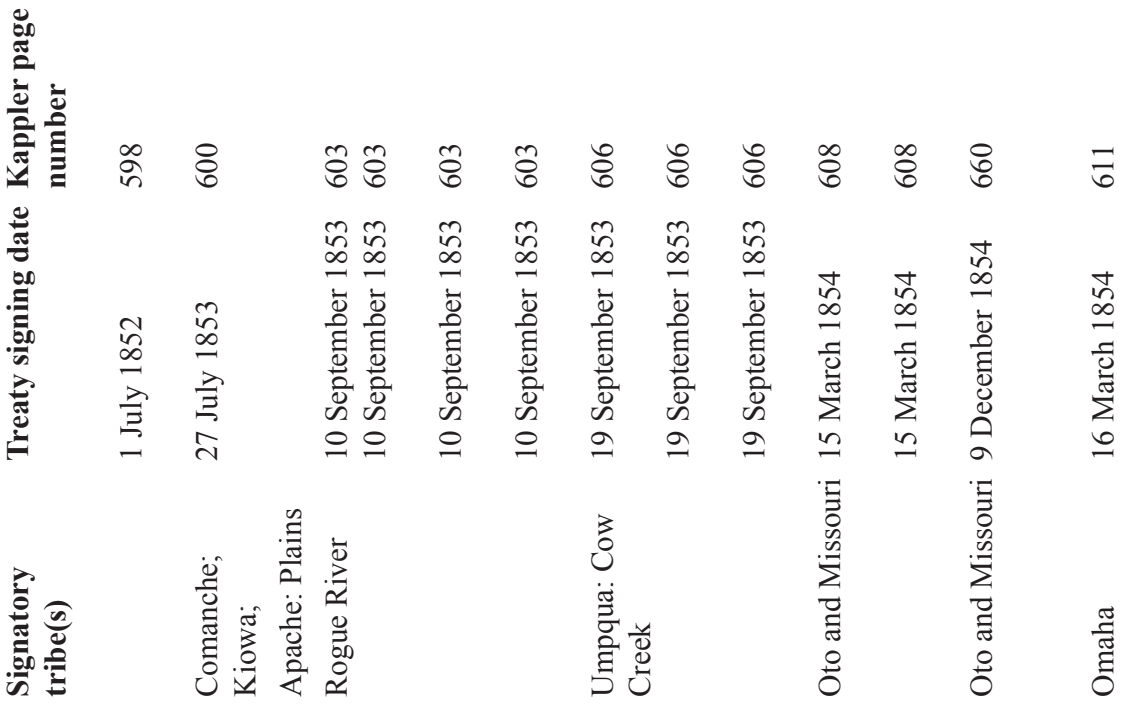

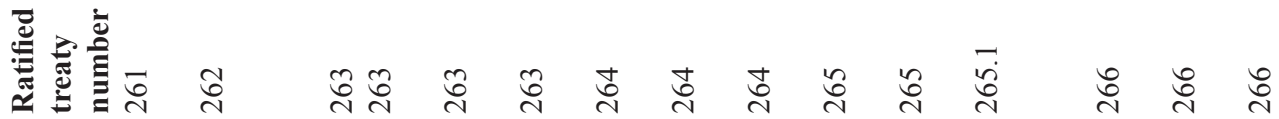




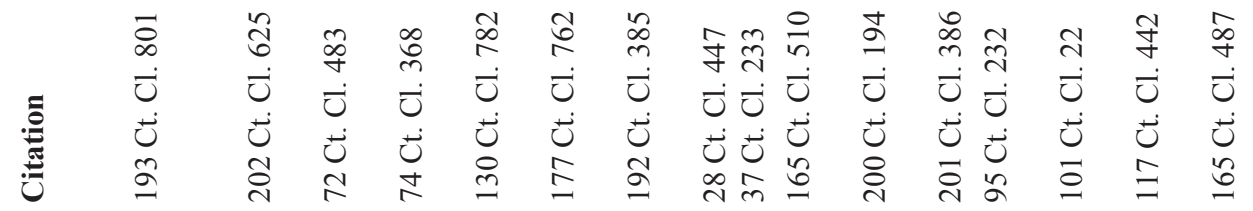

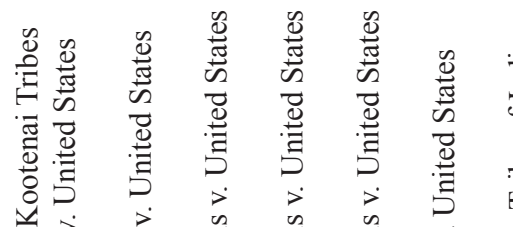

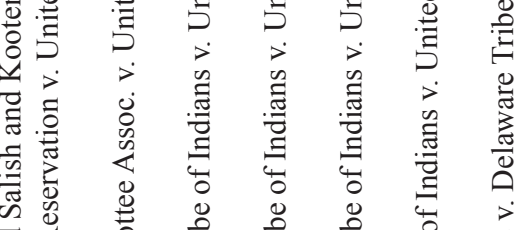

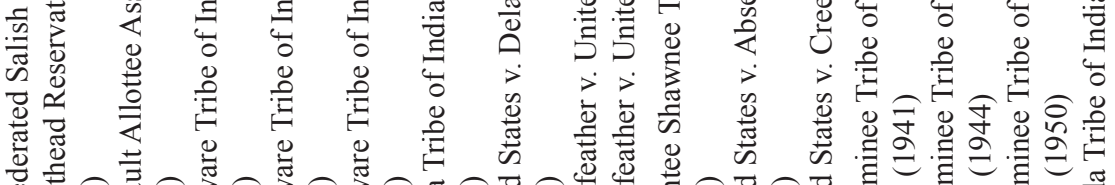

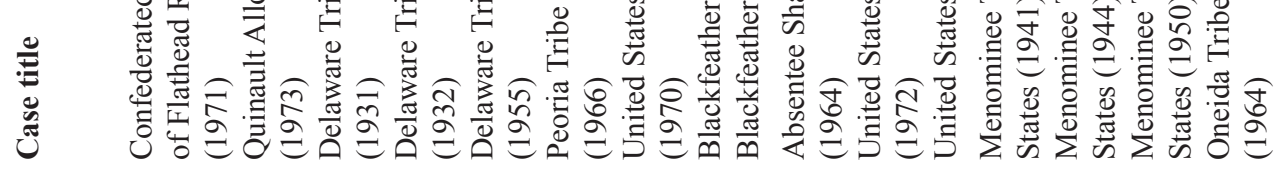

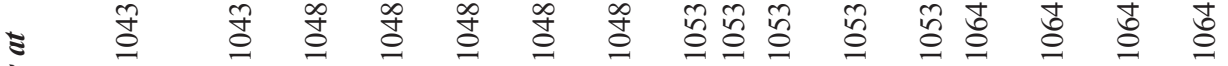

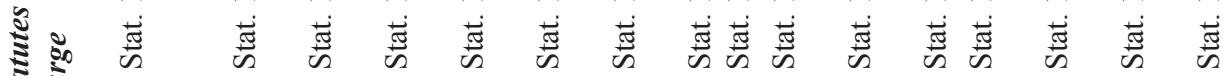

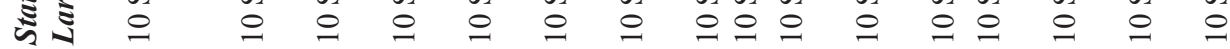

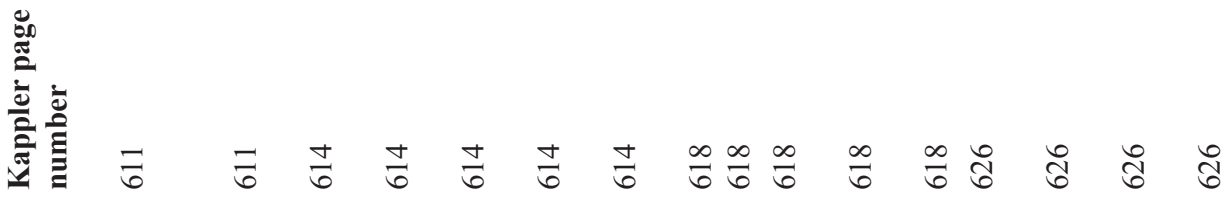

节

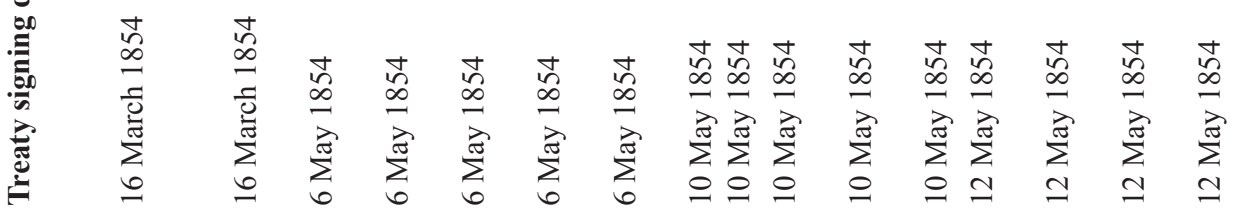

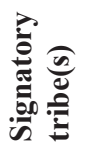

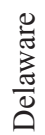

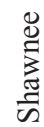

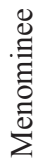

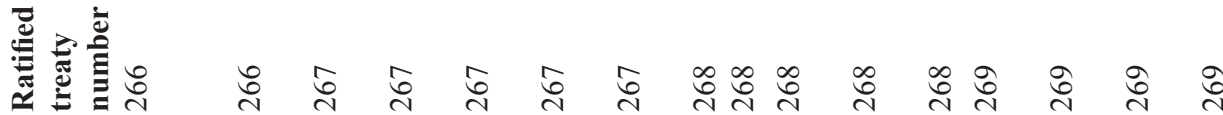




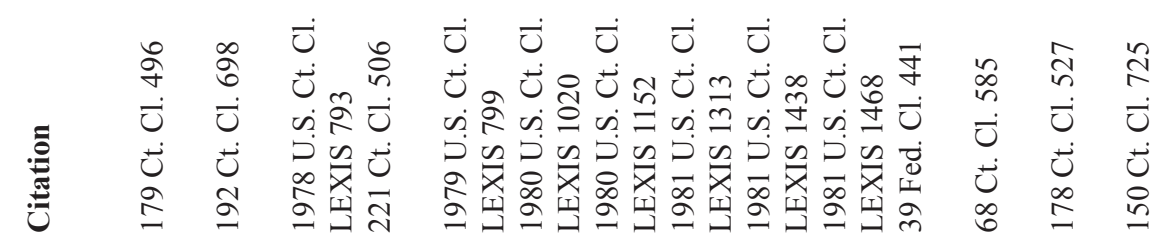

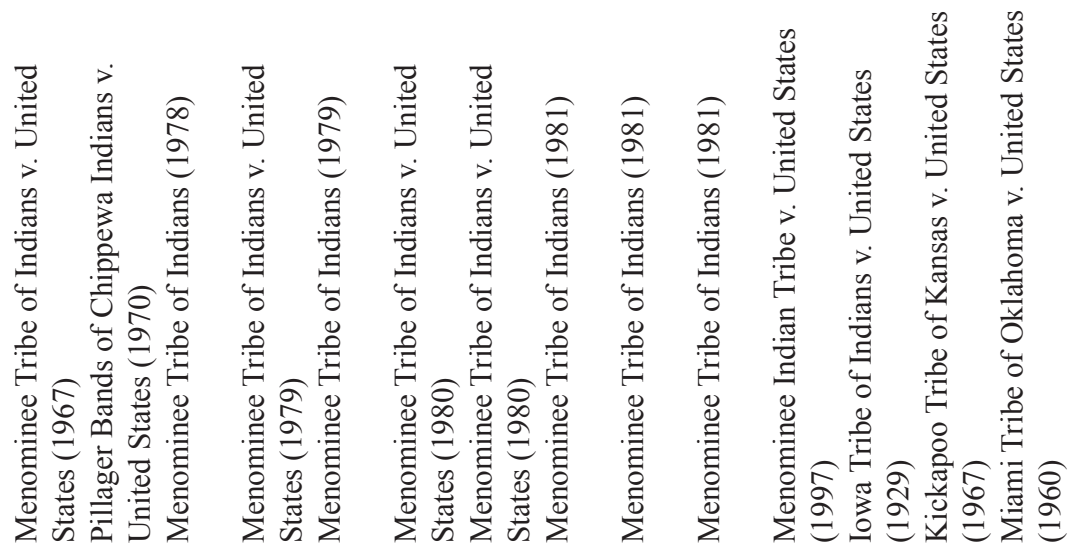

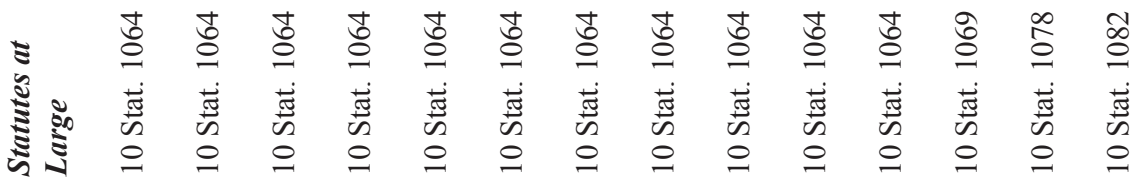
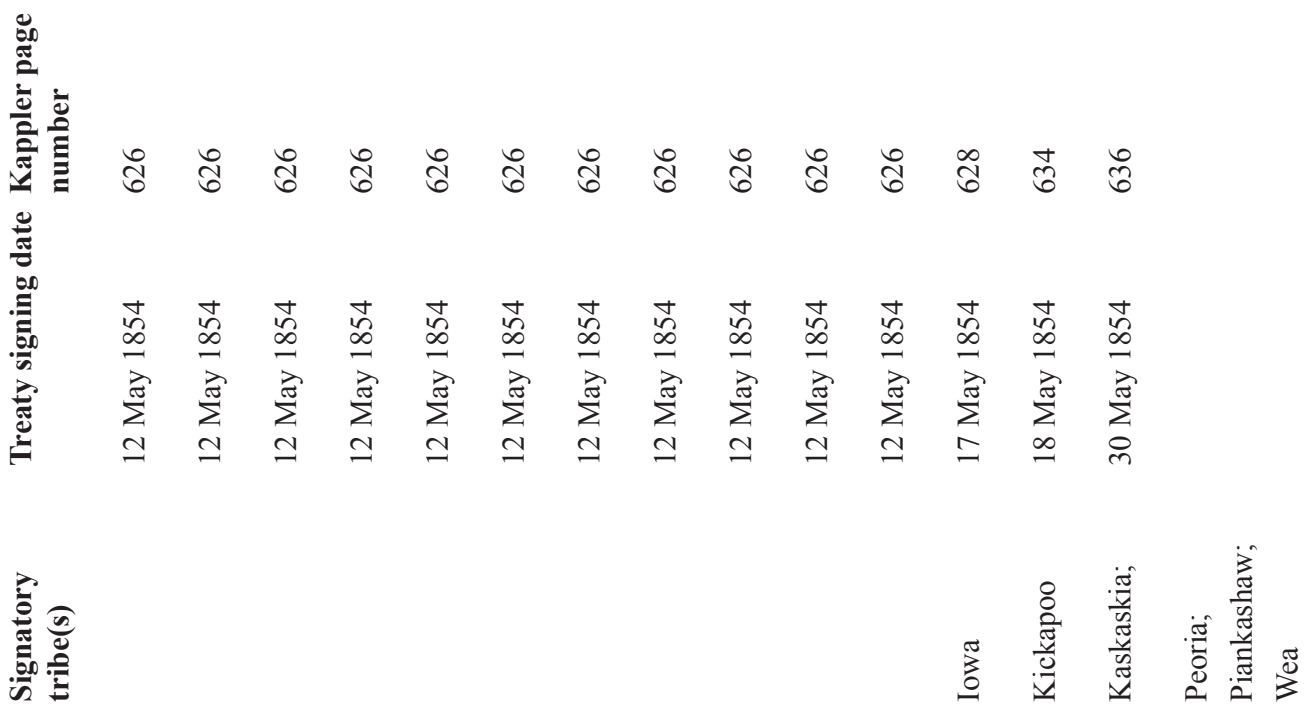

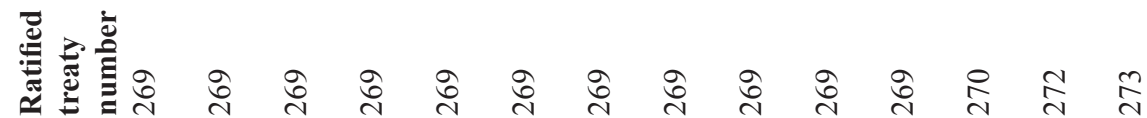




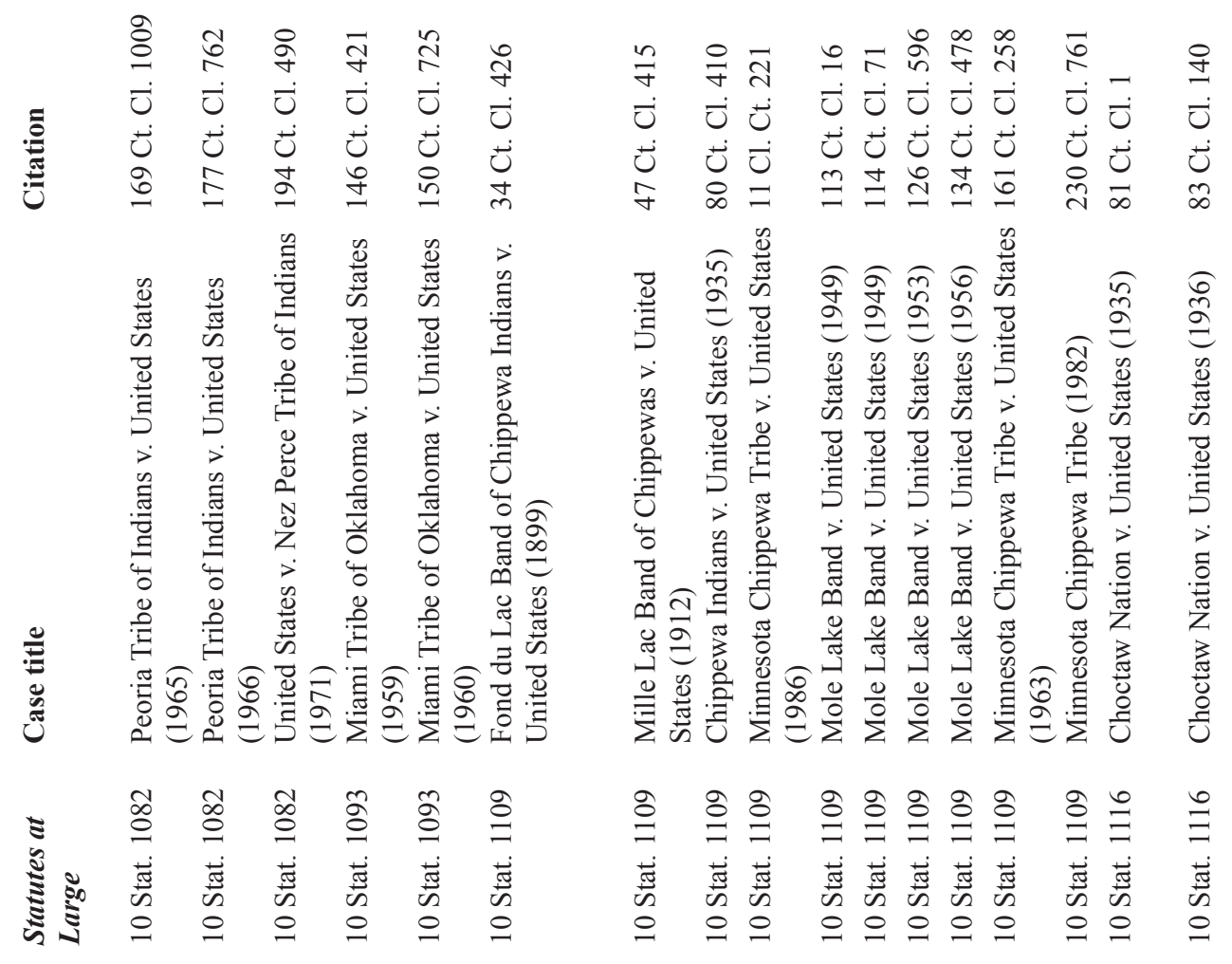

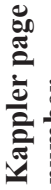

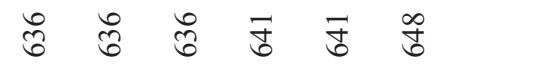

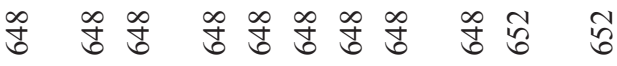

密

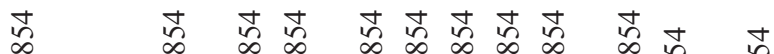

$\begin{array}{lllllllll} & & & & & & \\ 0\end{array}$

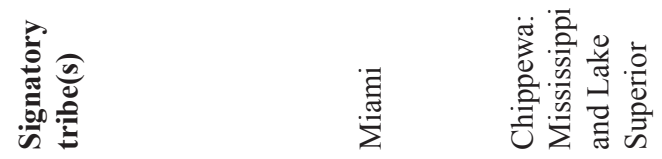

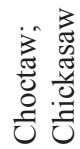

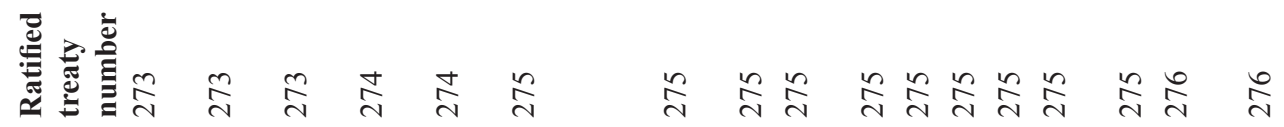




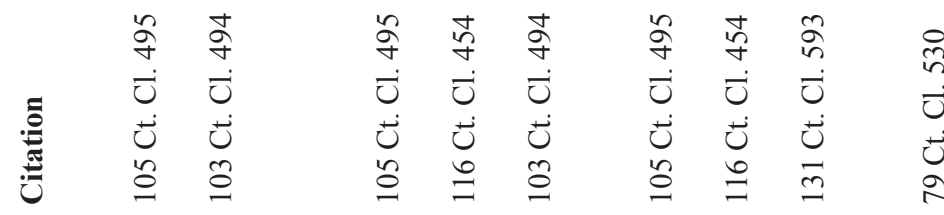

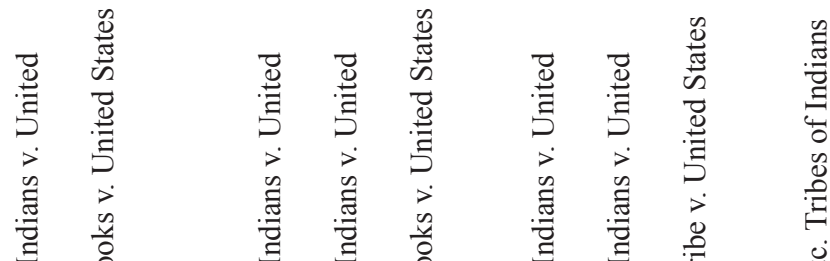

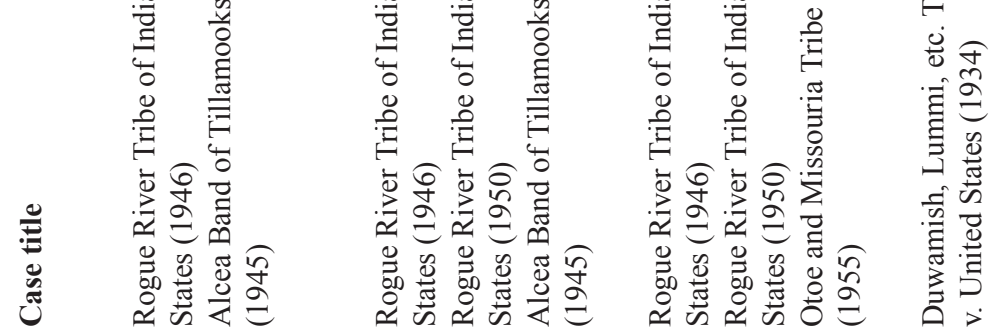

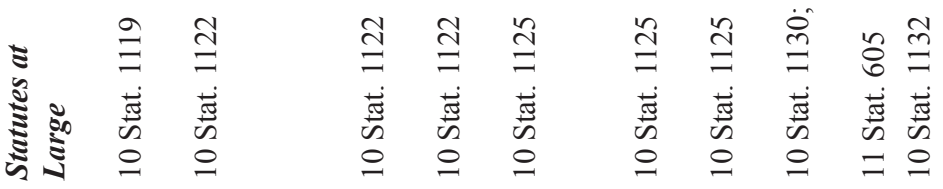

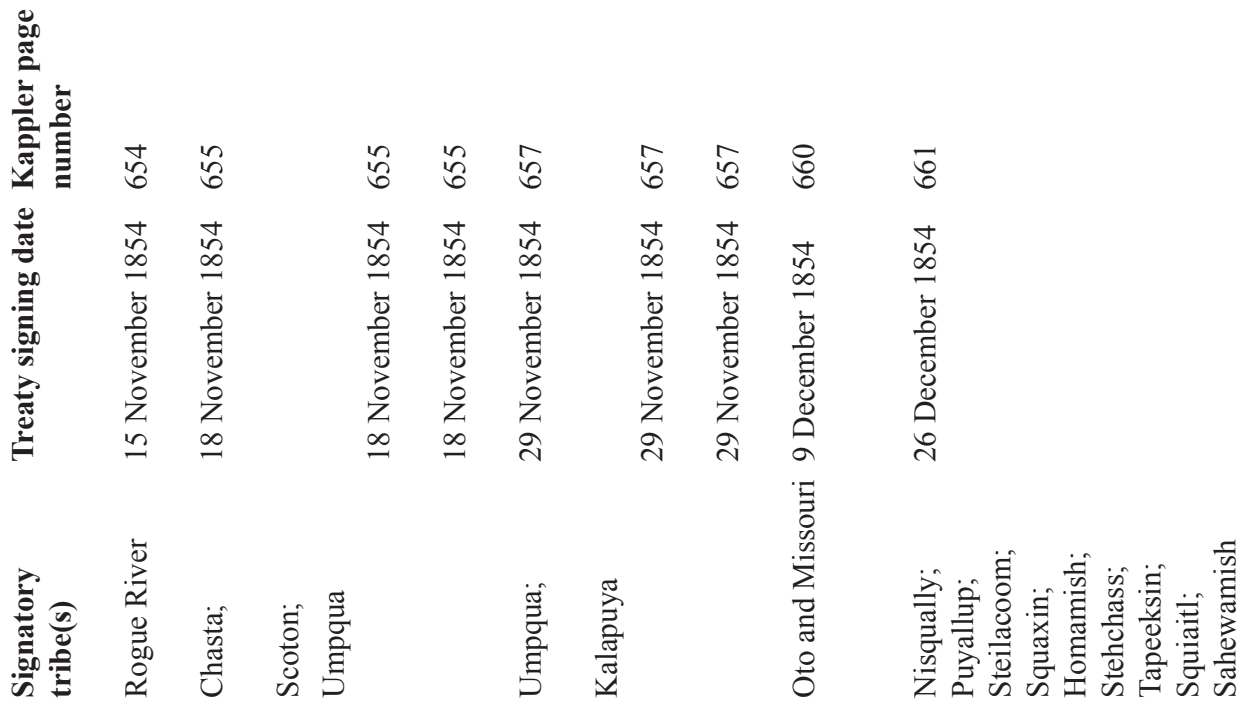

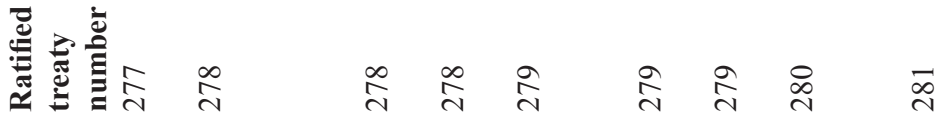



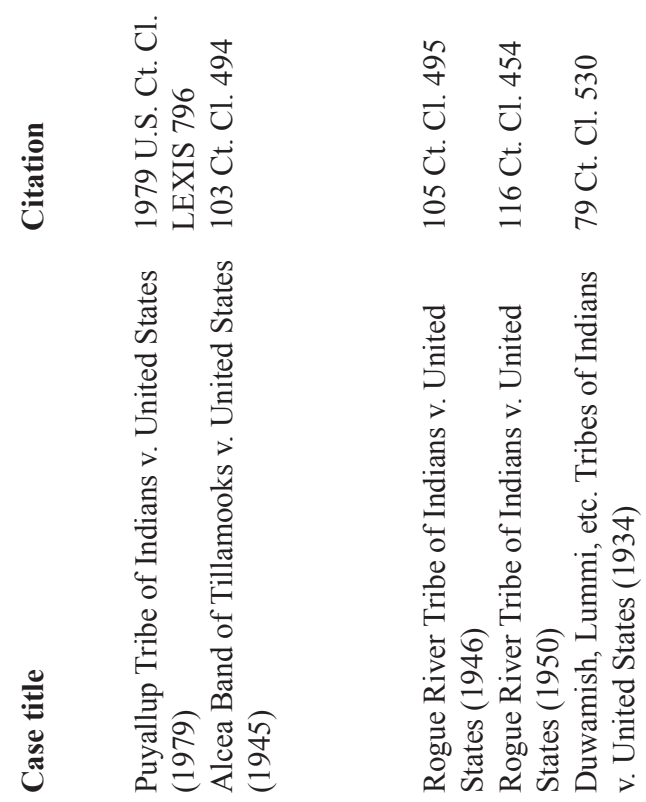

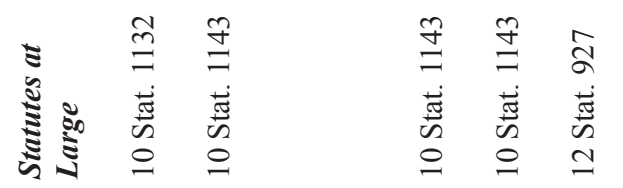
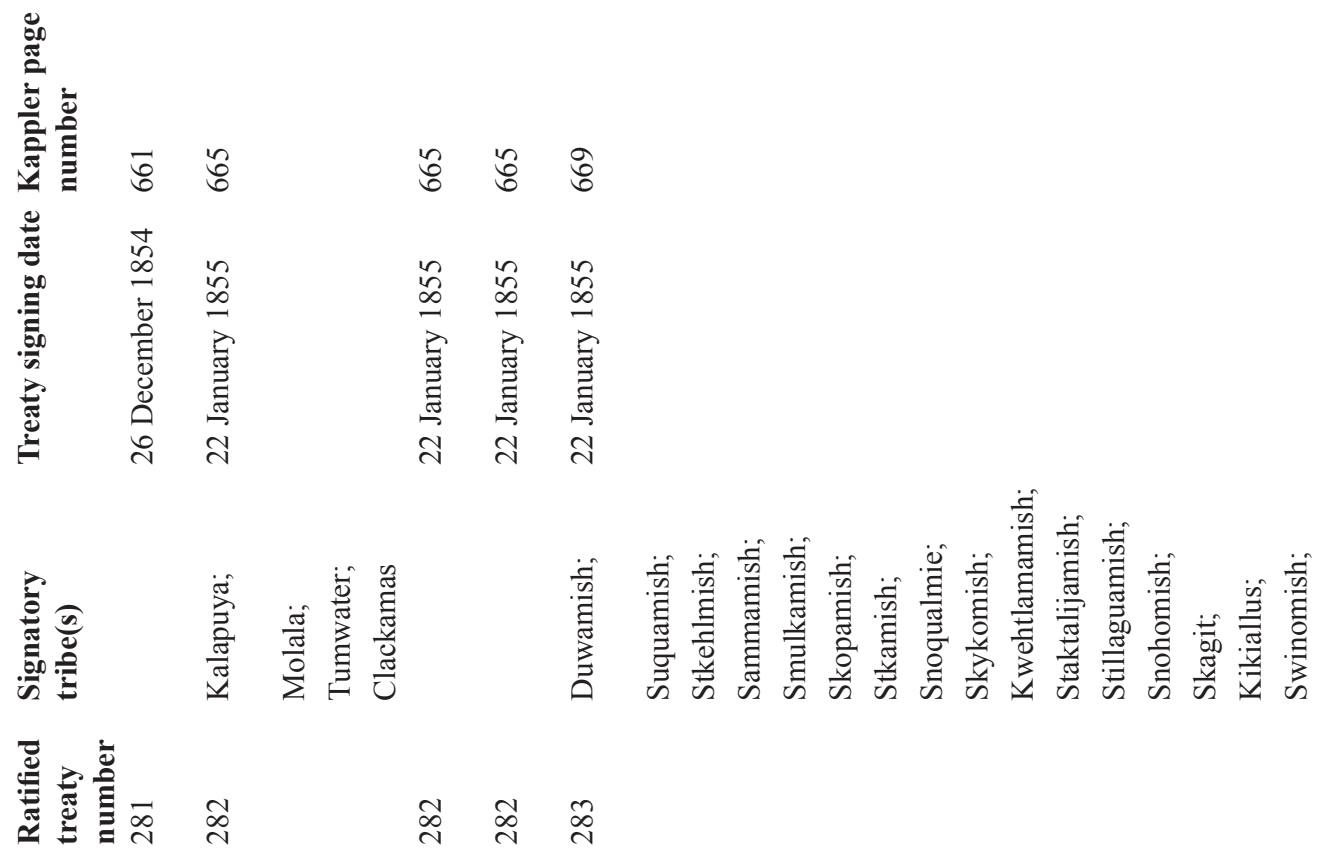
Uే.

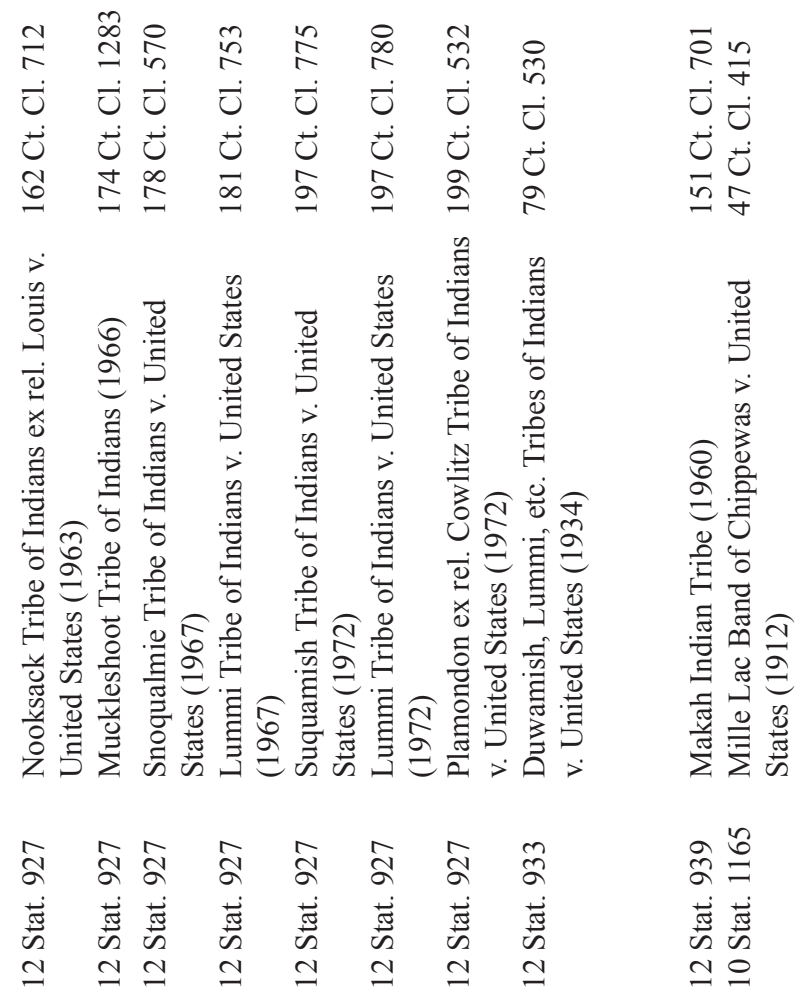

范

앙

泀

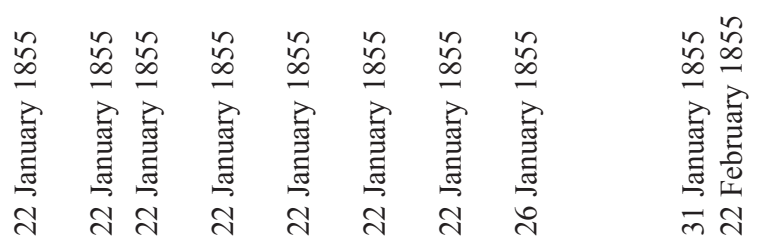

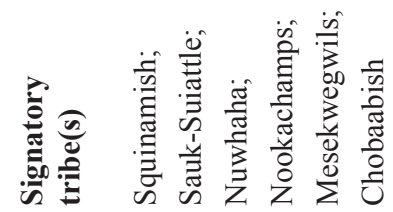

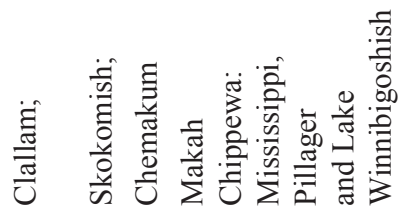
童亥商

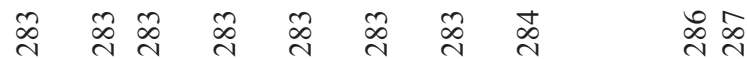




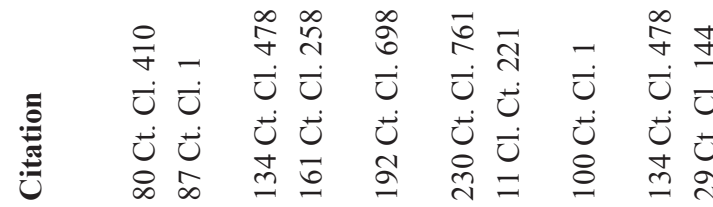

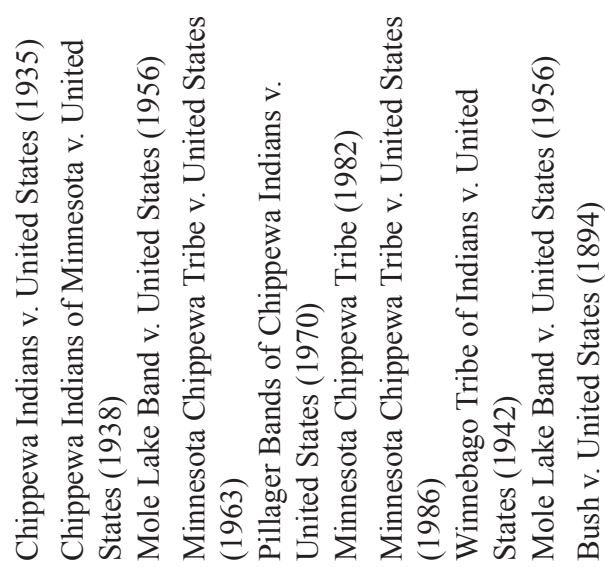

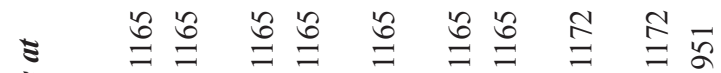

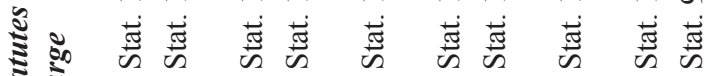

औง

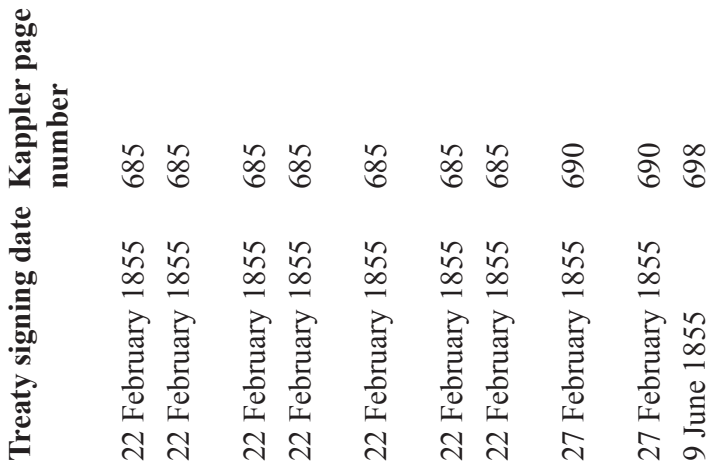

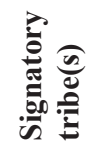

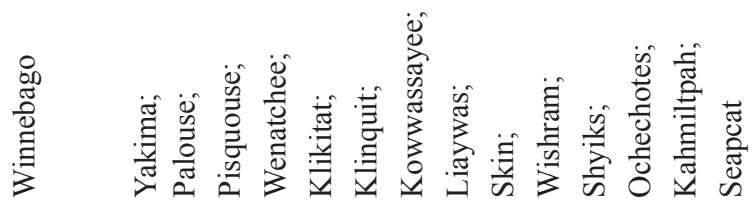

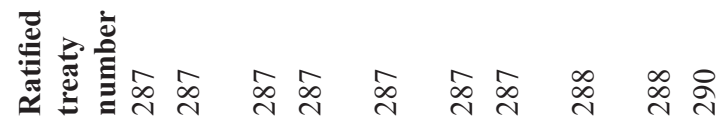




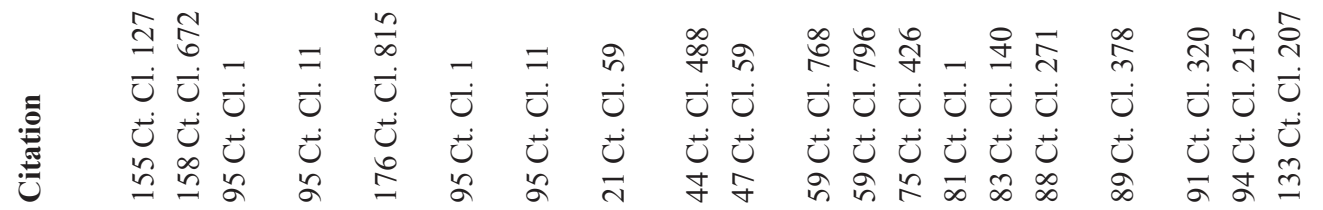

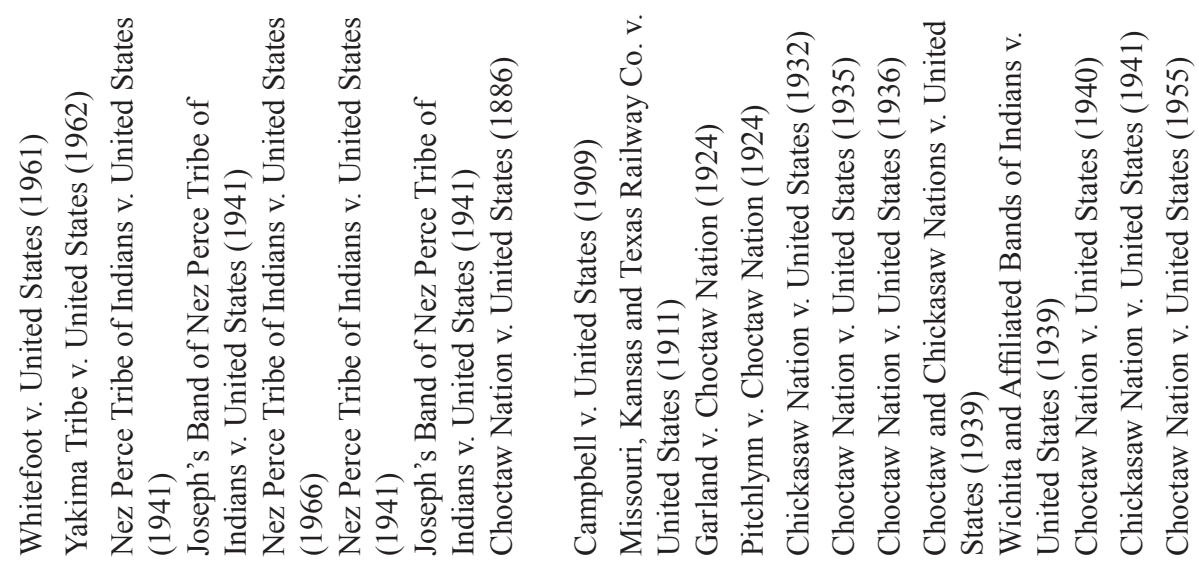

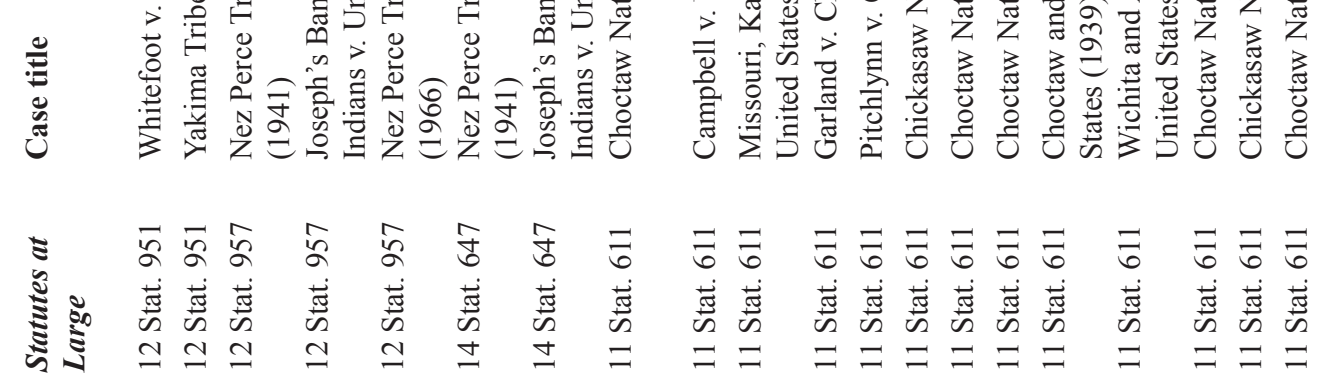

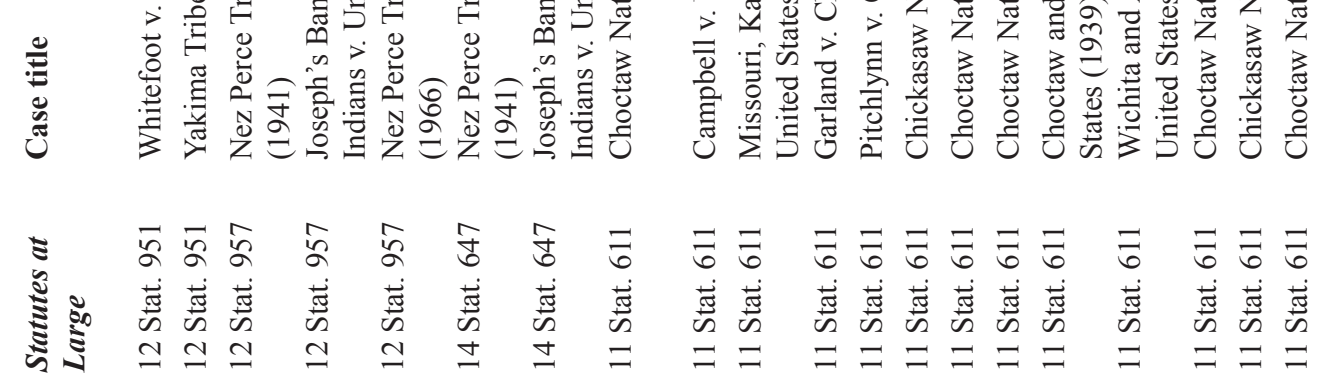
产

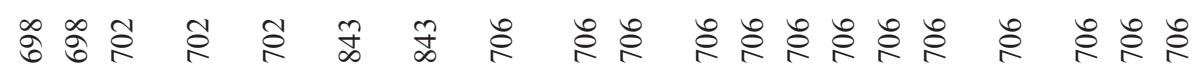
农

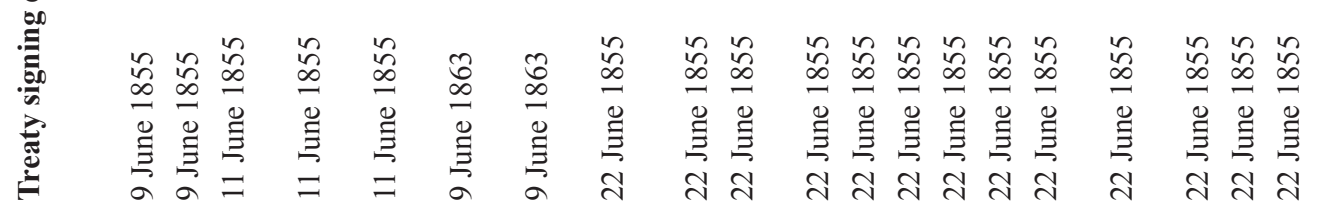

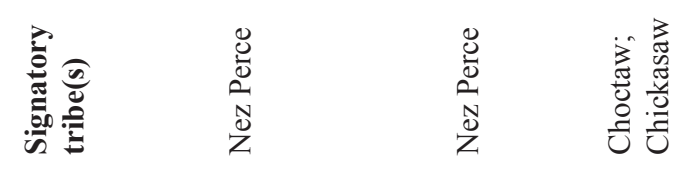

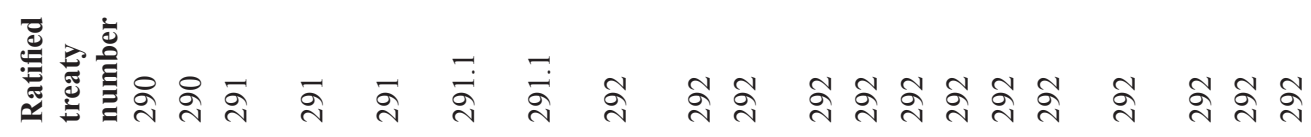




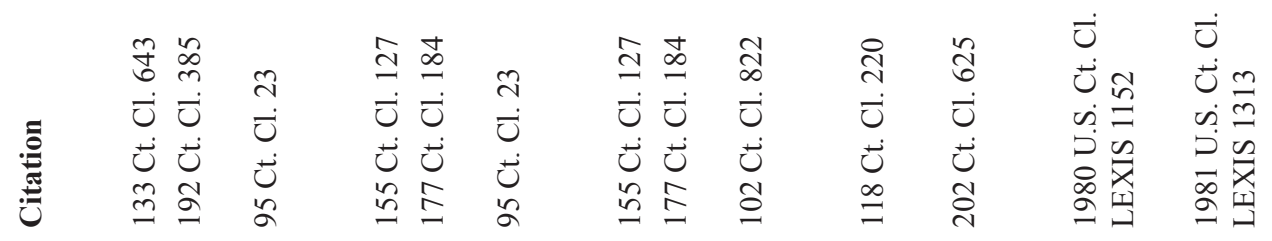

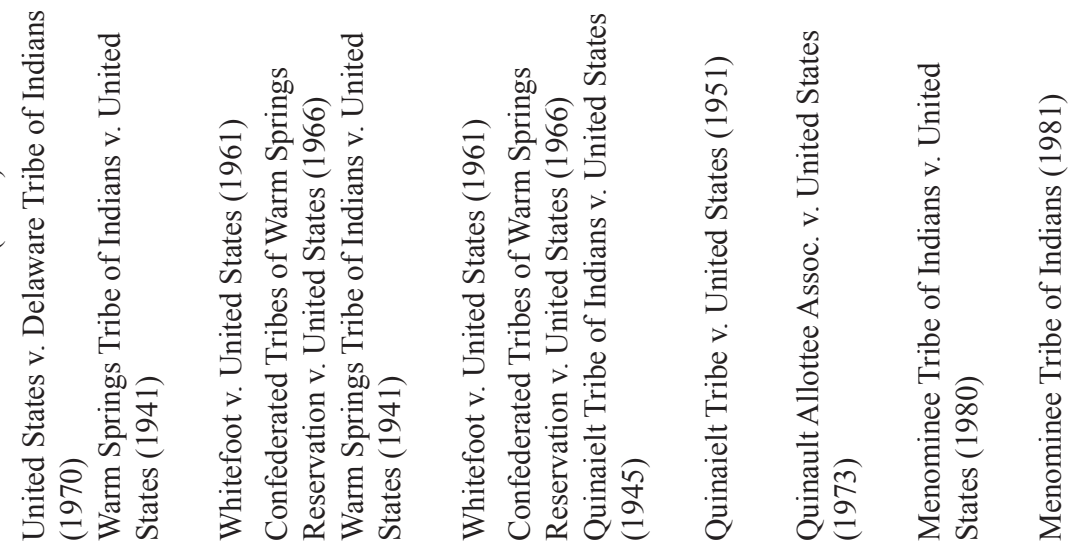

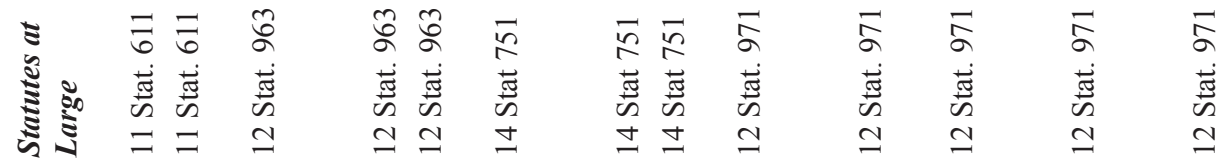

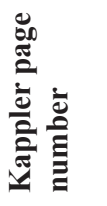

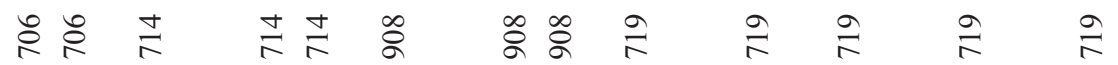

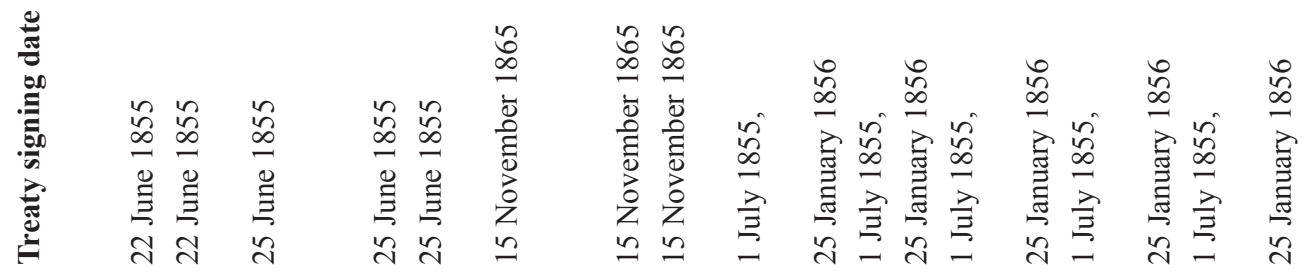

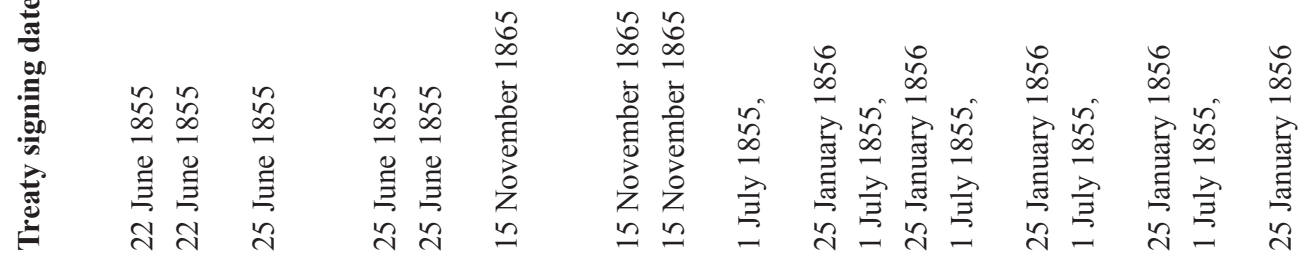

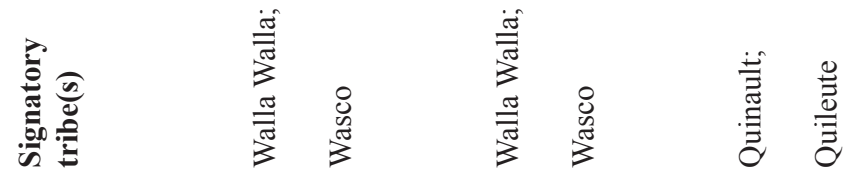

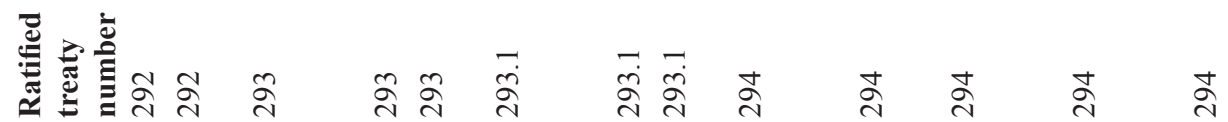




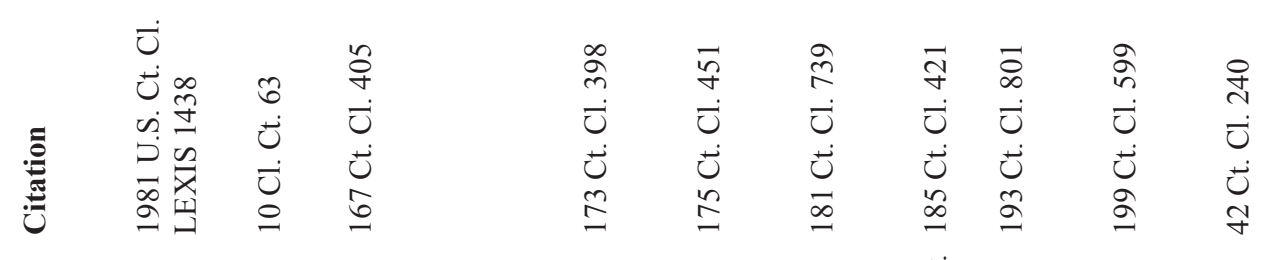

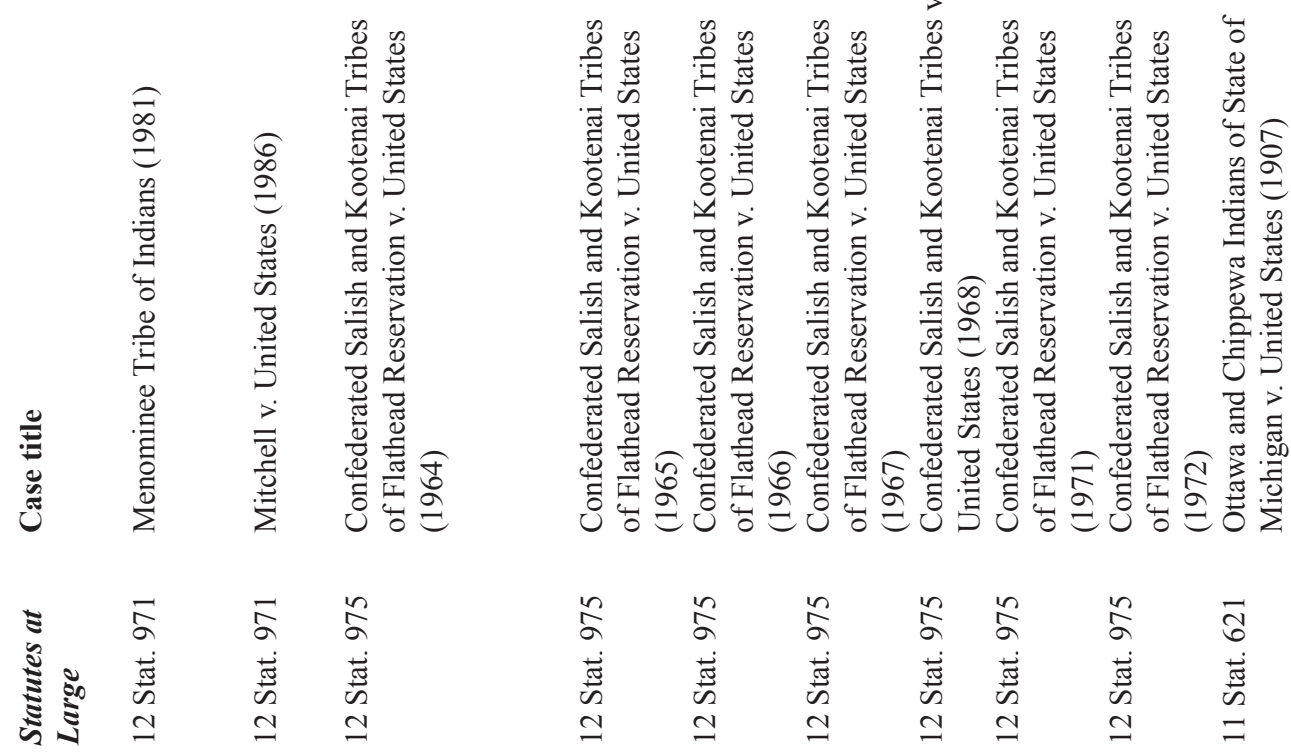
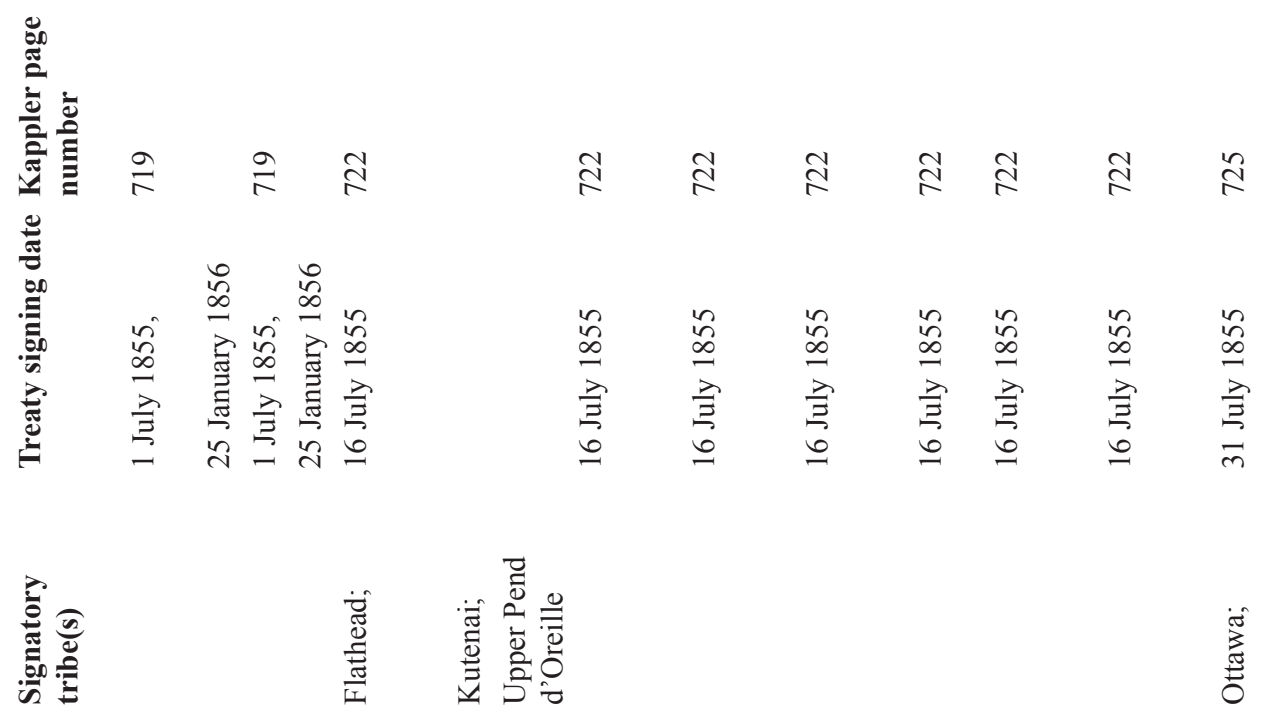

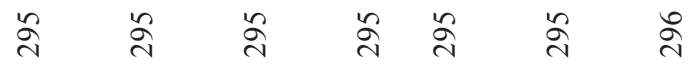



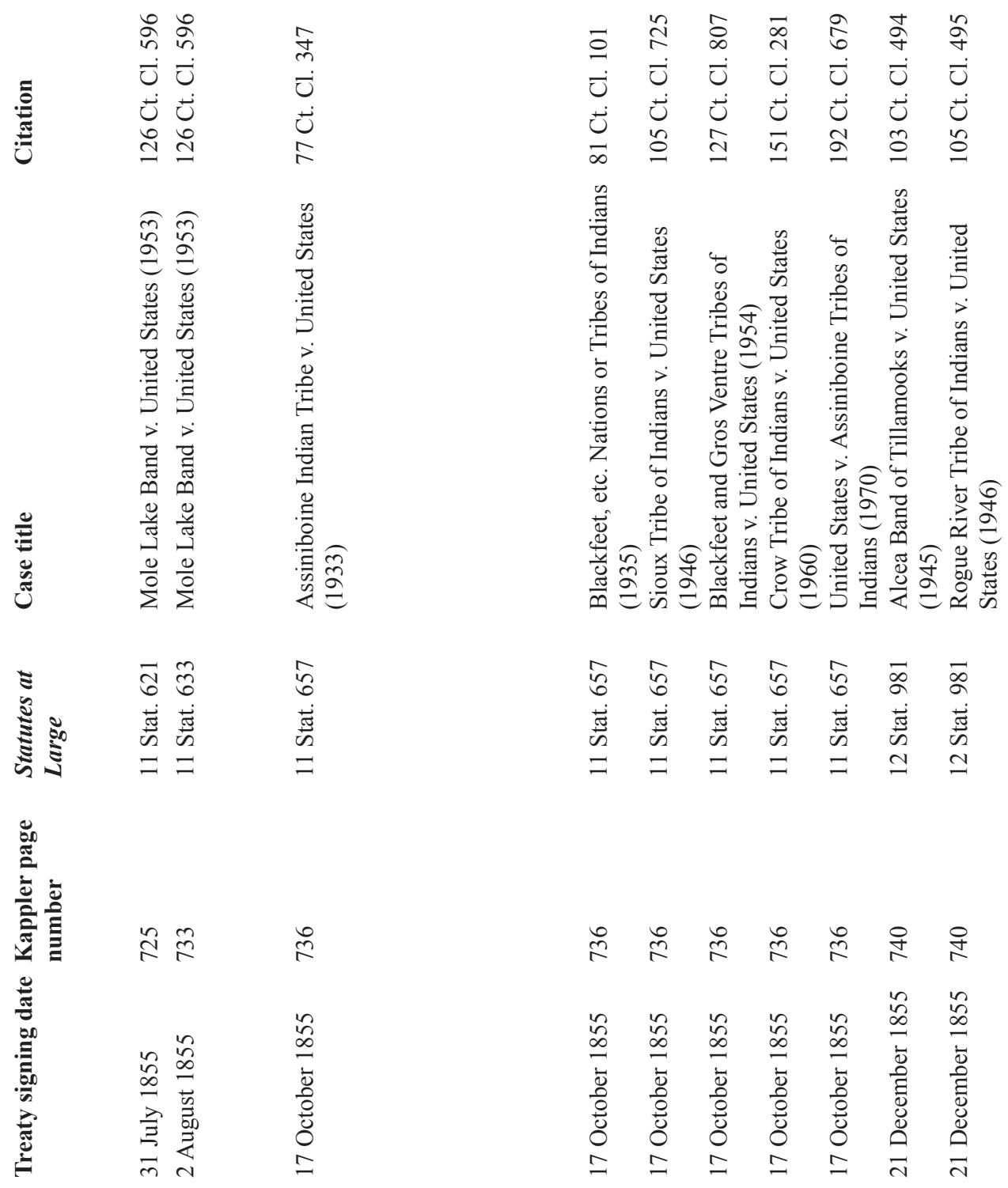

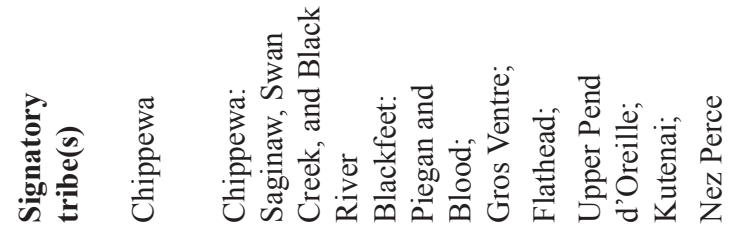

$\frac{\frac{\pi}{\pi}}{\frac{\pi}{0}}$

童敦

ลำ ำ

ริ

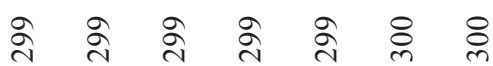




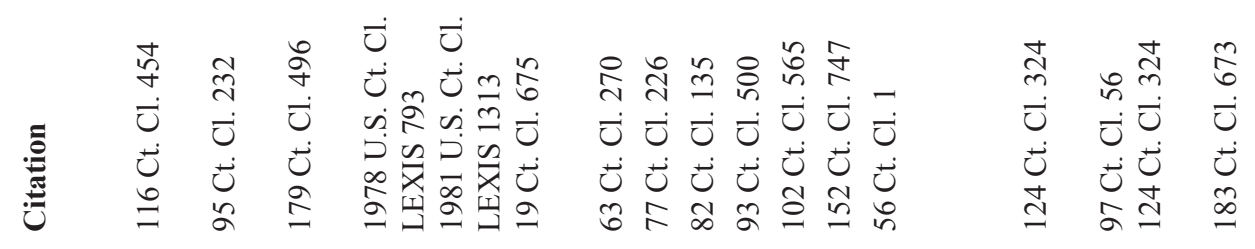

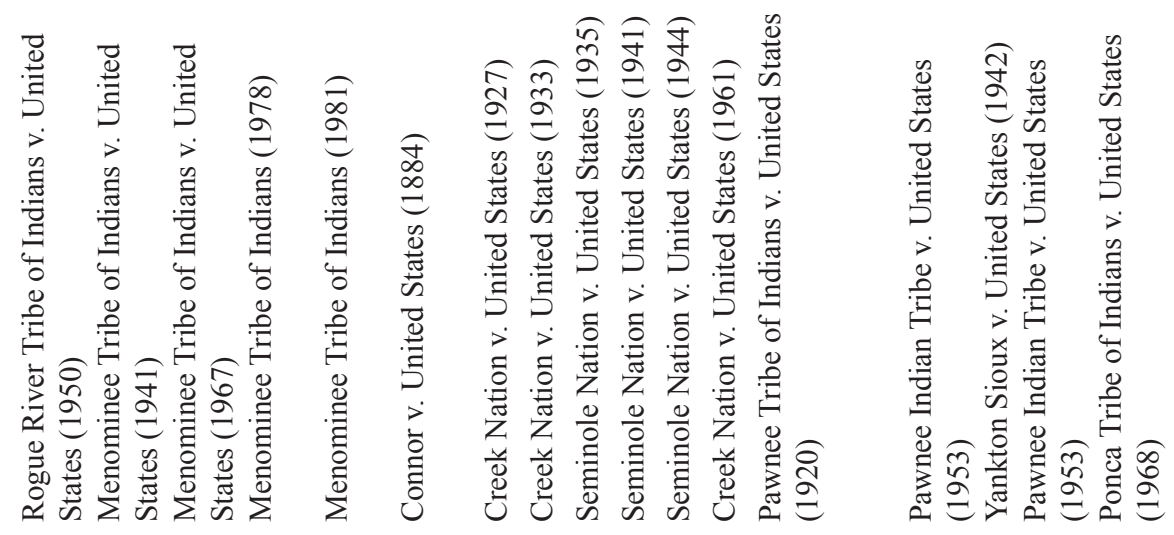

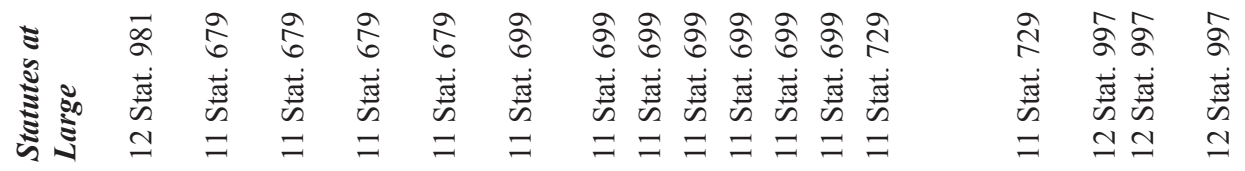
站

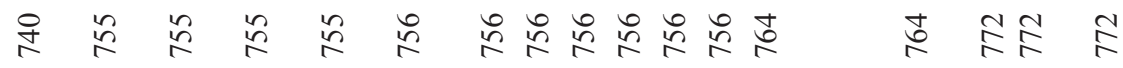

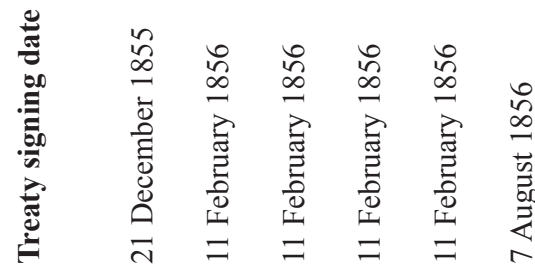

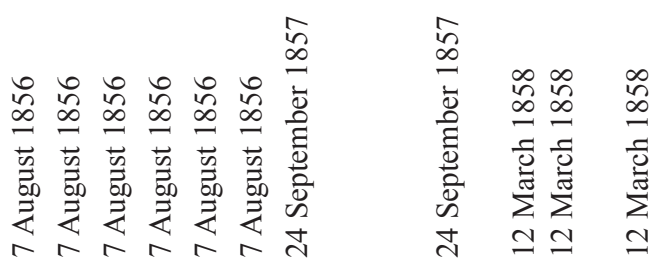

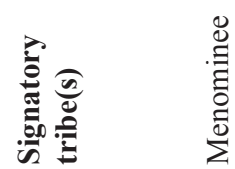
裳竞

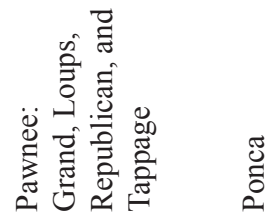

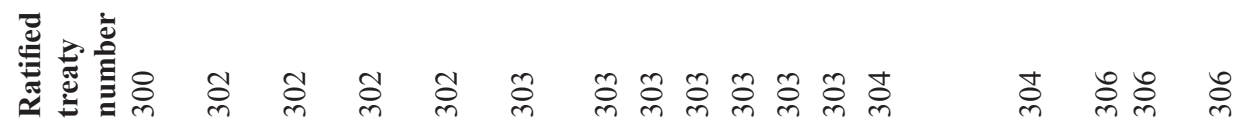




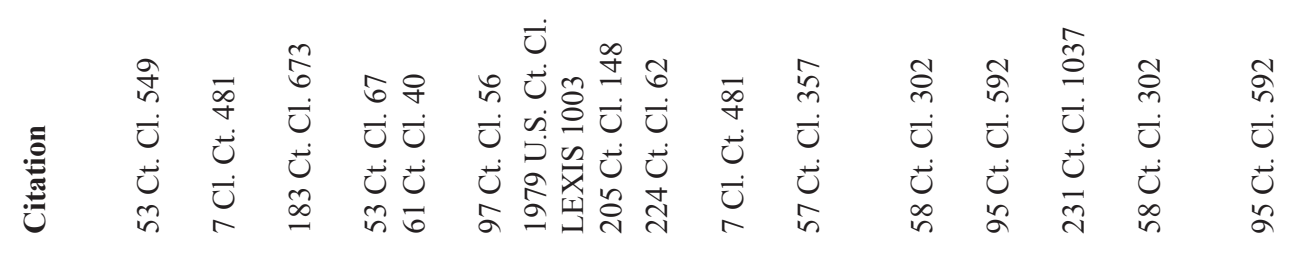

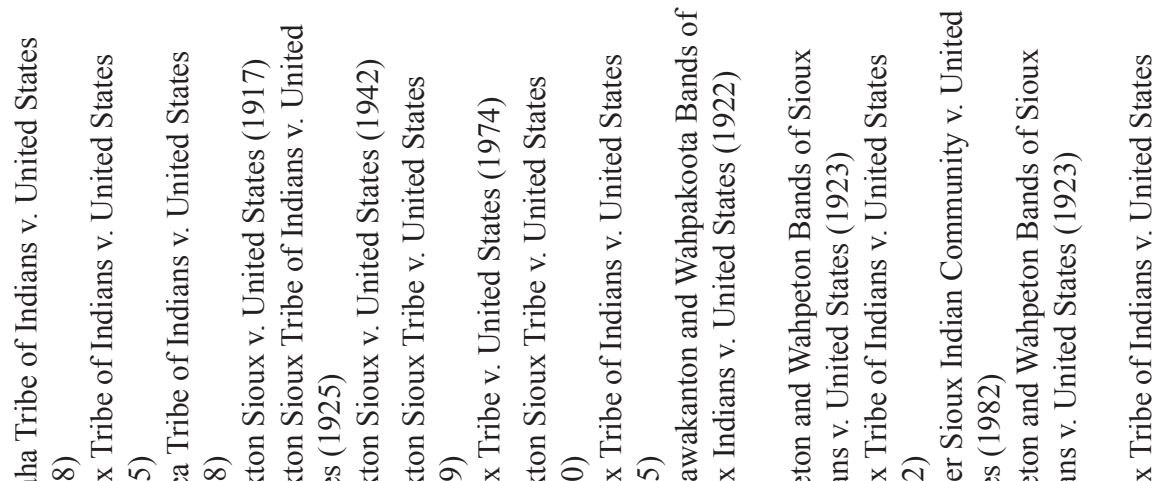

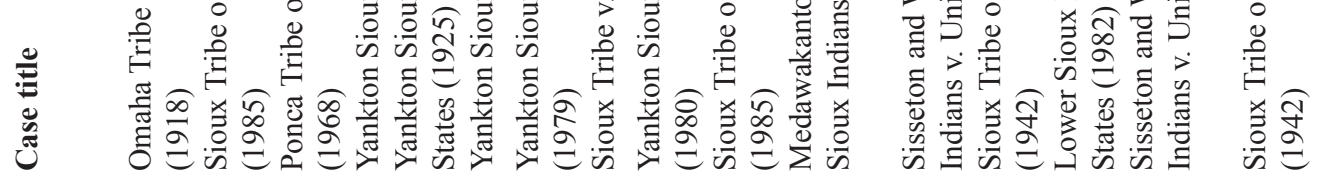

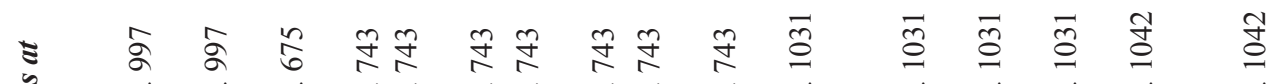

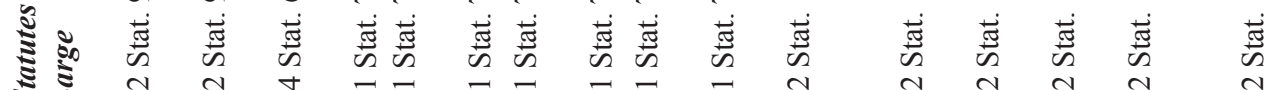

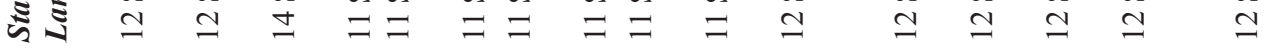

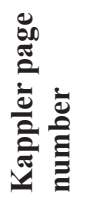

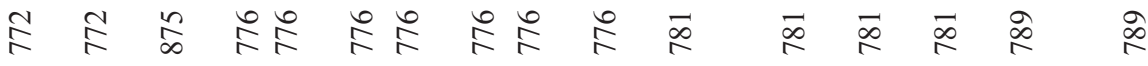
䒕

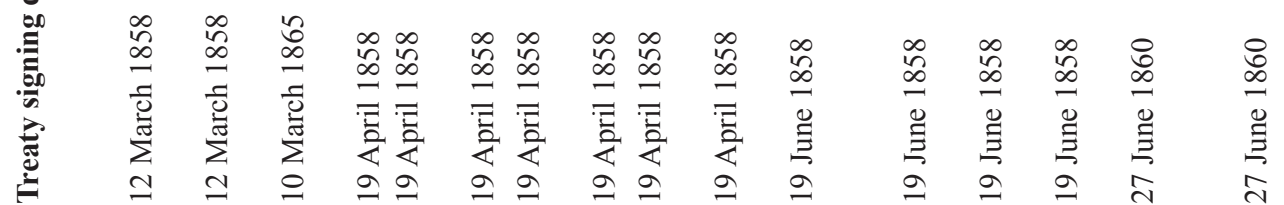

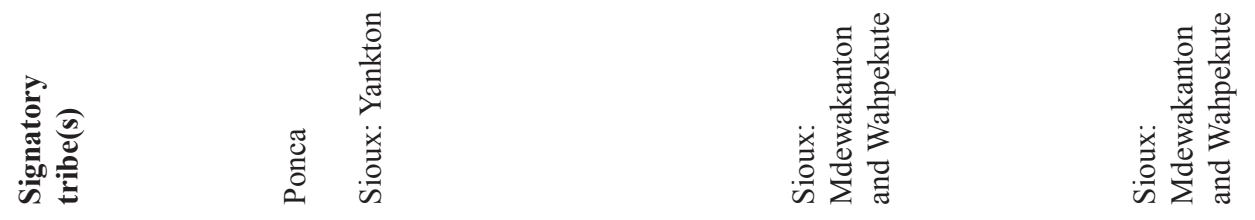

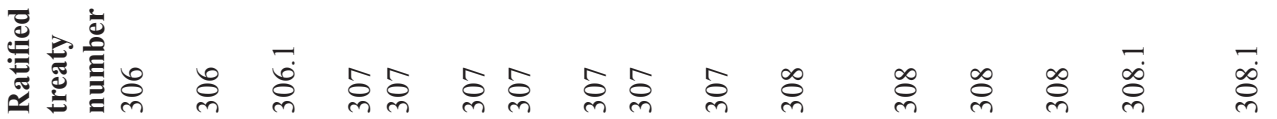




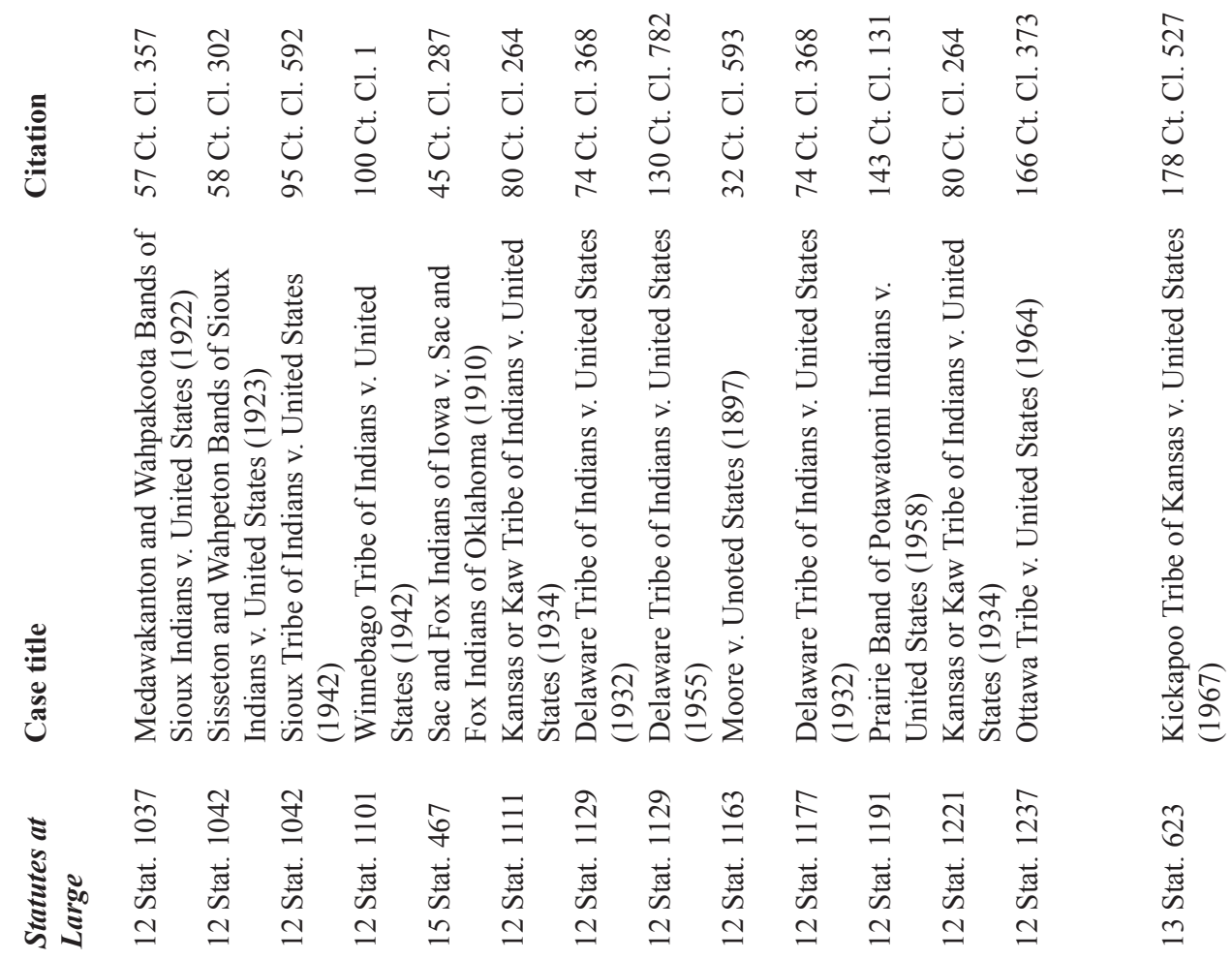

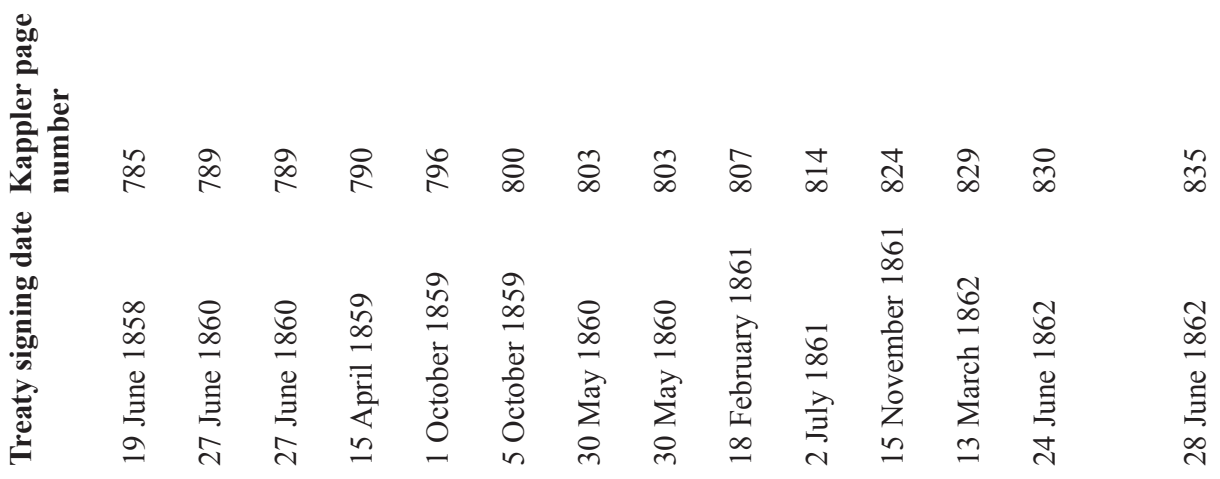

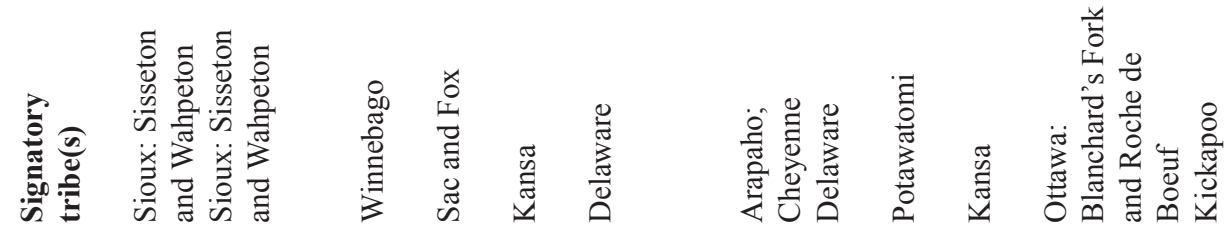

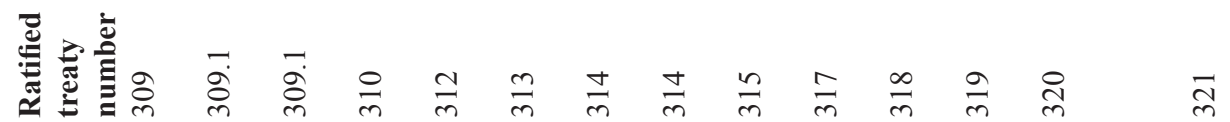




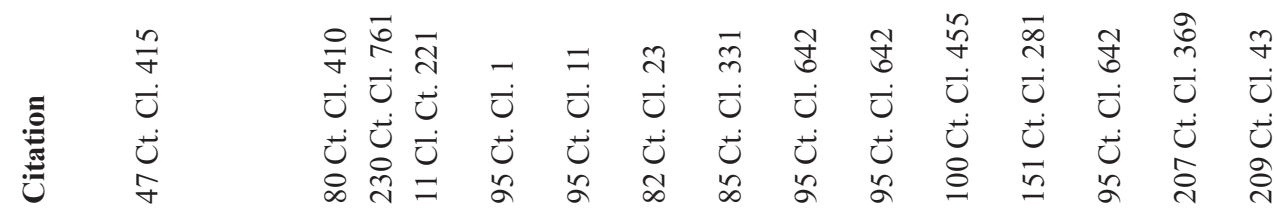

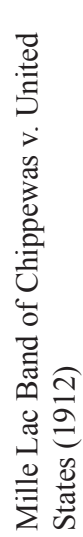

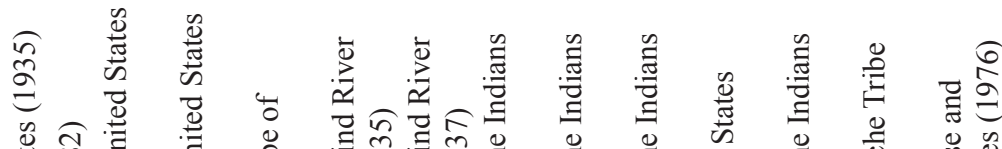

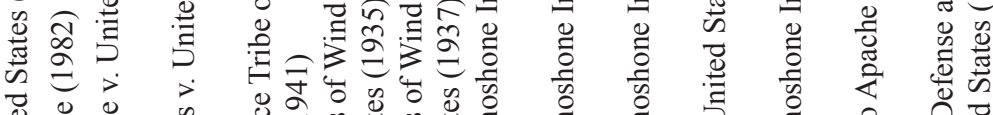

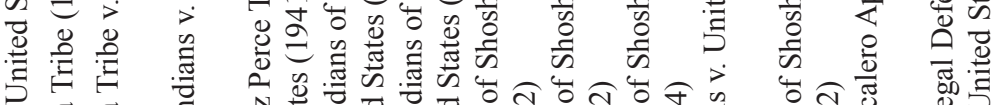

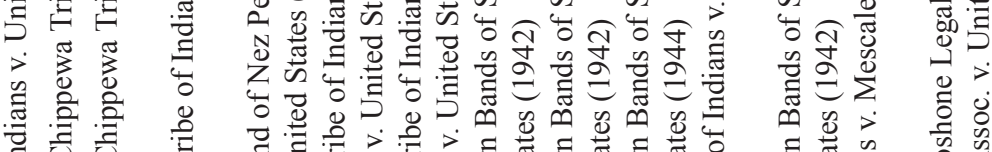

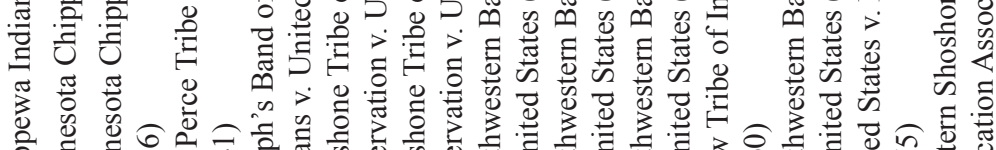

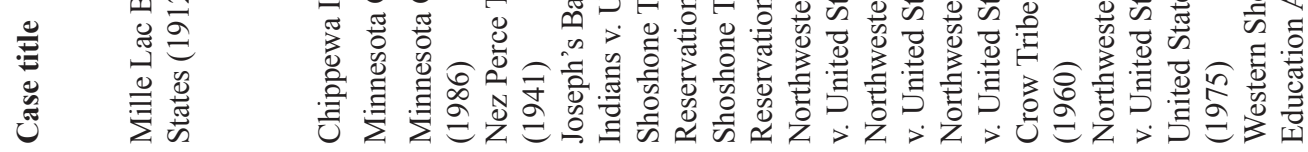

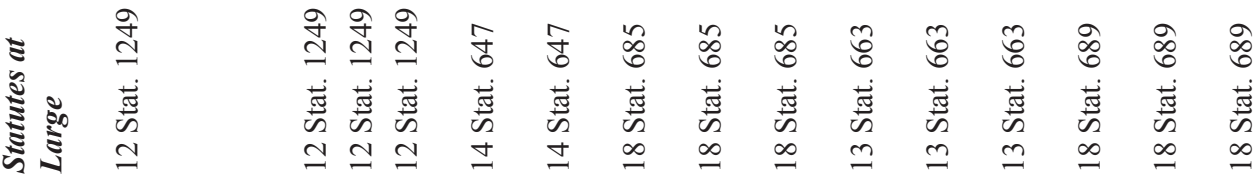

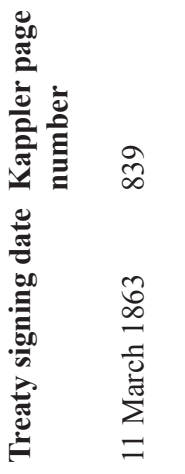

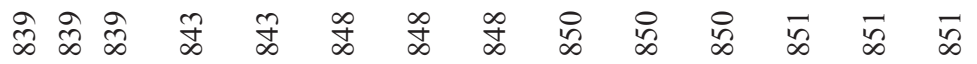

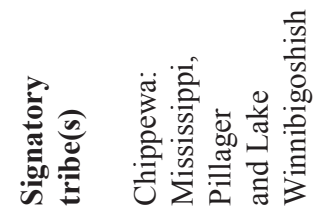

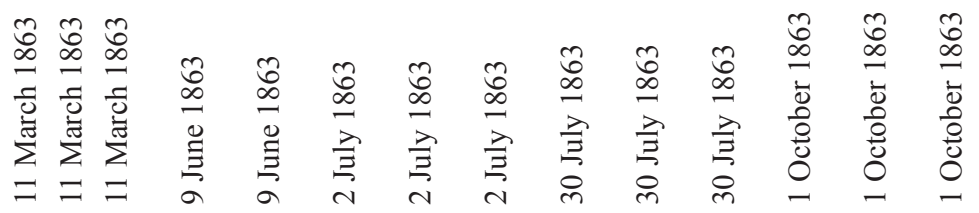

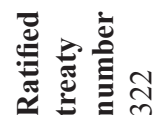

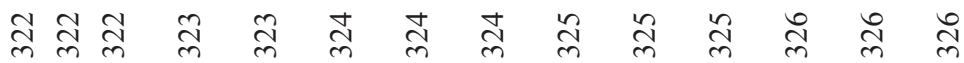




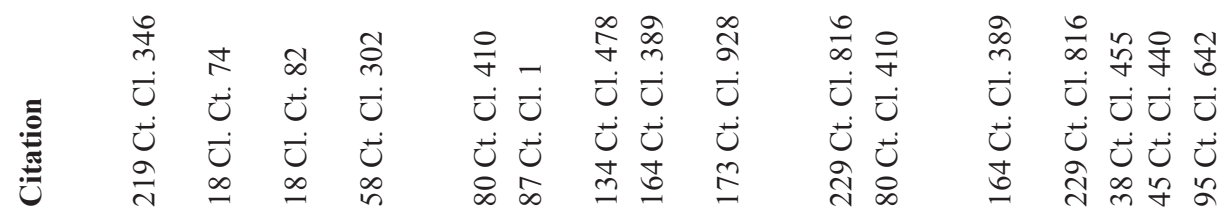

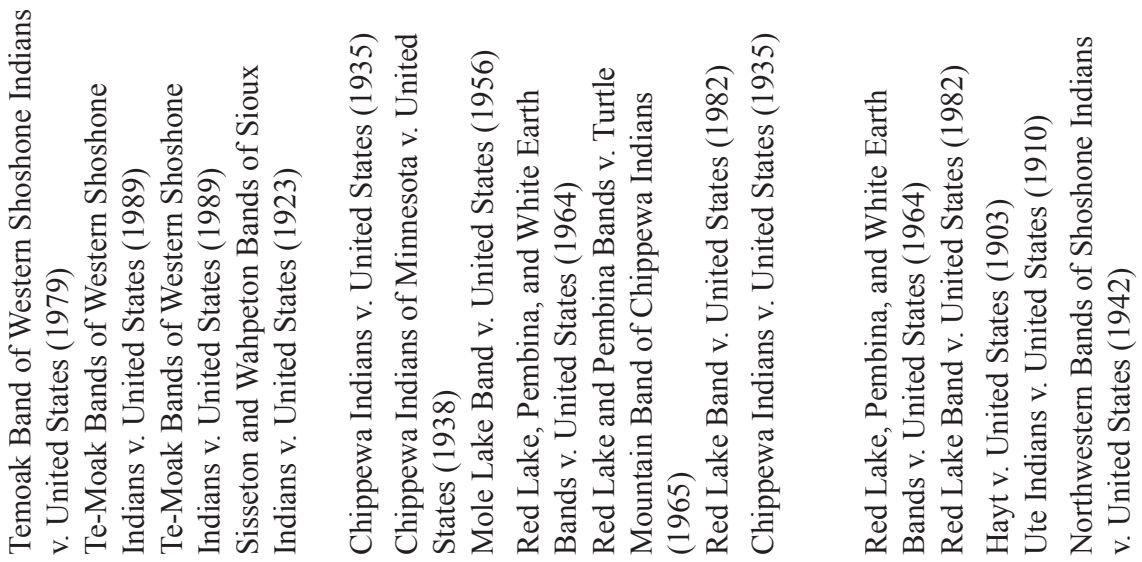

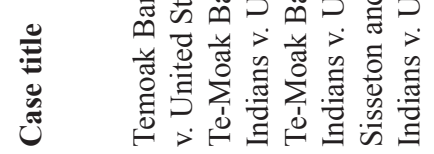

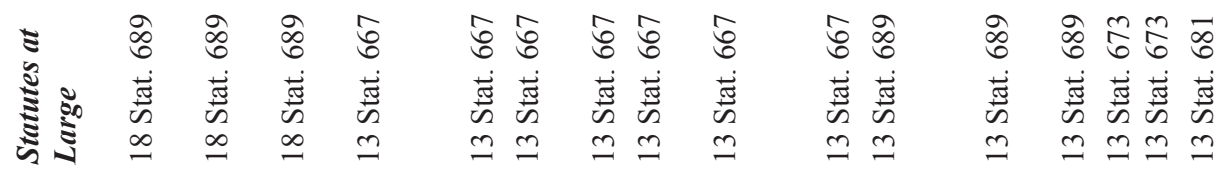

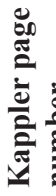

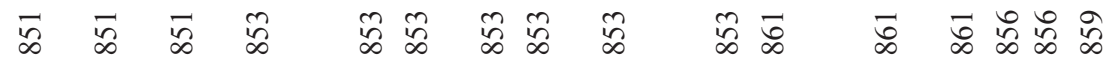

䒕

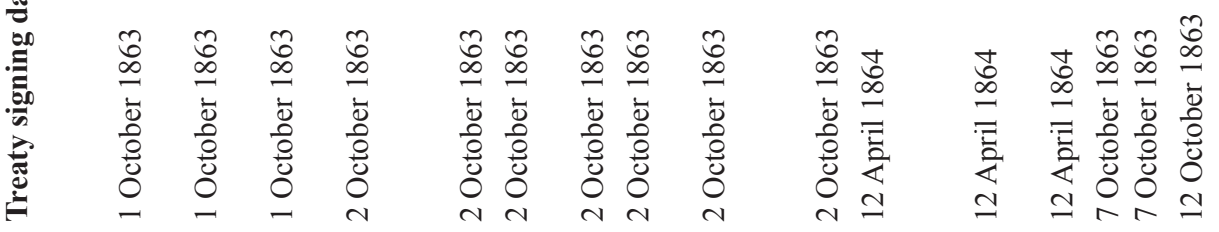
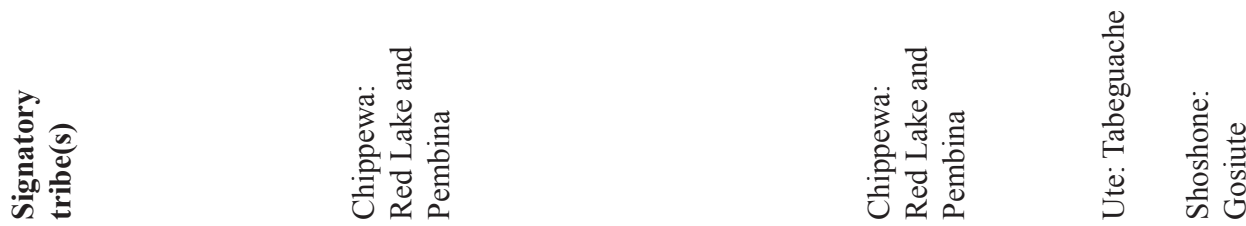

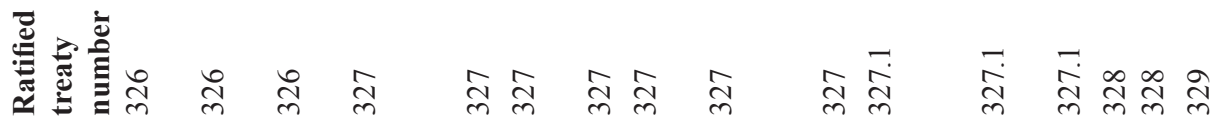



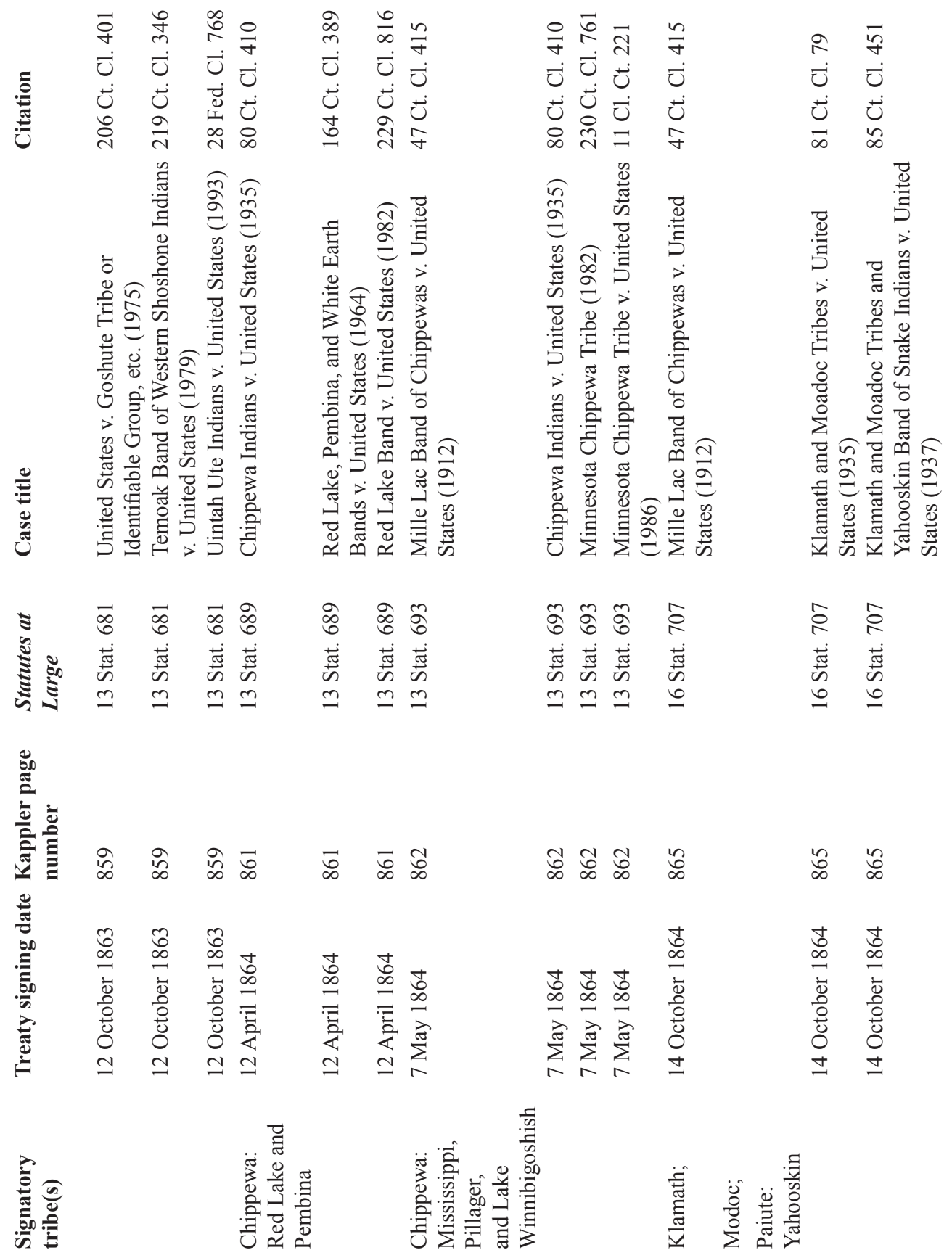

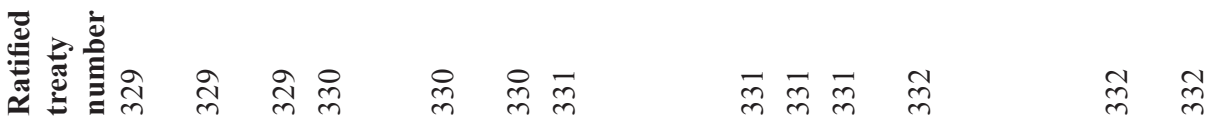




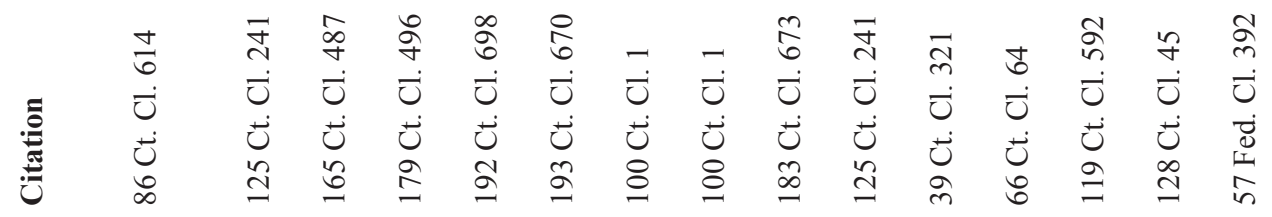

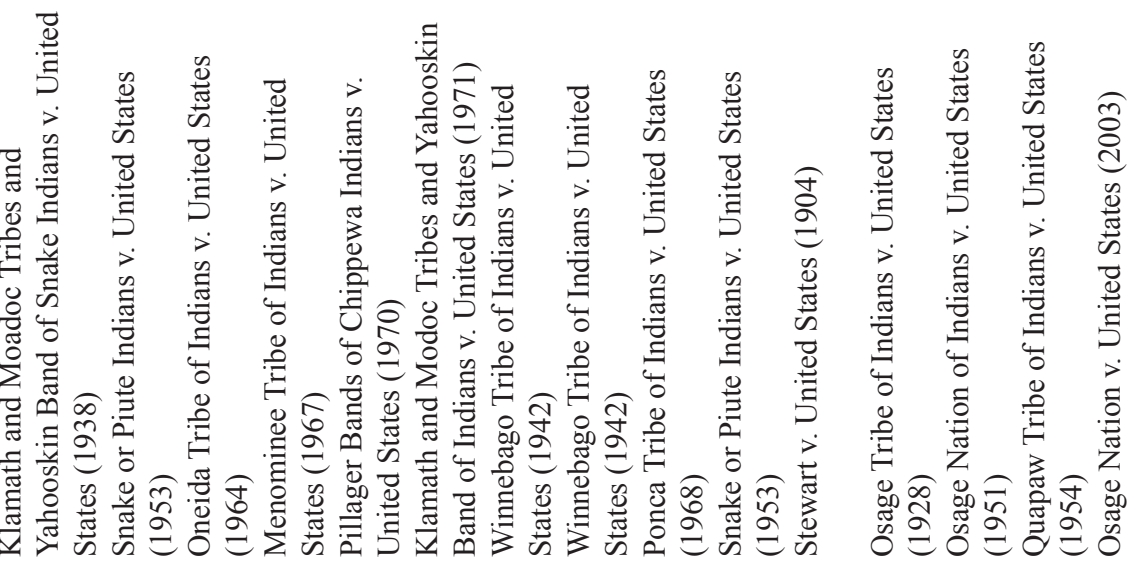

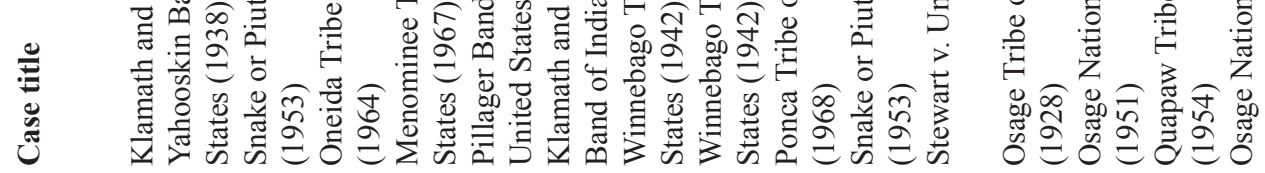

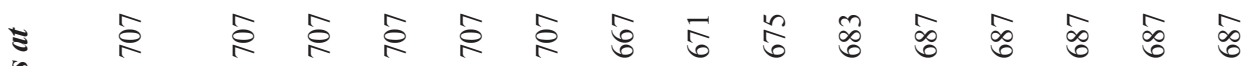

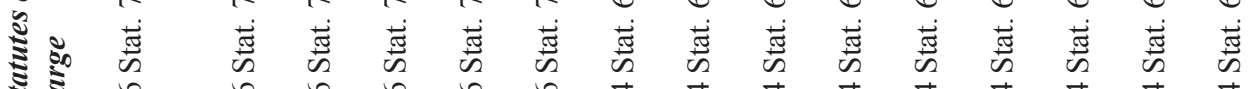
岁

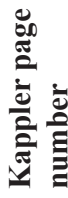

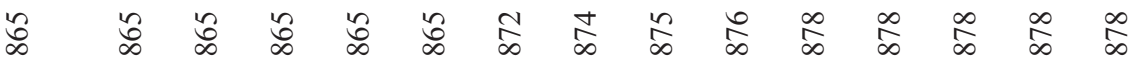

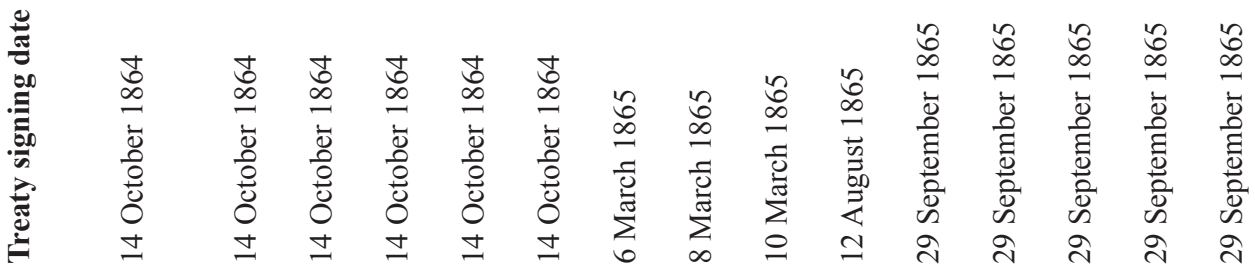
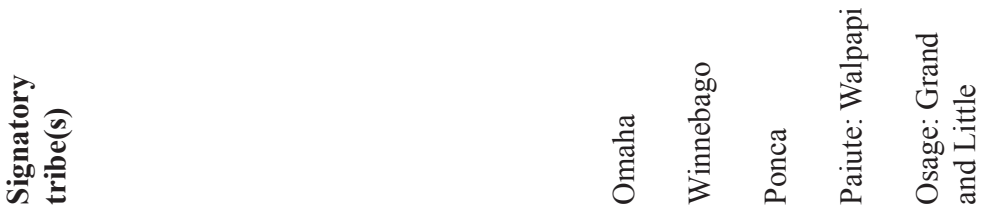


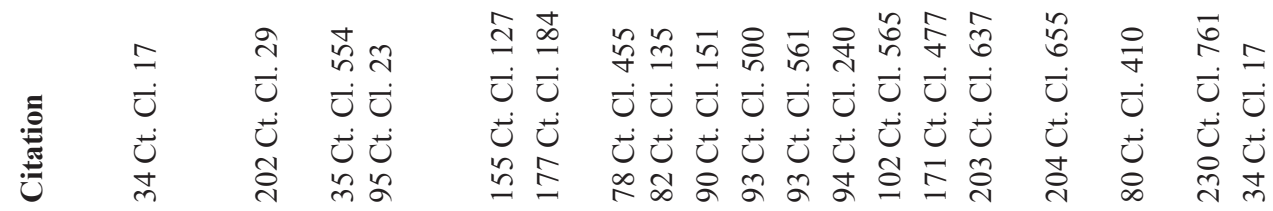

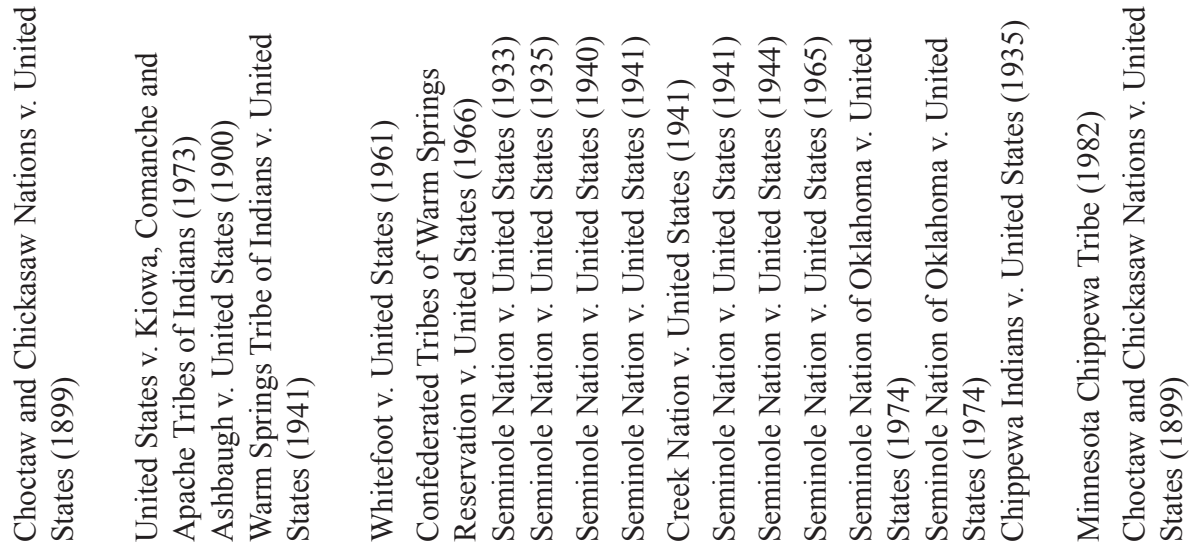

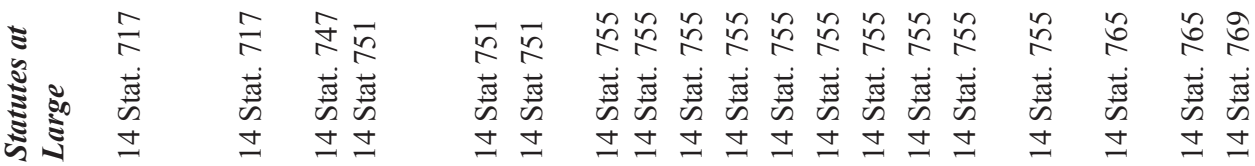

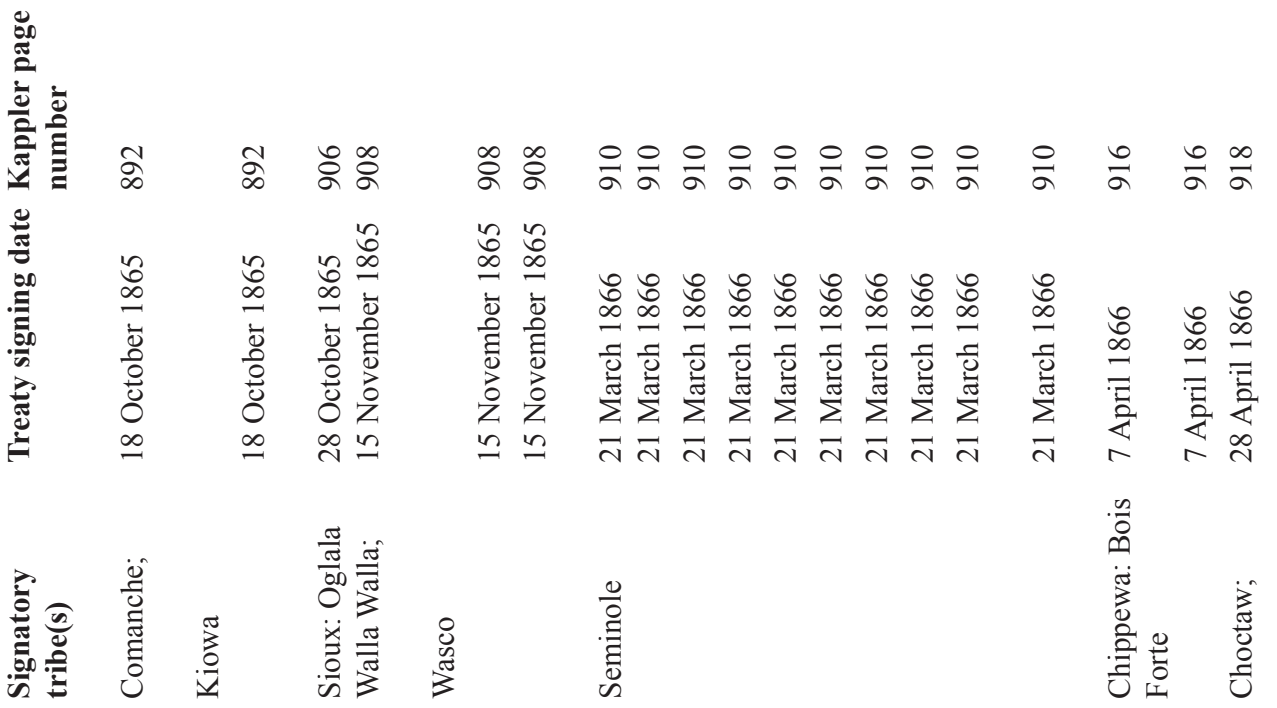

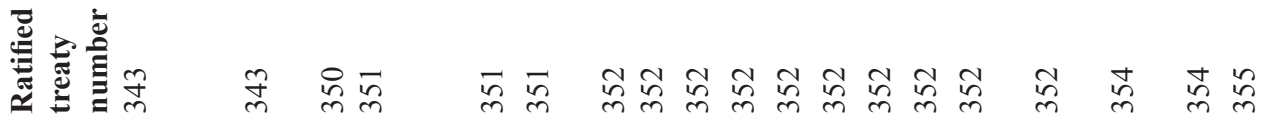




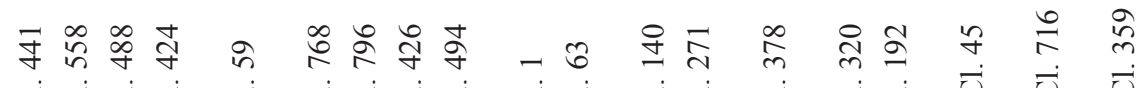

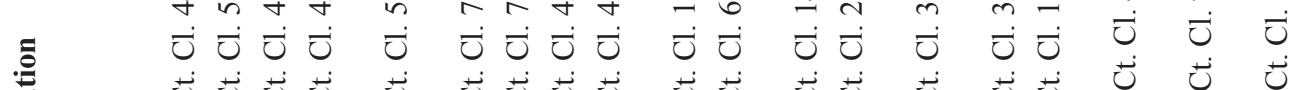

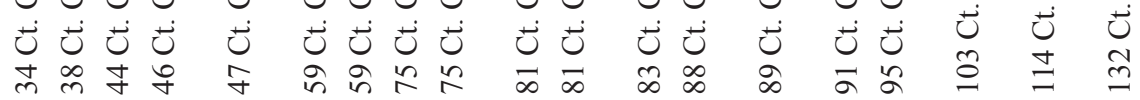

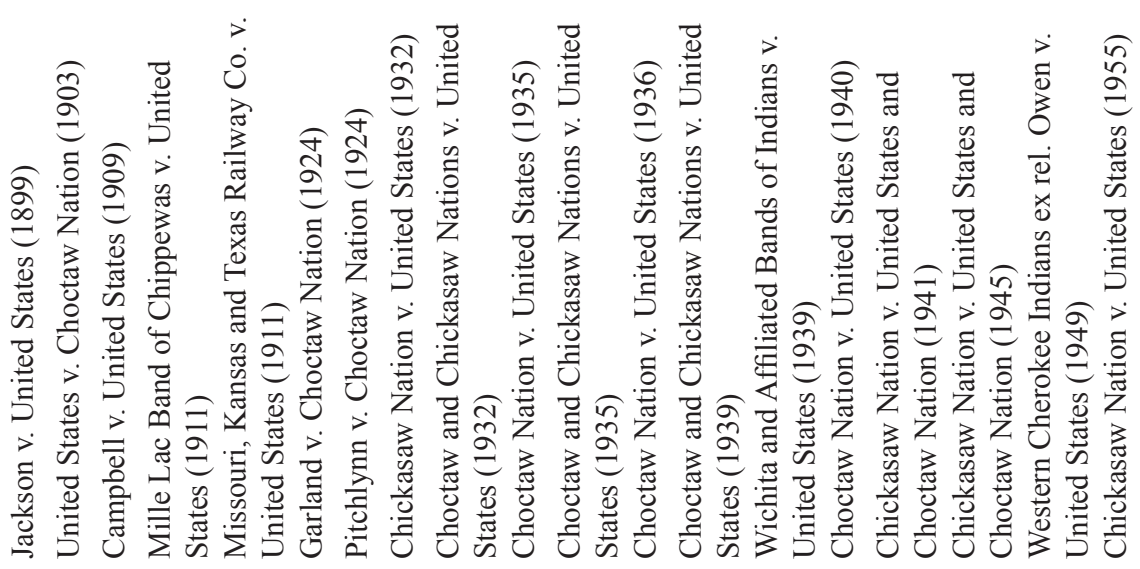

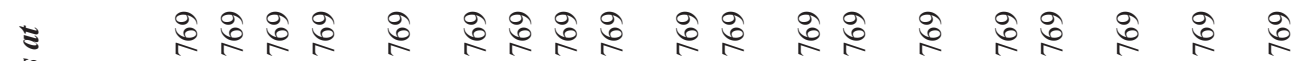

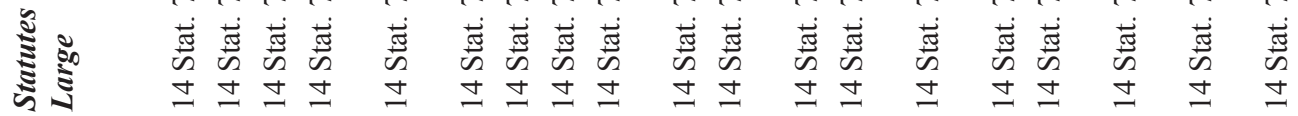

:

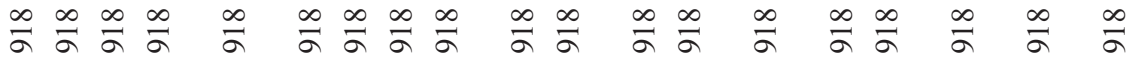

䒕

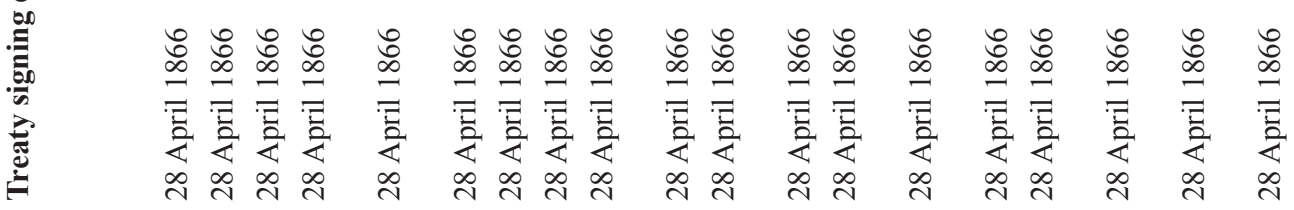

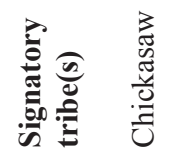

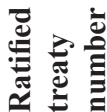

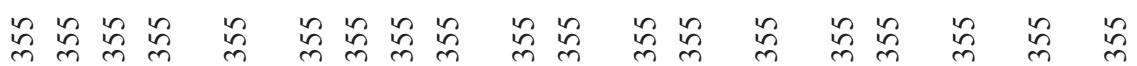




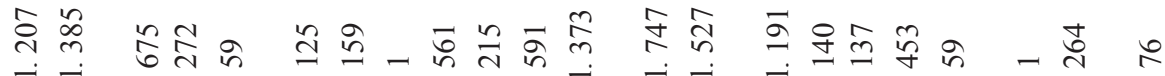

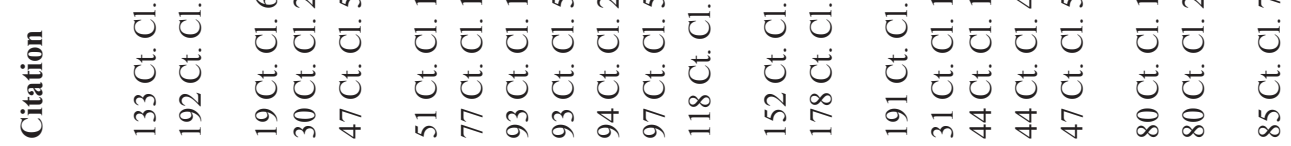

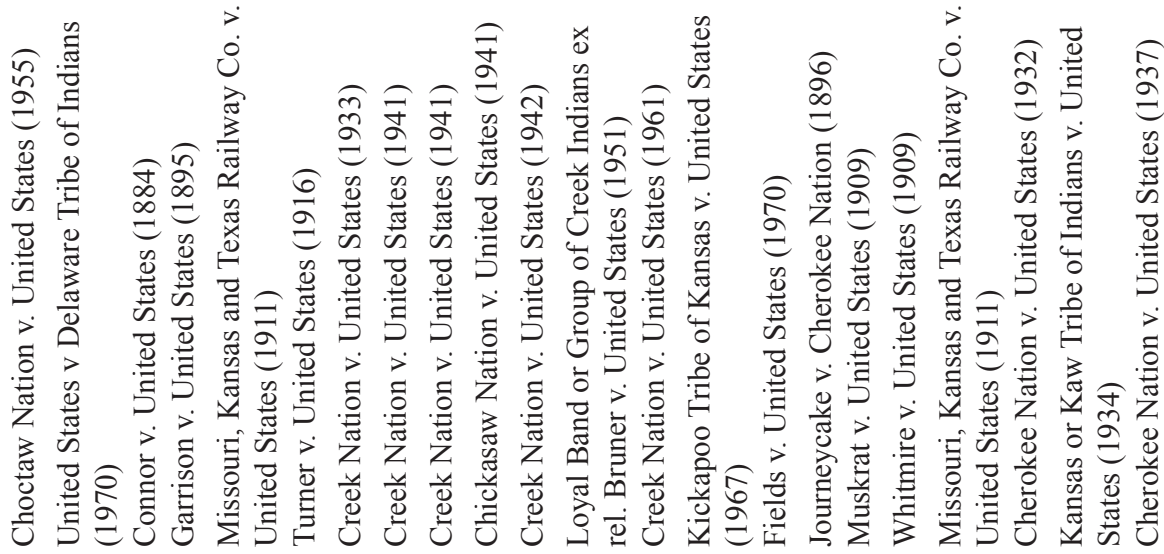

छ केष

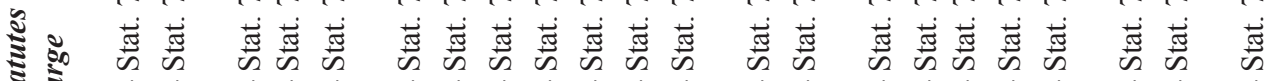

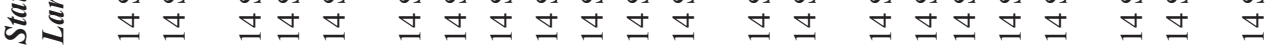

高就

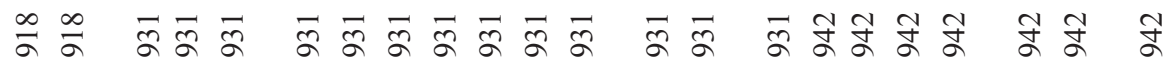

类

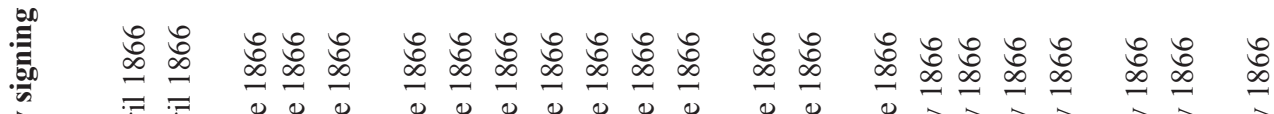

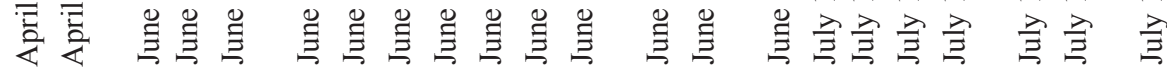

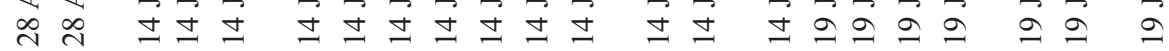

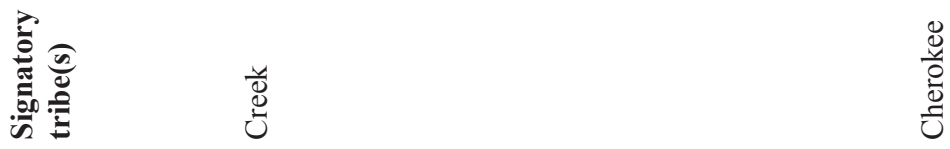

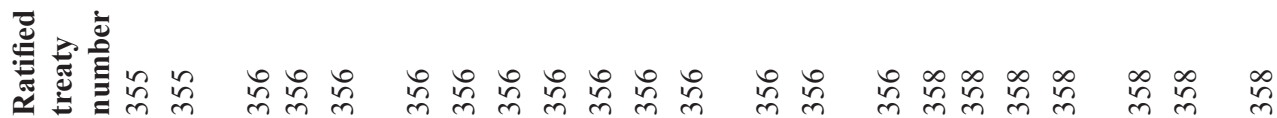




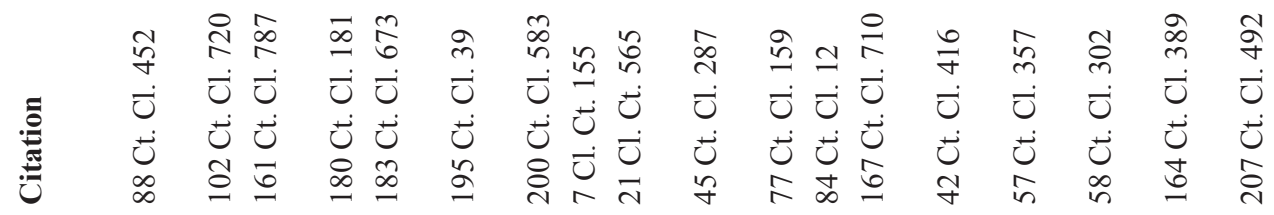

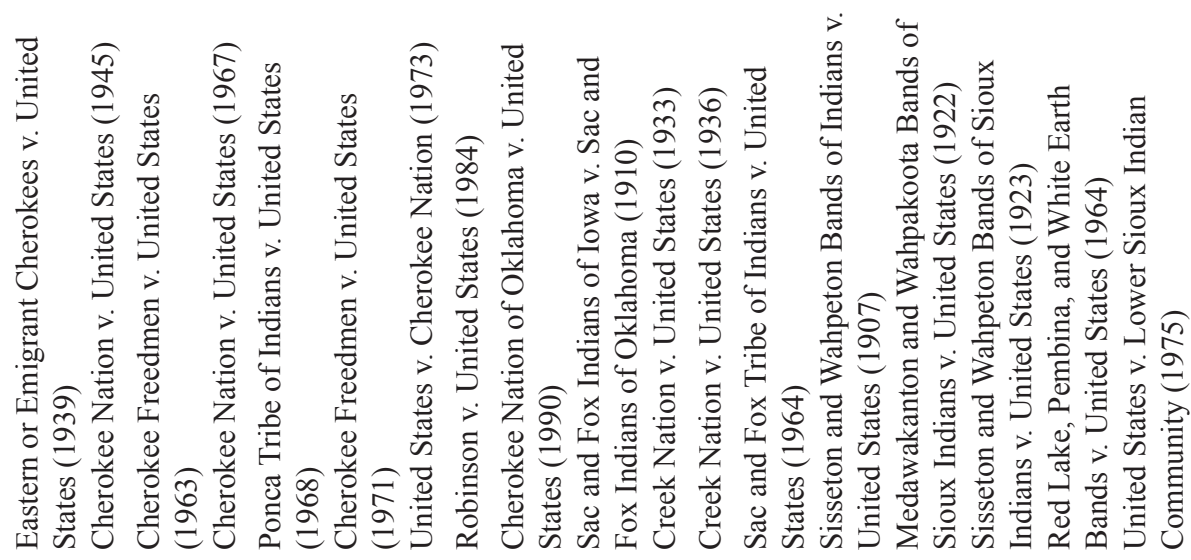

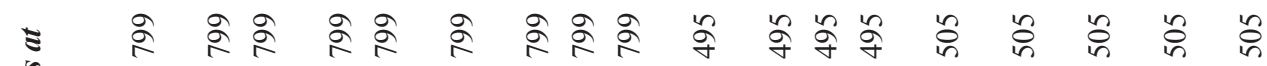

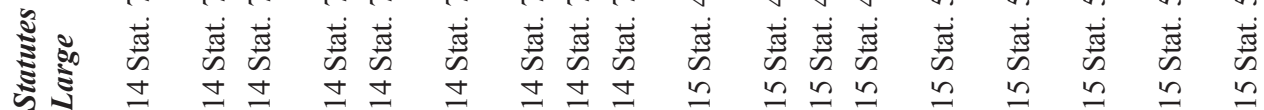

:

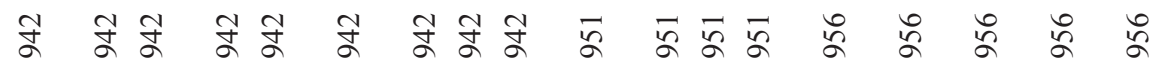
䒿

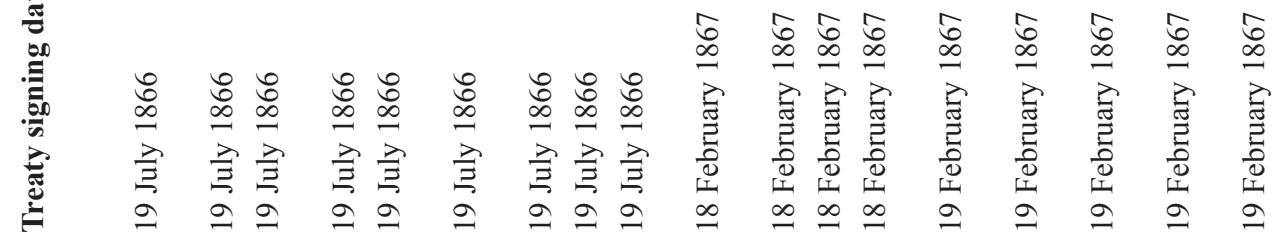
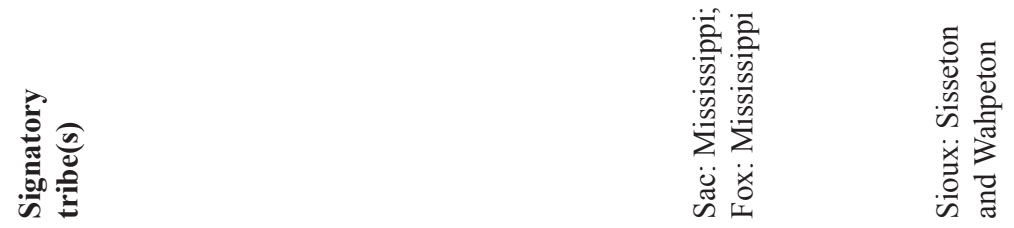

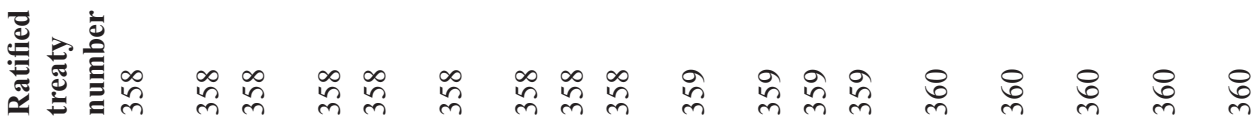




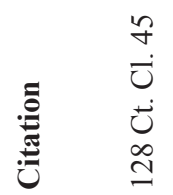

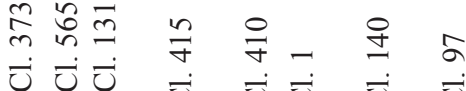

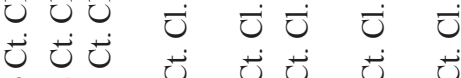

艺守等

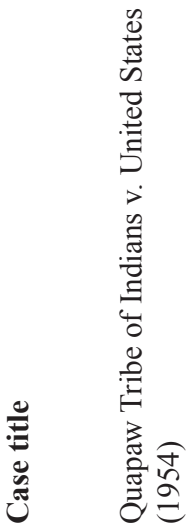

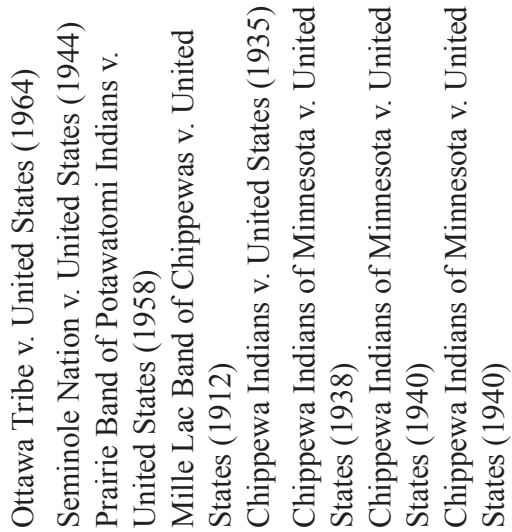

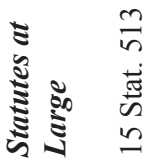

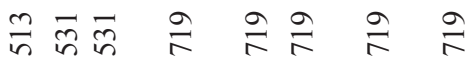

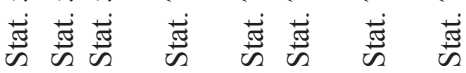

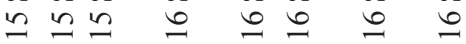

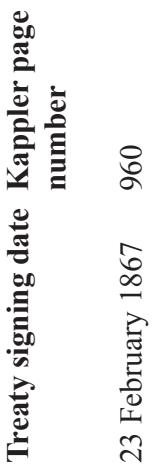

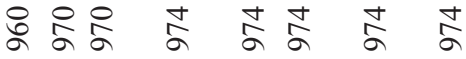

$\hat{\sigma} \hat{\varnothing} \hat{\circ}$

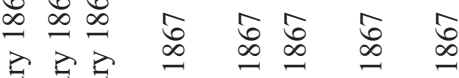

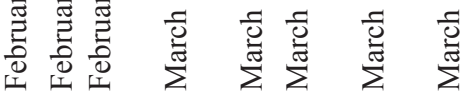

กㅅำ

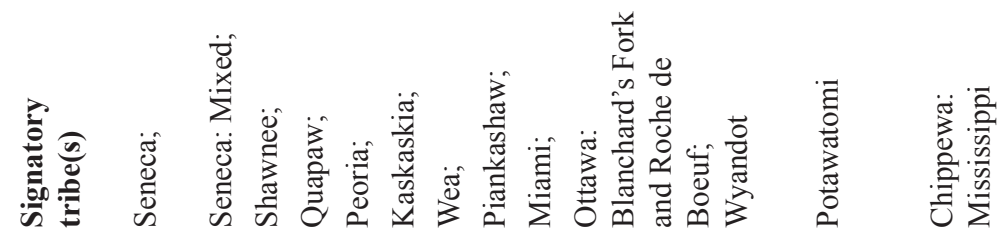




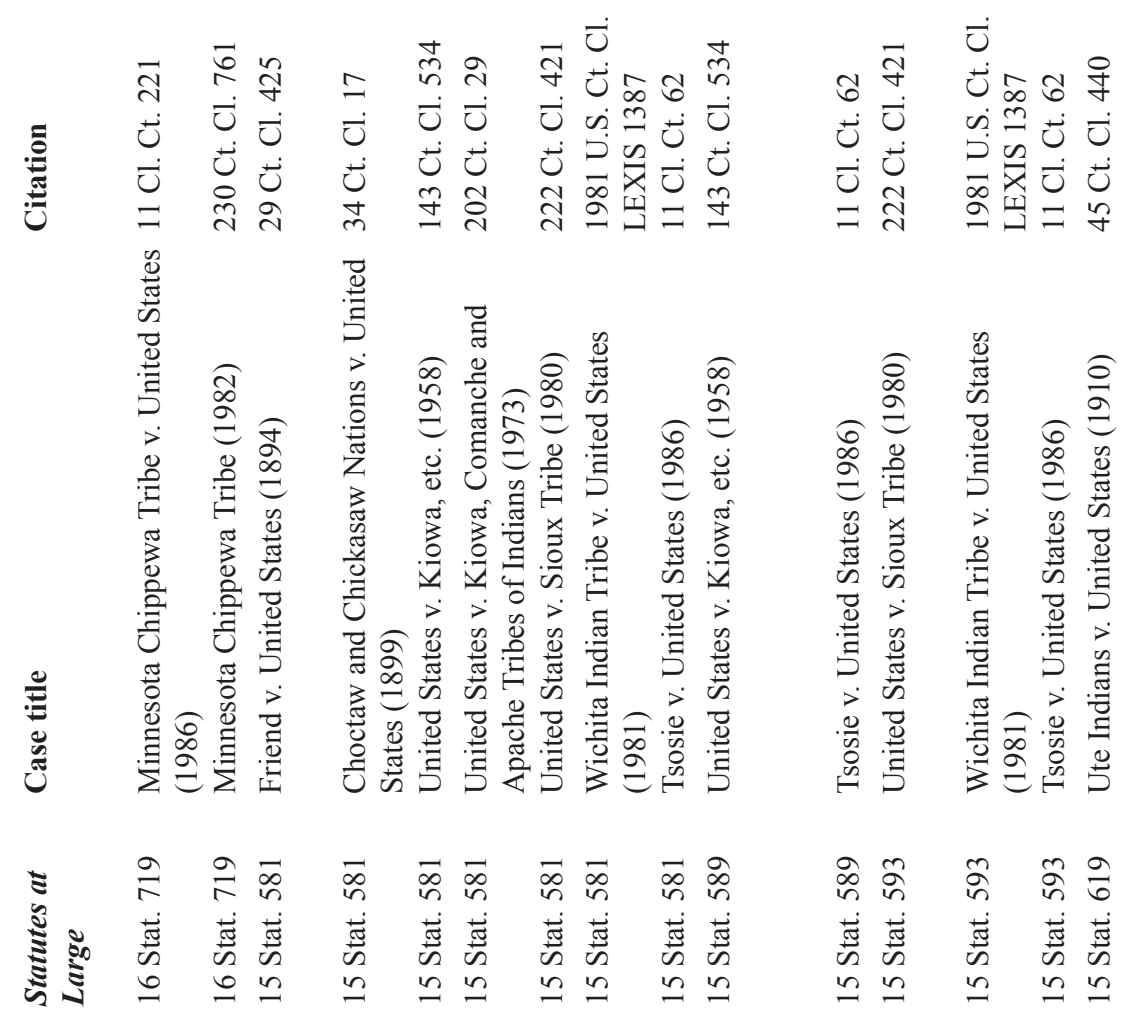

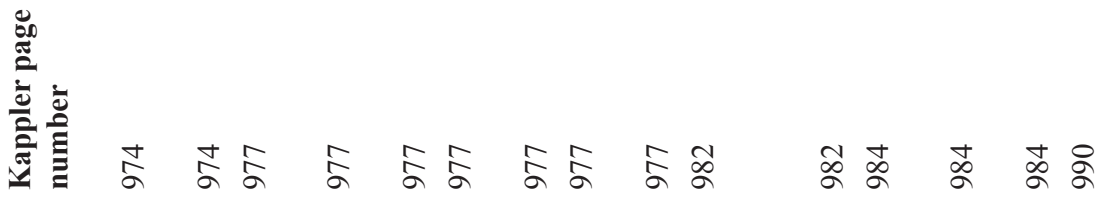

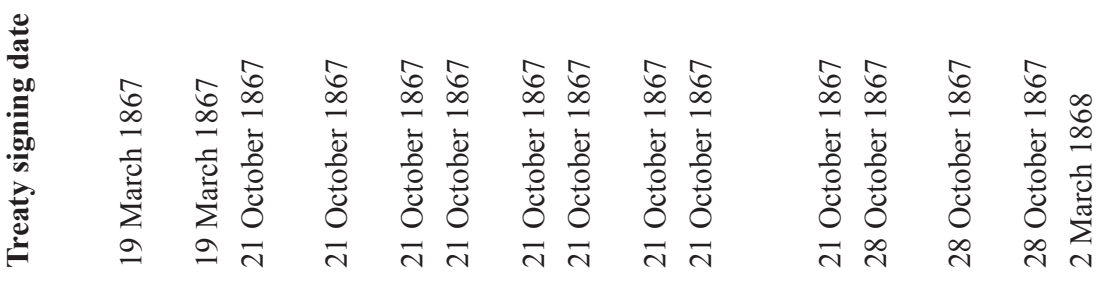

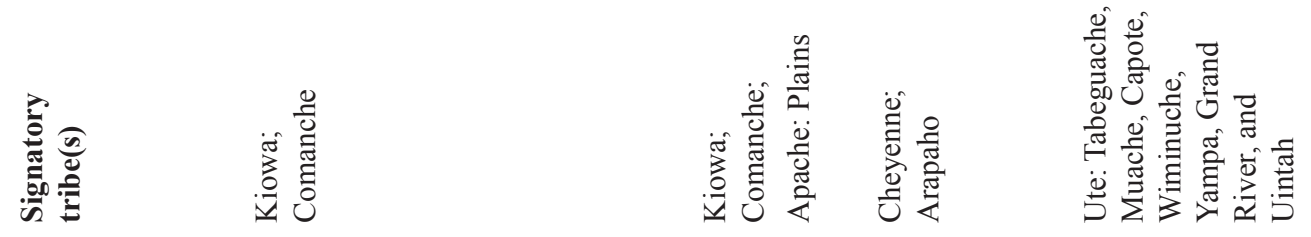

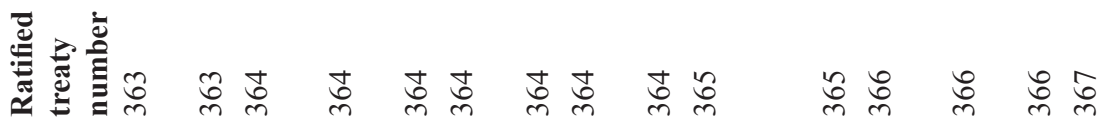




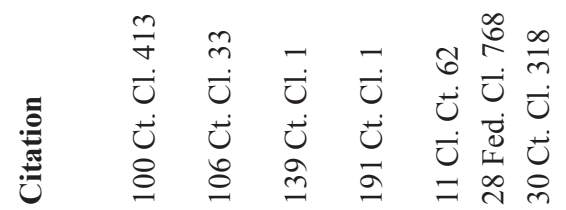

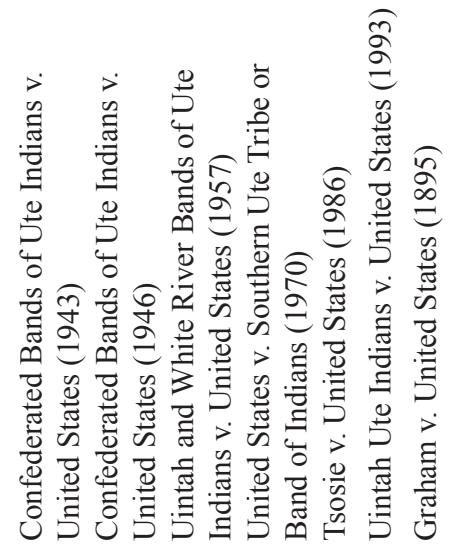

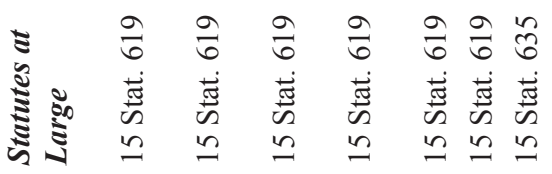

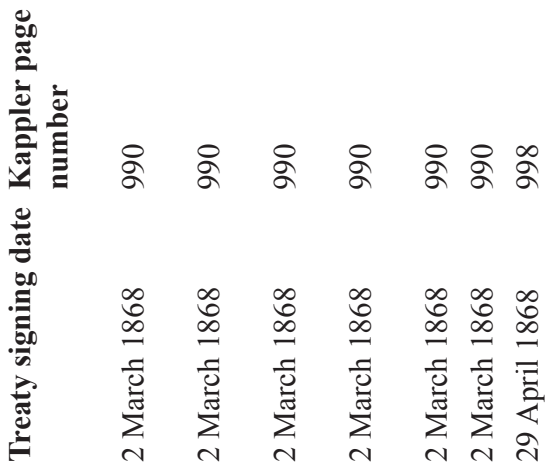

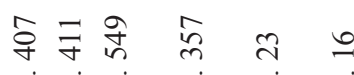

$\dot{U} \dot{U} \dot{U} \quad \dot{U} \quad \dot{U} \quad \dot{U}$

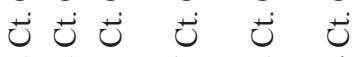

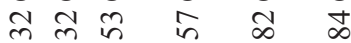

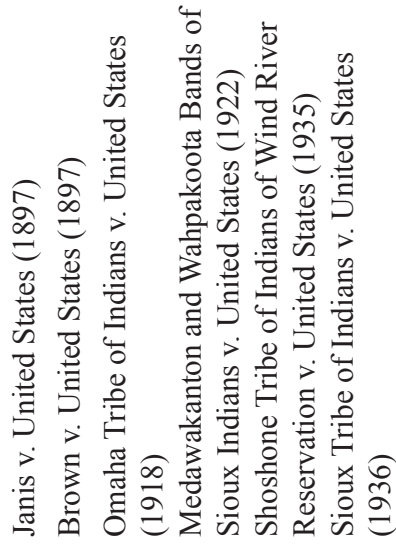

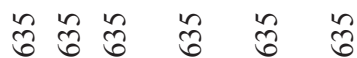

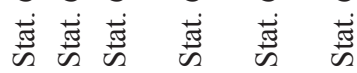
in $n$ in $n$
类各各

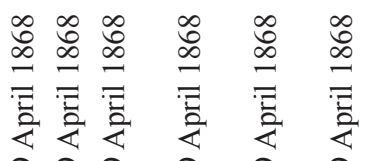

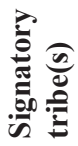

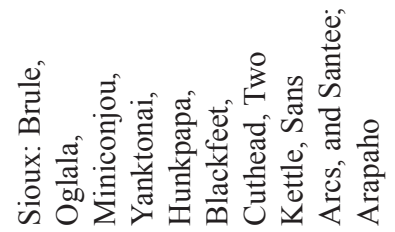

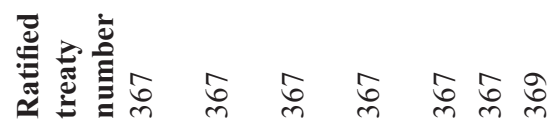

के పे రి 


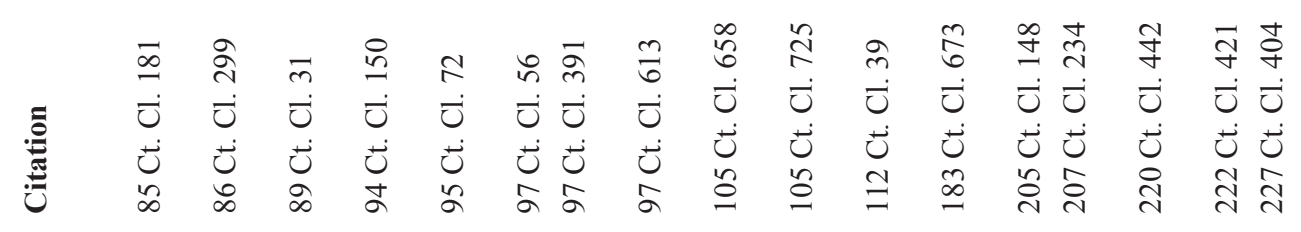

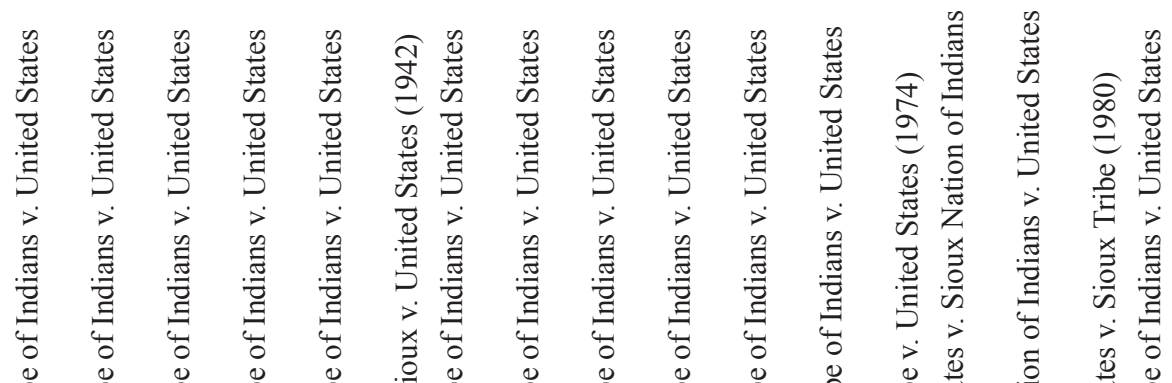

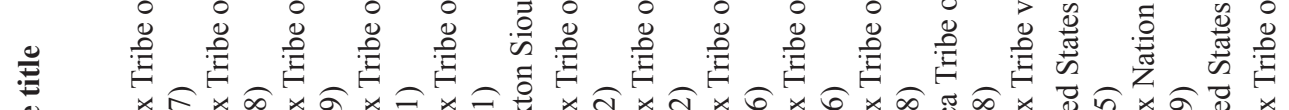

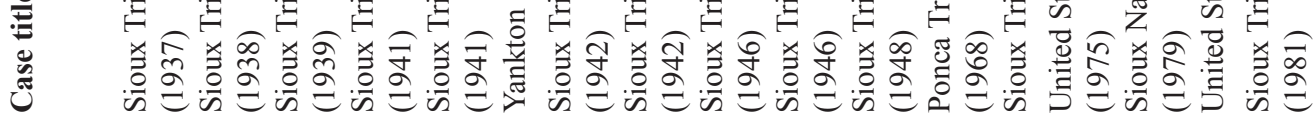

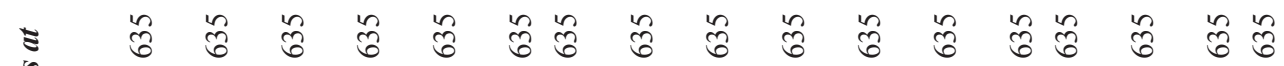

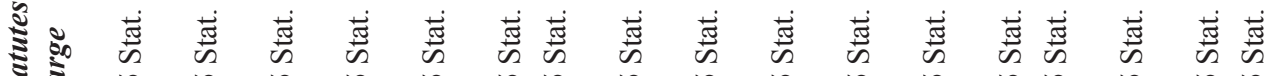

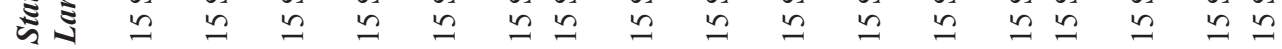
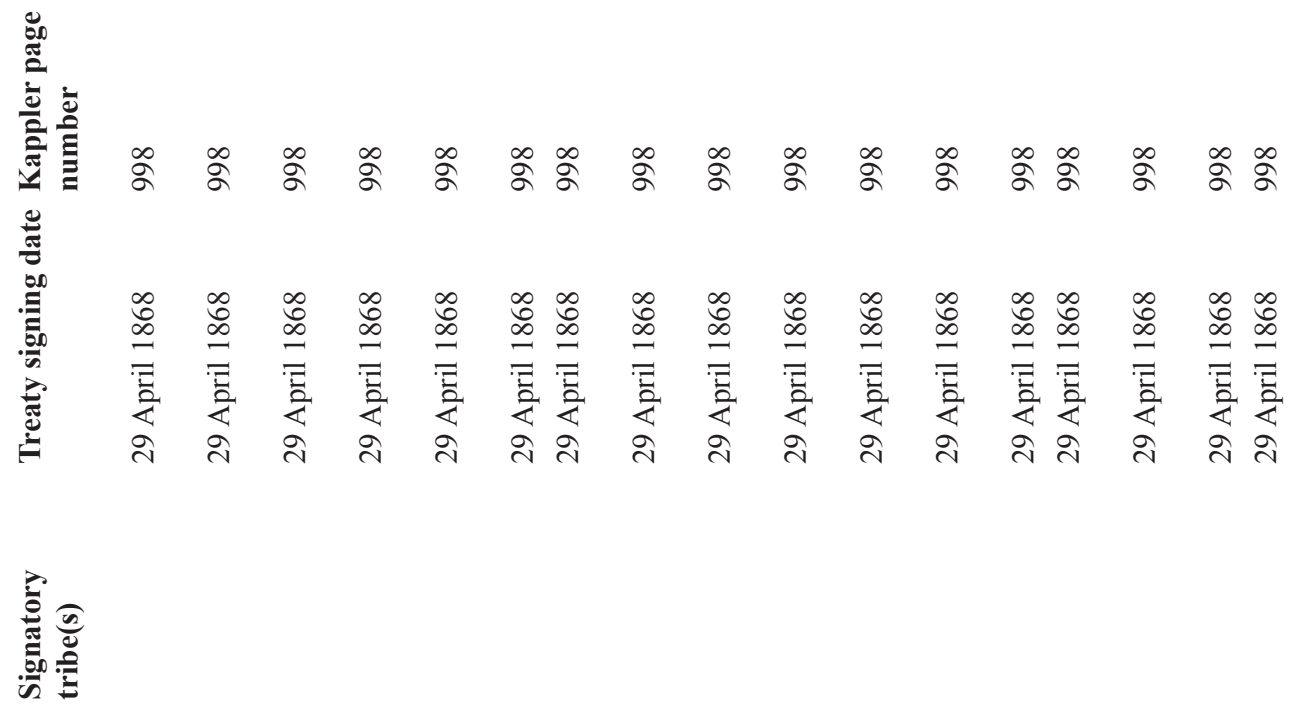

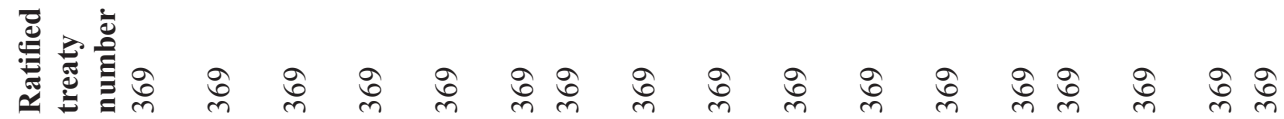




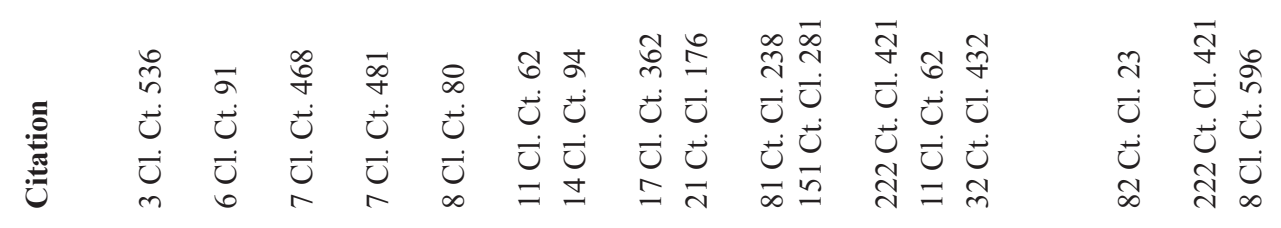

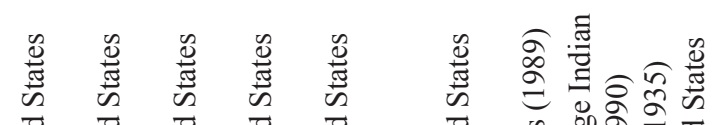

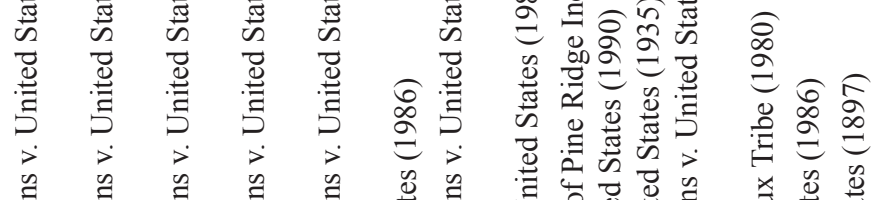

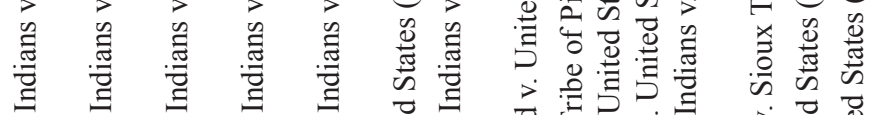

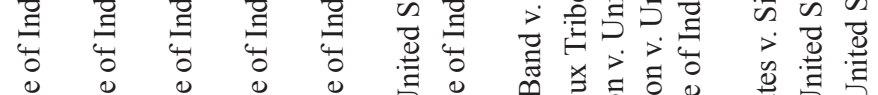

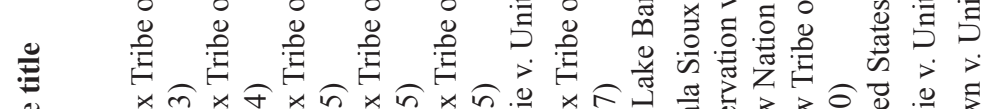

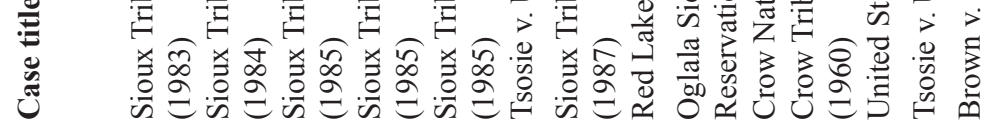

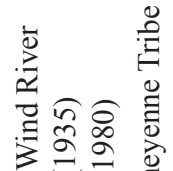

3.

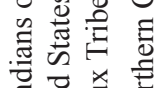

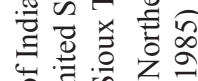

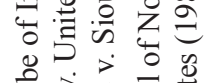

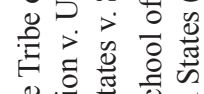

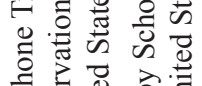

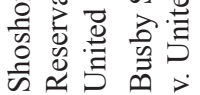

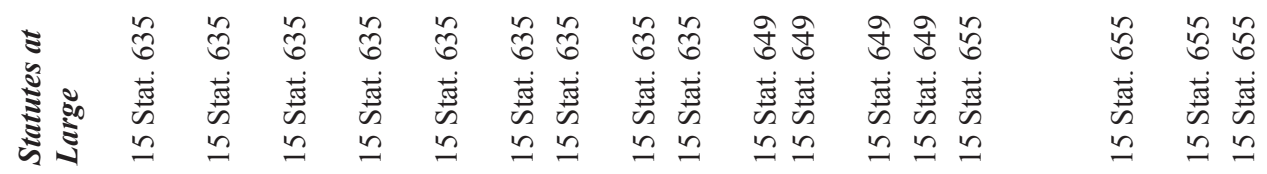

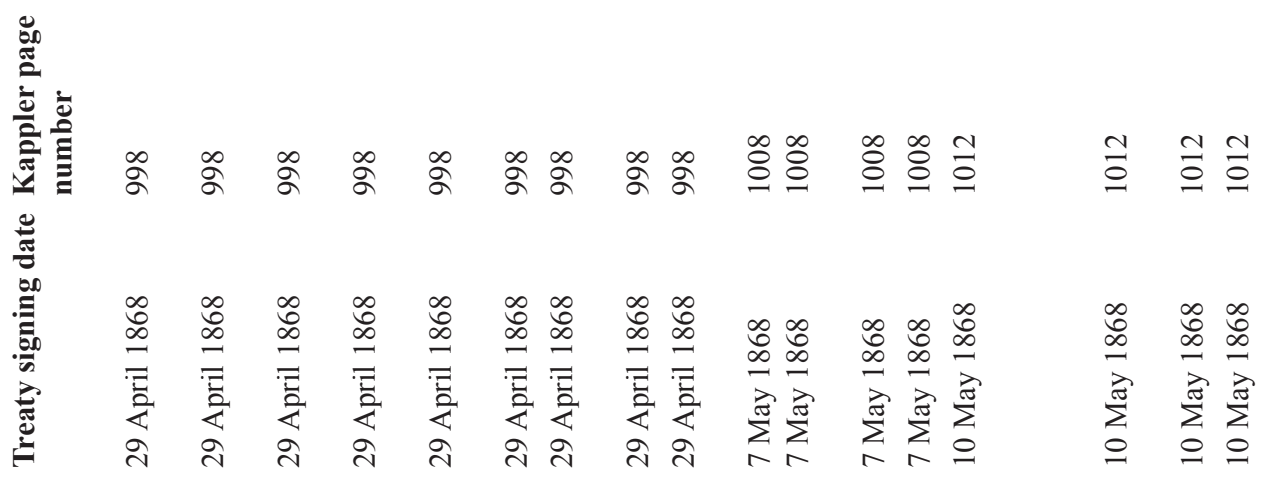

噌

兽言总产

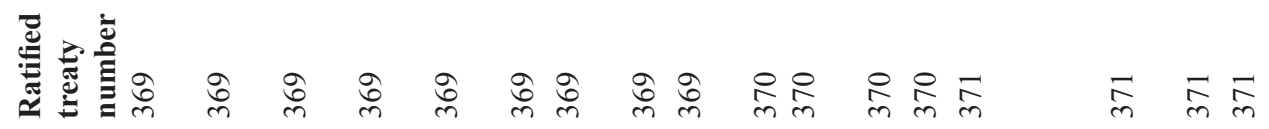



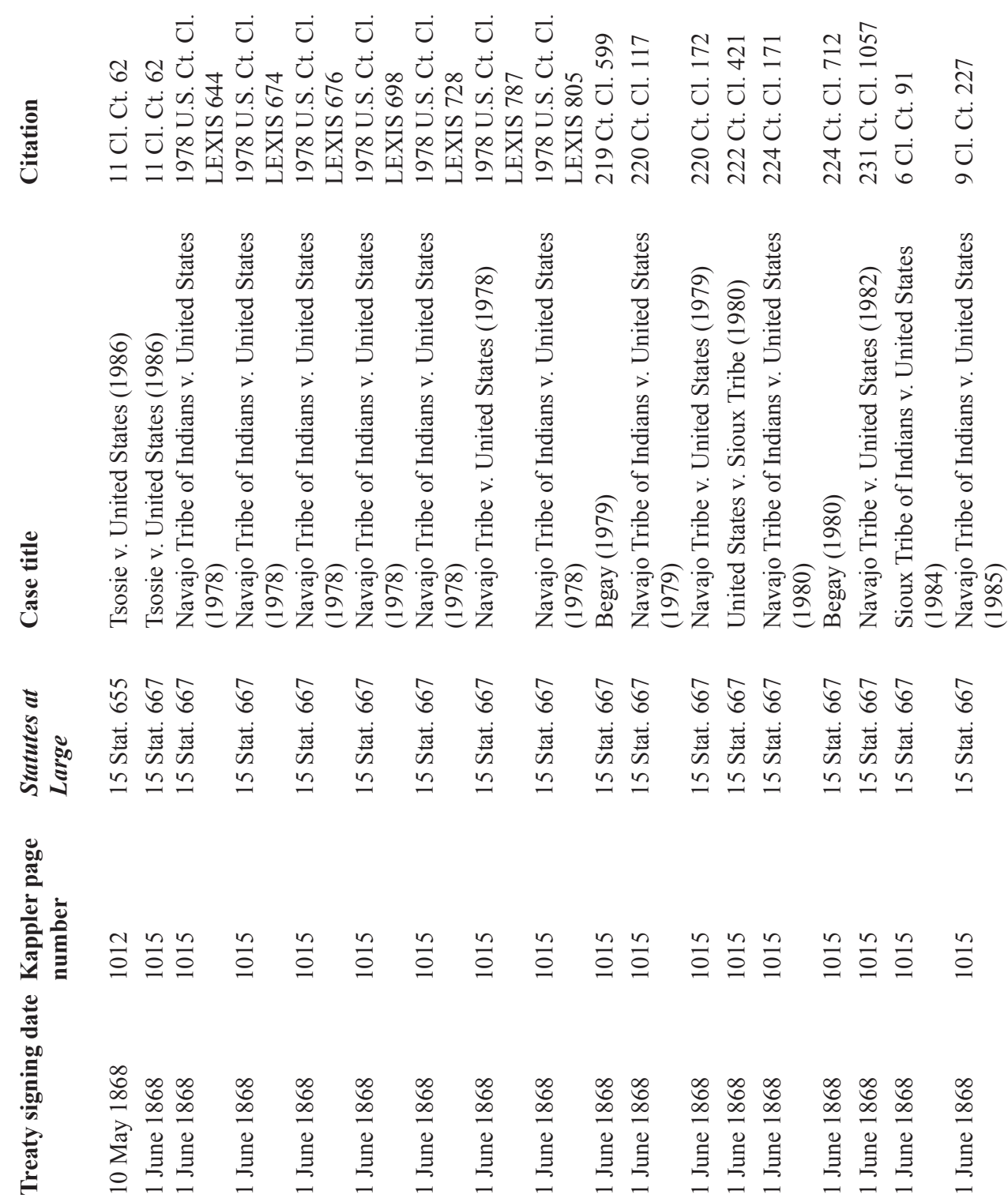

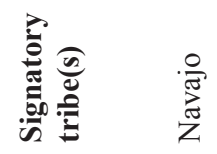

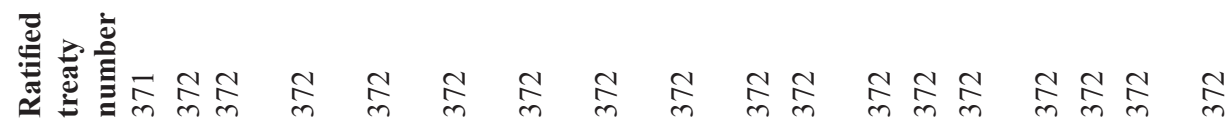




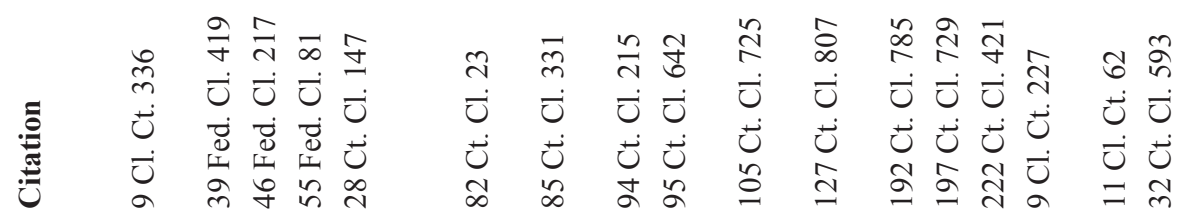

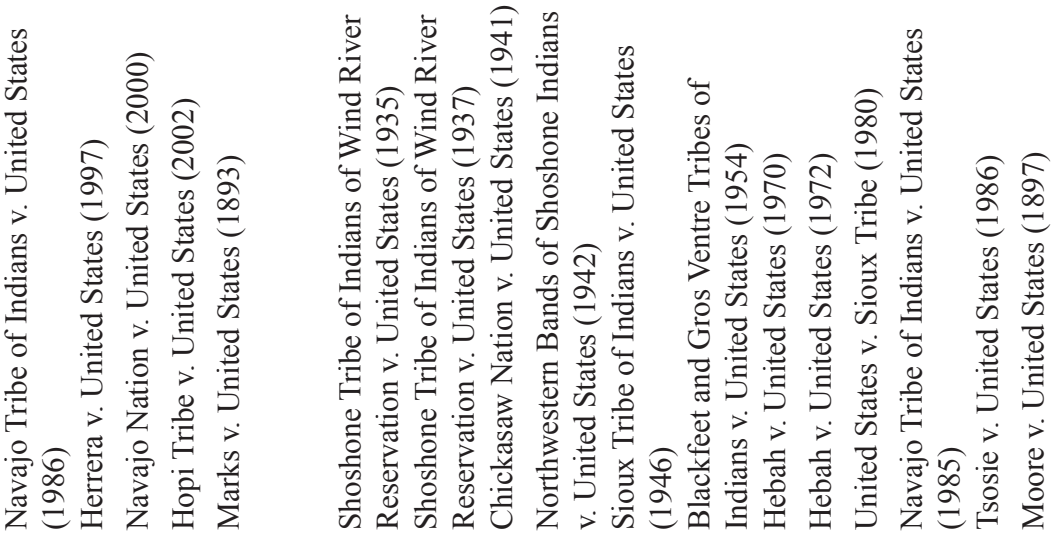

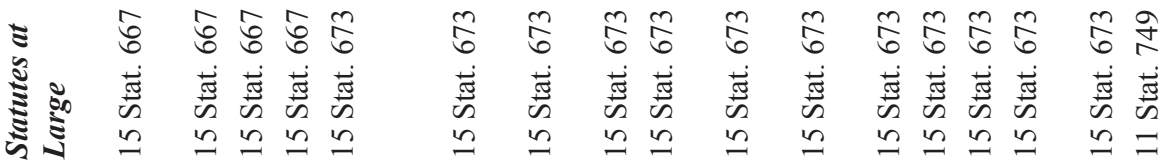

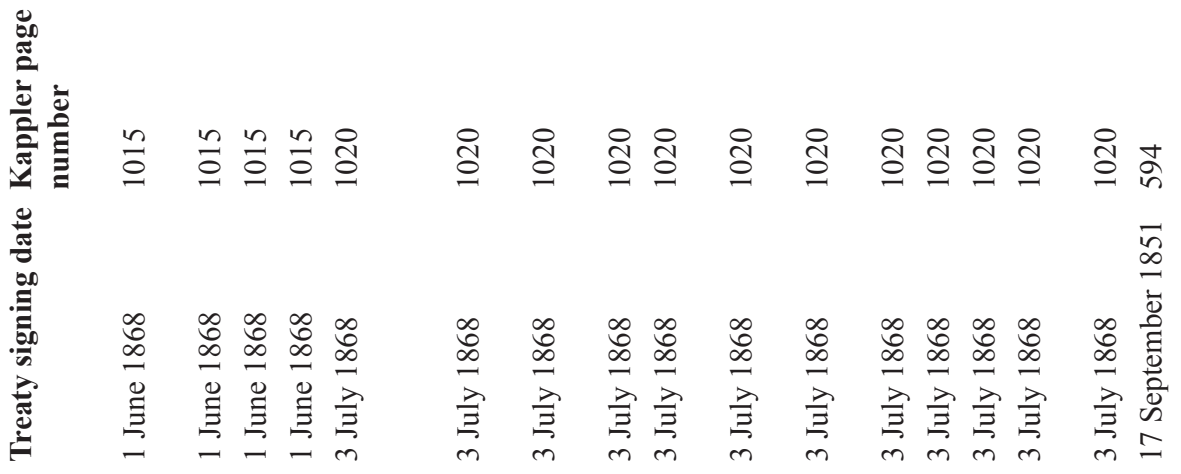

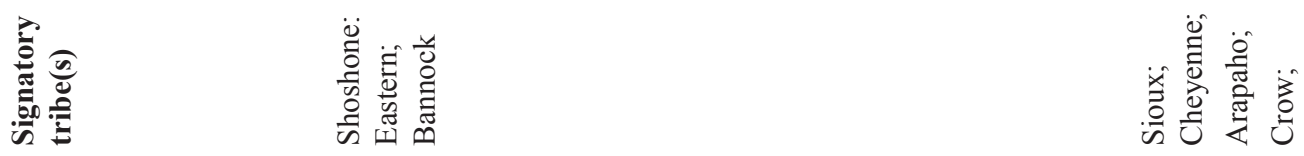

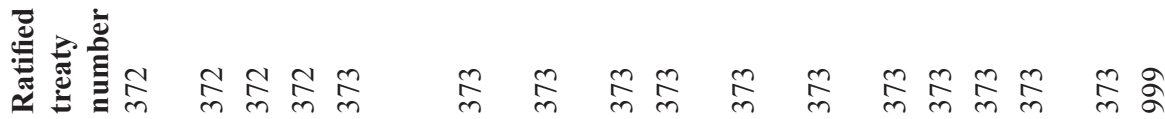


:

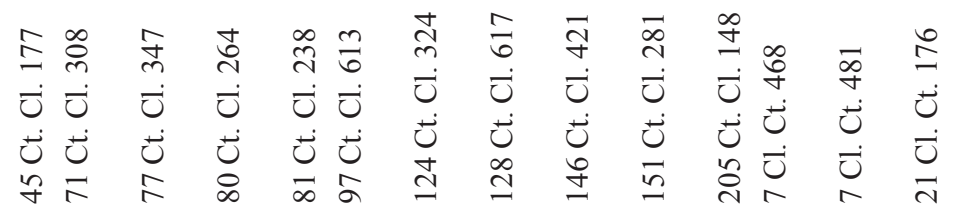

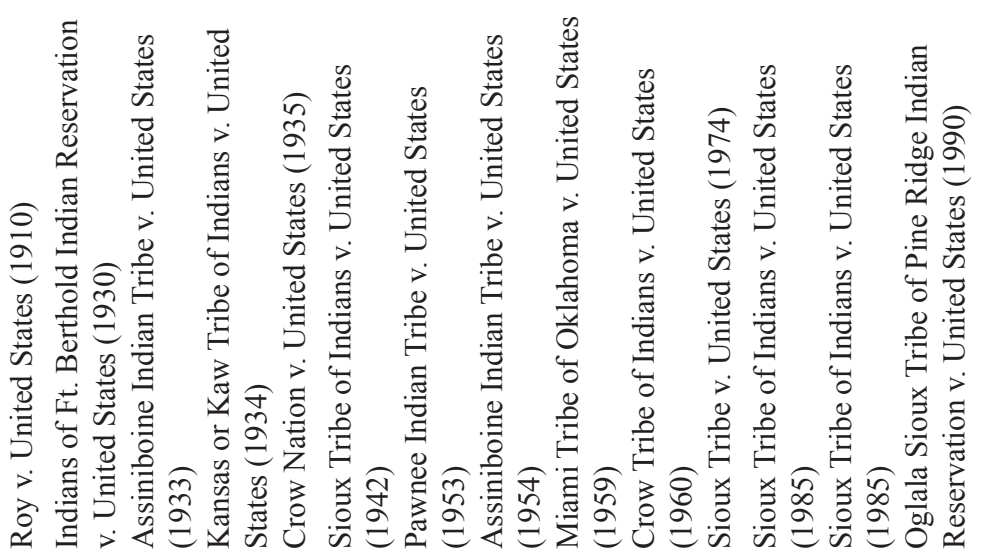

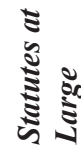

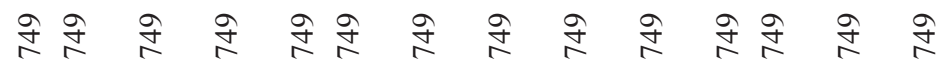

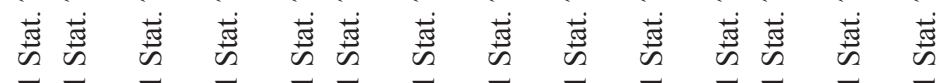

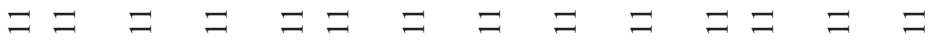

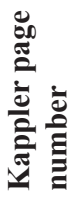

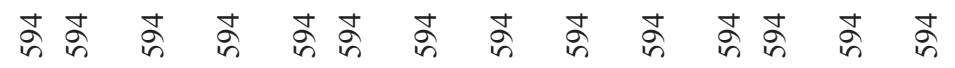

产

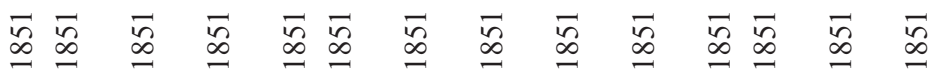

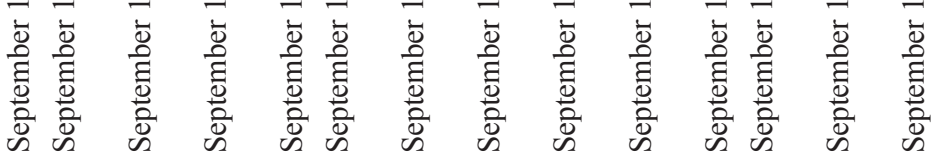

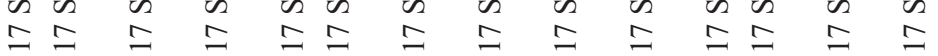

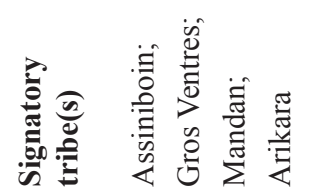

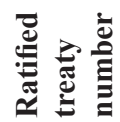

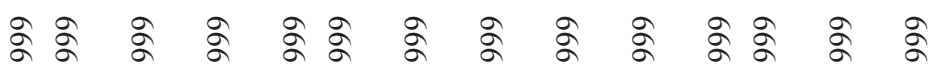

